U.S. Department of the Interior Southeast Climate Science Center

\title{
Insular Ecosystems of the Southeastern United States: A Regional Synthesis to Support Biodiversity Conservation in a Changing Climate
}
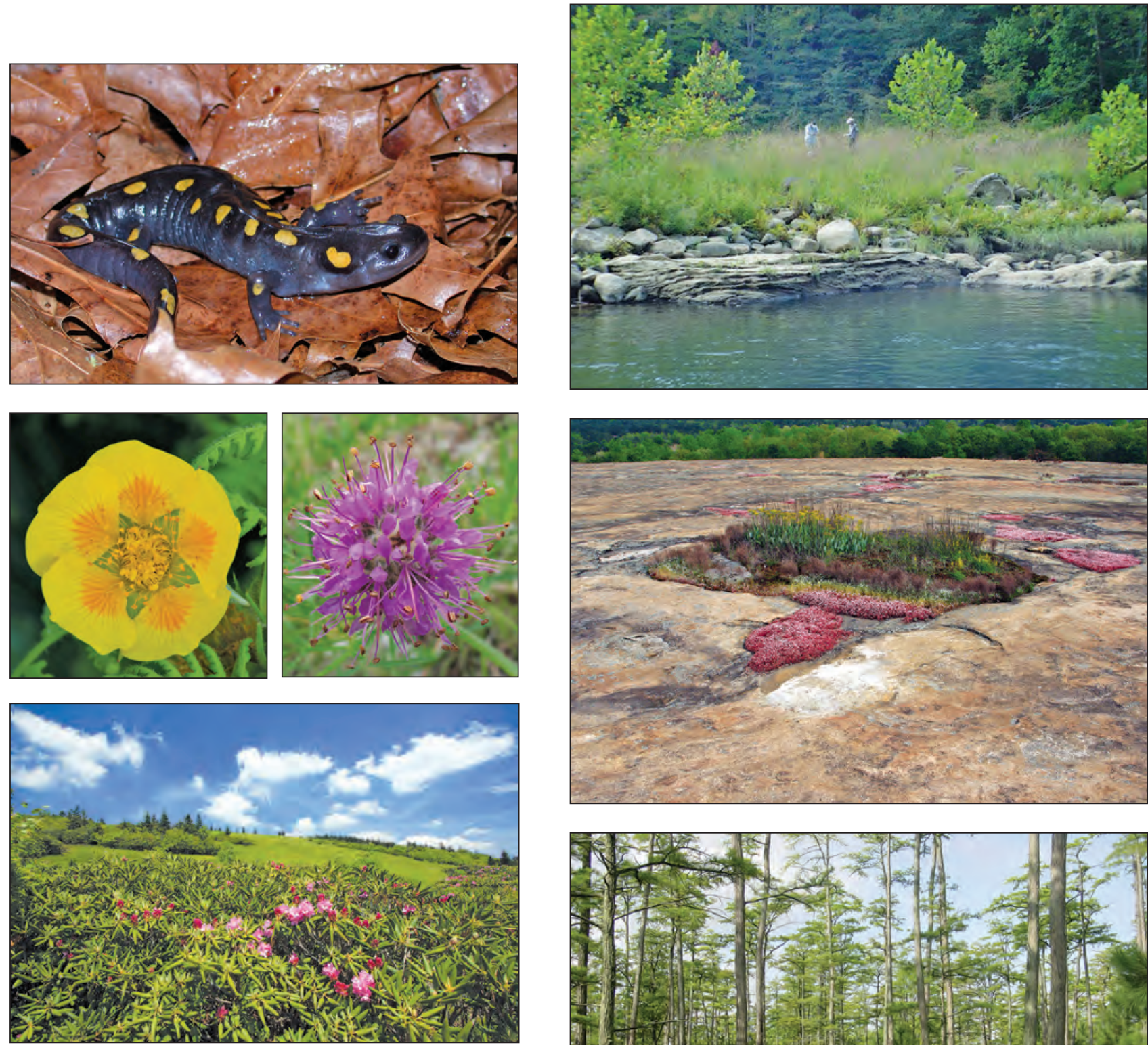

Professional Paper 1828

U.S. Department of the Interior U.S. Geological Survey

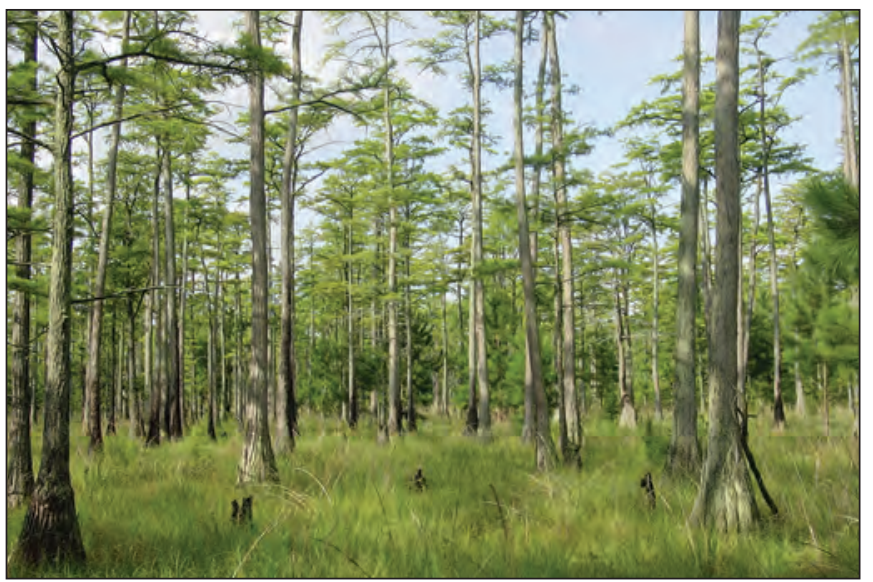




\section{Cover photographs, left column, top to bottom:}

Photographs are by Alan M. Cressler, U.S. Geological Survey, unless noted otherwise.

Ambystoma maculatum (spotted salamander) in a Carolina bay on the eastern shore of Maryland. Photograph by Joel Snodgrass, Virginia Polytechnic Institute and State University.

Geum radiatum, Roan Mountain, Pisgah National Forest, Mitchell County, North Carolina.

Dalea gattingeri, Chickamauga and Chattanooga National Military Park, Catoosa County, Georgia.

Round Bald, Pisgah and Cherokee National Forests, Mitchell County, North Carolina, and Carter County, Tennessee.

\section{Cover photographs, right column, top to bottom:}

Habitat monitoring at Leatherwood Ford cobble bar, Big South Fork Cumberland River, Big South Fork National River and Recreation Area, Tennessee. Photograph by Nora Murdock, National Park Service.

Soil island, Davidson-Arabia Mountain Nature Preserve, Dekalb County, Georgia. Photograph by Alan M. Cressler, U.S. Geological Survey.

Antioch Bay, Hoke County, North Carolina. Photograph by Lisa Kelly, University of North Carolina at Pembroke. 


\section{Insular Ecosystems of the Southeastern United States: A Regional Synthesis to Support Biodiversity Conservation in a Changing Climate}

By Jennifer M. Cartwright and William J. Wolfe

U.S. Department of the Interior Southeast Climate Science Center

Professional Paper 1828 


\title{
U.S. Department of the Interior SALLY JEWELL, Secretary
}

\section{U.S. Geological Survey Suzette M. Kimball, Director}

\author{
U.S. Geological Survey, Reston, Virginia: 2016
}

For more information on the USGS - the Federal source for science about the Earth, its natural and living resources, natural hazards, and the environment—visit http://www.usgs.gov or call 1-888-ASK-USGS.

For an overview of USGS information products, including maps, imagery, and publications, visit http://store.usgs.gov.

Any use of trade, firm, or product names is for descriptive purposes only and does not imply endorsement by the U.S. Government.

Although this information product, for the most part, is in the public domain, it also may contain copyrighted materials as noted in the text. Permission to reproduce copyrighted items must be secured from the copyright owner.

Suggested citation:

Cartwright, J.M., and Wolfe, W.J., 2016, Insular ecosystems of the southeastern United States—A regional synthesis to support biodiversity conservation in a changing climate: U.S. Geological Survey Professional Paper 1828, 162 p., http://dx.doi.org/10.3133/pp1828.

http://catalog.loc.gov/

ISSN 1044-9612 (print)

ISSN 2330-7102 (online)

ISBN 978-1-4113-4067-1 


\section{Contents}

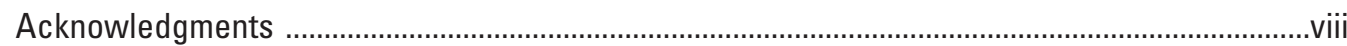

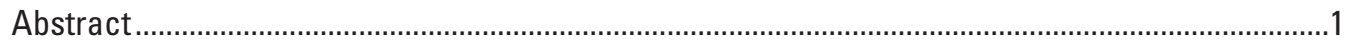

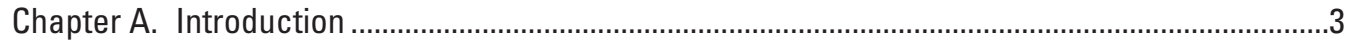

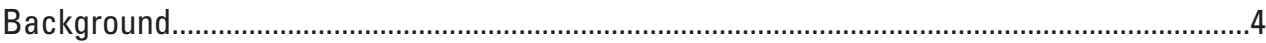

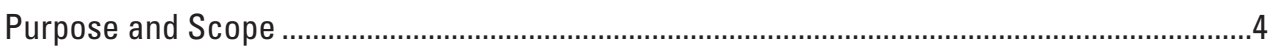

Approach

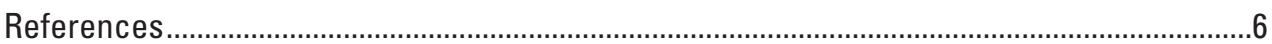

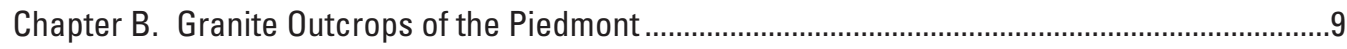

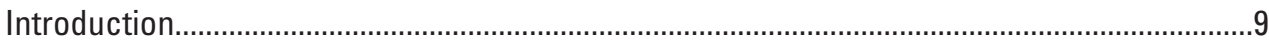

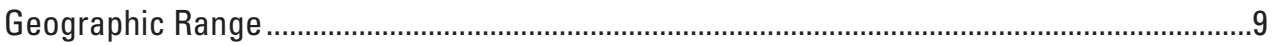

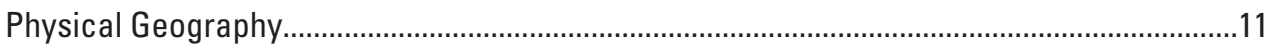

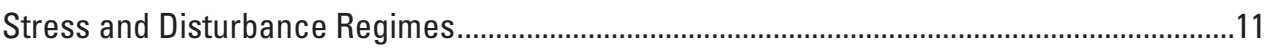

Community Types and Vegetation Dynamics ........................................................................12

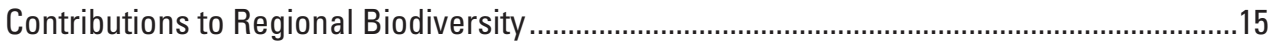

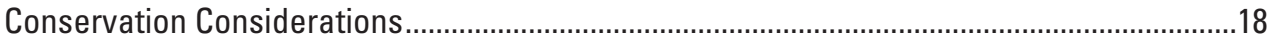

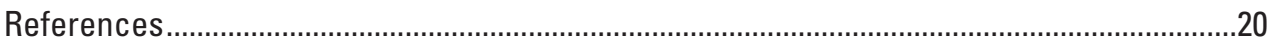

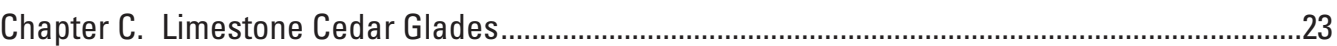

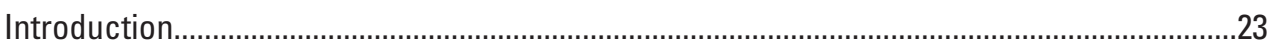

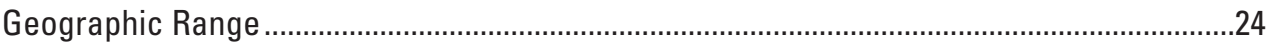

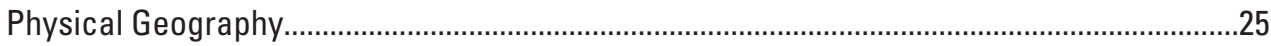

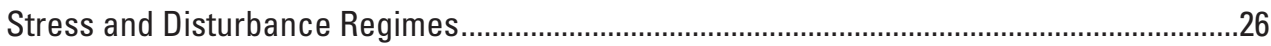

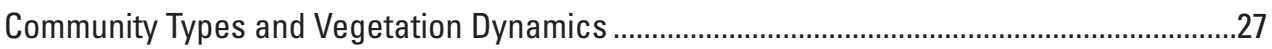

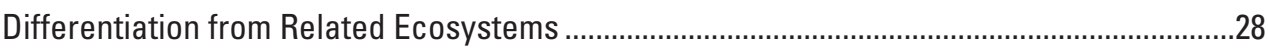

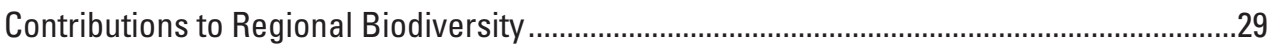

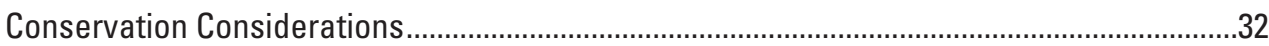

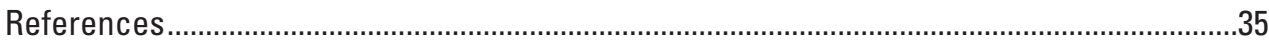

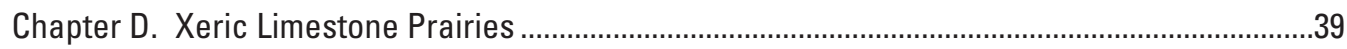

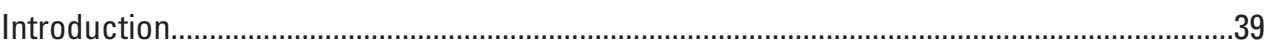

Geographic Range and Differentiation from Related Ecosystems .........................................39

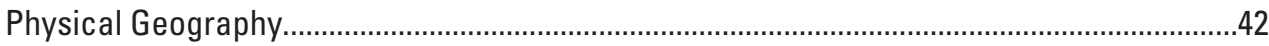

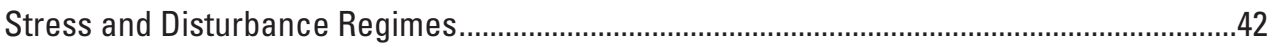

Community Types and Vegetation Dynamics ........................................................................4

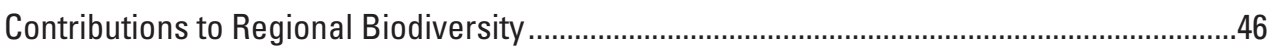

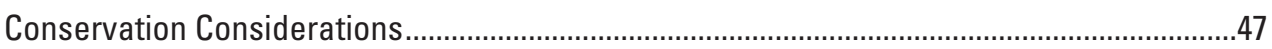

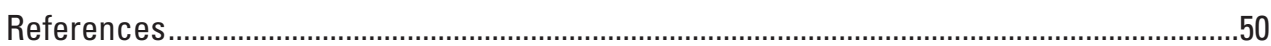

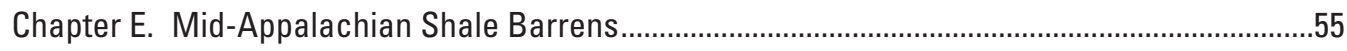

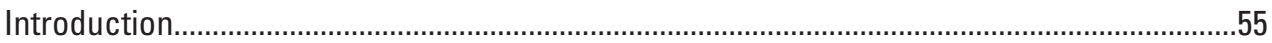

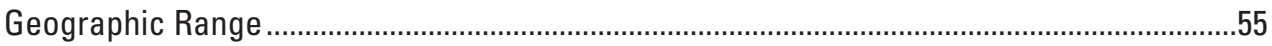

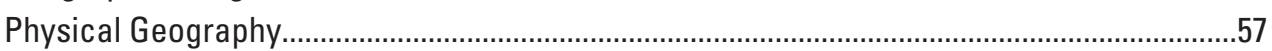

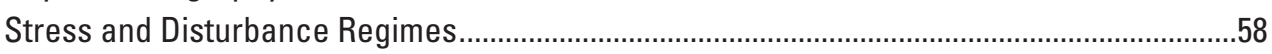

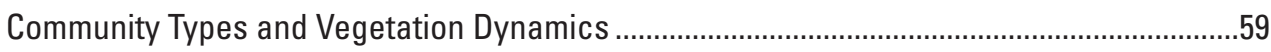

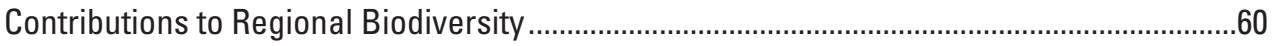

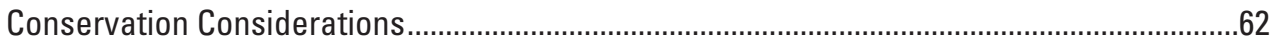

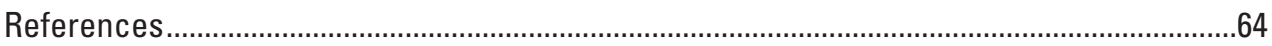


Chapter F. High-Elevation Outcrops and Balds of the Southern Appalachians .............................67

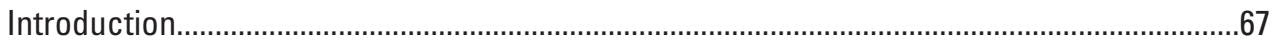

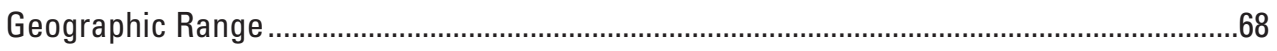

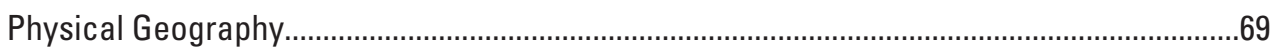

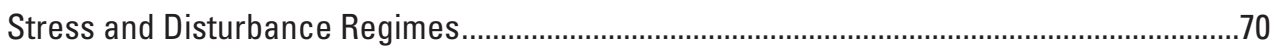

Community Types and Vegetation Dynamics ....................................................................72

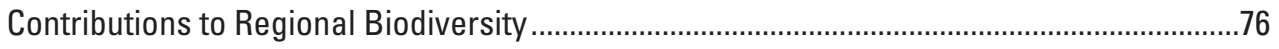

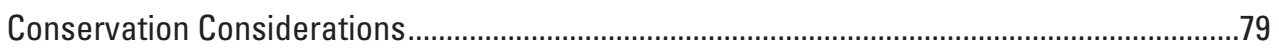

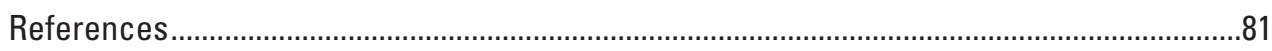

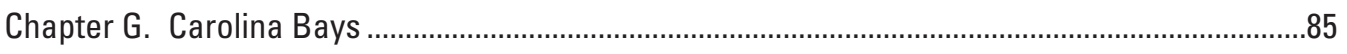

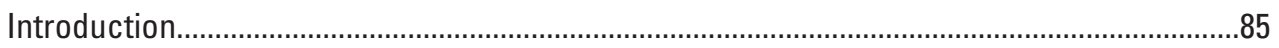

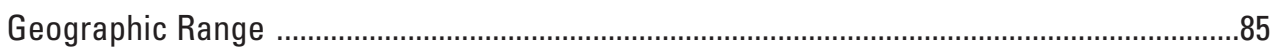

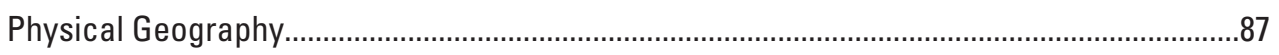

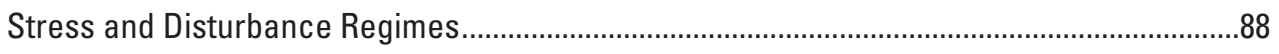

Community Types and Vegetation Dynamics ..................................................................90

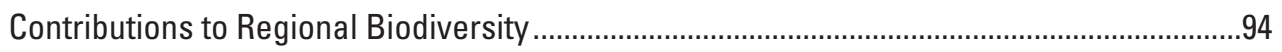

Conservation Considerations........................................................................................97

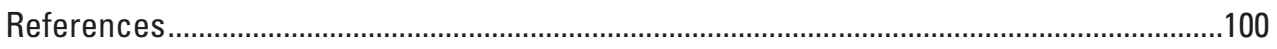

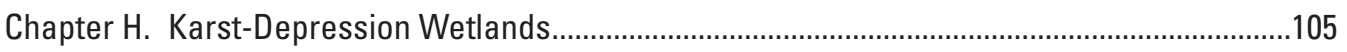

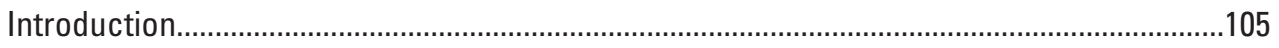

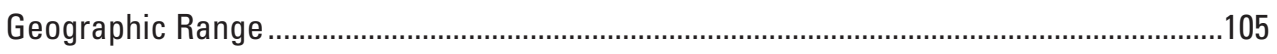

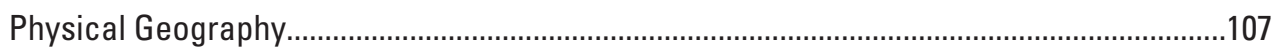

Stress and Disturbance Regimes................................................................................111

Community Types and Vegetation Dynamics .....................................................................113

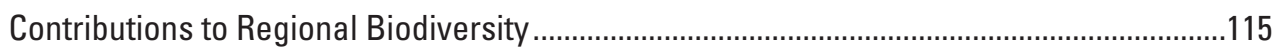

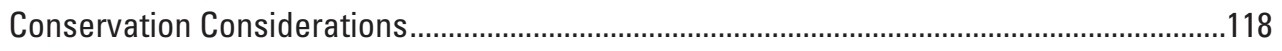

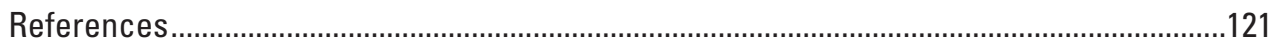

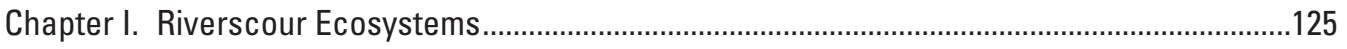

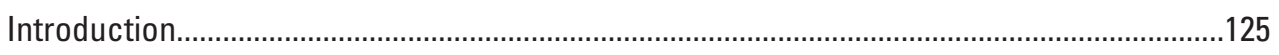

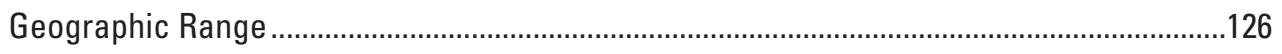

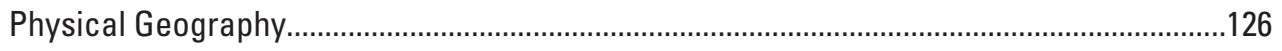

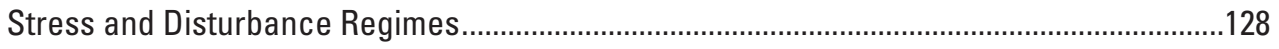

Community Types and Vegetation Dynamics ...................................................................129

Contributions to Regional Biodiversity ...........................................................................133

Conservation Considerations........................................................................................135

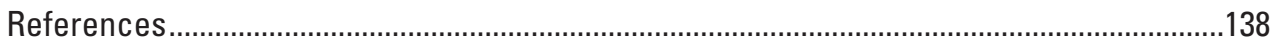

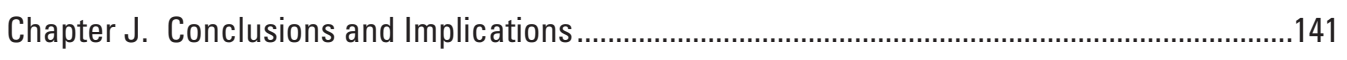

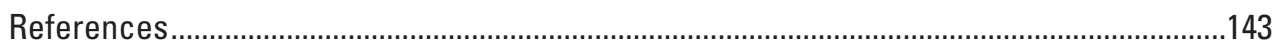

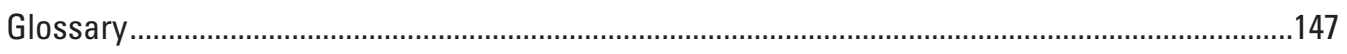

Appendix 1. Ecological System Names According to the International Terrestrial

Ecological Systems Classification ................................................................................149

Appendix 2. Component Associations According to the International Terrestrial Ecological Systems Classification ............................................................................. 150

Appendix 3. Selected Plant Taxa of Conservation Concern in Insular Ecosystems

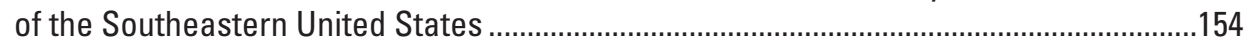

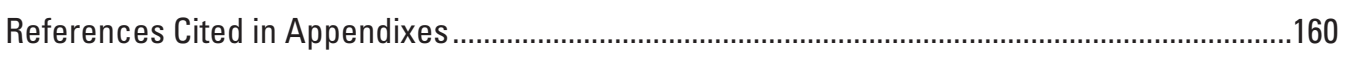




\section{Figures [All are photographs unless noted otherwise]}

B-1. Camp Meeting Rock Preserve, Heard County, Georgia .................................................. 9

B-2. Map showing geographic distribution of Piedmont granite outcrops ..............................10

B-3. Solution pits in a granite outcrop, Davidson-Arabia Mountain Nature Preserve, Dekalb County, Georgia ................................................................................................11

B-4. Moss-colonized rock surface, Davidson-Arabia Mountain Nature Preserve, Dekalb County, Georgia ..............................................................................................13

B-5. Soil island, Davidson-Arabia Mountain Nature Preserve, Dekalb County, Georgia ......14

B-6. Characteristic plant taxa of Piedmont granite outcrops..................................................17

C-1. Cedar Glade Number 5, Chickamauga and Chattanooga National Military Park,

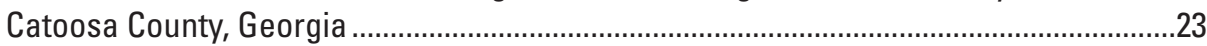

C-2. Map showing general geographic distribution of limestone cedar glades ...................24

C-3. Grass-filled cross joint, Chickamauga and Chattanooga National Military Park, Catoosa County, Georgia ...............................................................................................

C-4. Standing water, Flat Rock Cedar Glades and Barrens State Natural Area, Rutherford County, Tennessee

C-5. Characteristic plant taxa of limestone cedar glades ......................................................31

D-1. Grand Prairie, Coosa Valley Prairies, Floyd County, Georgia ...........................................39

D-2. Map showing general geographic distribution of xeric limestone prairies ....................40

D-3. Ketona dolomite glade, Kathy Stiles Freeland Bibb County Glades Preserve, Bibb County, Alabama

D-4. Dry Prairie, Coosa Valley Prairies, Floyd County, Georgia ................................................44

D-5. Rare plant taxa in Ketona dolomite glades at the Kathy Stiles Freeland Bibb County Glades Preserve, Bibb County, Alabama .....................................................4

E-1. Shale barren above a cowpasture, Bath County, Virginia .............................................55

E-2. Map showing general geographic distribution of mid-Appalachian shale barrens ......56

E-3. Shale barren, Edinburg Gap, George Washington and Jefferson National Forests, Shenandoah County, Virginia..........................................................................................57

E-4. Shale barren undercut by a stream, Bath County, Virginia ..............................................58

E-5. Characteristic plant taxa of mid-Appalachian shale barrens .........................................61

F-1. Round Bald, Pisgah and Cherokee National Forests, Mitchell County, North Carolina, and Carter County, Tennessee

F-2. Map showing geographic distribution of high-elevation outcrops and balds in the southern Appalachians

F-3. Grass bald and heath bald mosaic at Round Bald, Pisgah and Cherokee National Forests, Mitchell County, North Carolina, and Carter County, Tennessee .......................73

F-4. Grass bald at Round Bald, Pisgah and Cherokee National Forests, Mitchell County, North Carolina, and Carter County, Tennessee .

F-5. Rock outcrop at Sassafrass Mountain, Nantahala National Forest, Jackson County, North Carolina

F-6. High-elevation rock outcrop community, Craggy Dome, Blue Ridge Parkway, Buncombe County, North Carolina .

F-7. Characteristic taxa of high-elevation outcrops and balds 
G-1. Aerial view of Dry Bay, Savannah River National Environmental

Research Park, South Carolina

G-2. Map showing regions of concentrated occurrence of Carolina bays ...........................86

G-3. A Carolina bay at Francis Marion National Forest, South Carolina ...................................89

G-4. Burned pocosin vegetation, Pocosin Lakes National Wildlife Refuge,

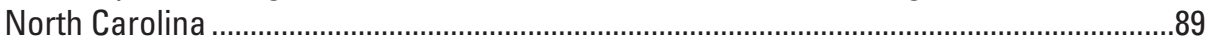

G-5. Seventeen Frog Pond, Scotland County, North Carolina …............................................90

G-6. Antioch Bay, Hoke County, North Carolina ....................................................................91

G-7. Hamby's Bay, Hoke County, North Carolina ..............................................................91

G-8. Pocosin vegetation, Pocosin Lakes National Wildlife Refuge, North Carolina................93

G-9. Diagram showing relationship between Carolina bays and pocosins ............................93

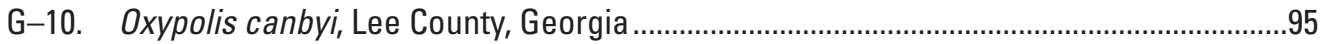

G-11. Amphibian taxa supported by Carolina bay habitat......................................................96

H-1. Harriston Ponds, Augusta County, Virginia ................................................................105

$\mathrm{H}-2$. Map showing general geographic distribution of selected areas containing concentrations of karst-depression wetlands in the southeastern United States........106

H-3. Nyssa aquatica stand in Westall Swamp, Arnold Air Force Base, Coffee County, Tennessee..............................................................................................108

H-4. Deep Pond, Maple Flats Pond Complex, Augusta County, Virginia................................109

H-5. Deep Run Ponds, Rockingham County, Virginia .........................................................110

H-6. Two views of Sinking Pond, Arnold Air Force Base, Coffee County, Tennessee: fully drained with leaves on in the summer, and fully drained with snow in

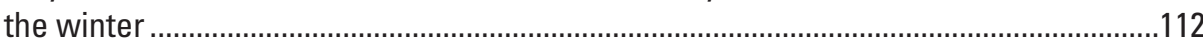

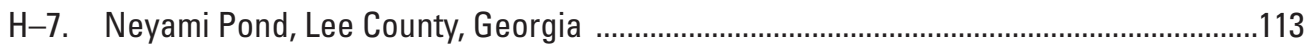

H-8. Davidson Run Pond, Rockbridge County, Virginia.........................................................115

H-9. Helenium virginicum at Twin Ponds, Maple Flats Pond Complex, Augusta County, Virginia 116

I-1. Rough Shoals, Big South Fork Cumberland River, Big South Fork National River and Recreation Area, Tennessee... 125

I-2. Map showing selected locations of riverscour ecosystems in the southeastern United States

I-3. Appalachian Riverside Flatrock Community, Sandstone Falls, New River, New River Gorge National River, Raleigh County, West Virginia

I-4. Bedrock outcrop exposures along the New River at Camp Brookside, New River Gorge National River, Summers County, West Virginia .

1-5. Rare taxa associated with riverscour habitat in the southeastern United States ........134

1-6. Habitat monitoring at Leatherwood Ford cobble bar, Big South Fork Cumberland River, Big South Fork National River and Recreation Area, Tennessee. 137

\section{Tables}

C-1. Factors differentiating limestone cedar glades from xeric limestone prairies................29

I-1. Selected streams supporting riverscour ecosystems within the southeastern United States

I-2. Selected occurrences of riverscour ecosystems on protected public land .................137

J-1. Examples of additional insular ecosystems in the southeastern United States ............141

$\mathrm{J}-2$. Examples of insular ecosystems outside the southeastern United States 


\section{Conversion Factors}

International System of Units to Inch/Pound

\begin{tabular}{lcl}
\hline \multicolumn{1}{c}{ Multiply } & By & \multicolumn{1}{c}{ To obtain } \\
\hline centimeter $(\mathrm{cm})$ & Length & inch (in.) \\
millimeter $(\mathrm{mm})$ & 0.3937 & inch (in.) \\
meter $(\mathrm{m})$ & 0.03937 & foot (ft) \\
kilometer $(\mathrm{km})$ & 3.281 & mile (mi) \\
kilometer $(\mathrm{km})$ & 0.6214 & mile, nautical $(\mathrm{nmi})$ \\
meter $(\mathrm{m})$ & 0.5400 & yard (yd) \\
\hline & 1.094 & \\
\hline hectare $($ ha) & Area & acre \\
square kilometer $\left(\mathrm{km}^{2}\right)$ & 2.471 & acre \\
hectare (ha) & 247.1 & square mile $\left(\mathrm{mi}^{2}\right)$ \\
square kilometer $\left(\mathrm{km}^{2}\right)$ & 0.003861 & square mile $\left(\mathrm{mi}^{2}\right)$ \\
\hline & 0.3861 & \\
\hline kilometer per hour $\left(\mathrm{km}^{2} \mathrm{~h}\right)$ & Flow rate & mile per hour $\left(\mathrm{mi}^{2} / \mathrm{h}\right)$ \\
\hline
\end{tabular}

Inch/Pound to International System of Units

\begin{tabular}{|c|c|c|}
\hline Multiply & By & To obtain \\
\hline \multicolumn{3}{|c|}{ Length } \\
\hline foot $(\mathrm{ft})$ & 0.3048 & meter $(\mathrm{m})$ \\
\hline mile (mi) & 1.609 & kilometer (km) \\
\hline \multicolumn{3}{|c|}{ Area } \\
\hline acre & 4,047 & square meter $\left(\mathrm{m}^{2}\right)$ \\
\hline acre & 0.4047 & hectare (ha) \\
\hline acre & 0.4047 & square hectometer $\left(\mathrm{hm}^{2}\right)$ \\
\hline acre & 0.004047 & square kilometer $\left(\mathrm{km}^{2}\right)$ \\
\hline square mile $\left(\mathrm{mi}^{2}\right)$ & 259.0 & hectare (ha) \\
\hline square mile $\left(\mathrm{mi}^{2}\right)$ & 2.590 & square kilometer $\left(\mathrm{km}^{2}\right)$ \\
\hline \multicolumn{3}{|c|}{ Flow rate } \\
\hline cubic foot per second $\left(\mathrm{ft}^{3} / \mathrm{s}\right)$ & 0.02832 & cubic meter per second ( \\
\hline
\end{tabular}

Temperature in degrees Celsius $\left({ }^{\circ} \mathrm{C}\right)$ may be converted to degrees Fahrenheit $\left({ }^{\circ} \mathrm{F}\right)$ as follows:

$$
{ }^{\circ} \mathrm{F}=\left(1.8 \times{ }^{\circ} \mathrm{C}\right)+32
$$

Horizontal coordinate information is referenced to the World Geodetic System of 1984 (WGS 84).

\section{Abbreviations}

ITESC International Terrestrial Ecological Systems Classification

USNVC U.S. National Vegetation Classification 


\section{Acknowledgments}

This literature synthesis was funded in part by the U.S. Department of the Interior Southeast Climate Science Center. The authors wish to acknowledge the guidance and collaboration of Jennifer Costanza and Jaime Collazo at North Carolina State University and Milo Pyne at NatureServe.

The authors are grateful to the following colleagues for providing technical reviews of the draft report chapters and tables: Mason Brock, ${ }^{1}$ Jennifer Costanza, ${ }^{2}$ Diane DeSteven, ${ }^{3}$ Timothy Diehl, ${ }^{4}$ Glenn Guntenspergen, ${ }^{4}$ Benjamin Miller, ${ }^{4}$ Donald Phillips, ${ }^{5}$ Milo Pyne ${ }_{,}^{6}$ Devin Rodgers, ${ }_{1}$ Joel Snodgrass, ${ }^{7}$ Jeffrey Walck, ${ }^{8}$ Thomas Wentworth, ${ }^{2}$ Peter White, ${ }_{1}^{9}$ Thomas Wieboldt, Susan Wiser, ${ }^{10}$ Theo Witsell, ${ }^{11}$ and James Vanderhorst. ${ }^{12}$ The authors also wish to thank James Petersen, ${ }^{4}$ Caitlin Elam, ${ }^{13}$ and Thomas Doyle, ${ }^{4}$ for providing colleague reviews of the compiled draft report.

\footnotetext{
${ }^{1}$ Austin Peay State University.

${ }^{2}$ North Carolina State University.

${ }^{3}$ U.S. Forest Service.

${ }^{4}$ U.S. Geological Survey.

${ }^{5}$ U.S. Environmental Protection Agency.

${ }^{6}$ NatureServe.

${ }^{7}$ Virginia Polytechnic Institute and State University.

${ }^{8}$ Middle Tennessee State University.

${ }^{9}$ University of North Carolina.

${ }^{10}$ Landcare Research (New Zealand).

${ }^{11}$ Arkansas Natural Heritage Commission.

${ }^{12}$ West Virginia Division of Natural Resources.

${ }^{13}$ Tennessee Department of Environment and Conservation.
} 


\title{
Insular Ecosystems of the Southeastern United States: A Regional Synthesis to Support Biodiversity Conservation in a Changing Climate
}

\author{
By Jennifer M. Cartwright and William J. Wolfe
}

\begin{abstract}
In the southeastern United States, insular ecosystems - such as rock outcrops, depression wetlands, high-elevation balds, flood-scoured riparian corridors, and insular prairies and barrens-occupy a small fraction of land area but constitute an important source of regional and global biodiversity, including concentrations of rare and endemic plant taxa. Maintenance of this biodiversity depends upon regimes of abiotic stress and disturbance, incorporating factors such as soil surface temperature, widely fluctuating hydrologic conditions, fires, flood scouring, and episodic droughts that may be subject to alteration by climate change. Over several decades, numerous localized, site-level investigations have yielded important information about the floristics, physical environments, and ecological dynamics of these insular ecosystems; however, the literature from these investigations has generally remained fragmented. This report consists of literature syntheses for eight categories of insular ecosystems of the southeastern United States, concerning (1) physical geography, (2) ecological determinants of community structures including vegetation dynamics and regimes of abiotic stress and disturbance, (3) contributions to regional and global biodiversity, (4) historical and current anthropogenic threats and conservation approaches, and (5) key knowledge gaps relevant to conservation, particularly in terms of climate-change effects on biodiversity. This regional synthesis was undertaken to discern patterns across ecosystems, identify knowledge gaps, and lay the groundwork for future analyses of climate-change vulnerability. Findings from this synthesis indicate that, despite their importance to regional and global biodiversity, insular ecosystems of the southeastern United States have been subjected to a variety of direct and indirect human alterations. In many cases, important questions remain concerning key determinants of ecosystem function. In particular, few empirical investigations in these ecosystems have focused on possible climate-change effects, despite the well-documented ecological effects of climate change at a global level. Long-term management of these ecosystems could benefit from increased scientific effort to characterize and quantify the linkages between changing environmental conditions and the ecological processes that sustain biodiversity.
\end{abstract}





\section{Chapter A. Introduction}

The southeastern United States is rich in biodiversity (Noss, 2013) and contains multiple "hotspots" of rarityweighted richness (bold terms can be found in glossary) for globally rare taxa (Stein and others, 2000; NatureServe, 2013). In part, this is because of concentrations of rare and endemic plant taxa (Marcinko, 2007), which are clustered into several "centers of endemism" including the southern Appalachian Mountains, the Nashville (Central) Basin of Tennessee and Alabama, and the Mid-Atlantic Coastal Plain (see maps in Estill and Cruzan, 2001; Sorrie and Weakley, 2001).

Across the southeastern United States, rare-species biodiversity is commonly associated with clusters of "habitat islands" (Collins and others, 2001; Edwards and Weakley, 2001) that form regional "archipelagos" (Loehle, 2006).
Although these insular ecosystems are critically important to the natural heritage of the southeastern United States (Stein and others, 2000; Noss, 2013), they have also been vulnerable to damage and destruction from many types of human activities (Noss and others, 1995). In some cases, insular ecosystems have been the subjects of extensive botanical inventories and localized ecological investigations; however, regional and conceptual syntheses are less common. Effective conservation and management of these ecosystems - especially in the face of climate-change-will likely require improved understanding of the key drivers of ecosystem dynamics, their biotic and abiotic interactions, and their sensitivities to human alteration.

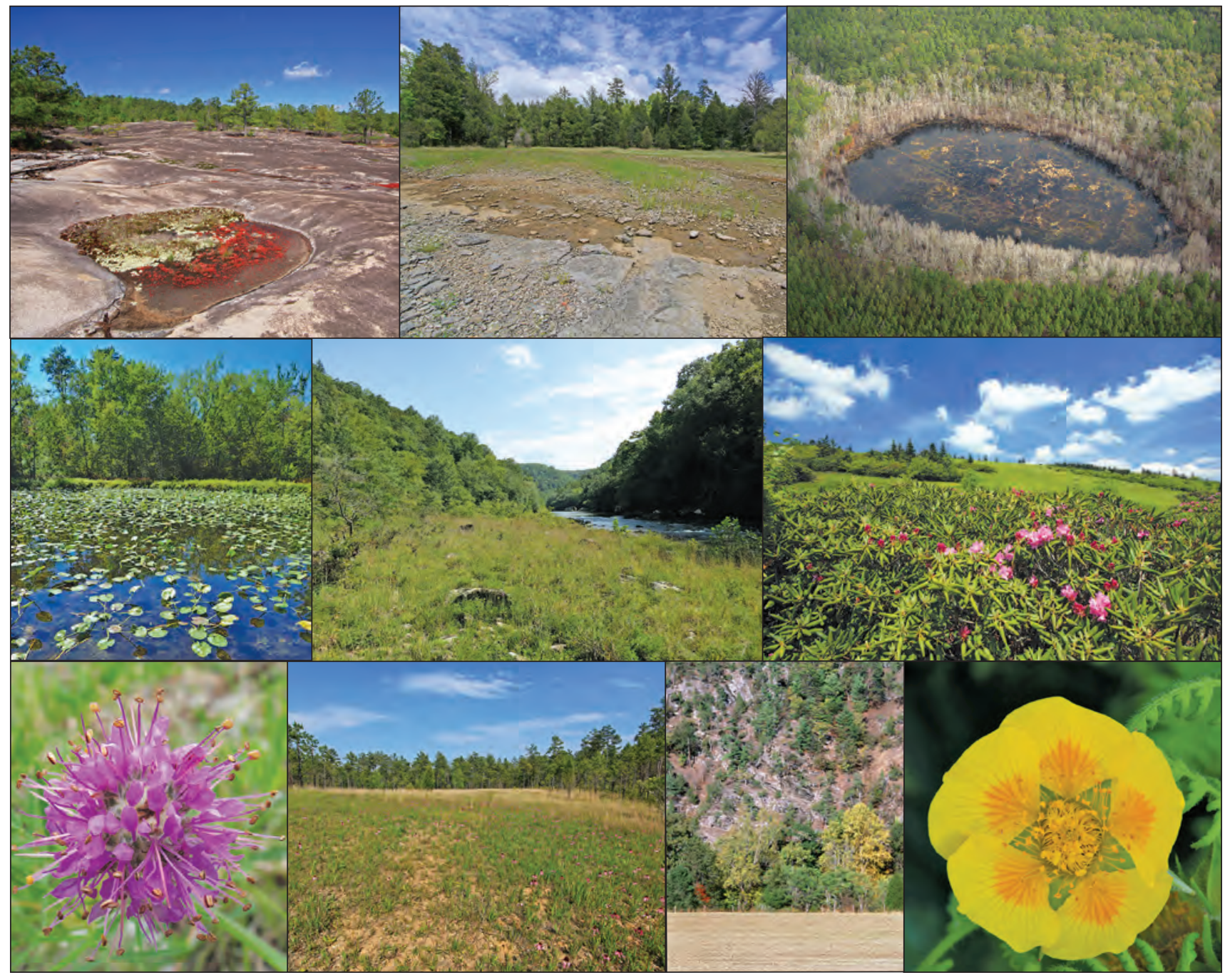




\section{Background}

Recognition of the ecological importance of islands dates back to the work of Darwin in the Galapagos Archipelago and that of Wallace in the Malay Archipelago (Simberloff, 1974). MacArthur and Wilson $(1963,1967)$ pioneered the study of island biogeography, and soon afterward the conceptual models and analytic approaches derived from studies of oceanic islands were adapted to metaphorical islands such as mountain tops (Brown, 1971; White and others, 1984) and lakes (Keddy, 1976; Browne, 1981). The ecological definition of "island" was expanded to include any "patch of suitable habitat surrounded by unfavorable environment that limits the dispersal of individuals" (Brown, 1978).

More recently, general patterns have been discerned linking biodiversity-rich insular ecosystems to localized aberrations in geologic, topographic, edaphic, or geomorphic conditions (Collins and others, 2001), termed "landscape anomalies" by Kelso and others (2001). Spatial heterogeneity in these conditions creates geodiversity (Gray, 2013), a landscape quality that may be important to conserving biodiversity as climatic conditions change (Anderson and Ferree, 2010; Beier and Brost, 2010; Schloss and others, 2011; Groves and others, 2012). Indeed, geodiversity conservation has been increasingly recognized for its importance in planning for climate-change mitigation of biodiversity losses (Anderson and others, 2015; Comer and others, 2015). Thus, scientifically based conservation of insular ecosystems may prove important not only to protecting current biodiversity but also to improving regional resiliency to climate change.

\section{Purpose and Scope}

This report presents a state-of-the-science review of the literature on selected ecosystems of the southeastern United States that meet five key criteria for ecological insularity:

1. Geographic discreteness, meaning spatial isolation from other occurrences of the same ecosystem type,

2. Distinctive geographic distributions reflecting highly specific geologic, edaphic, geomorphic, and (or) topographic controls,

3. Biogeographic endemism ${ }^{1}$ and (or) disjunction for vascular plant taxa,

4. Abiotic conditions and (or) disturbance regimes that produce stressful conditions for plant growth, and

\footnotetext{
'Anderson (1994) differentiated "habitat endemism" (confined to a particular habitat that may be geographically widespread) from "geographic endemism" (geographically limited to an area or region). The insular ecosystems reviewed here typically support plant taxa that are narrowly endemic based on habitat and display varying degrees of geographic endemism, depending on the species and geographic scale considered.
}

5. Sharply defined boundaries with steep environmental and ecological gradients to the surrounding landscape.

Rather than attempt an exhaustive review of all ecosystems meeting this definition within the southeastern United States ${ }^{2}$, this report focuses on eight categories of insular ecosystems for which sufficient scientific literature exists to enable a synthesis across site-level investigations:

1. Granite outcrops of the Piedmont region,

2. Limestone cedar glades,

3. Xeric limestone prairies,

4. Mid-Appalachian shale barrens,

5. High-elevation outcrops and balds of the southern Appalachians,

6. Carolina bays,

7. Karst-depression wetlands, and

8. Riverscour ecosystems.

The geographic focus of this selection was the area east of the Mississippi River and south of the Ohio and Potomac Rivers, although some insular ecosystems have occurrences beyond these boundaries. Peninsular Florida was excluded from this review because this region contains many insular ecosystems and arguably deserves its own regional synthesis.

\section{Approach}

The approach to assessing the state-of-the-science for the selected insular ecosystems took the form of literature syntheses addressing the physical geography, abiotic conditions, biodiversity contributions, plant community types, vegetation dynamics, and documented anthropogenic threats to each ecosystem. The body of this report is organized in eight chapters (B through I), each focused on one of the selected insular ecosystems. These eight chapters:

1. Summarize basic information concerning geographic distribution ${ }^{3}$, geologic and topographic context, and physical environmental characteristics,

\footnotetext{
${ }^{2}$ Additional ecosystems in the southeastern United States meeting this definition are listed in table $\mathrm{J}-1$.

${ }^{3} \mathrm{~A}$ map is presented for each insular ecosystem, showing the general geographic distribution of ecosystem occurrence or, where appropriate, selected sites where previous investigations have been performed. Exhaustive depiction of all ecosystem occurrences was outside the scope of this study and would likely be impracticable for most ecosystems due to incompleteness of regional surveys. Similarly, showing map locations of all place names mentioned in the text would have been prohibitively complex at the map scales used in this report; therefore, the maps included here are for general illustrative purposes only.
} 
2. Provide a synthesis of known ecological drivers and determinants of community structures, including factors regulating spatial distributions of taxa and successional dynamics,

3. Discuss prominent contributions to regional and global biodiversity, especially in terms of endemic plant taxa, disjunct plant populations, and provision of faunal habitat,

4. Describe historical and current threats to ecosystems as well as established conservation approaches to mitigate these threats, and

5. Identify key areas where further research is needed to help inform management and conservation of these ecosystems, particularly in terms of climate-change effects on biodiversity.

Particular focus was given to the distinctive regimes of abiotic stress factors (for example, thin soils, widely fluctuating hydrology, low soil $\mathrm{pH}$, or seasonally high soil surface temperatures) and disturbance events (for example, fires, droughts, and episodic scouring from high-energy floods) that characterize each ecosystem. Illustrative examples are included of how these abiotic stresses and disturbance regimes are reflected in specialized adaptations promoting stress tolerance in the plant taxa that are endemic to, or characteristic of, each ecosystem. Where applicable, the report discusses the mechanisms by which stress and disturbance regimes help shape successional dynamics and spatial vegetation patterns, for example by regulating rates of woody encroachment into herbaceous communities or by producing species turnover along abiotic gradients. For each ecosystem, existing conservation practices are described along with human activities and resulting processes that have been documented in the literature as prominent threats to ecosystem integrity.

Additionally, this report identifies key knowledge gaps concerning fundamental ecological questions for each ecosystem. Documentation of basic ecological characteristics is uneven across ecosystems in the published literature. Some of these systems, such as limestone cedar glades (Quarterman, 1950; Quarterman and others, 1993; Baskin and others, 2007), Appalachian shale barrens (Platt, 1951; Keener, 1983; Norris and Sullivan, 2002), and Carolina bays (Ross, 1987; Sharitz, 2003) have received attention for decades from botanists and geographers and are the subjects of relatively recent regional reviews. Others, such as karst-depression wetlands (Wolfe, 1996; Buhlmann and others, 1999) and riverscour ecosystems (Murdock and others, 2007; Wolfe and others, 2007) are known primarily from individual site-level studies across a number of discrete occurrences in several physiographic provinces, the findings of which have not previously been synthesized at a regional level. To expand the knowledge base from which to derive general patterns and pose new questions, this approach included reviews not only of easily accessible publications such as peer-reviewed journal articles but also of government reports, academic theses, and
Internet-inaccessible publications. In cases where inconsistencies in terminology and nomenclature have created confusion or ambiguity in the ecological literature, this report attempts to articulate these inconsistencies and clarify the definition of terms. In cases where disagreements have existed among researchers concerning important ecological questions, the conflicting viewpoints are presented, with particular emphasis on those supported by findings from rigorous empirical research. Scientific names of taxa are in accordance with those used by NatureServe (2015) unless otherwise noted. ${ }^{4}$ Names of ecological systems and plant associations generally follow the International Terrestrial Ecological Systems Classification (ITESC) and the U.S. National Vegetation Classification (USNVC), unless otherwise attributed (Jennings and others, 2009; Franklin and others, 2012). Conservation status rankings for associations and individual taxa are in accordance with NatureServe (2015) and are explained in the glossary.

This regional synthesis for insular ecosystems of the southeastern United States addresses one of the six U.S. Geological Survey, 2007 science strategy goals, "Understanding ecosystems and predicting ecosystem change" (U.S. Geological Survey, 2007). Particular attention was given to the ecological factors and forces that may prove sensitive to climate change. Effective management of these ecosystems in the face of increasing regional temperatures and changing precipitation patterns requires improved understanding in a number of areas, including the abiotic regulation of community structure, drivers of and constraints on succession, species-level physiological tolerance thresholds, and interspecific relationships. In general, these interactions and processes are inadequately understood for purposes of climate-change vulnerability assessment in the reviewed ecosystems. As such, an attempt was made to frame relevant questions for future research and, where warranted based on sufficient scientific documentation of climate-regulated ecosystem dynamics, to propose plausible and testable hypotheses concerning possible ecological effects of climate change. Because climate-change projections vary between different regionally downscaled climate models for the southeastern United States (Chen and others, 2003; Mearns and others, 2003; Mitchell and others, 2014), these hypotheses involved consideration of general and qualitative climatic changes rather than quantitative projections. Variability between models notwithstanding, climate change in the southeastern United States is likely to involve spatially and temporally variable temperature increases combined with changes in the timing, frequency, and magnitude of precipitation, possibly including increased storm intensity and increased drought severity (Karl and Knight, 1998; Chen and others, 2003; Mearns and others, 2003; Anchukaitis and others, 2006; Ibáñez and others, 2006; Mitchell and others, 2014). Thus, these types of changes were

\footnotetext{
${ }^{4}$ Recently renamed or reclassified taxa names may not appear in the updated form in NatureServe (2015). Naming revisions, reclassifications, synonyms, and basionyms are available in the International Plant Names Index (2015), the Integrated Taxonomic Information System (2015), and Natural Resources Conservation Service (2015).
} 
given primary consideration in this report for the formulation of climate-change hypotheses for insular ecosystems of the southeastern United States. Given the paucity of previous scientific investigations addressing climate-change effects in these ecosystems, the hypotheses presented here are necessarily speculative and should be viewed not as predictions but rather as starting points for future empirical work. Although answers are rare and questions are abundant concerning climate-change ecology in insular ecosystems, regional and conceptual syntheses constitute an important first step toward the formulation of scientifically grounded approaches to the conservation and management of these biodiverse ecosystems in the decades to come.

\section{References}

Anchukaitis, K.J., Evans, M.N., Kaplan, A., Vaganov, E., Hughes, M.K., Grissino-Mayer, H.D., and Cane, M., 2006, Forward modeling of regional scale tree-ring patterns in the southeastern United States and the recent influence of summer drought: Geophysical Research Letters, v. 33, no. 4, p. L04705.

Anderson, S., 1994, Area and endemism: The Quarterly Review of Biology, v. 69, no. 4, p. 451-471.

Anderson, M., Comer, P., Beier, P., Lawler, J., Schloss, C., Buttrick, S., Albano, C., and Faith, D., 2015, Case studies of conservation plans that incorporate geodiversity: Conservation Biology, v. 29, no. 3, p. 680-691.

Anderson, M., and Ferree, C., 2010, Conserving the stageClimate change and the geophysical underpinnings of species diversity: PLOS ONE, v. 5, no. 7, p. e11554.

Baskin, J., Baskin, C., and Quarterman, E., 2007, Flow diagrams for plant succession in the Middle Tennessee cedar glades: Journal of the Botanical Research Institute of Texas, v. 1, no. 2, p. 1131-1140.

Beier, P., and Brost, B., 2010, Use of land facets to plan for climate change-Conserving the arenas, not the actors: Conservation Biology, v. 24, no. 3, p. 701-710.

Brown, J., 1971, Mammals on mountaintops-Nonequilibrium insular biogeography: The American Naturalist, v. 105, no. 945 , p. $467-478$.

Brown, J., 1978, The theory of insular biogeography and the distribution of boreal birds and mammals: Great Basin Naturalist Memoirs, p. 209-227.

Browne, R., 1981, Lakes as islands-Biogeographic distribution, turnover rates, and species composition in the lakes of central New York: Journal of Biogeography, v. 8, no. 1, p. $75-83$.
Buhlmann, K., Mitchell, J., and Smith, L., 1999, Descriptive ecology of the Shenandoah Valley sinkhole pond system in Virginia: Banisteria, v. 13, p. 23-51.

Chen, M., Pollard, D., and Barron, E., 2003, Comparison of future climate change over North America simulated by two regional models: Journal of Geophysical Research, v. 108, no. D12, p. ACL 3-1-ACL 3-19.

Collins, B., White, P., and Imm, D., 2001, Introduction to ecology and management of rare plants of the southeast: Natural Areas Journal, v. 21, no. 1, p. 4-11.

Comer, P., Pressey, R., Hunter, M., Schloss, C., Buttrick, S., Heller, N., Tirpak, J., Faith, D., Cross, M., and Shaffer, M., 2015, Incorporating geodiversity into conservation decisions: Conservation Biology, v. 29, no. 3, p. 692-701.

Edwards, A., and Weakley, A., 2001, Population biology and management of rare plants in depression wetlands of the southeastern Coastal Plain, USA: Natural Areas Journal, v. 21 , no. 1 , p. $12-35$.

Estill, J., and Cruzan, M., 2001, Phytogeography of rare plant species endemic to the southeastern United States: Castanea, v. 66, no. 1, p. 3-23.

Franklin, S., Faber-Langendoen, D., Jennings, M., Keeler-Wolf, T., Loucks, O., Peet, R., Roberts, D., and McKerrow, A., 2012, Building the United States National Vegetation Classification: Annali di Botanica, v. 2, p. 1-9.

Gray, M., 2013, Geodiversity-Valuing and conserving abiotic nature: Chichester, Wiley-Blackwell.

Groves, C., Game, E., Anderson, M., Cross, M., Enquist, C., Ferdaña, Z., Girvetz, E., Gondor, A., Hall, K., Higgins, J., Marshall, R., Popper, K., Schill, S., and Shafer, S., 2012, Incorporating climate change into systematic conservation planning: Biodiversity and Conservation, v. 21, no. 7 , p. 1651-1671.

Ibáñez, I., Clark, J., Dietze, M., Feeley, K., Hersh, M., LaDeau, S., McBride, A., Welch, N., and Wolosin, M., 2006, Predicting biodiversity change - Outside the climate envelope, beyond the species-area curve: Ecology, v. 87, no. 8, p. 1896-1906.

International Plant Names Index, 2015, The international plant names index, accessed October 5, 2015, at http://www.ipni.org.

Integrated Taxonomic Information System, 2015, The Integrated Taxonomic Information System, accessed October 5, 2015, at http://www.itis.gov.

Jennings, M., Faber-Langendoen, D., Loucks, O., Peet, R., and Roberts, D., 2009, Standards for associations and alliances of the U.S. National Vegetation Classification: Ecological Monographs, v. 79, no. 2, p. 173-199. 
Karl, T.R., and Knight, R.W., 1998, Secular trends of precipitation amount, frequency, and intensity in the United States: Bulletin of the American Meteorological Society, v. 79, no. 2, p. 231-241.

Keddy, P., 1976, Lakes as islands-The distributional ecology of two aquatic plants, Lemna minor L. and L. trisulca L.: Ecology, v. 57, no. 2, p. 353-359.

Keener, C., 1983, Distribution and biohistory of the endemic flora of the mid-Appalachian shale barrens: The Botanical Review, v. 49, no. 1, p. 65-115.

Kelso, S., Hall, C., and Maentz, G., 2001, The role of landscape anomalies in regional plant conservation, in Southwestern Rare and Endangered Plants: Proceedings of the Third Conference: Flagstaff, Ariz., p. 13-19.

Loehle, C., 2006, Endemic plant distributions in Eastern North America-Implications for conservation: Journal of Forestry, v. 104, no. 8, p. 415-418.

MacArthur, R., and Wilson, E., 1963, An equilibrium theory of insular zoogeography: Evolution, v. 17, no. 4, p. 373-387.

MacArthur, R., and Wilson, E., 1967, The theory of island biogeography: Princeton, N.J., Princeton University Press.

Marcinko, S., 2007, Pattern and process in rare plant conservation-An assessment of the southeastern U.S.: Chapel Hill, N.C., University of North Carolina, Masters Thesis.

Mearns, L.O., Giorgi, F., Mcdaniel, L., and Shields, C., 2003, Climate scenarios for the southeastern U.S. based on GCM and regional model simulations: Climate, v. 60, p. 7-35.

Mitchell, R.J., Liu, Y., O’Brien, J.J., Elliott, K.J., Starr, G., Miniat, C.F., and Hiers, J.K., 2014, Future climate and fire interactions in the southeastern region of the United States: Forest Ecology and Management, v. 327, p. 316-326.

Murdock, N., Hughes, J., and Emmott, R., 2007, Understanding hydrologic links between "river prairies" and other threatened riparian resources of the Cumberland Plateau, in Selleck, J. ed., Natural resource year in review-2006, publication D-1859: Denver, Colo., National Park Service, Natural Resource Program Center, p. 45-46.

Natural Resources Conservation Service, 2015, The USDA plants database: Greensboro, N.C., U.S. Department of Agriculture, Natural Resources Conservation Service, National Plant Data Team, accessed September 25, 2015, at http://plants.usda.gov.

NatureServe, 2013, NatureServe rarity-weighted richness model of critically imperiled and imperiled species in the United States (updated in 2013), accessed November 15, 2015, at http://www.natureserve.org/ conservation-tools/natureserve-hotspots-map.
NatureServe, 2015, NatureServe Explorer-An online encyclopedia of life [web application], ver. 7.1, accessed October 7, 2015, at http://www.natureserve.org/explorer.

Norris, S., and Sullivan, R., 2002, Conservation assessment for the mid-Appalachian shale barrens: Elkins, W.Va., West Virginia Division of Natural Resources.

Noss, R., 2013, Forgotten grasslands of the south: Washington, D.C., Island Press.

Noss, R., LaRoe, E., and Scott, J., 1995, Endangered ecosystems of the United States - A preliminary assessment of loss and degradation: Washington, D.C., U.S. Department of the Interior.

Platt, R., 1951, An ecological study of the mid-Appalachian shale barrens and of the plants endemic to them: Ecological Monographs, v. 21, no. 4, p. 269-300.

Quarterman, E., 1950, Major plant communities of Tennessee cedar glades: Ecology, v. 31, no. 2, p. 234-254.

Quarterman, E., Burbanck, M., and Shure, D., 1993, Rock outcrop communities - Limestone, sandstone, and granite, in Martin, W., Boyce, S., and Echternacht, A. eds., Biodiversity of the southeastern United States-Upland terrestrial communities: New York, John Wiley and Sons, Inc., p. 35-86.

Ross, T., 1987, A comprehensive bibliography of the Carolina bays literature: The Journal of the Elisha Mitchell Scientific Society, v. 103, no. 1, p. 28-42.

Schloss, C., Lawler, J., Larson, E., Papendick, H., Case, M., Evans, D., DeLap, J., Langdon, J., Hall, S., and McRae, B., 2011, Systematic conservation planning in the face of climate change-Bet-hedging on the Columbia Plateau: PLOS ONE, v. 6, no. 12, p. e28788.

Sharitz, R., 2003, Carolina bay wetlands-Unique habitats of the southeastern United States: Wetlands, v. 23, no. 3, p. 550-562.

Simberloff, D., 1974, Equilibrium theory of island biogeography: Annual Review of Ecology and Systematics, v. 5, p. 161-182.

Sorrie, B., and Weakley, A., 2001, Coastal Plain vascular plant endemics-Phytogeographic patterns: Castanea, v. 66, no. 1, p. $50-82$.

Stein, B., Kutner, L., and Adams, J., eds., 2000, Precious heritage - The status of biodiversity in the United States: New York, N.Y., Oxford University Press.

U.S. Geological Survey, 2007, Facing tomorrow's challengesU.S. Geological Survey Science in the decade 2007-2017: U.S. Geological Survey Circular 1309, 67 p. 
White, P., Miller, R., and Ramseur, G., 1984, The speciesarea relationship of the southern Appalachian high peaks - Vascular plant richness and rare plant distributions: Castanea, v. 49, no. 2, p. 47-61.

Wolfe, W.J., 1996, Hydrology and tree-distribution patterns of karst wetlands at Arnold Engineering Development Center, Tennessee: U.S. Geological Survey Water-Resouces Investigations Report 96-4277, 46 p.

Wolfe, W.J., Fitch, K.C., and Ladd, D.E., 2007, Alluvial bars of the Obed Wild and Scenic River, Tennessee: U.S. Geological Survey Scientific Investigations Map 2007-2972, 1 sheet. 


\section{Chapter B. Granite Outcrops of the Piedmont}

\section{Introduction}

Within the Piedmont Physiographic Province (Fenneman, 1938), differential weathering has produced outcroppings of relatively resistant granite schists and gneisses surrounded by deeper soils from more easily weathered parent material (Shure, 1999). Piedmont granite outcrops are thus "terrestrial islands of rock" surrounded by forest (Caspary and Affolter, 2012) that contain a diverse array of microhabitats and associated plant communities subject to a range of hydrologic conditions, from generally xeric to seasonally variable to semipermanently inundated (Quarterman and others, 1993). These outcrops are particularly noteworthy for their high numbers of rare and endemic vascular plant species (Shure, 1999; Loehle, 2006; Marcinko, 2007) and for the presence of soil patches within topographic depressions of the rock surface that function as "islands within islands" (fig. B-1).

\section{Geographic Range}

Granite outcrops are widely distributed throughout the Piedmont Physiographic Province, from eastern Alabama to southern Virginia (fig. B-2). The Piedmont Physiographic Province slopes from the Blue Ridge Mountains in the east toward the Fall Line, which is the boundary with the Atlantic Coastal Plain. Granite outcrops are concentrated in the zone of the Piedmont nearest the Fall Line, a zone approximately 120 miles (about 195 kilometers) wide that extends about 700 miles (about 1,130 kilometers) from Alabama to Virginia (Oosting and Anderson, 1939; McVaugh, 1943). Within this zone, granite outcrops range in size from less than 100 square feet to hundreds of acres (a few square meters to hundreds of hectares) (McVaugh, 1943; Tate, 2005). The total area of Piedmont granite outcrops is estimated at close to 8,000 acres (about 3,200 hectares), with 6,000 acres (about 2,500 hectares)

Figure B-1. Camp Meeting Rock Preserve, Heard County, Georgia.

Photograph by Alan M. Cressler, U.S. Geological Survey. 


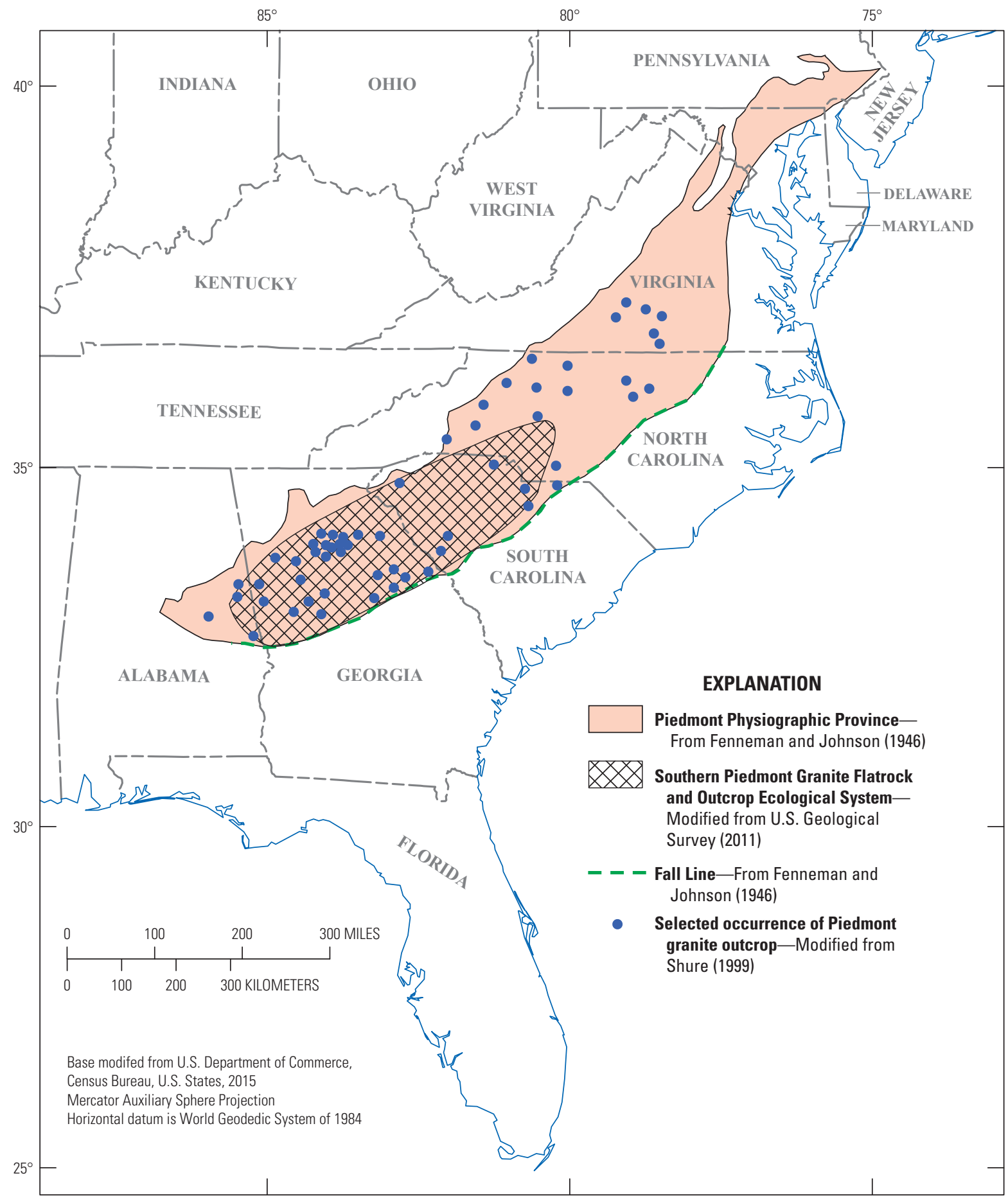

Figure B-2. Geographic distribution of Piedmont granite outcrops.

in Georgia where the largest outcrops are present (McVaugh, 1943; Tate, 2005). Although more attention has been paid to granite outcrops along the Fall Line, Wyatt and Fowler (1977) pointed out that, at least in North Carolina, two other bands of granite outcrops run roughly parallel to the Fall Line zone of outcrops but considerably to the west: one along the center of the Piedmont, the other just east of the Blue Ridge Mountains. These three bands of outcrops generally correspond to the three main granite belts within the Piedmont, all oriented in a northeast-to-southwest direction. The western outcrops tend to be more steeply sloping and have more fissures and crevices than the outcrops along the Fall Line (Wyatt and Fowler, 1977). Granite outcrops also are present in a number of other regions of North America, including the Wichita Mountains of Oklahoma, the Sierra Nevada of California, and the Central Mineral Region of Texas, with the Texas outcrops showing similarities in life-form spectra to those in the Piedmont but with substantially lower rates of endemism (Walters and Wyatt, 1982). 


\section{Physical Geography}

At least two distinct types of granite outcrops are present in the Piedmont: relatively flat outcrops at the same general elevation as the surrounding landscape and domed monadnocks (Stone Mountain in DeKalb County, Georgia, being the most well-known example) which rise as high as 700 feet (about 215 meters) above the surrounding rolling terrain (Keever and others, 1951; Burbanck and Platt, 1964; Shure, 1999; Belden and others, 2003). The exposed rock may be true granite or may contain porphyritic granite, gneiss, or granodiorite, and is generally high in silica and aluminum and low in iron and magnesium (McVaugh, 1943; Belden and others, 2003; Tate, 2005). In comparison to other rock outcrop types, granite outcrops are relatively smooth with few cracks, crevices, or fractures, and they lack the surface layer of rock fragments that is typical of limestone cedar glades (Oosting and Anderson, 1937; McVaugh, 1943). A characteristic feature of flat and domed granite outcrops is the presence of shallow depressions (sometimes called "solution pits," fig. B-3) that may be seasonally ponded if the rock rim is continuous but otherwise are xeric (Oosting and Anderson, 1939; Burbanck and Platt, 1964; Shure, 1999). The formation of solution pits is primarily driven by physical weathering - including scouring by wind and water - and by the accumulation of organic and inorganic deposits rather than by biochemical weathering from lichens or mosses (McVaugh, 1943; Burbanck and Platt, 1964).

\section{Stress and Disturbance Regimes}

The primary components of the stress regime in granite outcrops stem from the paucity - and in many places the absence - of soil. Even within granite outcrop depressions in the more advanced stages of succession, soil thickness is markedly less than in the surrounding woodland and forest. Canopy cover is virtually nonexistent because so few trees reach maturity (Keever and others, 1951). As a result, the stress regime of many microhabitats within granite outcrops is characterized by high solar irradiance, widely fluctuating temperatures with maximums as high as 55 degrees Celsius $\left({ }^{\circ} \mathrm{C}\right)$, limited water availability due to rapid evaporation and limited water storage by thin soil: a combination of factors producing a "microenvironmental desert" environment within a region with ample precipitation (Phillips, 1982; Shure, 1999; Austin and others, 2009). Wet depressions experience additional abiotic stress conditions due to fluctuation between hydrologic extremes because the depressions become inundated by rain events but also become desiccated during dry periods (Oosting and Anderson, 1937; Keever and others, 1951).

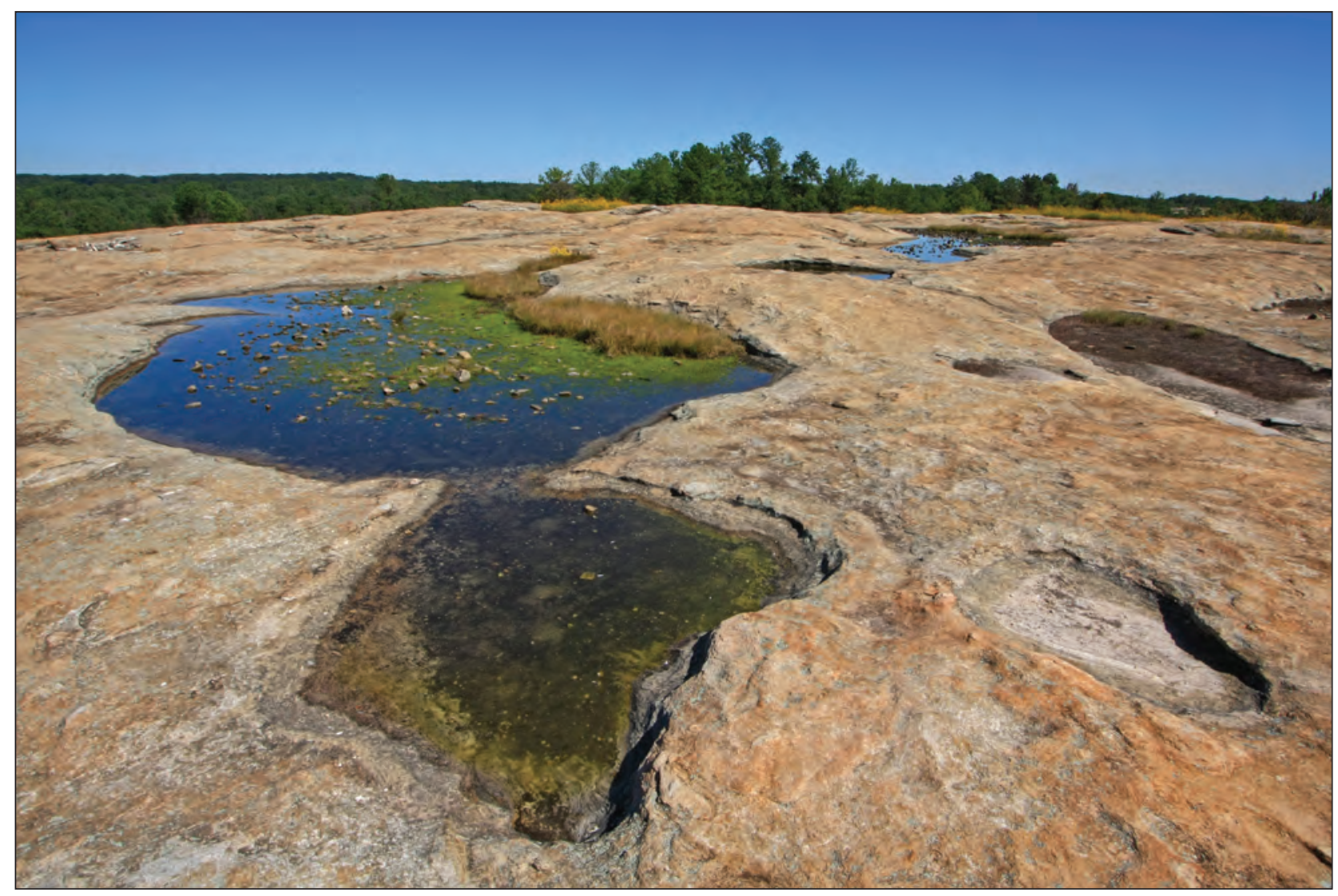

Figure B-3. Solution pits in a granite outcrop, Davidson-Arabia Mountain Nature Preserve, Dekalb County, Georgia. Photograph by Alan M. Cressler, U.S. Geological Survey. 
Disturbance from fire may play some role in ecosystem maintenance and the inhibition of succession. Oosting and Anderson (1939) observed that "every outcrop has evidence of a fairly recent fire," an idea supported by McVaugh (1943), Keever and others (1951), and Wyatt and Fowler (1977). However, the low biomass levels and patchy distribution of vegetation in granite outcrops might be expected to limit the spread and intensity of fire. The relative importance of fire as a disturbance factor maintaining ecosystem integrity, including its possible role in suppressing invasion by weedy species within outcrop ecotones, is not fully understood (Caspary and Affolter, 2012).

On the sloping outcrops of the eastern Piedmont, vegetation is susceptible to several types of disturbance. For example, disturbance events can result when runoff from heavy rains releases and washes away vegetation mats that had formed over hundreds or thousands of years (Oosting and Anderson, 1937; McVaugh, 1943; Wyatt and Fowler, 1977; Tate, 2005). On Rocky Face Mountain (Alexander County, North Carolina), Keever and others (1951) speculated that vegetation mats might have been dislodged and removed when logging operations in the early 1900s rolled logs down the mountain across areas of granite outcrop. Another form of disturbance is exfoliation, an erosion process in which shells of granite ranging in thickness from less than an inch to more than ten feet (a few centimeters to several meters) are loosened from the bedrock by freeze-thaw cycles and gradual weathering (Burbanck and Platt, 1964). Highly localized disturbance events can also result when a dead or windblown tree is uprooted because this uprooting typically destroys the vegetation mats in which the tree was growing. McVaugh (1943) and Keever and others (1951) noted that moisture conditions typically limit the size and age of trees, which are prone to being uprooted due to insufficient anchorage in shallow soils. Wyatt and Fowler (1977), Phillips (1981), and Burbanck and Phillips (1983) suggested that succession on granite outcrops is thus fundamentally limited by moisture and nutrient availability and that disturbance effects from drought, erosion, and wind generally preclude the achievement of a climax or steady-state seral stage such as that of the surrounding forest.

\section{Community Types and Vegetation Dynamics}

Granite outcrops harbor several distinct microhabitats, each with its own characteristic species assemblages and patterns of succession. These microhabitats include exposed rock surfaces, rock crevices, dry depressions, periodically ponded depressions, persistent pools, soil islands (accumulations of deeper soil that are sometimes called vegetation islands or vegetation mats), seepage areas, and ecotones to the surrounding forest (Oosting and Anderson, 1937; McVaugh, 1943; Wyatt and Fowler, 1977; Shure, 1999).

\section{Exposed Rock Surfaces}

Much of the area of granite outcrops is exposed bedrock with virtually no soil development. The first pioneers of bare granite surfaces are invariably lichens and mosses (fig. B-4) such as Staurothele diffractella, Peccania kansana, Grimmia laevigata, and Rhacomitrium heterostichum) (Oosting and Anderson, 1937; McVaugh, 1943; Keever and others, 1951; Wyatt and Stoneburner, 1982). Ability to colonize this harsh environment requires tolerance of xeric conditions, temperature fluctuations, and high levels of light intensity (Keever, 1957). Pioneer establishment facilitates the initial stages of soil development by way of several interrelated processes. Mosses and lichens trap and accumulate mineral particles that are blown across rock surfaces by wind or washed across by storm runoff and contribute organic matter (Oosting and Anderson, 1937; Keever and others, 1951). Through their associations with bacteria, lichens and bryophytes also play roles in soil nitrogen fixation (Snyder and Wullstein, 1973). Spatial distribution of species in these early successional communities is likely governed by complex competitive dynamics. Grimmia mats typically continue their pioneer expansion at their periphery and are simultaneously invaded in their centers (the oldest, deepest part of the mats) by lichens (Cladonia leporina), other mosses (Selaginella rupestris, Polytrichum ohioense), and sometimes vascular plants. The presence of lichens often retards the growth of Grimmia (Keever, 1957; Shure, 1999). Keever and others (1951) noted that the surfaces of these mats are extremely compact and speculated that this surface inhibits seedling establishment, resulting in relatively slow succession on moss/lichen mats that form on level, bare rock. For example, the granite outcrop communities studied by Leslie and Burbanck (1979) were dominated by mats of Polytrichum and Selaginella with relatively few other species present, indicating limited or slow succession. However, Oosting and Anderson (1939) maintained that, given sufficient time, these mats will develop soil layers sufficient to support drought-resistant woody shrub species, although these shrubs tend to be stunted and slow growing. Shure (1999) suggested that different rates of mat formation and successional development may be geographically determined, with slower rates in Georgia where lichens are the primary invaders and faster rates in North Carolina and Virginia where mats are more successfully invaded by vascular plants.

\section{Rock Crevices}

Crevices range in size from hairline cracks sustaining only one or two individual herbaceous plants to large fissures supporting woody shrubs and small trees. Explorers of granite outcrops in the eastern Piedmont (along the Fall Line) have noted the scarcity of crevices and fissures and generally have excluded them from their discussions of community types or succession pathways (Oosting and Anderson, 1939; Keever 


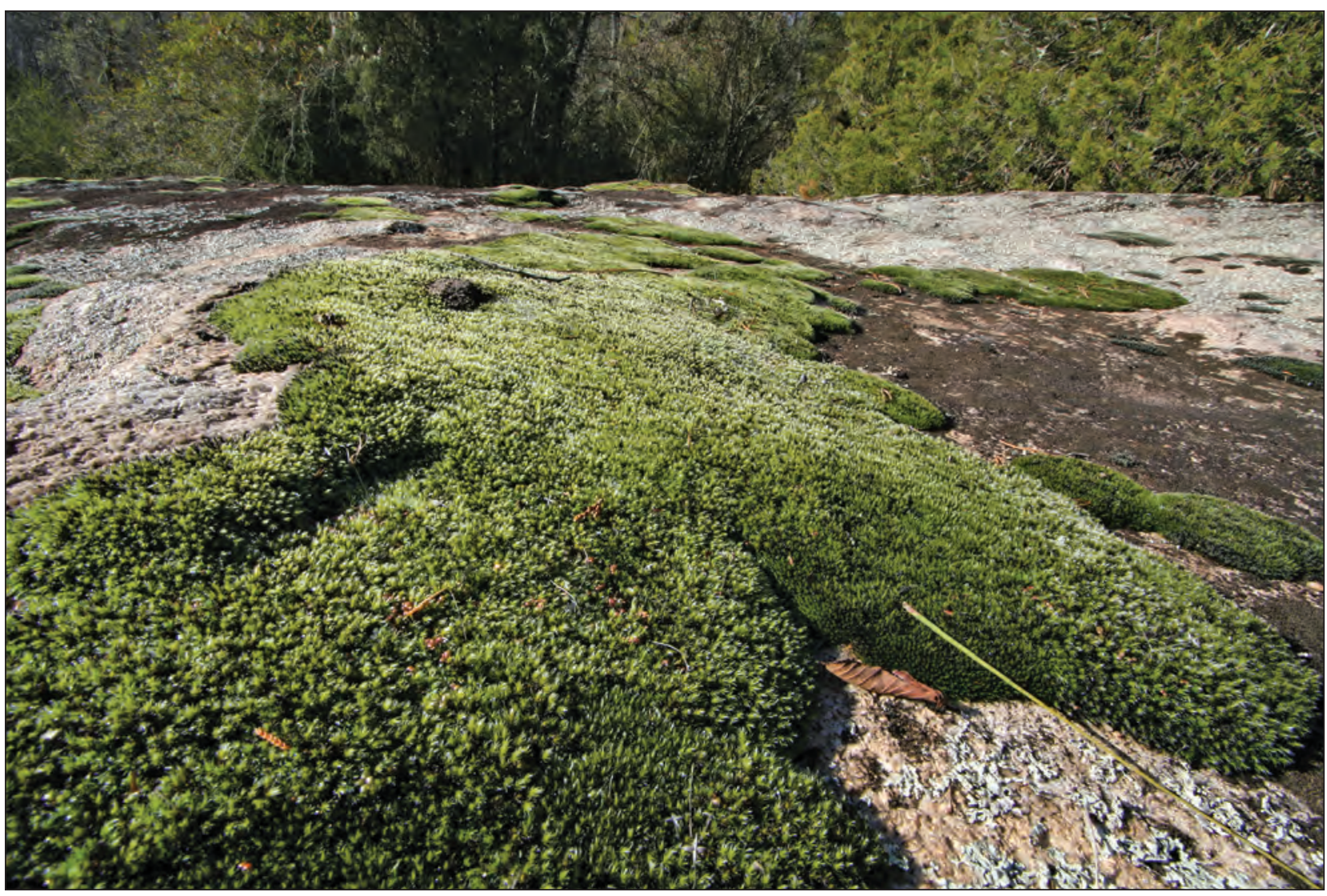

Figure B-4. Moss-colonized rock surface, Davidson-Arabia Mountain Nature Preserve, Dekalb County, Georgia. Photograph by Alan M. Cressler, U.S. Geological Survey.

and others, 1951; Shure, 1999). Wyatt and Fowler (1977) observed that crevice formation is more common on more steeply sloped granite outcrops of the western Piedmont near the Blue Ridge Mountains, but did not extensively describe crevices as a community or successional type.

\section{Dry Depressions}

For depressions in which the downslope rock rim has been broken or partially eroded, such that rainfall is not retained and moisture evaporates quickly, hydrologic conditions are seasonally to semipermanently xeric. These depressions do accumulate and retain soil and minerals washed across them; however, this soil is typically extremely thin, dry, and hard. Oosting and Anderson (1937) suggested that these dry depressions "are perhaps less favorable habitats than the bare rock itself" because the soil layer is insufficient for most plants but its presence excludes the bare rock pioneers. In summer, dry depressions may appear completely unvegetated but in spring can support populations of Phemeranthus species, Portulaca smallii, Agrostis elliottiana, and - given sufficiently deep soilDiamorpha smallii (Oosting and Anderson, 1937).

\section{Periodically Ponded Depressions}

Where the rock rim of a depression is continuousallowing rainfall to be retained - and where the depression is shallow enough that water completely evaporates during dry periods, hydrologic conditions span both extremes, from xeric to inundated (Oosting and Anderson 1937; Keever and others, 1951). The few pioneer species that can survive these widely fluctuating hydrologic conditions include members of Grimmia, Cladonia, and Polytrichum genera. Once these species become established, they moderate the hydrologic regime and build soil within the depression. This process facilitates succession similar to that on bare rock, but with typically thicker soil and more moisture availability allowing for a more diverse assemblage of species (Oosting and Anderson, 1939). The semiaquatic endemics Isoetes melanospora, Isoetes tegetiformans, and Amphianthus pusillus apparently can survive some degree of desiccation and so may be able to colonize some periodically ponded depressions depending on the duration of dryness (Shure, 1999). 


\section{Persistent Pools}

Generally located atop granitic domes as opposed to flat outcrops, persistent pools are the least common of the depression types because few depressions are sufficiently large or deep to be persistently inundated (Oosting and Anderson, 1939; Burbanck and Platt, 1964; Shure, 1999). These pools support the Piedmont Granite Flatrock Glade Seasonal Pool association, which is ranked G1. Persistent pools have been documented primarily in Georgia and are conspicuously absent in North Carolina (Wyatt and Fowler, 1977) and Virginia (Shure, 1999). These pools are the primary habitat for the three semiaquatic endemics of granite outcrops: I. melanospora, I. tegetiformans, and A. pusillus. Around the pools' circumferences at the water's edge are communities often dominated by Polytrichum ohioense that resemble those found in periodically ponded depressions (Oosting and Anderson, 1939). These communities around the water's edge, along with Eleocharis obtusa and Typha latifolia, which form clumps in the inundated zone, contribute to soil formation such that persistent pools follow succession pathways to become moist or marshy depressions (Oosting and Anderson, 1939).

\section{Soil Islands}

In certain depressions, substantial accumulation of soil has occurred (fig. B-5). In many cases, the surrounding exposed rock is sloped and the lower rim of the depression has partially eroded away, allowing rainfall to enter and exit (Burbanck and Platt, 1964). This topography, combined with the water-retaining capacity of accumulated soil, helps moderate the hydrology of soil islands such that they tend not to experience the xeric or saturated conditions characteristic of periodically ponded depressions. As succession proceeds, soil organic matter, plant biomass, and vertical stratification increase (Shure and Ragsdale, 1977).

Burbanck and Platt (1964) and Shure (1999) assigned soil island communities to one of four general types in order of increasing soil thickness and island area: Diamorpha, lichen-annual herb, annual-perennial herb, and herb-shrubtree. Burbanck and Phillips (1983) resampled soil islands in Georgia over 9- and 20-year intervals to confirm that these four community types do indeed represent seral stages, with increased soil depth corresponding to floristic changes for about half of the soil islands studied. Phillips (1981)

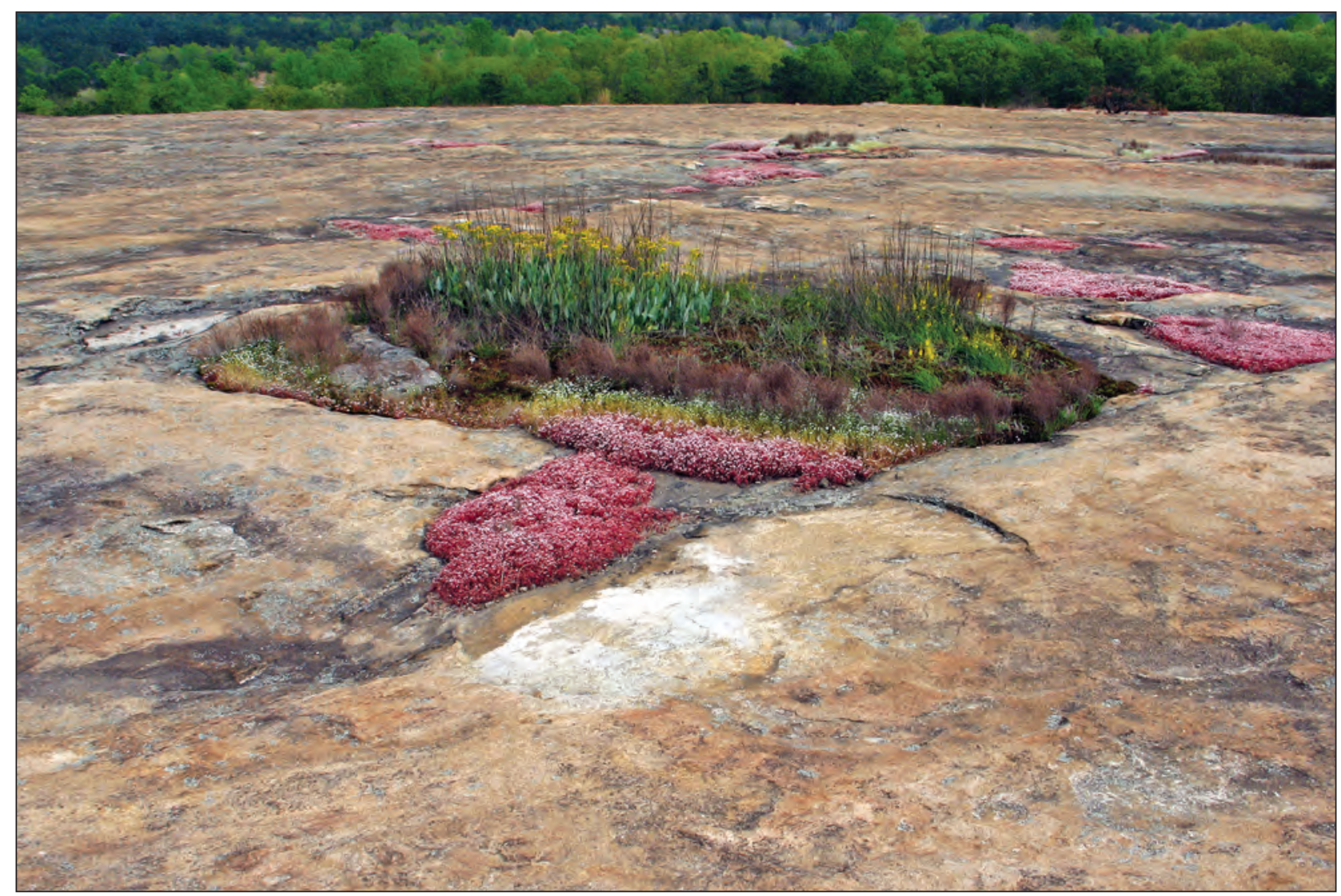

Figure B-5. Soil island, Davidson-Arabia Mountain Nature Preserve, Dekalb County, Georgia. Photograph by Alan M. Cressler, U.S. Geological Survey. 
demonstrated that, although community composition tends to progress through the seral stages in the order described here, tree mortality from droughts may cause reversion from the herb-shrub-tree seral stage to the herb-shrub stage.

Houle (1990) demonstrated at Arabia Mountain-a domed monadnock east of Atlanta, Georgia - that plantspecies richness was positively associated with island area (in support of the species-area hypothesis of island biogeography) and even more strongly with soil depth (in support of the habitat-diversity hypothesis if the soil depth gradient is considered a series of distinct habitats). The findings of Houle (1990) and Houle and Phillips (1988) also indicate that plant diversity and patterns of seed abundance, respectively, change with advancing seral stages, which are in turn associated with declining abiotic stress (deeper soil, increased water retention and nutrient availability, and reduction in temperature fluctuation). Shure and Ragsdale (1977) demonstrated a peak in plant diversity at intermediate seral stages and stressed the importance of interspecific competition for nutrients and moisture as a regulator of plant community composition as succession proceeds. Houle and Phillips (1988, 1989) also demonstrated that interspecific interactions play important roles in determining community structure of soil islands. Specifically, in communities at the lichen-annual seral stage, community structure is influenced by the presence of shallow-soil species (which facilitate the establishment of deeper-soil species) and by the presence of Diamorpha smallii (which helps maintain lichen and moss cover).

Although studied less extensively than plant community dynamics, animal community composition has also been shown to change over the course of succession in soil islands. Austin and others (2009) demonstrated that island soils at different seral stages harbor different community structures of soil nematodes. Shure and Ragsdale (1977) found that macroarthropod densities, biomass, and diversity increased as succession proceeded and that microarthropod diversity also increased with decreasing seasonal variability in soil physical conditions.

\section{Marginal Zones and Seepage Areas}

Ecotones from bare rock to soil islands or to the surrounding forest contain marginal zones and associated areas of seepage. Such marginal zones support associations such as the Pine/Granitic Flatrock Border Woodland, a G3-ranked association. Soil inputs and losses are believed to be fairly balanced in these ecotones, a factor promoting relative stability in community structure (Oosting and Anderson, 1939; Shure, 1999). These ecotones are vulnerable to invasions of exotic species, however, such that natural disturbance from fire (or, in its absence, controlled burn programs) are important regulators of community composition (Caspary and Affolter, 2012). On outcrops with gradual slopes, precipitation that percolates down through the vegetation and soil of isolated vegetation mats, soil islands, or the surrounding woodland and forest is intercepted by the granite bedrock and diverted laterally. Thus, in transitional zones to exposed bedrock downslope of these vegetated areas, seepage is an important contributor to water availability. In some cases, seepage is sufficient to support characteristic bog species, including Sphagnum species, Bryum pseudotriquetrum, and Philonotis fontana (Oosting and Anderson, 1939; Shure, 1999). Marginal zones adjacent to forest are often partially shaded, adding to their ability to retain moisture, and protected from the scouring action of heavy rain such that a layer of organic debris accumulates (Oosting and Anderson, 1939). A number of herbaceous and "weedy" species (not endemic to the outcrops) are capable of colonizing this habitat.

\section{Contributions to Regional Biodiversity}

Like other rock outcrops in the southeastern United States, Piedmont granite outcrops make important contributions to regional biodiversity (Quarterman and others, 1993). In particular, Piedmont granite outcrops provide habitat to plant and animal taxa of conservation concern, including endemic and biogeographically disjunct taxa (Shure, 1999; Marcinko, 2007).

\section{Endemic and Biogeographically Disjunct Taxa}

Piedmont granite outcrops support a number of plant taxa of conservation concern (table 3-1 in appendix 3). Although many of these taxa are endemic (or nearly so) to Piedmont granite outcrops, the enumeration and identification of endemics has involved several types of ambiguity. Over decades, a number of lists have been compiled representing species referred to as "endemic" or else as characteristic of Piedmont granite outcrops (McVaugh, 1943; Burbanck and Platt, 1964; Shure, 1999). These lists were based on study areas ranging from hundreds of outcrops across several States to single visits to a relatively small number of outcrops. Although some overlap exists between lists, application of the terms "endemic" and "near endemic" are highly variable among investigators. For example, McVaugh (1943) included in his list of "supposedly endemic" taxa Liatris microcephala, which also is found on the Cumberland Plateau in sandstone outcrop ecosystems (Schmalzer and others, 1985) and on flood-scoured cobble bars along rivers (Bailey and Coe, 2001). Indeed, a number of taxa are generally restricted to rock outcrop ecosystems but also are found on sandstone or other substrates and have distributions that include other physiographic provinces. These taxa include Diamorpha smallii, Minuartia uniflora, Talinum teretifolium, and Cuscuta harperi (Baskin and Baskin, 1988; Reinhard and Ware, 1989; Spaulding, 2013). Some taxa common to granite outcrops (including Diodia teres, T. teretifolium, Commelina erecta, Oenothera fruticosa, Opuntia humifusa var. humifusa, and Croton willdenowii) have also been documented on diabase 
cedar glades of the Piedmont, which are habitats with considerably higher $\mathrm{pH}$ (LeGrand, 1988). Additionally, disagreements and ambiguity regarding taxonomic classification have complicated the enumeration of endemics, as has been the case with Isoetes taxa (Matthews and Murdy, 1969; Boom, 1982).

These uncertainties notwithstanding, the narrow endemism of several taxa is widely accepted. These taxa include the semiaquatic Amphianthus pusillus and Isoetes species associated with persistent pools and species occupying various niches along gradients between bare rock and surrounding ecosystems, such as Sedum pusillum, Portulaca smallii, and Phacelia maculata (Shure, 1999). Three of these taxa are shown in figure B-6. Some endemic taxa belong to geographically widespread genera containing many other species (such as Juncus georgianus and Quercus georgiana), whereas others belong to monotypic genera (such as Amphianthus pusillus) (Braun, 1955; Hilton and Boyd, 1996). Certain genera, such as Isoetes, have several endemic sub-taxa with different degrees of geographic restriction and varying habitat characteristics (Matthews and Murdy, 1969).

The biogeography of granite outcrop endemics has been studied in some detail. The central Piedmont of Georgia has been referred to as the "center of endemism" for granite outcrop species because it has the greatest concentration of these endemics within the Piedmont region, geographically coinciding with the greatest concentration of exposed rock surfaces (Quarterman and others, 1993; Shure, 1999; Tate, 2005). Wyatt and Fowler (1977) noted characteristic geographic differences in community composition between western and eastern granite outcrops in North Carolina, highlighted by the phenomenon of competitive replacement whereby a species adapted to a particular habitat in eastern outcrops is replaced by another species of the same genus in the corresponding habitat in western outcrops. For example, Murdy and others (1970) described the competitive replacement of Talinum mengesii by T. teretifolium, which appear to occupy the same niche within granite outcrop communities.

In line with the general principles of island biogeography, the number of endemics present on a given granite outcrop is determined by factors including the size of the outcrop, proximity to the nearest outcrop, outcrop age, and degree of recent disturbance (Wyatt and Fowler, 1977). Dispersal capabilities of individual taxa also play an important role in distribution patterns of granite outcrop plants. In a genetic analysis of Minuartia uniflora, Wyatt and others (1992) noted unusually low genetic similarity between populations, suggesting that "pollen and seed dispersal between outcrop populations [of $M$. uniflora] is negligible" resulting in very low gene flow between populations that have an "island-like distribution" on granite outcrops across the species range. Houle (1990) presented concurrent evidence about overall species diversity for soil islands within a single outcropshowing a strong negative correlation between species richness of soil islands and the distance to the closest uphill island community - and suggested that the stress regime in early seral stages may be inhospitable to seedling germination, thus limiting immigration and gene flow and acting as a barrier to dispersal from one soil island to another. The geographic ranges of the aquatic endemics are particularly restricted because their aquatic habitat, available on some outcrops in Alabama, Georgia, and South Carolina, is generally not found farther north in the Piedmont (Wyatt and Fowler, 1977). Thus, distributions of taxa such as A. pusillus may be limited by habitat suitability and also by dispersal limitations (Hilton and Boyd, 1996).

Piedmont granite outcrops also provide habitat to a number of species with disjunct distributions and those with ranges that extend into the outcrops from nearby provinces. These outcrops allow range extensions for some Coastal Plain species (such as Packera tomentosa and Utricularia juncea) by providing moist, sandy habitats in outcrop seepage areas comparable to those available in the Coastal Plain, and for some mountain species (such as Saxifraga michauxii) for which populations along the eastern limit of the range are clustered in granite outcrops (Wyatt and Fowler, 1977). Habitat in Piedmont granite outcrops has also extended the ranges for Pleurochaete squarrosa, a moss previously thought to be restricted to calcareous substrates in the Interior Low Plateaus and Valley and Ridge Physiographic Provinces, and for Pleurozium schreberi, a boreal moss native to higher elevations in the Appalachian Mountains (Wyatt and Stoneburner, 1982). A few occurrences of Draba aprica in the Piedmont of Georgia and South Carolina are present in granite outcrops, disjunct from the Interior Highlands of Missouri, Arkansas, and Oklahoma (Quarterman and others, 1993). Other taxa exhibit more profound disjunctions. These include Cladina evansii, a type of lichen disjunct by approximately 200 miles (about 320 kilometers) from its population center in the sandhills region of the Atlantic Coastal Plain (Wyatt and Stoneburner, 1982). A population of Pellaea wrightiana-a rare fern native to the southwestern United States-is found on Piedmont granite outcrops, representing a disjunction of more than 1,000 miles (more than 1,500 kilometers). Additionally, Piedmont granite outcrops support taxa, such as Lotus unifoliolatus var. helleri, that are the only eastern members of taxonomic groups otherwise belonging to western North America (McVaugh, 1943; Walters and Wyatt, 1982).

The presence of endemic and disjunct plant taxa in granite outcrops is related to the particular abiotic stress regime of outcrop environments (Quarterman and others, 1993). Endemics generally are obligate heliophytes and are restricted to granite outcrops primarily due to lack of competitive ability in mesic environments rather than because of adaptation to rock substrate chemistry or genetic factors (Baskin and Baskin, 1988; Shure, 1999). Granite outcrop endemics have evolved an array of adaptations to cope with thin soils, xeric or highly variable hydrologic conditions, extreme temperature fluctuation, and intense solar irradiation. For example, Schoenolirion croceum has a deeply buried corm; Packera tomentosa has a deep root system and woody underground stem; Talinum teretifolium is a succulent that is capable of highly efficient water storage; and Tradescantia hirsuticaulis 

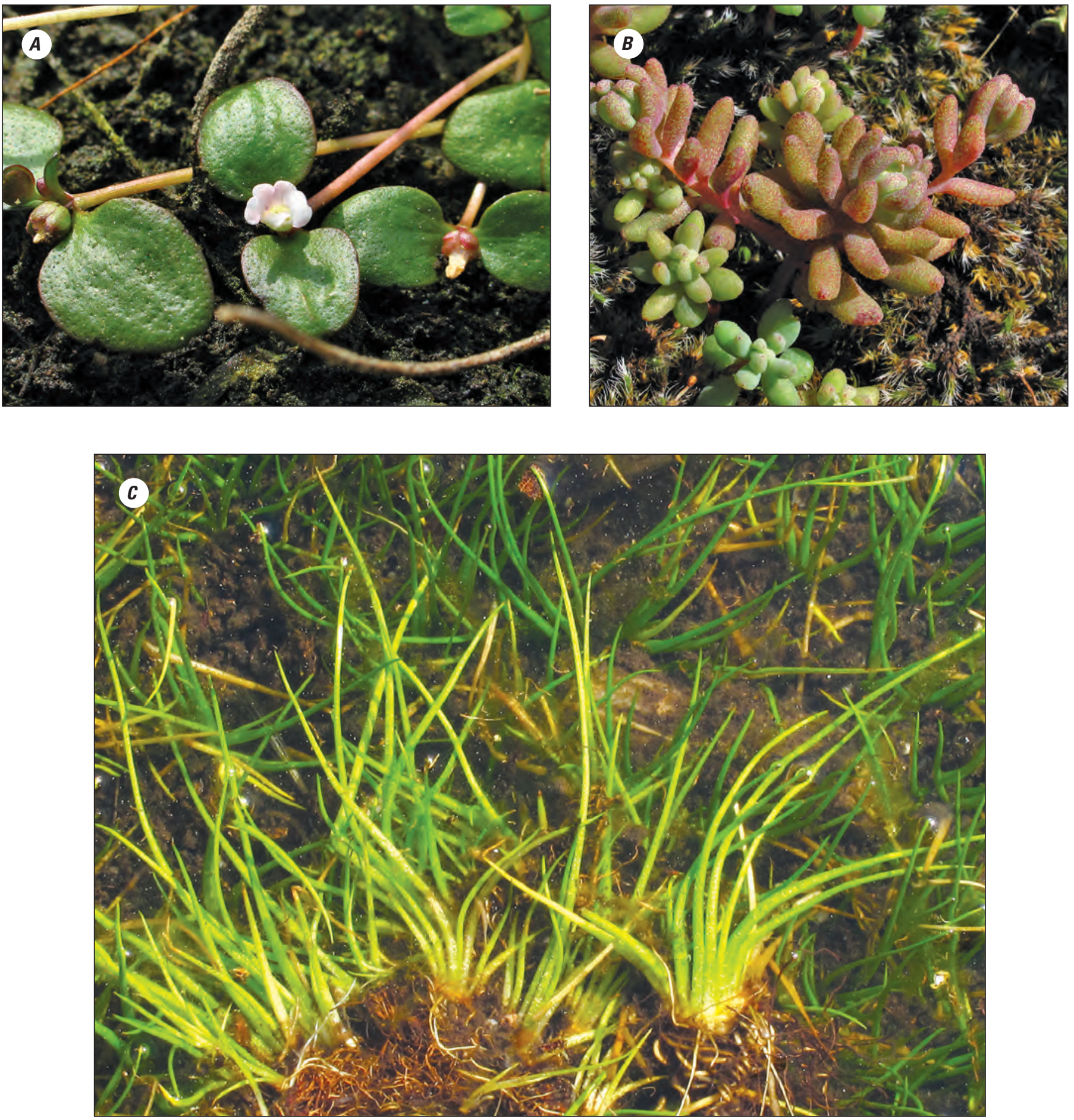

Figure B-6. Characteristic plant taxa of Piedmont granite outcrops, $A$, Amphianthus pusillus, Davidson-Arabia Mountain Nature Preserve, Dekalb County, Georgia; $B$, Sedum pusillum, Heggie's Rock Preserve; $C$, Isoetes tegetiformans, Heggie's Rock Preserve, Columbia County, Georgia. Photographs by Alan M. Cressler, U.S. Geological Survey. 
is covered with light-colored hairs that reflect light and limit water loss (Burbanck and Platt, 1964; Tate, 2005). The life form of granite outcrop taxa (the degree of exposure of their perennating tissues) also reflects adaptation to harsh environmental conditions. Granite outcrop species are much more likely to be therophytes (having their only perennating tissues in the seed, an adaptation that promotes tolerance to drought and heat) than the surrounding Piedmont flora, and in fact, their life-form spectra more closely approximate desert areas such as Death Valley, California (Phillips, 1982). Based on physiology, habitat, and evolved tolerance to a particular stress regime, granite outcrop endemics have been compared to and associated with species found in deserts of the southwestern United States and northern Mexico (McVaugh, 1943; Braun, 1955; Tate, 2005). The three species endemic to persistent pools have unique adaptations to their particular stress regime. Isoetes melanospora and Isoetes tegetiformans use an unusual photosynthetic pathway similar to crassulacean acid metabolism photosynthesis (CAM photosynthesis) (Shure, 1999). Amphianthus pusillus has submerged and floating leaves, and bears its flowers on elongated floating stems and also submerged at the plant base where they are cleistogamous (self-pollinating) (Hilton and Boyd, 1996; Shure, 1999). A. pusillus is a winter annual, germinating when water levels in pools are typically highest and completing its life cycle very quickly (Hilton and Boyd, 1996). Although these adaptations to abiotic stress are particularly noteworthy for endemic taxa, abundant and geographically widespread taxa also have been shown to display heightened drought tolerance in their granite outcrop populations (Chapman and Jones, 1975).

\section{Animal Taxa of Conservation Concern}

Piedmont granite outcrops provide habitat to a number of arthropods of regional and global conservation concern. Trimerotropis saxatilis (lichen grasshopper), a G3-ranked species apparently restricted to rock outcrop and glade ecosystems, is an important and characteristic herbivore in Piedmont granite outcrops (Duke and Crossley, 1975). Other regionally rare arthropods present in granite outcrops include Pardosa lapidicina (the lichen spider) and Anisomorpha ferruginea 5 (a walking stick) (Quarterman and others, 1993). Dendrocephalus lithaca (the Stone Mountain fairy shrimp) was described in the 1950s from depressions on the summit of Stone Mountain in Georgia; however, this branchipod has not been reported in several decades and is suspected to be extinct (Rogers and others, 2004). Animals inhabiting granite outcrops also display certain adaptations to heightened abiotic stress. For example, soil nematodes exhibit anhydrobiosis - an ametabolic, inactive state coupled with a coiled morphology - in granite outcrop soils where desiccation is a major stress factor (Austin and others, 2009).

\footnotetext{
${ }^{5}$ Species name according to the Integrated Taxonomic Information System (2015).
}

\section{Conservation Considerations}

Conservation of Piedmont granite outcrops and the biodiversity they support involves several key considerations. These include an assessment of current and historical threats, an evaluation of existing conservation strategies, and an identification of gaps in scientific knowledge such as those concerning possible ecological effects of climate change.

\section{Threats to Ecosystem Integrity}

The Piedmont Physiographic Province is one of the most densely populated regions in the United States, resulting in threats to granite outcrop ecosystems - especially those on private land - from suburban development, outdoor recreation, and the dumping of refuse (Tate, 2005). Some granite outcrops have been destroyed by the creation of reservoirs (Wyatt and Stoneburner, 1982; Quarterman and others, 1993). Many surviving granite outcrops have been adversely affected by logging operations, quarrying for granite, and livestock grazing (McVaugh, 1943; Keever and others, 1951; Burbanck and Platt, 1964; Quarterman and others, 1993; Shure, 1999; Tate, 2005). Granite outcrops make attractive recreational destinations, and thus are especially vulnerable to physical destruction from trampling (Wyatt and Fowler, 1977; Burbanck and Phillips, 1983; Shure, 1999; Belden and others, 2003). Air pollution and acid rain have also been mentioned as threats to granite outcrop species, especially bryophytes (Quarterman and others, 1993; Tate, 2005). Woody encroachment within ecotones of granite outcrops - possibly facilitated by fire suppression and the establishment of exotic invasive species - has also been suggested as a threat to ecosystem integrity (Caspary and Affolter, 2012).

\section{Conservation Strategies}

Throughout the Piedmont, a number of state, Federal, and private natural areas and preserves have been established to protect granite outcrop communities (see Quarterman and others [1993] for a list of sites). The fact that several endemic species of granite outcrops are federally listed as endangered or threatened may provide some additional habitat protection on private land (Shure, 1999). Conservation approaches generally focus on protecting granite outcrops from physical destruction (such as from quarrying or recreation) and educating the public about their ecological importance. In a few preserves, prescribed fire has been used as a management tool to combat woody encroachment by invasive species at outcrop-forest ecotones (Caspary and Affolter, 2012). 


\section{Knowledge Gaps}

Some aspects of granite outcrop community structure have been well studied, particularly the patterns of succession for soil island communities (Oosting and Anderson, 1939; McVaugh, 1943; Keever and others, 1951; Burbanck and Platt, 1964; Wyatt and Fowler, 1977; Burbanck and Phillips, 1983; Houle and Phillips, 1988, 1989; Houle, 1990). Little is known about other important dynamics of granite outcrop community structure, however, including plant relationships with arthropod herbivores and pollinators (Quarterman and others, 1993). In some cases, the taxonomic relationships among granite outcrop species and between them and the surrounding vegetation need clarification (Tate, 2005). Additionally, the mechanisms and resilience capacities of plant species in response to climatic stressors have not been fully explored, such that the effects of changing abiotic stress on particular taxa of conservation concern cannot currently be quantified (Shure, 1999). Research on ecological effects of abiotic stress factors is needed. For example, droughts could be used to examine differential effects on endemic versus nonendemic taxa or among plants occupying different microenvironments within granite outcrops (Amyx, 2015).

\section{Possible Ecological Effects from Climate Change}

Research is generally lacking concerning the effects of climate change on Piedmont granite outcrop species. Such effects could plausibly include changes to hydrologic regimes, temperature changes, and interactive effects with known biotic factors such as invasive species. Ibáñez and others (2006) predicted that the Piedmont will experience increased aridity from climate change, possibly resulting in a dramatic restructuring of forest communities in the region. If this were to occur, the different community types sustained by various microhabitats within granite outcrops would likely be affected in different ways. Microhabitats that have historically been dry to xeric (including bare rock surfaces and dry depressions) would presumably experience stress regime intensification, with unknown consequences for their associated rare taxa and succession dynamics. Zones with widely fluctuating hydrologic conditions, such as periodically wet depressions, would likely experience reductions in hydroperiod that could lead to restructuring of plant communities. Persistent pools might shift from being semipermanently inundated to having increased frequency of complete drying, which would be expected to degrade habitat for the rare semiaquatic endemics Isoetes melanospora, I. tegetiformans, and Amphianthus pusillus. Davenport (2007) highlighted the importance of precipitation seasonality and suggested that A. pusillus "would survive as long as [its] life cycles coincide with available spring rainfall." Microhabitats such as soil islands and seepage areas with hydrologic conditions that have historically been relatively mesic might shift toward drier conditions with associated restructuring of community composition. Hypotheses such as these are necessarily speculative in the absence of large-scale empirical examinations of climate-change-driven effects on Piedmont granite outcrop ecology. The exact nature of community restructuring in these outcrop communities and the implications for rare plant conservation are impossible to predict with any certainty. An additional unknown is how climate change might affect disturbance regimes on granite outcrops, such as fire, tree falls, exfoliation enabled by freeze-thaw cycles, and the dislodging of vegetation mats during storm events.

As abiotic stress regimes change, the microhabitat requirements and dispersal limitations of many rare taxa associated with Piedmont granite outcrops may restrict their ability to migrate to new geographic areas, such that simple climate-envelope models based on poleward shifts in suitable climate will be inadequate to describe the influences of climate change on the geographic distributions of these taxa (Noss and others, 1995; Ibáñez and others, 2006). Given such barriers to range-shifting, adaptations such as phenophase change might be expected to occur as granite outcrop taxa cope with seasonal shifts in temperature and precipitation. One possible approach for detecting such effects could include the resampling of well-studied communities and comparison to earlier published data. For example, Burbanck and Platt (1964) produced a chart of seasonal timing for various granite outcrop species indicating months of vegetative growth, flowering, and fruiting. A resampling of those outcrops similarly focused on these phenological indicators might demonstrate whether any changes have occurred between the 1960s and the present.

Some recent discussions of biodiversity conservation in the face of rapid climate change have focused on preserving regional diversity of geologic, edaphic, and topographic conditions, an approach sometimes referred to as "conserving the geophysical stage" (Game and others, 2010; Anderson and Ferree, 2010). Piedmont granite outcrops exist in stark contrast to the surrounding landscape and provide regionally unique environments for rare taxa, such that their conservation would certainly be an important component to any regional climatechange-mitigation strategies seeking to maintain such diversity of the physical environment. 


\section{References}

Amyx, H., 2015, Helianthus porteri (Porter's sunflower) survives drought at Rocky Face Mountain, accessed November 17, 2015, at https://bwwellsassociation.wordpress.com/2015/09/30/helianthus-porteri-porters-sunflowersurvives-drought-at-rocky-face-mountain/.

Anderson, M., and Ferree, C., 2010, Conserving the stageClimate change and the geophysical underpinnings of species diversity: PLOS ONE, v. 5, no. 7, p. e11554.

Austin, E., Semmens, K., Parsons, C., and Treonis, A., 2009, Granite rock outcrops-An extreme environment for soil nematodes?: Journal of Nematology, v. 41, no. 1, p. 84-91.

Bailey, C., and Coe, F., 2001, The vascular flora of the riparian zones of the Clear Fork River and the New River in the Big South Fork National River and Recreation Area (BSFNRRA): Castanea, v. 66, no. 3, p. 252-274.

Baskin, J., and Baskin, C., 1988, Endemism in rock outcrop plant communities of unglaciated eastern United StatesAn evaluation of the roles of the edaphic, genetic and light factors: Journal of Biogeography, v. 15, no. 5, p. 829-840.

Belden, A., Chazal, A., and Hobson, C., 2003, A natural heritage inventory of fourteen headwater sites in the Dragon Run Watershed: Richmond, Va., Virginia Department of Conservation and Recreation.

Boom, B., 1982, Synopsis of Isoetes in the southeastern United States: Castanea, v. 47, no. 1, p. 38-59.

Braun, E., 1955, The phytogeography of unglaciated eastern United States and its interpretation: The Botanical Review, v. 21 , no. 6 , p. $297-375$.

Burbanck, M., and Phillips, D., 1983, Evidence of plant succession on granite outcrops of the Georgia Piedmont: American Midland Naturalist, v. 109, no. 1, p. 94-104.

Burbanck, M., and Platt, R., 1964, Granite outcrop communities of the Piedmont Plateau in Georgia: Ecology, v. 45, no. 2, p. 292-306.

Caspary, M., and Affolter, J., 2012, Using prescribed burning to restore granite rock outcrop ecotones in the Piedmont of the southeastern United States: Ecological Restoration, v. 30 , no. 3 , p. $228-236$.

Chapman, R., and Jones, S., 1975, Ecotypic differentiation in Andropogon virginicus (Gramineae): Bulletin of the Torrey Botanical Club, v. 102, no. 4, p. 166-171.

Davenport, L., 2007, Climate change and its potential effects on Alabama's plant life: Birmingham, Ala., Samford University, Vulcan Materials Center for Environmental Stewardship and Education.
Duke, K., and Crossley, D., 1975, Population energetics and ecology of the rock grasshopper, Trimerotropis saxatilis: Ecology, v. 56, no. 5, p. 1106-1117.

Fenneman, N., 1938, Physiography of the Eastern United States: New York, McGraw-Hill.

Fenneman, N., and Johnson, D., 1946, Physical divisions of the United States: U.S. Geological Survey map prepared in cooperation with the Physiographic Commission, scale $1: 7,000,000$.

Game, E., Groves, C., Andersen, M., Cross, M., Enquist, C., Ferdaña, Z., Girvetz, E., Gondor, A., Hall, K., Higgins, J., Marshall, R., Popper, K., Schill, S., and Shafer, S., 2010, Incorporating climate change adaptation into regional conservation assessments: Arlington, Va., The Nature Conservancy.

Hilton, J., and Boyd, R., 1996, Microhabitat requirements and seed/microsite limitation of the rare granite outcrop endemic Amphianthus pusillus (Scrophulariaceae): Bulletin of the Torrey Botanical Club, v. 123, no. 3, p. 189-196.

Houle, G., 1990, Species-area relationship during primary succession in granite outcrop plant communities: American Journal of Botany, v. 77, no. 11, p. 1433-1439.

Houle, G., and Phillips, D., 1988, The soil seed bank of granite outcrop plant communities: Oikos, v. 52, no. 1, p. 87-93.

Houle, G., and Phillips, D., 1989, Seed availability and biotic interactions in granite outcrop plant communities: Ecology, v. 70 , no. 5 , p. $1307-1316$.

Ibáñez, I., Clark, J., Dietze, M., Feeley, K., Hersh, M., LaDeau, S., McBride, A., Welch, N., and Wolosin, M., 2006, Predicting biodiversity change - Outside the climate envelope, beyond the species-area curve: Ecology, v. 87, no. 8 , p. 1896-1906.

Integrated Taxonomic Information System, 2015, The Integrated Taxonomic Information System, accessed October 5, 2015, at http://www.itis.gov.

Keever, C., 1957, Establishment of Grimmia laevigata on bare granite: Ecology, v. 38, no. 3, p. 422-429.

Keever, C., Oosting, H., and Anderson, L., 1951, Plant succession on exposed granite of Rocky Face Mountain, Alexander County, North Carolina: Bulletin of the Torrey Botanical Club, v. 78, no. 5, p. 401-421.

LeGrand, H., 1988, Cedar glades on diabase outcrops-A newly described community type: Castanea, v. 53 , no. 2 , p. $168-172$.

Leslie, K., and Burbanck, M., 1979, Vegetation of granitic outcroppings at Kennesaw Mountain, Cobb County, Georgia: Castanea, v. 44, no. 2, p. 80-87. 
Loehle, C., 2006, Endemic plant distributions in Eastern North America-Implications for conservation: Journal of Forestry, v. 104, no. 8, p. 415-418.

Marcinko, S., 2007, Pattern and process in rare plant conservation-An assessment of the southeastern U.S.: Chapel Hill, N.C., University of North Carolina, Masters Thesis.

Matthews, J., and Murdy, W., 1969, A study of Isoetes common to the granite outcrops of the southeastern Piedmont, United States: Botanical Gazette, v. 130, no. 1, p. 53-61.

McVaugh, R., 1943, The vegetation of the granitic flat-rocks of the southeastern United States: Ecological Monographs, v. 13 , no. 2, p. 119-166.

Murdy, W., Johnson, T., and Wright, V., 1970, Competitive replacement of Talinum mengesii by T. teretifolium in granite outcrop communities of Georgia: Botanical Gazette, v. 131 , no. 3, p. 186-192.

Noss, R., LaRoe, E., and Scott, J., 1995, Endangered ecosystems of the United States-A preliminary assessment of loss and degradation: Washington, D.C., U.S. Department of the Interior.

Oosting, H., and Anderson, L., 1937, The vegetation of a barefaced cliff in western North Carolina: Ecology, v. 18, no. 2, p. 280-292.

Oosting, H., and Anderson, L., 1939, Plant succession on granite rock in eastern North Carolina: Botanical Gazette, v. 100 , no. 4 , p. $750-768$.

Phillips, D., 1981, Succession in granite outcrop shrubtree communities: American Midland Naturalist, v. 106, p. 313-317.

Phillips, D., 1982, Life-forms of granite outcrop plants: American Midland Naturalist, v. 107, no. 1, p. 206-208.

Quarterman, E., Burbanck, M., and Shure, D., 1993, Rock outcrop communities - Limestone, sandstone, and granite, in Biodiversity of the southeastern United States-Upland Terrestrial Communities: New York, John Wiley and Sons, Inc., p. 35-86.

Reinhard, R., and Ware, S., 1989, Adaptation to substrate in rock outcrop plants - Interior Highlands Talinum (Portulacaceae): Botanical Gazette, v. 150, no. 4, p. 449-453.

Rogers, D., Jensen, J., and Floyd, T., 2004, Eubranchipus stegosus $\mathrm{n}$. sp.(Crustacea: Anostraca), a bizarre new species of fairy shrimp from the southeastern United States: Hydrobiologia, v. 528, p. 201-207.
Schmalzer, P., Patrick, T., and DeSelm, H., 1985, Vascular flora of the Obed Wild and Scenic River, Tennessee: Castanea, v. 50, no. 2, p. 71-88.

Shure, D., 1999, Granite outcrops of the southeastern United States, in Anderson, R., Fralish, J., and Baskin, J., eds., Savannas, barrens, and rock outcrop plant communities of North America: New York, Cambridge University Press, p. 99-118.

Shure, D., and Ragsdale, H., 1977, Patterns of primary succession on granite outcrop surfaces: Ecology, v. 58, p. 993-1006.

Snyder, J., and Wullstein, L., 1973, Nitrogen fixation on granite outcrop pioneer ecosystems: Bryologist, v. 76, no. 1, p. 196-199.

Spaulding, D., 2013, Key to the dodders (Cuscuta, Convolvulaceae) of Alabama and adjacent states: Phytoneuron, v. 74 , p. $1-15$.

Tate, S., 2005, Effects of stratification on the germination of six Piedmont rock outcrop species and development of a model Piedmont rock outcrop habitat garden: Athens, Ga., University of Georgia, Masters Thesis.

U.S. Geological Survey, National Gap Analysis Program, 2011, Land cover data portal, accessed December 2015 at http://gapanalysis.usgs.gov/gaplandcover/data/download/.

Walters, T., and Wyatt, R., 1982, The vascular flora of granite outcrops in the Central Mineral Region of Texas: Bulletin of the Torrey Botanical Club, v. 109, no. 3, p. 344-364.

Wyatt, R., Evans, E., and Sorenson, J., 1992, The evolution of self-pollination in granite outcrop species of Arenaria (Caryophyllaceae). VI. Electrophoretically detectable genetic variation: Systematic Botany, v. 17, no. 2, p. 201-209.

Wyatt, R., and Fowler, N., 1977, The vascular flora and vegetation of the North Carolina granite outcrops: Bulletin of the Torrey Botanical Club, v. 104, no. 3, p. 245-253.

Wyatt, R., and Stoneburner, A., 1982, Range extensions for some cryptogams from granite outcrops in Alabama: Bryologist, v. 85, no. 4, p. 405-409. 



\section{Chapter C. Limestone Cedar Glades}

\section{Introduction}

Limestone cedar glades (fig. C-1) are edaphic climax ecosystems, characterized by herbaceous angiosperms and cryptogams growing in thin soil, with areas of exposed limestone bedrock, rock pavement, gravel, cobbles, and (or) flagstone (Quarterman and others, 1993; Baskin and Baskin, 2003; Baskin and others, 2007b). Because the perimeters of these rock outcrops are typically inhabited by Juniperus virginiana (eastern redcedar), they are commonly called cedar glades (Baskin and others, 1968). Cedar glade vegetation is dominated by $\mathbf{C}_{4}$ summer annual grasses (for example, Sporobolus vaginiflorus) and $\mathbf{C}_{3}$ forbs, which may be winter or summer annuals or perennials, with sparse shrub and tree cover (Baskin and Baskin, 1999). In microhabitats of cedar glades where soil is insufficiently thick to support vascular plants, important community constituents are mosses, cyanobacteria such as Nostoc commune ${ }^{6}$, and fruticose, foliose, and crustose lichens (Quarterman, 1950b; Baskin and others, 2007b). Some limestone cedar glades contain distinct zonal communities that are seasonally saturated, support specialized associations of hydrophytic vegetation, and arguably meet the standards for delineation as wetlands (U.S. Army Corps of Engineers, 2010; Taylor and Estes, 2012). Based on their high degree of endemism, limestone cedar glades are considered to be among the most botanically unique ecosystems in the southeastern United States (Somers and others, 1986; Estill and Cruzan, 2001).

\footnotetext{
${ }^{6}$ Species name according to the Integrated Taxonomic Information System (2015).
}

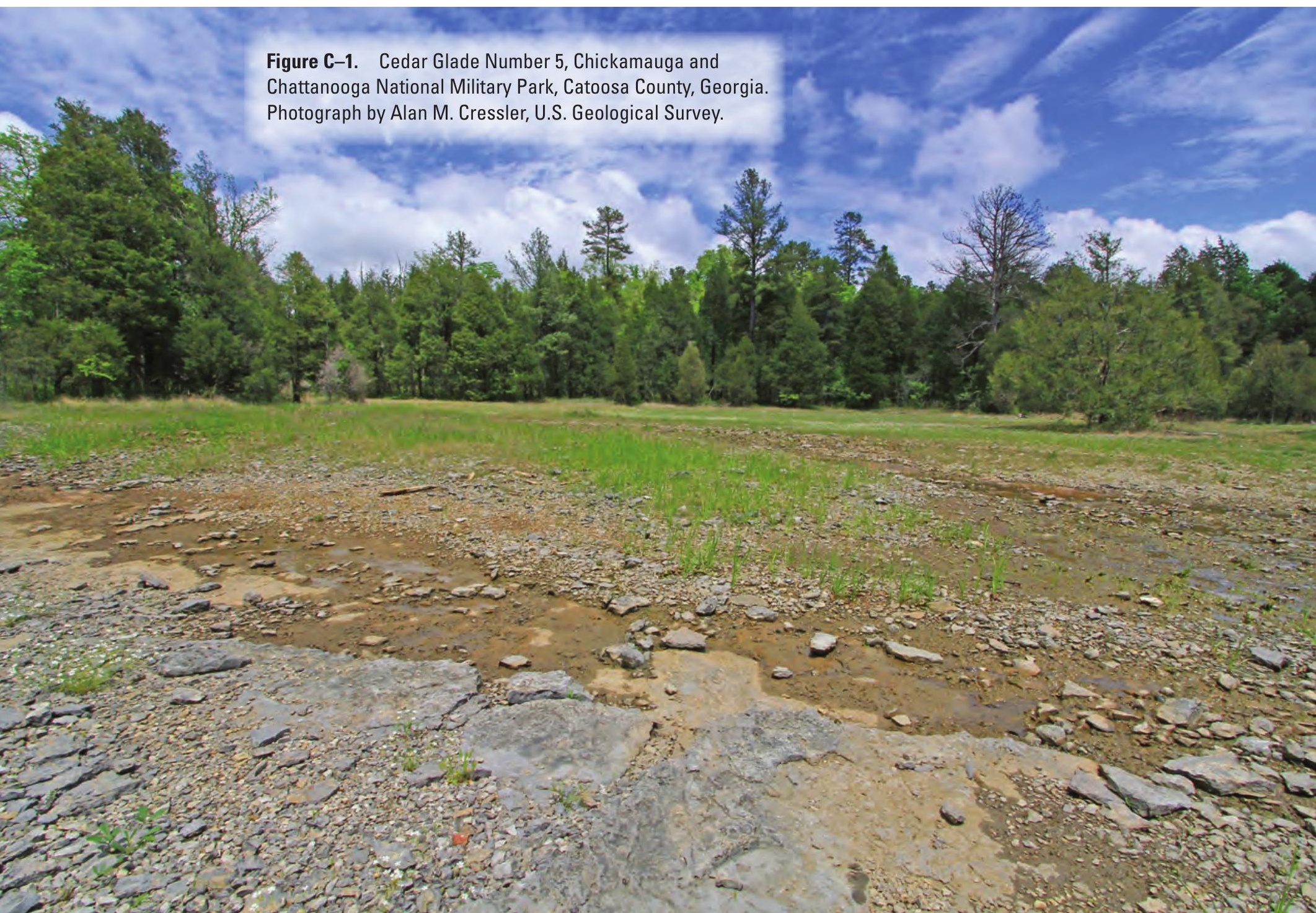




\section{Geographic Range}

Limestone cedar glades are present in three physiographic provinces of the southeastern United States (the Interior Low Plateaus, Appalachian Plateaus, and Valley and Ridge; fig. C-2) in regions of five States (the Outer Bluegrass and Pennyroyal Plain regions of central Kentucky; "The Cedars" area in Lee County in extreme southwestern Virginia; the
Western Valley, Nashville Basin, and Valley and Ridge regions of Tennessee; the Tennessee Valley, Little Mountain, Moulton Valley, and Sequatchie Valley regions of northern Alabama; and the Valley and Ridge region of extreme northwestern Georgia; Baskin and Baskin, 1999, 2003). The greatest concentration and best developed examples of limestone cedar glades are within the Cumberland River and Duck River drainage basins of the Inner Nashville Basin of Tennessee,

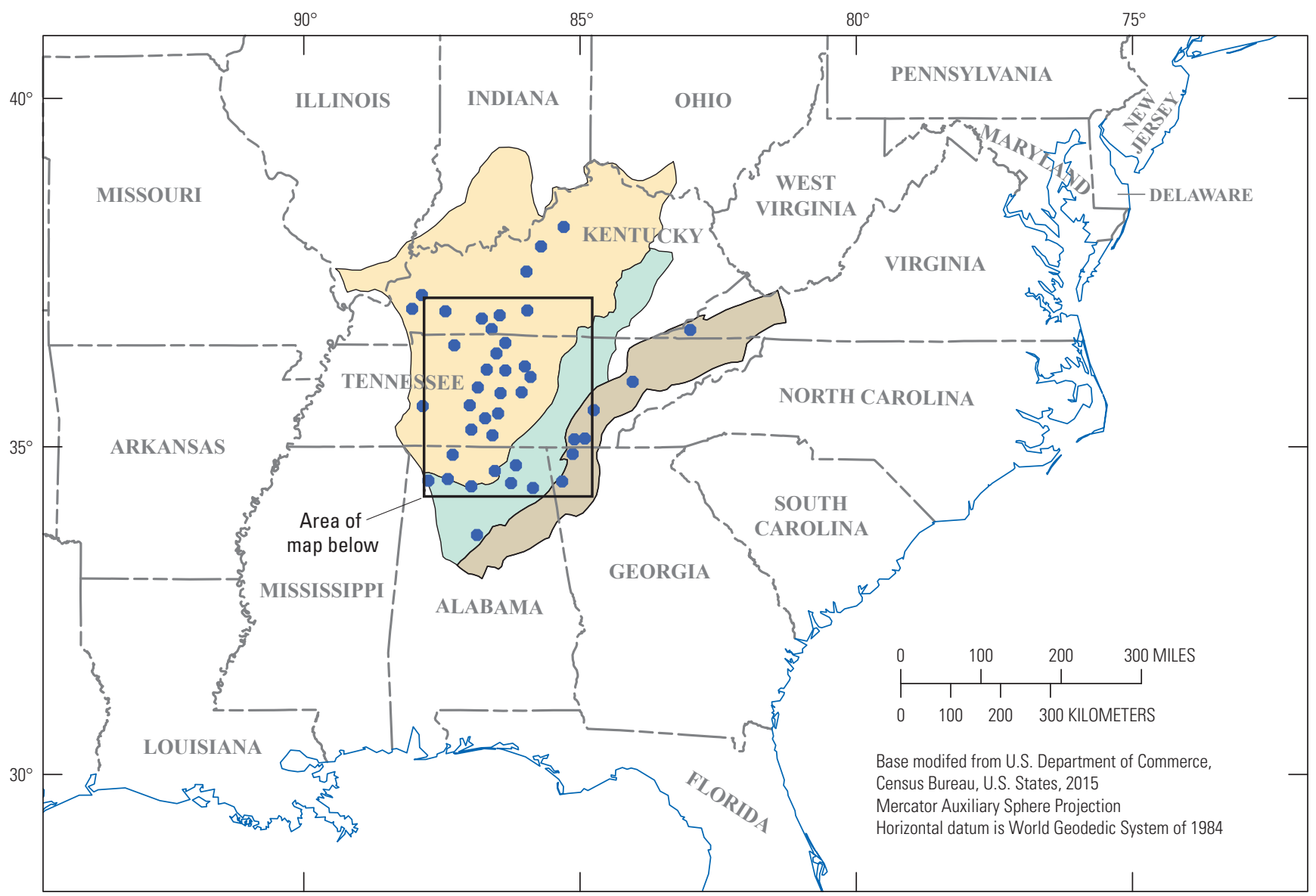

\section{EXPLANATION}

Physiographic division-From Fenneman and Johnson (1946) and U.S. Department of Agriculture (2015)

Interior Low Plateaus Physiographic Province

Cumberland Plateau section of Appalachian Plateaus Physiographic Province

Tennessee section of Valley and Ridge Physiographic Province

Inner Nashville Basin subsection

Outer Nashville Basin subsection

Nashville Basin Limestone Glade and Woodland Ecological System-Modified from U.S. Geological Survey (2011)

- Selected occurrences of limestone cedar gladesModified from Quarterman and others (1993)

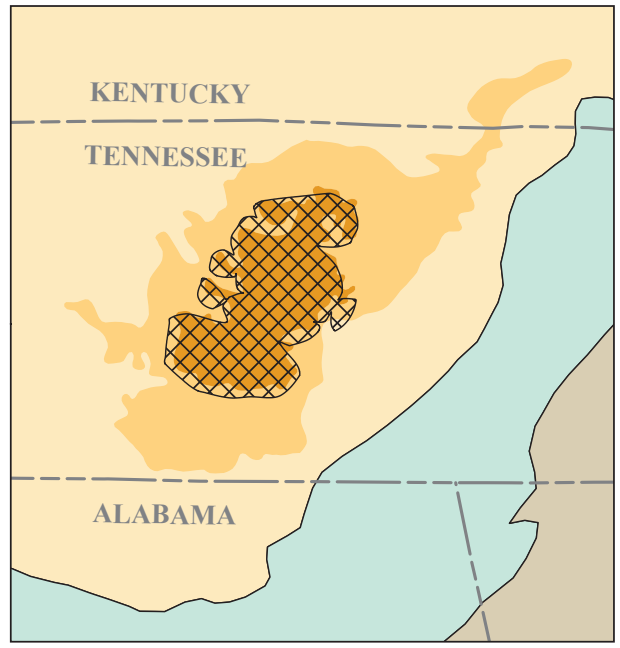

Figure C-2. General geographic distribution of limestone cedar glades. 
corresponding to the Nashville Basin Limestone Glade and Woodlands ecological system according to the International Terrestrial Ecological Systems Classification (ITESC). This region also supports the greatest number of cedar glade endemic plant taxa, with the second-highest concentration of endemics found in northern Alabama (Harper, 1926; Baskin and others, 1995; Baskin and Baskin, 1999; Baskin and Baskin, 2003; Sutter and others, 2011).

\section{Physical Geography}

Limestone cedar glades develop on rock outcrops of level or moderate slope (5-15 percent) at an average elevation of 600 feet (about 180 meters) on thinly bedded limestone or dolomite, typically of Ordovician, Silurian, or Mississippian age (Harper, 1926; Quarterman, 1950a; Baskin and Baskin, 1999). In the Inner Nashville Basin, limestone cedar glades are present primarily on the Talbott-Rock Outcrop and the TalbottGladeville-Barfield-Rock Outcrop soil associations on limestones of Ordovician age of the Stones River Group (Baskin and Baskin, 2004). In the Moulton Valley of northern Alabama, cedar glades are present primarily on Colbert and Talbott soil series on the Bangor Limestone (Baskin and others, 1995). At some sites, the underlying limestone bedrock is extensively cracked, creating a patchwork habitat of thin soil above intact areas of bedrock surrounded by linear zones of relatively deep soil in crevices that are in some places wide enough to support $J$. virginiana trees (Quarterman, 1950a, b; Baskin and others, 2007a). Figure $\mathrm{C}-3$ shows an example of vegetation patterns reflecting bedrock fissures in a limestone cedar glade.

Cedar glades are typically associated with lithic mollisols (rendolls and udolls) and alfisols, and the limestone parent material contributes to greater alkalinity and calcium content relative to surrounding forest soils (Mann and others, 1999; Baskin and others, 2007a). Cedar glade soils characteristically lack a B horizon and have been classified as stony loams (Quarterman, 1950b) and as flaggy silty clay loams (Baskin and Baskin, 1999, 2004). Various researchers have characterized the soil thickness of cedar glades using slightly different ranges; however, all researchers agree that, in general, cedar glade soils are less than 12 inches (less than 30 centimeters) in thickness (Quarterman, 1950a; Baskin and Baskin, 1977; Anderson and others, 1999; Baskin and Baskin, 2003; Baskin and others, 2007a). Spatial gradients in soil depth are associated with gradients in a number of ecologically relevant soil properties and processes. For example, increasing soil depth is associated with decreasing $\mathrm{pH}$, increasing organic matter content, increasing sand-to-silt ratio (Cartwright, 2014), and increasing soil respiration rates (Cartwright and Hui, 2014).

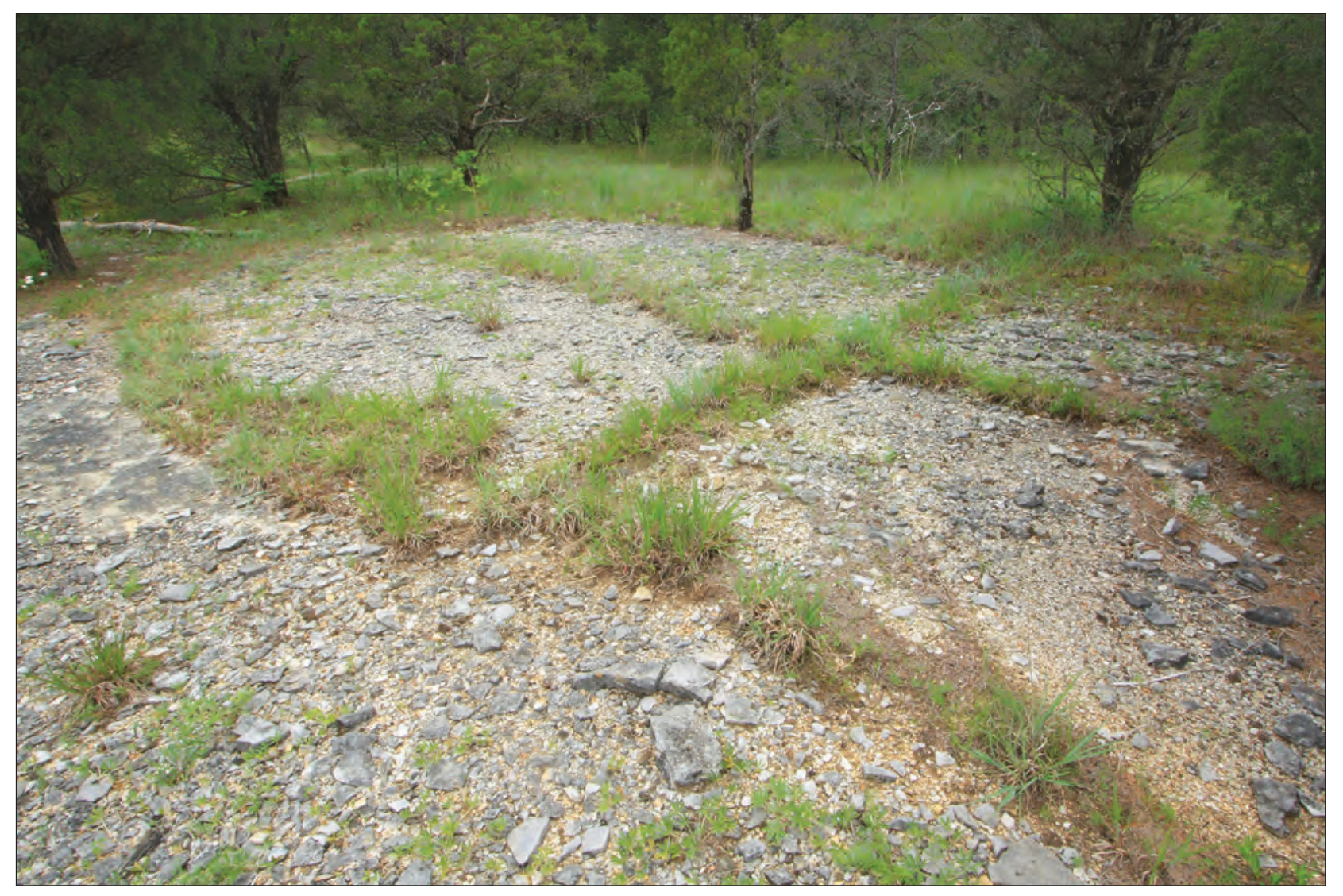

Figure C-3. Grass-filled cross joint, Chickamauga and Chattanooga National Military Park, Catoosa County, Georgia. Photograph by Alan M. Cressler, U.S. Geological Survey. 


\section{Stress and Disturbance Regimes}

The stress regime of limestone cedar glades is characterized by thin soil, high insolation, high soil temperatures in summer, and widely fluctuating soil moisture availability (Quarterman, 1989; Baskin and others, 1995; Baskin and Baskin, 2003). Seasonally high temperatures at the soil surface are especially common in unshaded zones with very thin soil in glade interiors. Temperatures near the soil surface have been recorded as high as 43 degrees Celsius $\left({ }^{\circ} \mathrm{C}\right)$ (Dubois, 1993), $50{ }^{\circ} \mathrm{C}$ (Baskin and Baskin, 1999), and $50.5^{\circ} \mathrm{C}$ (Freeman, 1933). The combination of high temperatures and thin soils in summer can result in seasonally dry to xeric soil conditions. For example, working primarily during the growing season, Freeman (1933) reported soil water content levels below the wilting coefficient 11 times between mid-June and late October. Spatial heterogeneity in canopy coverage and soil thickness commonly produce gradients of moisture availability. Based on five sites described as "gravel, grass, shrub, shrub-cedar and cedar-hardwood," Martin and Sharp (1983) reported a decrease in available soil moisture along that gradient from forest to open glade. Seasonal water stress in cedar glades is commonly reflected in vegetation composition. Some plant taxa use the $\mathrm{C} 4$ photosynthetic pathway (for example, Andropogon virginicus, Sporobolus vaginiflorus, Cyperus squarrosus, some Euphorbia species, and some Panicum species) or the crassulacean acid metabolism (CAM) pathway (for example, Manfreda virginica and Opuntia humifusa), indicating adaptation to xeric conditions (Baskin and Baskin, 1981; Eickmeier, 1986).

Several investigations have also noted components of cedar glade vegetation suggestive of adaptation to wet or saturated soil conditions (for example, Carex species, Isoetes butleri, Eleocharis bifida, and Schoenolirion croceum) (Freeman, 1933; Rollins, 1997; Baskin and others, 2007b). Drainage of cedar glades occurs primarily as sheet flow, which often drains into subterranean cave systems (Quarterman and others, 1993). Drainage ability may be highly variable spatially, depending on location relative to drainage pathways such as joints in limestone strata. Zones of lateral seepage and topographic depressions above relatively impermeable bedrock are commonly associated with seasonally saturated or inundated conditions from winter to early spring (fig. C-4), when precipitation is relatively high and evapotranspiration is relatively low (Taylor and Estes, 2012; Nelson and others, 2013). Winter-annual taxa, including a number of hydrophytic taxa, complete their life cycles during this season. Quarterman (1950a) emphasized the importance of widely fluctuating soil water content to the stress regime of cedar glades, asserting that "the occurrence of both wet and dry extremes must limit the number of species capable of living in glade areas."

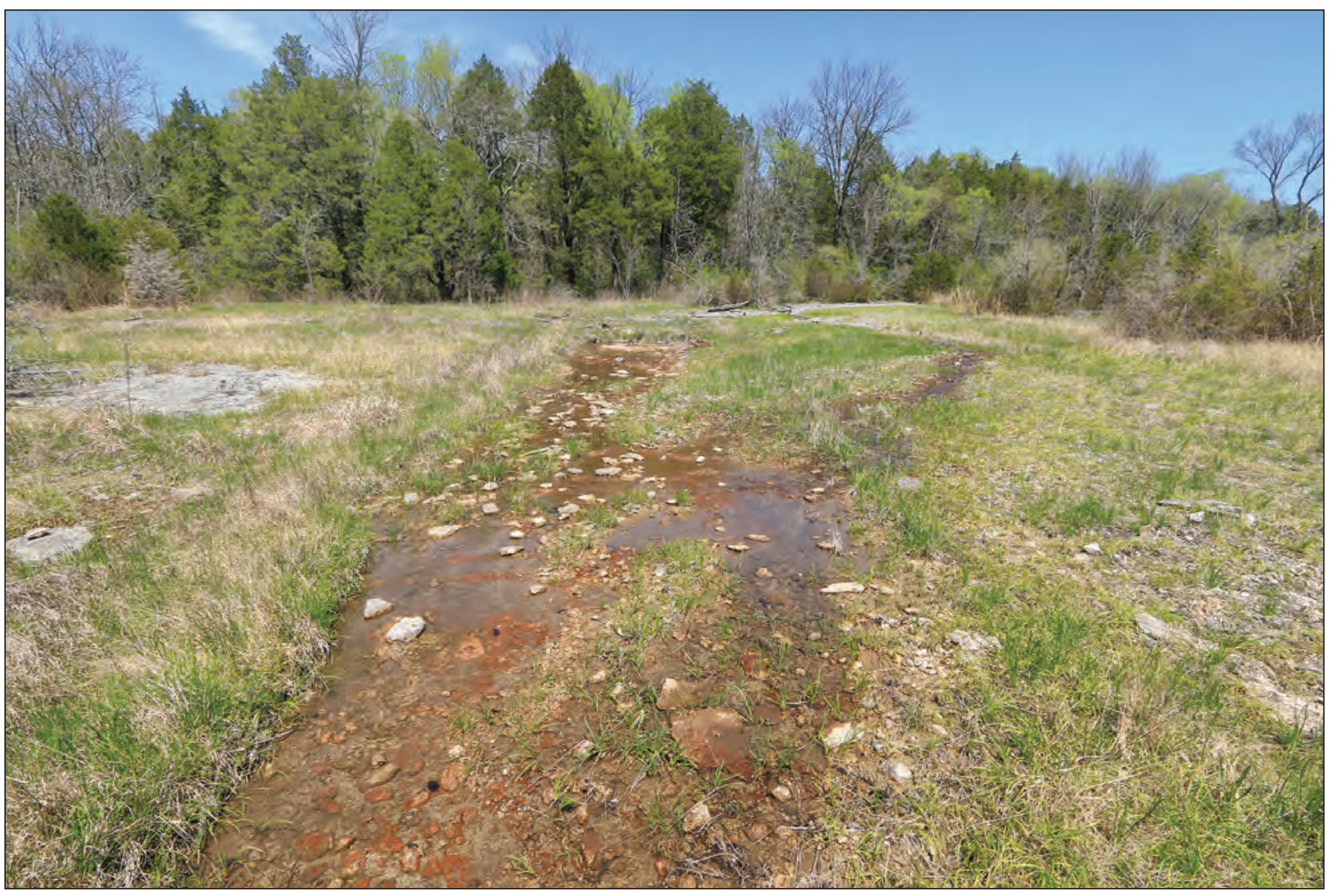

Figure C-4. Standing water, Flat Rock Cedar Glades and Barrens State Natural Area, Rutherford County, Tennessee. Photograph by Alan M. Cressler, U.S. Geological Survey. 


\section{Community Types and Vegetation Dynamics}

Relatively high abiotic stress levels, combined with low biomass and low levels of competition for light, generally mean that plant community structure within glade interiors is influenced more by stress tolerance than by competitive displacement (Quarterman, 1950b; Walck and others, 2001; Norton, 2010). In particular, vegetation patterns in limestone cedar glades commonly reflect gradients in soil depth (Freeman, 1933; Quarterman, 1950b; Norton, 2010). As a result, vegetation density can be highly spatially variable, ranging from zones nearly devoid of vascular plants in the vicinity of exposed bedrock to thickly vegetated zones in areas of deeper soil (Quarterman, 1950b; Nordman, 2004). Shrub communities characterized by Forestiera ligustrina, Rhus aromatica, and small Juniperus virginiana trees commonly develop at glade margins and along fissures (Quarterman, 1989). The sub-climax or climax forest communities that are found on glade-forming soils of the Inner Nashville Basin and that surround cedar glades are typically dominated by J. virginiana, Fraxinus americana, Carya ovata, and Quercus muehlenbergii (Adams and others, 2012). In addition to vascular plant species, cedar glades provide habitat to a number of fruticose and foliose lichens and to communal groups of cyanobacteria including Oscillatoria, Stigonema, Scytonema, and Nostoc species (Quarterman, 1950b; Mahr and Mathis, 1981; Somers and others, 1986; Quarterman, 1989).

Various researchers have used differing classification schemes to describe the communities present in cedar glades (Baskin and others, 2007b). Furthermore, the scale used for classification affects community classification outcomes, such that small-scale classification primarily reflects microhabitat differences, whereas larger-scale classification reflects vegetation differences between glades (Rollins, 1997). Working in the Inner Nashville Basin of Middle Tennessee, Somers and others (1986) delineated seven plant communities in cedar glades by using cluster analysis: Panicum capillare, foliose lichen, Nostoc commune-Sporobolus vaginiflorus, and Dalea gattingeri (xeric communities); and Sporobolus vaginiflorus, Pleurochaete squarrosa, and Panicum flexilePleurochaete squarrosa-Sporobolus vaginiflorus (sub-xeric communities). The four xeric communities generally were found on soils less than 2 inches (about 5 centimeters) deep, whereas the three sub-xeric communities occupied deeper soils. This soil depth distinction between xeric and sub-xeric communities corresponds roughly to Quarterman's (1973) Zone I (gravel glades) having soil depth less than about 2 inches ( 5 centimeters) and Zone II (grass glades) having soil depth greater than this threshold (Baskin and others, 2007b).

\footnotetext{
${ }^{7}$ Species name according to the Integrated Taxonomic Information System (2015).
}

Several distinct community types that exist as zonal components of limestone cedar glades are characterized by seasonally saturated or inundated conditions. Such communities meet many of the hydrologic and vegetation criteria required for delineation as wetlands (U.S. Army Corps of Engineers, 2010; Taylor and Estes, 2012), although wetland delineation based on hydric soils is made difficult by shallowness and seasonal drying of soils (Taylor and Estes, 2012). These communities include the Limestone Seep Glade/Kentucky Glade Seep, the Limestone Glade Streamside Meadow community, and the Interior Low Plateau Limestone Glade Ephemeral Pool (Nordman, 2004; Norton, 2010).

Characteristic species of the seasonally wet zones of limestone cedar glades include Isoetes butleri, Carex species (especially C. crawei), Eleocharis bifida, Nothoscordum bivalve, and Schoenolirion croceum as well as Nostoc cyanobacteria (Nordman, 2004; Baskin and others, 2007b).

Some debate and confusion has existed as to whetheror to what extent-limestone cedar glades are subject to succession. For example, Baskin and others (2007b) suggested conceptual models for plant succession while simultaneously asserting that cedar glades are characterized by "natural, long-persisting (edaphic climax) plant communities." Quarterman (1950b) delineated two primary types of succession in limestone cedar glades and later revised these through development of flow diagrams (Baskin and others, 2007b): succession beginning on bare rock (usually in very shallow depressions that retain some moisture after rains) and succession beginning in cracks and crevices in the bedrock. In the case of bare rock, early pioneers that establish the first thin soil layer are generally lichens, mosses, and cyanobacteria, and soil development is a process whereby isolated mats in depressions grow deeper and wider (usually showing concentric bands of pioneer species at the periphery and invader species in the center) until mats meet and merge (Baskin and others, 2007b). In the case of bedrock cracks, vegetation becomes established in fissures and deposits organic matter onto the surface of adjacent bedrock blocks, contributing to gradual accumulation of soil. Deep-rooted perennials established in fissures are able to tap into a source of soil moisture - in the form of decayed shale below the surface layers of limestone - that is unavailable to plants in shallow soil on intact bedrock (Quarterman, 1989). Quarterman (1950b) asserted that both succession types progress through seral stages (defined as gravel glade, grass glade, glade-shrub, shrub-redcedar, redcedar stand) toward redcedar-hardwood forest as the climax stage. Quarterman (1950b) acknowledged, however, that in both cases, succession is probably extremely slow, and that the "open glade stage" and "cedar stand in crevices with expanses of flat-topped blocks of limestone between trees" community types can be long-persisting subclimax stages for the two types, respectively. Thus, the competing hypotheses of how best to conceptualize the different observed communities within cedar glades (seral stages of succession versus climax communities along stress gradients) may be in part a question of time scales. At relatively 
short time scales, these community types probably represent sequences along a gradient, whereas at longer timescales that allow for the weathering of bedrock and the very slow accumulation of soil, more xeric community types might follow a succession pathway toward more mesic conditions.

Additionally, periodic disturbance - in the form of soil erosion from sheet flow during storm events, tree and shrub death from droughts, and fire - may result in changes in vegetation structure that are cyclical rather than directional (Quarterman, 1989; Quarterman and others, 1993). However, disturbance from fire is generally considered to be less important in maintaining southeastern limestone cedar glades than it is for "glades" (actually xeric limestone prairies, see chapter D) of the Ozark Plateaus and Midwestern States (Harper, 1926; Baskin and others, 2007a). Community composition in cedar glades may also be determined in part by geographical attributes. For a group of 40 cedar glades in Middle Tennessee, Cofer and others (2008) found that richness - of total species, native and exotic species, and endemic and nonendemic species - all increased significantly $(p<0.05)$ with increasing glade area and perimeter and decreased significantly with increasing isolation (distance between glade edge and the edge of the nearest glade).

\section{Differentiation from Related Ecosystems}

Limestone cedar glades differ in several ways from a closely related ecosystem type, xeric limestone prairies (see chapter D). Although both ecosystems develop on shallow, rocky soils over calcareous substrates, they differ in terms of topography, community composition, and factors maintaining ecosystem integrity (table $\mathrm{C}-1$ ). Limestone cedar glades generally are found on areas with level to moderate slopes, are dominated by summer annual grasses, and are considered to be an edaphic climax ecosystem, whereas xeric limestone prairies may be steeply sloped, are dominated by perennial grasses, and are maintained in part by disturbance (Baskin and Baskin, 2000; Lawless and others, 2006a, b; Baskin and others, 2007a). Additionally, mosses, lichens, cyanobacteria, and forbs are important in limestone cedar glades but much less so in xeric limestone prairies, and may be entirely absent in the latter (Baskin and others, 2007a). Despite these differences, even experts have had some difficulty differentiating between the two ecosystems (Baskin and Baskin, 2004). For example, Baskin and Baskin (1977) first described a community in Wilson County, Tennessee, as "an undescribed cedar glade" due to its dominance by Schizachyrium scoparium; however, they later stated that this site was actually a xeric limestone prairie (Baskin and Baskin, 2004).

Calcareous forest openings associated with stands of $J$. virginiana have been referred to as "cedar glades" in States including Oklahoma, Kansas, Missouri, Illinois, Indiana, Wisconsin, and Ohio (Baskin and Baskin, 1999; McClain and Ebinger, 2002; Mills, 2008). Although midwestern "cedar glades" are somewhat similar to southeastern cedar glades in terms of physiognomy and vegetation, Baskin and Baskin $(2000,2003)$ and Baskin and others (2007a) argued that they are fundamentally different ecosystems - more accurately categorized as barrens or as xeric limestone prairies - because they are maintained primarily by disturbance (fire and grazing) rather than by fundamental edaphic constraints and in the absence of disturbance will quickly succeed to redcedar and (or) hardwood forests. Forest openings referred to as "cedar glades" in the Ozark Plateaus are topographically different from true limestone cedar glades. Ozark "glades" commonly have slopes up to 50 percent, allowing them to be better drained than cedar glades of the Nashville Basin, which tend to be on level terrain (Baskin and others, 1968; Gates and others, 1982). "Cedar glades" in the Ozarks, like similar ecosystems in Midwest States, are primarily disturbance maintained and are not edaphic climax communities (Baskin and others, 1995). Similarly, "cedar glades" in West Virginia (Bartgis, 1993) have some physical and floristic similarity to limestone cedar glades of the Nashville Basin; however, the "glades" in West Virginia are more steeply sloping, tend to be well drained during the winter, support few winter annuals, and have a different suite of community dominants, leading Lawless and others (2006a) to categorize them as xeric limestone prairies.

"Cedar glades" have also been described as outcrop communities on diabase bedrock in the Piedmont region. Although these "cedar glades" have some floristic similarity to Nashville Basin limestone cedar glades, they also share some characteristic species with Piedmont granite outcrops (LeGrand, 1988). The Ketona dolomite glades of Bibb County, Alabama, also share some floristic elements with limestone cedar glades of the Nashville Basin; however, they are more steeply sloping and sustain a suite of endemic taxa not found in Nashville Basin glades (Allison and Stevens, 2001; Duncan and others, 2008). The Ketona dolomite glades were classified as xeric limestone prairies by Baskin and Baskin (2003) and are discussed in chapter D.

As a general rule, Quarterman (1989) and Baskin and Baskin (2004) reserve use of the term "glades" only for communities with less than 50 percent perennial grass cover, and they refer to communities with greater than 50 percent perennial grass cover as "barrens" or xeric limestone prairies. Quarterman (1989) similarly asserted that "barren" is a better term than "glade" for communities that are dominated by Schizachyrium scoparium, noting that this community type is generally found only on soil at least 8 inches (about 20 centimeters) deep. Early studies often used the term "cedar glades" to describe the outcrop areas and the accompanying redcedar forest; however, authors more recently have restricted use of the term to the outcrops only (Baskin and Baskin, 2004). 
Table C-1. Factors differentiating limestone cedar glades from xeric limestone prairies, adapted from Baskin and others (2007a).

$[<$, less than; cm, centimeter; m, meter $]$

\begin{tabular}{|c|c|c|c|}
\hline Factor & Limestone cedar glades & Xeric limestone prairies & References \\
\hline $\begin{array}{l}\text { Ecosystem } \\
\text { maintenance }\end{array}$ & $\begin{array}{l}\text { Edaphic climax communities, } \\
\text { disturbance is less important } \\
\text { to ecosystem maintenance }\end{array}$ & $\begin{array}{l}\text { Greater importance of distur- } \\
\text { bance (fire and grazing) }\end{array}$ & $\begin{array}{l}\text { Baskin and Baskin (2000), Lawless } \\
\text { and others (2006a), Baskin and } \\
\text { others (2007a) }\end{array}$ \\
\hline Topography & Level to moderate slopes & $\begin{array}{l}\text { Moderate to steep slopes, } \\
\text { typically with southern } \\
\text { to western aspect }\end{array}$ & $\begin{array}{l}\text { Erickson and others (1942), Bartgis } \\
\text { (1993), Quarterman and others } \\
\text { (1993), Baskin and Baskin (2000), } \\
\text { Laughlin and Uhl (2003), Baskin and } \\
\text { others (2007a) }\end{array}$ \\
\hline $\begin{array}{l}\text { Soil depth (depth } \\
\text { to bedrock) }\end{array}$ & $<30 \mathrm{~cm}$ & $<1 \mathrm{~m}$ & $\begin{array}{l}\text { Quarterman (1950a), Baskin and Baskin } \\
\text { (1977), Anderson and others (1999), } \\
\text { Baskin and Baskin (2003), Lawless } \\
\text { and others (2006a), Baskin and } \\
\text { others (2007a) }\end{array}$ \\
\hline $\begin{array}{l}\text { Geographic range } \\
\quad \text { (States) }\end{array}$ & $\begin{array}{l}\text { Tennessee, Kentucky, Virginia, } \\
\text { Alabama, and Georgia }\end{array}$ & $\begin{array}{l}\text { Arkansas, Missouri, Illinois, } \\
\text { Indiana, Ohio, Pennsylvania, } \\
\text { West Virginia, Virginia, } \\
\text { Kentucky, Tennessee, } \\
\text { Alabama, and Georgia }\end{array}$ & $\begin{array}{l}\text { Baskin and Baskin (1999), Baskin } \\
\text { and Baskin (2003), Lawless and } \\
\text { others (2006a) }\end{array}$ \\
\hline Center(s) of endemism & $\begin{array}{l}\text { Inner Nashville Basin of } \\
\text { Middle Tennessee }\end{array}$ & $\begin{array}{l}\text { Valley and Ridge of Alabama } \\
\text { (Ketona dolomite glades) and } \\
\text { Ozark Plateaus of Arkansas } \\
\text { and Missouri }\end{array}$ & $\begin{array}{l}\text { Baskin and Baskin (1999), Baskin } \\
\text { and Baskin (2003), Lawless and } \\
\text { others (2006a) }\end{array}$ \\
\hline Dominant vegetation & $\begin{array}{l}\text { C4 summer annual grasses } \\
\text { (for example, Sporobolus } \\
\text { vaginiflorus) and forbs }\end{array}$ & $\begin{array}{l}\mathrm{C} 4 \text { perennial grasses (for } \\
\text { example, Schizachyrium } \\
\text { scoparium) }\end{array}$ & $\begin{array}{l}\text { Quarterman (1989), Baskin and others } \\
\text { (1995), Baskin and Baskin (1999, } \\
\text { 2000), Lawless and others (2006a, b) }\end{array}$ \\
\hline
\end{tabular}

\section{Contributions to Regional Biodiversity}

Limestone cedar glades are ecosystems of conservation concern primarily because of their contributions to plant biodiversity (Noss, 2013). Some regionally rare plants in limestone cedar glades are endemics, whereas others represent disjunct populations of geographically widespread taxa from outside the southeastern United States. Limestone cedar glades also provide habitat to a number of animals of conservation concern.

\section{Endemic and Biogeographically Disjunct Taxa}

Limestone cedar glades support concentrations of plant taxa that are of conservation concern. Of all the plant taxa listed as rare in Tennessee by the Tennessee Division of Natural Heritage, 10 percent are found in limestone cedar glades (Vandevender, 2006). In Kentucky, 51 taxa that are considered rare or threatened at the State or Federal level are found within "forest openings" that include limestone cedar glades and related ecosystems such as xeric limestone 
prairies (Rhoades and others, 2004). The rare species associated with limestone cedar glade habitat include a number of endemic species, including so-called "strict endemics" that have only been found in limestone cedar glades as well as "near endemics" that are primarily restricted to cedar glades but have occasionally been found in related ecosystems such as xeric limestone prairies or outcrop communities on noncalcareous substrates. Some plant taxa are endemic only to cedar glades within certain geographic areas. Astragalus bibullatus, Echinacea tennesseensis, Leavenworthia stylosa, and Phacelia dubia var. interior are restricted to the Nashville Basin; Delphinium alabamicum, Leavenworthia alabamica, Leavenworthia crassa, and Lesquerella lyrata are restricted to northern Alabama; and Leavenworthia exigua var. laciniata is restricted to the Outer Bluegrass region of northern Kentucky (Baskin and others, 1995; Baskin and Baskin, 2003). Many of the cedar glade endemics and near-endemics are regionally or globally rare and are of conservation concern. For example, E. tennesseensis, A. bibullatus, and Dalea foliosa have been federally listed as endangered or threatened species (Norton, 2010; Sutter and others, 2011), although E. tennesseensis was delisted in 2011 (Bowen, 2011). Several characteristic glade plants are shown in figure $\mathrm{C}-5$. Of these, A. bibullatus is considered a strict endemic to limestone cedar glades, while Dalea gattingeri, Leavenworthia exigua, and Pediomelum subacaule are considered near-endemics because they also are present in xeric limestone prairies.

Limestone cedar glade endemics and near-endemics are primarily herbaceous dicots, therophytes, and hemicryptophytes, and all have $\mathrm{a}_{3}$ photosynthetic pathway (Baskin and Baskin, 1985, 1999). Generally, cedar glade interiors are areas of high abiotic stress and low competition relative to the surrounding forest, and cedar glade endemics tend to be specially adapted to stress conditions and poor competitors with mesic species (Quarterman, 1950b; Norton, 2010). Cedar glade endemics tend to be obligate heliophytes, unable to compete in even moderately shaded environments (Baskin and others, 1968; Baskin and Baskin, 1988; Quarterman, 1989). Most glade endemics have no special morphological adaptations for seed dispersal, and their mode of dispersal is gravity; however, some seeds of endemics are dispersed by wind and (or) water (Baskin and Baskin, 1989; Cofer and others, 2008).

Although considerable research has been done on the autecology and growth requirements of cedar glade endemics, the full suite of factors controlling their distribution and local abundance is still not fully understood. Some evidence suggests that certain glade species grow preferentially in specific microhabitats. Somers and others (1986) found that Talinum calcaricum, Leavenworthia stylosa, and L. exigua grew in soils that were substantially shallower than average cedar glade soils and that Viola egglestonii, Pediomelum subacaule, and $L$. torulosa grew preferentially toward the edges of glades near the margin of the surrounding redcedar forest. These results are indicative of niche partitioning among cedar glade endemics, based in part on soil depth and shading gradients. The spatial distribution of some glade endemics is also apparently regulated in part by allelopathy, as several glade species contain chemicals that inhibit seed germination of other taxa (Quarterman, 1973; Quarterman, 1989). For example, germination of Minuartia patula, a nonendemic, is inhibited by extracts from Dalea gattingeri (Baskin and Baskin, 1989; Quarterman and others, 1993).

Attempts to identify the proximal cause(s) of endemism for cedar glade species have been only partially successful. Although research indicates that all of the endemics are shade-intolerant and compete poorly with mesic species, these factors alone do not appear sufficient to fully explain their endemism, and no other unique biological or physiological traits have been identified that fully explain why endemics are restricted to cedar glade habitat (Baskin and Baskin, 1988, 1989). Edaphic factors (soil chemical and physical properties) and genetic factors were explored by Baskin and Baskin (1988), but neither adequately accounted for the observed endemism of limestone cedar glades. Baskin and others (1997) compared Echinacea tennesseensis (a cedar glade endemic) and Solidago shortii (which grows in glade-like communities) to their geographically widespread congeners $-E$. angustifolia and S. altissima, respectively - and ruled out a number of physiological, ecological, cytological, genetic, and life-history factors in explaining the narrow geographic restriction of the endemics, leading them to conclude that historical factors, namely the presence or absence of past opportunities for range expansion, likely played some role in fostering endemism for these glade species; see also Walck and others (2001).

One set of traits shared by many cedar glade endemics involves special adaptations to the particular stress regime of their ecosystem (high levels of sunlight, thin soil, and widely fluctuating soil temperatures and hydrologic conditions). Types of adaptations common to cedar glade endemics and to other characteristic glade taxa include tolerance of high irradiance and drought (Baskin and Baskin, 1974; Quarterman and others, 1993) as well as tolerance of seasonal inundation and seasonally saturated soil conditions (Taylor and Estes, 2012). Quarterman (1950a) pointed to the timing of life cycles, particularly the timing of dormancy, as being a critically important adaptive strategy to survive seasonally extreme hydrologic conditions. A number of taxa complete their life cycles during the wet season and survive the dry season as seeds, corms, or bulbs. Adaptive advantages of the winter-annual life cycle include not only the ability to survive summer drought conditions through dormancy but also the ability to persist as seedlings during the winter when frost heaving of the thin soil is excessive (Quarterman and others, 1993). A special adaptation common to the winterannual glade endemics is self-compatibility (the ability to self-pollinate and set seed), which is necessary for life-cycle completion because few pollinators are active during the winter and early spring flowering period (Quarterman and others, 1993; Noss, 2013). Some other glade taxa are dormant during the period of saturation and complete their life cycle in the summer and fall. Some glade taxa possess specialized adaptations to cope with seasonal saturation and anaerobic 

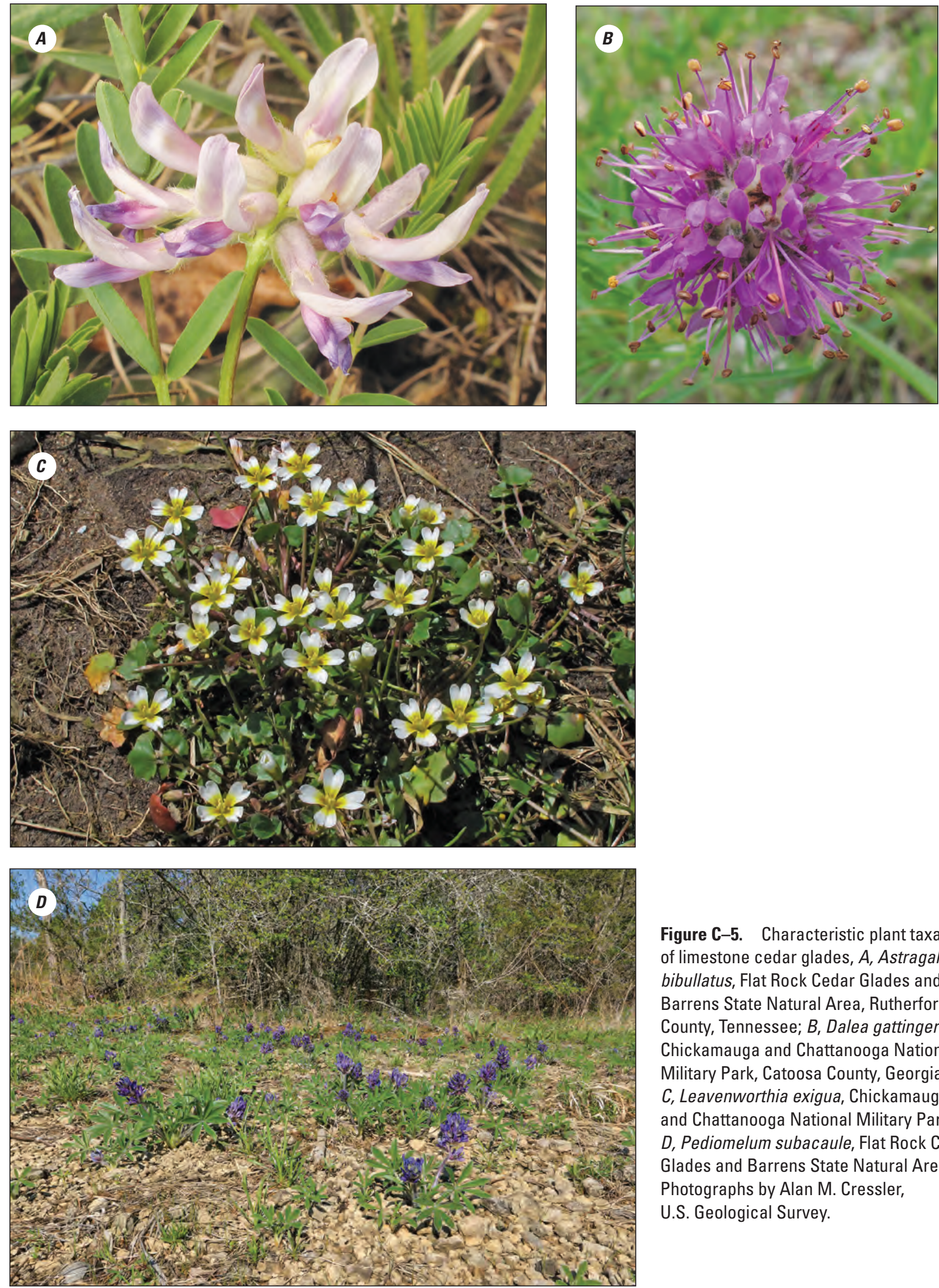

Figure C-5. Characteristic plant taxa of limestone cedar glades, A, Astragalus bibullatus, Flat Rock Cedar Glades and Barrens State Natural Area, Rutherford County, Tennessee; $B$, Dalea gattingeri, Chickamauga and Chattanooga National Military Park, Catoosa County, Georgia; C, Leavenworthia exigua, Chickamauga and Chattanooga National Military Park; $D$, Pediomelum subacaule, Flat Rock Cedar Glades and Barrens State Natural Area. Photographs by Alan M. Cressler, U.S. Geological Survey. 
conditions. Leavenworthia uniflora, for example, does not accumulate ethanol in roots the way most plants do when in saturated soil conditions, suggesting that it has metabolic adaptations to protect it from cytotoxic effects of root zone hypoxia (Baskin and Baskin, 1989; Norton, 2010).

Another characteristic shared by several cedar glade taxa is biogeographic disjunction, meaning that occurrences within limestone cedar glades are geographically remote from primary ranges in other regions or represent substantial range expansions; see Braun (1955) and Brown and others (1996). Harper (1926) observed that a number of plant taxa in limestone cedar glades were disjunct to home ranges in the Great Plains. Since then, several generations of researchers have noted glade species disjunctions to the Ozark Plateaus and to the Great Plains (Bridges and Orzell, 1986; Quarterman and others, 1993; Norton, 2010). Glade-associated taxa with population centers in physiographic regions where limestone cedar glades are not present include Dalea foliosa, which is in glaciated northern regions of the Midwest, and Oxalis priceae ssp. priceae, whose range includes the Coastal Plain of Alabama (Baskin and Baskin, 2003). Additionally, cedar glades support a number of eastern species of western genera, for example the narrow endemic Astragalus bibullatus, which belongs to a genus mostly found in arid western regions (Noss, 2013). Other primarily western genera with species found in cedar glades of the southeastern United States include Echinacea, Onosmodium, Pediomelum, Penstemon, and Phemeranthus (Noss, 2013).

\section{Animal Taxa of Conservation Concern}

In comparison to studies of vascular plants, relatively few investigations in limestone cedar glades have focused on animals or microbes. Martin and Sharp (1983) compiled species lists of soil protozoa and found that species richness was not well correlated with available soil moisture or $\mathrm{pH}$. Martin and Sharp (1983) also noted a conspicuous absence of the ciliate genus Colpoda, which is usually abundant in soil. Meyer (1937) published detailed records of invertebrate species (annelids, mollusks, and arthropods) collected in a Middle Tennessee cedar glade, but found no substantial difference in species composition among different habitat types when open glades were compared to redcedar forest and to shrub-dominated areas. Hill (2010; 2012), however, focusing exclusively on grasshoppers, found discernible differences in species composition between open glade habitat, redcedar forest, and adjacent xeric limestone prairie. This survey of grasshoppers in cedar glades and associated ecosystems also resulted in documentation of four species for the first time in Tennessee, as well as the description of a new species, Melanoplus ingrami, which is suspected to be a cedar glade endemic. Although aquatic invertebrate fauna were observed by Taylor and Estes (2012) in seasonally inundated zones of cedar glades, no formal documentation or study of aquatic fauna has yet been published.
Working in another Middle Tennessee cedar glade, Jordan and others (1968) reported a community composition of amphibians and reptiles different from that normally found in the surrounding region - most notably the absence of species requiring moist or aquatic conditions - and suggested that the dry conditions of cedar glades provided a favorable habitat for lizards and lizard-consuming snakes. Some amphibian taxasuch as Anaxyrus fowleri (Fowler's toad) - were more abundant in the open, rocky glade areas relative to the surrounding forest, whereas other species - such as Anaxyrus americanus (the American toad) - showed the opposite trend. Based on 20 years of herpetofaunal survey data from seven sites in Middle Tennessee containing cedar glade habitat, Niemiller and others (2011) concluded that although no amphibian or reptile species are endemic to cedar glades, several species are more frequently encountered in cedar glade habitat than in surrounding mesic forest and that cedar glades and associated woodlands provide habitat to several species of conservation concern. Schultz (1930) found that many of the bird species present in a Middle Tennessee cedar glade were characteristic of early successional fields and other open or edge habitat, with a corresponding paucity of bird species requiring deciduous forest conditions. Although no bird species have been identified as relying solely on limestone cedar glades for habitat, cedar glades do support a number of avian species of conservation concern, including Thryomanes bewickii (Bewick's wren), Setophaga discolor (prairie warbler), and Vermivora cyanoptera (blue-winged warbler) (Ford and others, 2000).

\section{Conservation Considerations}

A number of researchers familiar with the biodiversity contributions of limestone cedar glades have stressed the importance of their conservation (Quarterman and others, 1993; Noss and others, 1995; Baskin and others, 2007b). These arguments commonly have involved descriptions of current and historical threats to limestone cedar glades, assessment of existing conservation approaches, and identification of scientific knowledge gaps.

\section{Threats to Ecosystem Integrity}

According to estimates by the Tennessee Department of Environment and Conservation, about 50 percent of total limestone cedar glade area has been lost and 90 percent of ecologically intact limestone cedar glades have been lost from the Nashville Basin of Middle Tennessee, rendering limestone cedar glades an "endangered ecosystem" (Noss and others, 1995). Population growth and suburban sprawl are commonly cited as major threats to limestone cedar glades forming on land that is not already publicly owned or otherwise protected from development (Nordman, 2004; Baskin and others, 
2007b). Comparison of Freeman's (1933) hand-drawn map of his study site to current aerial photography indicates that the cedar glades upon which he based his well-cited publication have likely been destroyed by human development. In Middle Tennessee, the construction of the Percy Priest Reservoir flooded more than 202,000 acres (about 82,000 hectares) in the "heart of glade country" and almost certainly resulted in the destruction of many cedar glades and associated redcedar forests, as well as encouraged private development along the lakeshore (Quarterman and others, 1993).

Harper (1926) observed limestone cedar glades in Middle Tennessee that had been severely damaged by lumbering and grazing. Quarterman (1950b) mentioned grazing, the cutting of Juniperus virginiana trees for fenceposts, and the scraping of glades to harvest gravel as primary threats. Niemiller and others (2011) described degradation of cedar glades and related ecosystems resulting from off-road recreational vehicles, rock gathering, and suburban sprawl. Dumping of garbage in cedar glades has also been a problem, arising from a popular misperception of cedar glades as "wastelands" (Quarterman and others, 1993). Field reconnaissance in Tennessee and Kentucky by Norton (2010) indicated that most cedar glades on private land showed evidence of severe anthropogenic destruction - grazing, recreational vehicle use, garbage dumping, and scraping for gravel — and these glades on private land supported relatively few rare taxa.

One of the indirect effects of anthropogenic disturbance is often the introduction of exotic species. Quarterman and others (1993) suggested that hikers and off-road vehicles can introduce weeds such as Ambrosia artemisiifolia and Cirsium discolor, which can out-compete glade flora and degrade the structure of glade communities. Sutter and others (2011) reported a marked increase of woody species, particularly the exotic Ligustrum sinense, in calcareous glades between 1993 and 2008 and attributed these changes primarily to fire suppression and the introduction of invasive species; however, they did not differentiate between limestone cedar glades (edaphic climax communities) and xeric limestone prairies (already known to be maintained by disturbance), and thus the relevance of their findings to only cedar glades is unclear. Comparing $L$. sinense, which is listed as a "severe threat" to native plant communities by the Tennessee Exotic Pest Plant Council (2009), to Forestiera ligustrina, which is a native shrub with a similar growth habit, Morris and others (2002) found that $L$. sinense had spatial and temporal advantages in capturing light as well as the production of a large quantity of fruits, both attributes that might account for its ability to rapidly colonize and displace native species.

In recent studies, the percentage of total glade flora found to be exotic species has generally been between 10 and 20 percent: 18.8 percent in a cluster of cedar glades in Middle Tennessee (Cofer and others, 2008); 13.4 percent for a group of glades in northern Alabama (Baskin and others, 1995); and 17.6 percent for glade flora across the southeastern
United States as a whole (Baskin and Baskin, 2003). By contrast, forest canopies growing on glade-forming soils in the Inner Nashville Basin contain few if any exotic species (Adams and others, 2012).

Because most glade endemics are poor competitors and fill a niche based on high abiotic stress, the greatest threat from exotic invasive species would presumably be the arrival of exotics that are competitive and have adaptations for drought or anaerobic tolerance (Norton, 2010). In the southeastern United States, the exotic species considered to be of greatest potential threat to limestone cedar glades are Lonicera japonica, L. maackii, and Ligustrum sinense (Nordman, 2004; Cofer and others, 2008; Norton, 2010). Herbaceous exotic species may present a greater threat than woody exotics because of their ability to invade areas beyond crevices and glade perimeters (Cofer and others, 2008; Norton, 2010). Examples of herbaceous exotics with potential to invade limestone cedar glades include Carduus nutans, Daucus carota, Lespedeza cuneata, Leucanthemum vulgare, and Melilotus officinalis (Cofer and others, 2008; Norton, 2010), all of which are listed as current or potential threats to native plant communities in Tennessee by the Tennessee Exotic Pest Plant Council (2009).

\section{Conservation Strategies}

A number of State and Federal conservation programs are underway in an attempt to preserve limestone cedar glades. A few examples of State, Federal, and private preserves containing protected limestone cedar glades are Chickamauga and Chattahoochee National Military Park, Cedar Glades State Forest and Natural Area, Cedars of Lebanon State Park, Long Hunter State Park, Mount View Cedar Glade, the Percy Priest Lake area, Flat Rock Cedar Glade Preserve, and Stones River National Battlefield (Quarterman and others, 1993). In some cedar glades on protected and publicly owned land, native plant restoration programs are underway (Vandevender, 2006), including attempts to establish new and self-sustaining populations of rare cedar glade endemics in suitable glade habitat where those endemics do not currently grow (Nordman, 2004; Albrecht and McCue, 2010). Quarterman and others (1993) pointed out that the sparse or patchy distribution of some glade endemic species complicates the process of selecting individual glades or glade clusters for conservation. Species inventories at the level of individual glades may be necessary to ensure that conservation strategies encompass the full range of gene pools for endemic species. Also, conservation of small glades may be equally important to that of larger glades because small glades may serve as corridors between larger glades and thus help facilitate dispersal and establishment of glade endemics, especially those whose seeds are dispersed by gravity (Mann and others, 1999; Cofer and others, 2008). 


\section{Knowledge Gaps}

Although several generations of researchers have intensively studied limestone cedar glades and their endemic species, many important questions remain unanswered. For example, few researchers have conducted systematic hydrologic investigations of limestone cedar glades, and currently the nonprecipitation sources of water inputs to these ecosystems as well as their connectivity to subterranean karst features is largely unknown (Norton, 2010). Although the presence of aquatic fauna has been noted (Taylor and Estes, 2012), systematic documentation of aquatic fauna or their trophic relationships has yet to be conducted. Some possible anthropogenic effects on cedar glades have not been scientifically examined, including nitrogen deposition due to air pollution (Jeffrey Walck, Middle Tennessee State University, written commun., 2014) and localized changes to precipitation regimes due to heat-island effects from nearby urban areas (Shepherd and others, 2002). The degree to which limestone cedar glades are vulnerable to woody encroachment has not been conclusively established. Also, compared to studies of the vegetation of cedar glade interiors and associated redcedar stands, less attention has been paid to the surrounding mixed hardwood forests that occupy the same glade-forming soils (Adams and others, 2012).

\section{Possible Ecological Effects from Climate Change}

Although cases of relatively obvious anthropogenic destruction have been noted repeatedly by cedar glade researchers, very little attention has been paid to the potential effects of climate change. As discussed in chapter D, MolanoFlores and Bell (2012) developed a population variability analysis for Dalea foliosa based on climate-change scenarios. This analysis, however, was for a single plant species (present in limestone cedar glades but also in related prairie contexts in the northern Midwest) and was based on populations in noncedar-glade habitat in Illinois, rendering its applicability to limestone cedar glade ecosystems unclear. For example, Molano-Flores and Bell (2012) identified changes in seasonal timing of snowmelt as important to Illinois populations of
D. foliosa. Such effects on populations in limestone cedar glades farther south would likely be different because of regional climatic differences.

Regional changes in the timing, amount, and (or) variability of precipitation have not yet been systematically investigated as a possible threat to limestone cedar glades. Such changes might be expected to affect glade-associated taxa with life histories that are closely tied to historical patterns of seasonal soil desiccation and saturation. Furthermore, regional temperature changes might affect such taxa by altering evapotranspiration dynamics. For example, Norton (2010) suggested that increased temperatures during the spring might lead to seasonally saturated zones within cedar glades drying out earlier in the year, making it more difficult for hydrophytic taxa within these zones to complete their life cycles. This hypothesis was not empirically tested and does not account for interactive effects of temperature changes with possible seasonal increases in regional precipitation. Increased summer temperatures or changes in precipitation timing and magnitude might also alter seasonal patterns of xeric soil conditions in cedar glades, with ecological effects that could be difficult to predict. For example, increased duration or intensity of summer drought conditions might be expected to help exclude mesic competitors from cedar glade habitat; however, such changes might also overwhelm the adaptive capacities of glade endemics to survive xeric conditions.

Predicting ecological effects of climate change in limestone cedar glades is also complicated by spatial variability in soil moisture dynamics and by the coexistence of plant taxa with differing adaptive strategies for surviving extreme hydrologic conditions. In addition to-or interacting withclimate-change-induced alteration of abiotic stress regimes, alterations to biological interactions could represent a possible threat to cedar glade ecological integrity. For example, in other ecosystems, changes to the seasonal timing of the availability of pollinators has resulted in phenological asynchrony, a phenomenon whereby differential shifts in seasonal timing of life cycles can disrupt interspecific interactions (Walther and others, 2002; Walther, 2010). An assessment of the potential for such disruptions to occur in limestone cedar glade communities would require more detailed understanding of the interspecific interactions governing key constituents of cedar glade ecosystems and of their tolerance to seasonal shifts. 


\section{References}

Adams, D., Walck, J., Howard, R., and Milberg, P., 2012, Forest composition and structure on glade-forming limestones in Middle Tennessee: Castanea, v. 77, no. 4, p. 335-347.

Albrecht, M., and McCue, K., 2010, Changes in demographic processes over long time scales reveal the challenge of restoring an endangered plant: Restoration Ecology, v. 18, no. S2, p. 235-243.

Allison, J., and Stevens, T., 2001, Vascular flora of Ketona dolomite outcrops in Bibb County, Alabama: Castanea, v. 66 , no. 1, p. 154-205.

Anderson, R., Fralish, J., and Baskin, J., 1999, Savannas, barrens, and rock outcrop plant communities of North America: Cambridge University Press, New York.

Bartgis, R., 1993, The limestone glades and barrens of West Virginia: Castanea, v. 58, no. 2, p. 69-89.

Baskin, C., and Baskin, J., 1974, Responses of Astragalus tennesseensis to drought: Oecologia, v. 17, no. 1, p. 11-16.

Baskin, J., and Baskin, C., 1977, An undescribed cedar glade community in Middle Tennessee: Castanea, v. 42, no. 2, p. 140-145.

Baskin, J., and Baskin, C., 1981, Photosynthetic pathways indicated by leaf anatomy in 14 summer annuals of cedar glades: Photosynthetica, v. 15, p. 205-209.

Baskin, J., and Baskin, C., 1985, Photosynthetic pathway in 14 southeastern cedar glade endemics, as revealed by leaf anatomy: American Midland Naturalist, v. 114, no. 1, p. 205-208.

Baskin, J., and Baskin, C., 1988, Endemism in rock outcrop plant communities of unglaciated eastern United StatesAn evaluation of the roles of the edaphic, genetic and light factors: Journal of Biogeography, v. 15, no. 5, p. 829-840.

Baskin, J., and Baskin, C., 1989, Cedar glade endemics in Tennessee, and a review of their autecology: Journal of the Tennessee Academy of Science, v. 64, no. 3, p. 63-74.

Baskin, J., and Baskin, C., 1999, Cedar glades of the southeastern United States, in Anderson, R., Fralish, J., and Baskin, J., eds., Savannas, barrens, and rock outcrop plant communities of North America: New York, Cambridge University Press, p. 206-219.
Baskin, J., and Baskin, C., 2000, Vegetation of limestone and dolomite glades in the Ozarks and Midwest regions of the United States: Annals of the Missouri Botanical Garden, v. 87, no. 2, p. 286-294.

Baskin, J., and Baskin, C., 2003, The vascular flora of cedar glades of the southeastern United States and its phytogeographical relationships: Journal of the Torrey Botanical Society, v. 130, no. 2, p. 101-118.

Baskin, J., and Baskin, C., 2004, History of the use of "cedar glades" and other descriptive terms for vegetation on rocky limestone soils in the Central Basin of Tennessee: The Botanical Review, v. 70, no. 4, p. 403-424.

Baskin, J., Baskin, C., and Lawless, P., 2007a, Calcareous rock outcrop vegetation of eastern North America (exclusive of the Nashville Basin), with particular reference to use of the term "cedar glades": The Botanical Review, v. 73, no. 4, p. 303-325.

Baskin, J., Baskin, C., and Quarterman, E., 2007b, Flow diagrams for plant succession in the Middle Tennessee cedar glades: Journal of the Botanical Research Institute of Texas, v. 1, no. 2, p. 1131-1140.

Baskin, J., Quarterman, E., and Caudle, C., 1968, Preliminary check-list of the herbaceous vascular plants of cedar glades: Journal of the Tennessee Academy of Science, v. 43, no. 3, p. $65-71$.

Baskin, J., Snyder, K., Walck, J., and Baskin, C., 1997, The comparative autecology of endemic, globally-rare, and geographically-widespread, common plant species - Three case studies: The Southwestern Naturalist, v. 42, no. 4, p. 384-399.

Baskin, J., Webb, D., and Baskin, C., 1995, A floristic plant ecology study of the limestone glades of northern Alabama: Bulletin of the Torrey Botanical Club, v. 122, no. 3, p. 226-242.

Bowen, B., 2011, Natural areas protection at its best; protecting the Tennessee purple coneflower (Echinacea tennesseensis): Natural Areas Journal, v. 31, no. 4, p. 326-330.

Braun, E., 1955, The phytogeography of unglaciated eastern United States and its interpretation: The Botanical Review, v. 21 , no. 6 , p. 297-375.

Bridges, E., and Orzell, S., 1986, Distribution patterns of the non-endemic flora of Middle Tennessee limestone glades: ASB Bulletin, v. 33, p. 155-166. 
Brown, J., Stevens, G., and Kaufman, D., 1996, The geographic range-Size, shape, boundaries, and internal structure: Annual Review of Ecology and Systematics, v. 27 , no. 1996 , p. 597-623.

Cartwright, J., 2014, Soil ecology of a rock outcrop ecosystem-Abiotic stresses, soil respiration, and microbial community profiles in limestone cedar glades: Nashville, Tenn., Tennessee State University, Ph.D. Dissertation.

Cartwright, J., and Hui, D., 2014, Soil respiration patterns and controls in limestone cedar glades: Plant and Soil, v. 389, no. 1-2, p. 157-169.

Cofer, M., Walck, J., and Hidayati, S., 2008, Species richness and exotic species invasion in Middle Tennessee cedar glades in relation to abiotic and biotic factors: The Journal of the Torrey Botanical Society, v. 135, no. 4, p. 540-553.

Dubois, J., 1993, Biological dinitrogen fixation in two cedar glade communities of Middle Tennessee: Journal of the Tennessee Academy of Science, v. 68, no. 4, p. 101-105.

Duncan, R., Anderson, C., Sellers, H., and Robbins, E., 2008, The effect of fire reintroduction on endemic and rare plants of a southeastern glade ecosystem: Restoration Ecology, v. 16 , no. 1, p. $39-49$.

Eickmeier, W., 1986, The distribution of photosynthetic pathways among cedar glade plants: ASB Bulletin, v. 33, p. 200-205.

Erickson, R., Brenner, L., and Wraight, J., 1942, Dolomitic glades of east-central Missouri: Annals of the Missouri Botanical Garden, v. 29, no. 2, p. 89-101.

Estill, J., and Cruzan, M., 2001, Phytogeography of rare plant species endemic to the southeastern United States: Castanea, v. 66, no. 1, p. 3-23.

Fenneman, N., and Johnson, D., 1946, Physical divisions of the United States: U.S. Geological Survey map prepared in cooperation with the Physiographic Commission, scale $1: 7,000,000$.

Ford, R., Carr, S., Hunter, C., York, J., and Reodel, M., 2000, Partners in flight bird conservation plan for the Interior Low Plateaus (Physiographic Area 14): Washington, D.C., American Bird Conservancy.

Freeman, C., 1933, Ecology of the cedar glade vegetation near Nashville Tennessee: Journal of the Tennessee Academy of Science, v. 8, p. 143-228.

Gates, J., Settergren, C., Henderson, G., and Krstansky, J., 1982, Hydrology of a south-central Missouri cedar glade: Water and Soil Management, v. 1, p. 36-41.
Harper, R., 1926, The cedar glades of Middle Tennessee: Ecology, v. 7, no. 1, p. 48-54.

Hill, J., 2010, A new species of Melanoplus (Orthoptera: Acrididae: Melanoplinae) from the cedar glades of Tennessee, USA: Journal of Orthoptera Research, v. 19, no. 2, p. 341-345.

Hill, J., 2012, Habitat associations of grasshoppers (Orthoptera: Acrididae) in the heterogeneous cedar glade landscape of the Central Basin of Tennessee: Journal of Orthoptera Research, v. 21, no. 2, p. 227-233.

Integrated Taxonomic Information System, 2015, The Integrated Taxonomic Information System, accessed October 5, 2015, at http://www.itis.gov.

Jordan, O., Garton, J., and Ellis, R., 1968, The amphibians and reptiles of a Middle Tennessee cedar glade: Journal of the Tennessee Academy of Science, v. 43, no. 3, p. 72-78.

Laughlin, D., and Uhl, C., 2003, The xeric limestone prairies of Pennsylvania: Castanea, v. 68, no. 4, p. 300-316.

Lawless, P., Baskin, J., and Baskin, C., 2004, The floristic ecology of xeric limestone prairies in Kentucky, and a comparison to limestone cedar glades and deep-soil barrens: Sida, v. 21, no. 70, p. 1055-1079.

Lawless, P., Baskin, J., and Baskin, C., 2006a, Xeric limestone prairies of eastern United States-Review and synthesis: The Botanical Review, v. 72, no. 3, p. 235-272.

Lawless, P., Baskin, J., and Baskin, C., 2006b, Scaledependent classification of xeric limestone prairiesAnnual or perennial grasslands?: Annals of the Missouri Botanical Garden, v. 93, no. 3, p. 455-464.

LeGrand, H., 1988, Cedar glades on diabase outcropsA newly described community type: Castanea, v. 53, no. 2, p. $168-172$.

Mahr, W., and Mathis, P., 1981, Foliose and fruticose lichens of the cedar glades in Stones River National Battlefield Park (Rutherford County, Tennessee): Journal of the Tennessee Academy of Science, v. 56, no. 2, p. 66-67.

Mann, L., King, A., Dale, V., Hargrove, W., WashingtonAllen, R., Pounds, L., and Ashwood, T., 1999, The role of soil classification in geographic information system modeling of habitat pattern-Threatened calcareous ecosystems: Ecosystems, v. 2, p. 524-538.

Martin, E., and Sharp, R., 1983, Soil protozoa from a cedar glade in Rutherford County, Tennessee: Journal of the Tennessee Academy of Science, v. 58, no. 3 and 4, p. 31-36. 
McClain, W., and Ebinger, J., 2002, A comparison of the vegetation of three limestone glades in Calhoun County, Illinois: Southeastern Naturalist, v. 1, no. 2, p. 179-188.

Meyer, A., 1937, An ecological study of cedar glade invertebrates near Nashville, Tennessee: Ecological Monographs, v. 7 , no. 3 , p. $403-443$.

Mills, J., 2008, Fifty years of change in Wisconsin cedar glades: The American Midland Naturalist, v. 159, no. 1, p. 214.

Molano-Flores, B., and Bell, T., 2012, Projected population dynamics for a federally endangered plant under different climate change emission scenarios: Biological Conservation, v. 145 , no. 1 , p. 130-138.

Morris, L., Walck, J., and Hidayati, S., 2002, Reproduction of the invasive Ligustrum sinense and native Forestiera ligustrina (Oleaceae) - Implications for the invasion and persistence of a nonnative shrub: International Journal of Plant Sciences, v. 163, no. 6, p. 1001-1010.

Nelson, P., Fitzgerald, J., Larson, K., McCoy, R., Schotz, A., Taft, J., Witsell, T., and Yahn, B., 2013, Central hardwoods joint venture glade conservation assessment for the Interior Highlands and Interior Low Plateaus of the Central Hardwoods region: Central Hardwoods Joint Venture.

Niemiller, M., Reynolds, R., Glorioso, B., Spiess, J., and Miller, B., 2011, Herpetofauna of the cedar glades and associated habitats of the Inner Central Basin of Middle Tennessee: Herpetological Conservation and Biology, v. 6 , no. 1, p. $135-149$.

Nordman, C., 2004, Vascular plant community classification for Stones River National Battlefield: Durham, N.C., NatureServe.

Norton, K., 2010, A floristic ecology study of seasonally wet limestone cedar glades of Tennessee and Kentucky: Clarksville, Tenn., Austin Peay State University, Masters Thesis.

Noss, R., 2013, Forgotten grasslands of the south: Washington, D.C., Island Press.

Noss, R., LaRoe, E., and Scott, J., 1995, Endangered ecosystems of the United States-A preliminary assessment of loss and degradation: Washington, D.C., U.S. Department of the Interior.

Quarterman, E., 1950a, Ecology of cedar glades. I. Distribution of glade flora in Tennessee: Bulletin of the Torrey Botanical Club, v. 77, no. 1, p. 1-9.

Quarterman, E., 1950b, Major plant communities of Tennessee cedar glades: Ecology, v. 31, no. 2, p. 234-254.
Quarterman, E., 1973, Allelopathy in cedar glade plant communities: Journal of the Tennessee Academy of Science, v. 48, no. 4, p. 147-150.

Quarterman, E., 1989, Structure and dynamics of the limestone cedar glade communities in Tennessee: Journal of the Tennessee Academy of Science, v. 64, no. 3, p. 155-158.

Quarterman, E., Burbanck, M., and Shure, D., 1993, Rock outcrop communities - Limestone, sandstone, and granite, in Martin, W., Boyce, S., and Echternacht, A., eds., Biodiversity of the southeastern United States-Upland terrestrial communities: New York, John Wiley and Sons, Inc., p. 35-86.

Rhoades, C., Miller, S., and Shea, M., 2004, Soil properties and soil nitrogen dynamics of prairie-like forest openings and surrounding forests in Kentucky's Knobs Region: The American Midland Naturalist, v. 152, no. 1, p. 1-11.

Rollins, S., 1997, Calcareous glade communities in the Central Basin of Tennessee-The effects of scale on community classification: Chapel Hill, N.C., University of North Carolina, Masters Thesis.

Schultz, H., 1930, Birds of the cedar glades of Middle Tennessee: Nashville, Tenn., George Peabody College for Teachers, Thesis.

Shepherd, J., Pierce, H., and Negri, A., 2002, Rainfall modification by major urban areas - Observations from spaceborne rain radar on the TRMM satellite: Journal of Applied Meteorology, v. 41, p. 689-702.

Somers, P., Smith, L., Hamel, P., and Bridges, E., 1986, Preliminary analyses of plant communities and seasonal changes in cedar glades of Middle Tennessee: ASB Bulletin, v. 33 , p. $178-192$.

Sutter, R., Govus, T., Smyth, R., Nordman, C., Pyne, M., and Hogan, T., 2011, Monitoring change in a central U.S. calcareous glade - Resampling transects established in 1993: Natural Areas Journal, v. 31, no. 2, p. 163-172.

Taylor, K., and Estes, D., 2012, The floristic and community ecology of seasonally wet limestone glade seeps of Tennessee and Kentucky: Journal of the Botanical Research Institute of Texas, v. 6, no. 2, p. 711-724.

Tennessee Exotic Pest Plant Council, 2009, TN-EPPC invasive exotic pest plants in Tennessee, accessed on November 18, 2015, at http://www.tneppc.org/invasive_ plants?sort_by=latin_name\#invasive_plants_table. 
U.S. Army Corps of Engineers, 2010, Interim regional supplement to the Corps of Engineers wetland delineation manual-Eastern Mountains and Piedmont Region, in Wakeley, J., Lichvar, R., Noble, C., and Berkowitz, J., eds., ERDC/EL TR10-9: Vicksburg, Miss., Army Engineer Research and Development Center.

U.S. Department of Agriculture, 2015, Ecological subregions-Sections and subsections for the conterminous United States: Vector digital data, adapted from Fenneman and Johnson (1946) and ECOMAP (2007). Washington, D.C., U.S. Department of Agriculture, U.S. Forest Service.

U.S. Geological Survey, National Gap Analysis Program, 2011, Land cover data portal, accessed December 2015 at http://gapanalysis.usgs.gov/gaplandcover/data/download/.

Vandevender, J., 2006, Native plant restoration at Stones River National Battlefield, in People, Places and Parks: Proceedings of the 2005 George Wright Society Conference on Parks, Protected Areas and Cultural Sites: The George Wright Society, Inc., p. 146-148.
Walck, J., Baskin, J., and Baskin, C., 2001, Why is Solidago shortii narrowly endemic and S. altissima geographically widespread? A comprehensive comparative study of biological traits: Journal of Biogeography, v. 28, no. 10, p. 1221-1237.

Walther, G., 2010, Community and ecosystem responses to recent climate change: Philosophical Transactions of the Royal Society, B, v. 365, p. 2019-2024.

Walther, G., Post, E., Convey, P., Menzel, A., Paremesan, C., Beebee, T., Fromentin, J., Hoegh-Guldberg, O., and Bairlein, F., 2002, Ecological responses to recent climate change: Nature, v. 416, p. 389-395. 


\section{Chapter D. Xeric Limestone Prairies}

\section{Introduction}

Xeric limestone prairies (fig. D-1) are open, moderately to steeply sloped nonforested areas, are dominated by $\mathrm{C}_{4}$ perennial grasses, and are present on relatively shallow, rocky soils derived from calcareous substrates (limestone and dolomite) that may include limited outcrops of bedrock (Laughlin and Uhl, 2003; Lawless and others, 2006a). Xeric limestone prairies commonly exist within a larger mosaic including woodland and shrub-dominated ecosystems - referred to as a "glade-woodland complex" or a "savanna-like ecosystem"and can grade into limestone cedar glades (Cipollini and others, 2005; Comer and others, 2011).

\section{Geographic Range and Differentiation from Related Ecosystems}

Xeric limestone prairies are present in 6 physiographic provinces (the Ozark Plateaus, Central Lowland, Interior Low Plateaus, Appalachian Plateaus, Valley and Ridge, and Coastal Plain) in 12 States: Arkansas, Missouri, Illinois, Indiana, Ohio, Pennsylvania, West Virginia, Virginia, Kentucky, Tennessee, Alabama, and Georgia (fig. D-2; Lawless and others, 2006a). Within these States, xeric limestone prairies generally are present in unglaciated regions (Baskin and Baskin, 1999), such as in the extreme southern regions of Ohio and Indiana and in southern and western Illinois (Lawless and others, 2006a).

Figure D-1. Grand Prairie, Coosa Valley Prairies, Floyd County,

Georgia. Photograph by Alan M. Cressler, U.S. Geological Survey. 
Because of their relatively widespread geographic distribution, xeric limestone prairies develop in subtropical and temperate climatic regions and under a variety of precipitation regimes, with yearly precipitation amounts generally increasing from north to south and from west to east across their geographic range (Lawless and others, 2006a).

Xeric limestone prairies have been referred to by a number of regional and colloquial names including barrens, alkaline barrens, prairies, dolomite prairies, prairie barrens, savannas, forest openings, grasslands, limestone glades, and cedar glades. This diversity of terminology has created considerable confusion, has slowed the recognition of fundamental similarities between related sites that are widely distributed geographically, and conversely has led to the conflation of ecosystems that are fundamentally distinct (Heikens and Robertson, 1994; Ludwig, 1999; Guyette and others, 2003; Cipollini and others, 2005; Lawless and others, 2006a). A considerable number of xeric limestone prairies have probably been mislabeled as other ecosystem types. For example, Copenheaver and others (2005) referred to a study site as "a typical southern Appalachian bald" despite the site having an elevation of less than 1,600 feet (about 500 meters) and having bedrock geology and vegetation composition that suggest it was actually a xeric limestone prairie. DeSelm and Murdock

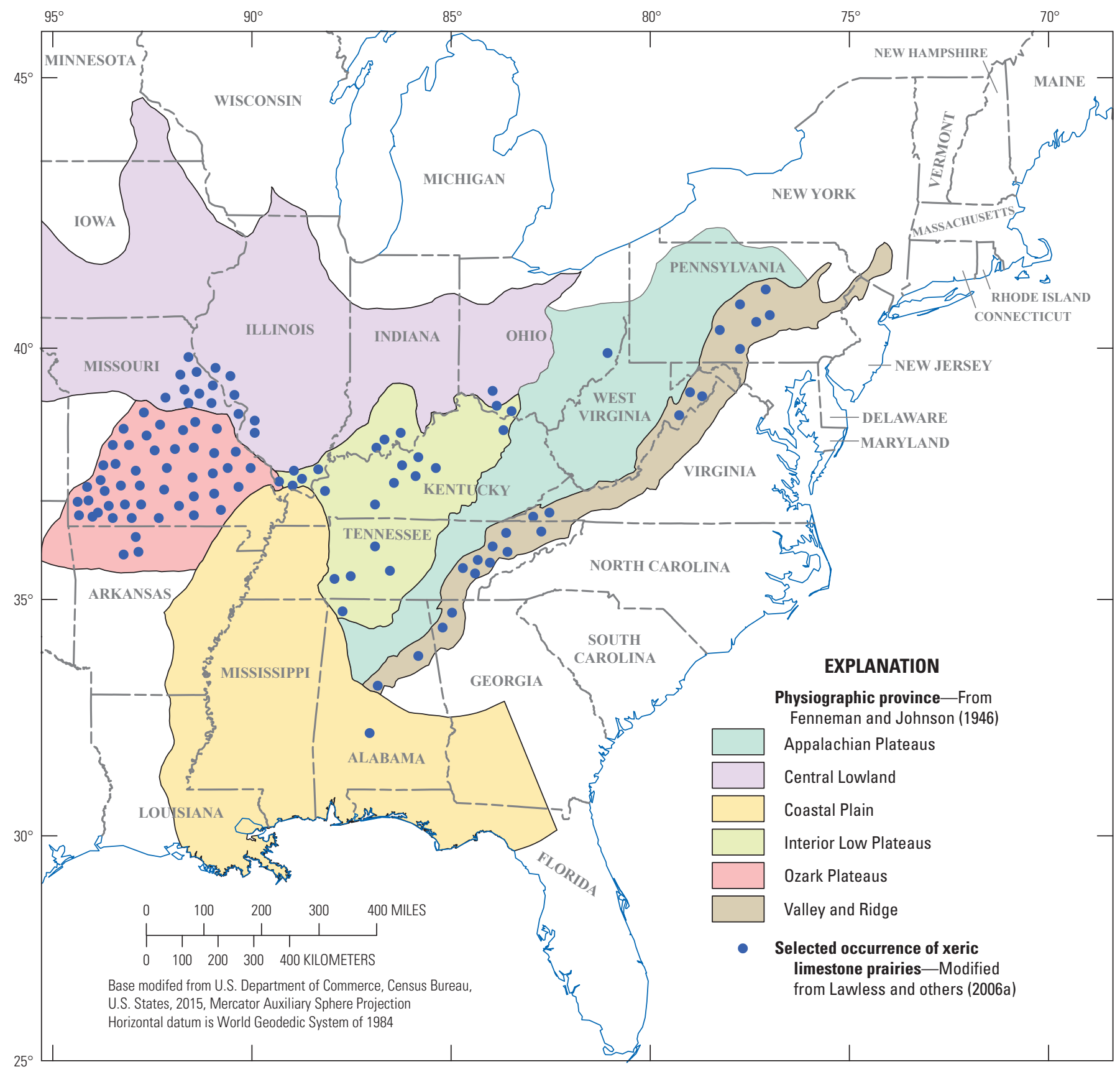

Figure D-2. General geographic distribution of xeric limestone prairies. 
(1993) noted that in Kentucky and Tennessee, grass-dominated communities of all types are generally referred to as "barrens." Xeric limestone prairies have been referred to as "barrens" in Virginia (Ludwig, 1999), West Virginia (Bartgis, 1993), Illinois (Heikens and Robertson, 1995), and Indiana (Homoya, 1994). However, xeric limestone prairies are easily differentiated from arable, deep-soil barrens, such as those in the "Big Barrens" region of southern and central Kentucky and northern Tennessee, by their endemism and thin soils (Baskin and others, 1999; Laughlin and Uhl, 2003).

Use of the terms "glades" and "cedar glades" in reference to xeric limestone prairies - for example Bartgis (1993), Kimmel and Probasco (1980), and Mills (2008)—-has resulted in confusion in the literature related to the identification of both ecosystems. Recently, explicit attention to the problem of terminology has helped clarify which systems are true glades and which are actually xeric limestone prairies (Baskin and Baskin, 2004; Baskin and others, 2007a). Forest openings in the Ozark region especially have commonly been referred to as "glades" (Erickson and others, 1942; Heikens, 1999; Nelson and others, 2013), even though limestone glades - as defined by Baskin and Baskin (1999) — are not present west of the Mississippi River and Ozark "glades" are generally classified as xeric limestone prairies by those researchers who explicitly differentiate xeric limestone prairies from limestone cedar glades; see, for example, Lawless and others (2006a). This differentiation rests on a number of topographic, floristic, and ecological distinctions between the two ecosystem types (see table $\mathrm{C}-1$ in chapter $\mathrm{C}$ ). In some cases, however, limestone cedar glades can be found adjacent to or as microhabitats within xeric limestone prairies, as areas of relatively shallow soil depth and microsite dominance of $\mathrm{C}_{4}$ summer annual grasses such as Sporobolus vaginiflorus var. vaginiflorus (Baskin and Baskin, 2000).

The dolomite "glades" of Bibb County, Alabama (fig. D-3), which are present over the Ketona Dolomite, may represent a special sub-class of xeric limestone prairies (Baskin and Baskin, 2003). Referred to here as the Ketona dolomite glades, these forest openings correspond to the Alabama Ketona Glade and Woodland ecological system according to the International Terrestrial Ecological Systems Classification (ITESC). When these communities were first described, Allison (1994) and Allison and Stevens (2001) asserted that they were distinct from the limestone cedar glades of the Inner Central Basin of Middle Tennessee in a number of ways, including topography (the Ketona dolomite glades develop on steep slopes) and vegetation (dominance by Schizachyrium scoparium and relative scarcity of S. vaginiflorus var. vaginiflorus), despite the presence in the Ketona dolomite glades of two species otherwise believed to

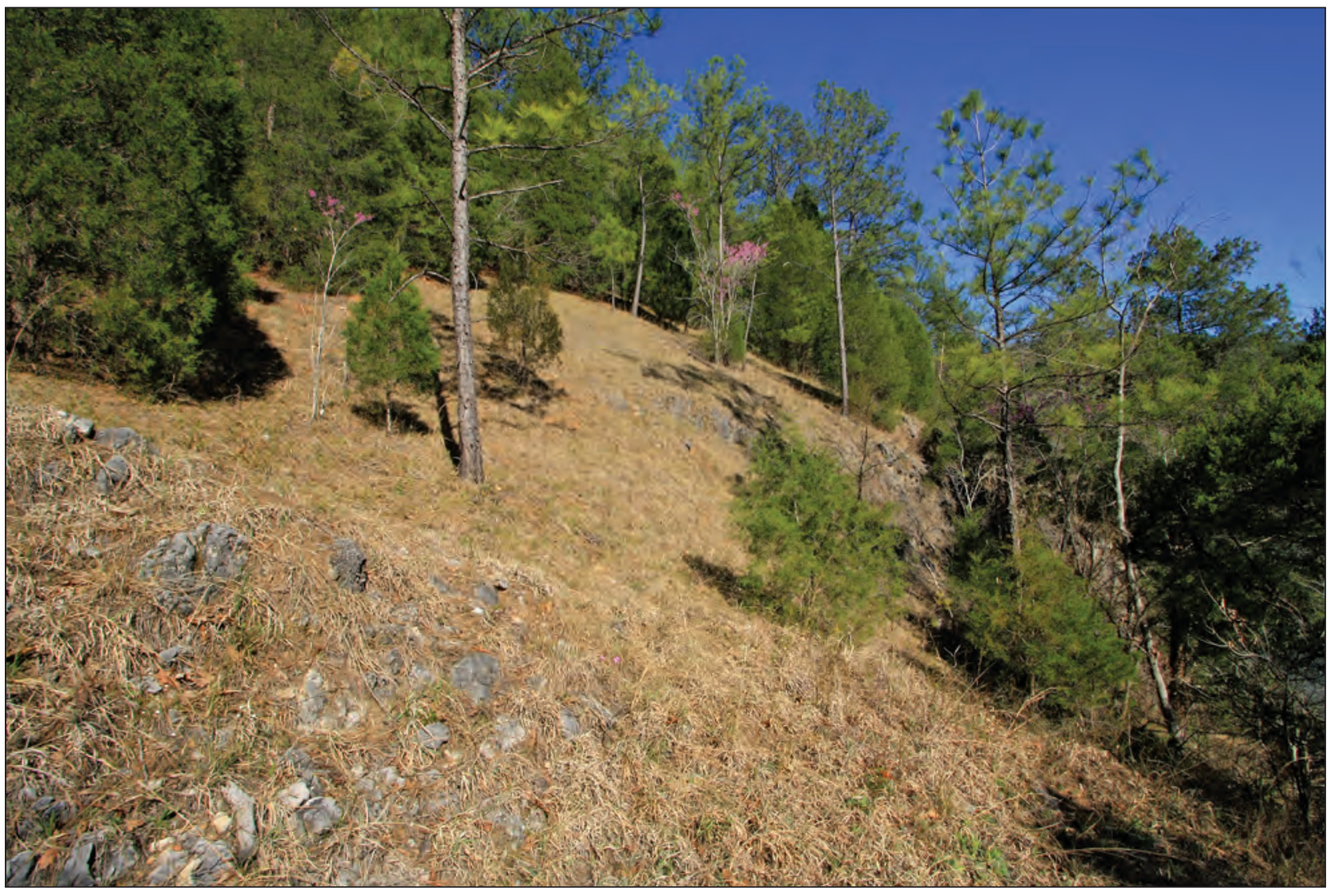

Figure D-3. Ketona dolomite glade, Kathy Stiles Freeland Bibb County Glades Preserve, Bibb County, Alabama. Photograph by Alan M. Cressler, U.S. Geological Survey. 
be endemics to limestone cedar glades: Leavenworthia exigua var. lutea and Pediomelum subacaule. In addition, the Ketona dolomite glades contain several endemic species of their own (not present in limestone cedar glades or in any other outcrop community) and do not contain most of the limestone cedar glade endemics, leading Allison and Stevens (2001) and Baskin and Baskin (2003) to conclude that the Ketona dolomite glades are distinct from limestone cedar glades. Baskin and Baskin (2003) argued that the topographic and vegetation characteristics of the Ketona dolomite glades are consistent with a classification as xeric limestone prairies. Allison and Stevens (2001) acknowledged that the Ketona dolomite glades show greatest similarity to the xeric limestone prairie category; however, they pointed to three lines of evidence to argue that a new category should be created specifically to accommodate the Ketona dolomite glades: (1) they contain multiple endemics not found in (other) xeric limestone prairies, (2) they support two species of Leavenworthia, and (3) they develop over dolomite rather than limestone. Both arguments have merit, and certainly if the Ketona dolomite glades are categorized as xeric limestone prairies, then attention should be paid to their special characteristics and their suite of endemics that are not present on other xeric limestone prairies.

\section{Physical Geography}

Throughout their geographic range, xeric limestone prairies share characteristics related to bedrock geology, soils, and topography. The calcareous bedrock substrates of xeric limestone prairies are of a wide range of ages, from Cambrian through Mississippian, and possibly Pennsylvanian and even Eocene (Lawless and others, 2006a). Xeric limestone prairies generally develop on rocky soils (alfisols, ultisols, mollisols, inceptisols, and vertisols) that are less than approximately 3 feet (about 1 meter) thick and circumneutral to slightly alkaline (Homoya, 1994; Lawless and others, 2006a; Nelson and others, 2013). Xeric limestone prairies generally have southern to western aspects (Heikens and Robertson, 1995; Laughlin and Uhl, 2003; Nelson and others, 2013), although a few in the Ozark Plateaus are present on north-facing slopes (Theo Witsell, Arkansas Natural Heritage Commission, written commun., 2014). Rhoades and others $(2004,2005)$ asserted that xeric limestone prairies in the Knobs region of northern and central Kentucky (see fig. 1 in Rhoades and others, 2004) are confined to a narrow band of elevation, corresponding to a sedimentary layer of relatively soft calcareous shale between outcrops of harder dolomite. Edaphic conditions in xeric limestone prairies are controlled in part by the interaction of soil texture with topographic position. Soils tend to be fine-textured clay and silty clay loams. This texture, combined with the slope of xeric limestone prairies, which ranges from moderate to steep, makes these soils prone to erosion at rates that exceed soil genesis (Ware, 2002; Lawless and others, 2004, 2006a).

\section{Stress and Disturbance Regimes}

The factors most often cited as contributing to the origin and maintenance of xeric limestone prairies include geo-edaphic conditions (calcareous substrates, shallow soils influenced by erosion, limitation of certain important nutrients), topography (moderate to steep slopes with southern to western aspects), hydrologic conditions, and disturbance regimes based on fire and grazing (Homoya, 1994; Ludwig, 1999; Baskin and Baskin, 2000; Laughlin and Uhl, 2003; Lawless and others, 2006a). Although the relative importance of these factors has been a subject of debate (Cipollini and others, 2005; Lawless and others, 2006a), in many cases, xeric limestone prairies likely have been maintained by complex, site-specific interactions of several different factors.

Edaphic stress in xeric limestone prairies typically involves seasonally extreme hydrologic conditions (Kucera and Martin, 1957). Seasonally xeric soil conditions are produced by the interaction of soil and landscape properties, including soil shallowness, abundance of rock fragments causing excessive drainage, relatively high insolation, and typically southern to western aspects (Laughlin and Uhl, 2003; Ware, 2010). The steep slope of some xeric limestone prairies also limits infiltration of precipitation because of fast runoff (Homoya, 1994). These factors suggest that seasonal water limitation and susceptibility to drought may help retard woody encroachment and thus maintain herbaceous habitat (Heikens and Robertson, 1995).

On the other hand, many xeric limestone prairies experience seasonal saturation and frost-heaving of the thin soils from late fall to early spring, which are factors that may help exclude species vulnerable to winter rotting (Erickson and others, 1942; Hall, 1955; Kucera and Martin, 1957; Heikens and Robertson, 1994; Nelson and others, 2013). In some xeric limestone prairies, thinly bedded and relatively porous limestone and dolomite strata are underlain by impermeable strata, causing percolation to be impeded and redirected laterally, such that areas of rock outcrop may have abundant seepage during the winter and spring (Erickson and others, 1942; Ludwig, 1999; Allison and Stevens, 2001; Ware, 2002). In many ways, these seasonal patterns of extreme hydrology mirror those occurring in limestone cedar glades (Quarterman, 1950; Taylor and Estes, 2012). In contrast to limestone cedar glades, however, xeric limestone prairie communities contain relatively few winter-annual species - an adaptation to xeric summer conditions in which plants are dormant during the driest part of the year-suggesting that warm-season water stress may be less severe in xeric limestone prairies than in limestone cedar glades (Lawless and others, 2004).

A number of soil properties display steep gradients from xeric limestone prairie interiors to adjacent forests, suggesting that edaphic conditions may help determine the geographic location and extent of xeric limestone prairies (Kucera and Martin, 1957; Allison and Stevens, 2001; Belden and others, 2003; Rhoades and others, 2004, 2005). For example, bulk density, silt content, $\mathrm{pH}$, and calcium availability were found 
to be elevated in xeric limestone prairie soils relative to surrounding forest soils (Rhoades and others, 2005). In one study, several soil taxonomic components, including presence of a mollic epipedon and soil thickness of less than about 20 inches (roughly 50 centimeters), could be used to predict the spatial distribution of habitat for threatened taxa from calcareous grasslands (Mann and others, 1999). A growing body of research suggests that xeric limestone prairie soils are nutrient-poor relative to surrounding forests (Homoya, 1994) and relative to other grass-dominated ecosystems in North America (Rhoades and others, 2004). In particular, a number of researchers have noted low potassium availability in xeric limestone prairie soils (Ludwig, 1999; Allison and Stevens, 2001; Rhoades and others, 2004; Trammell and others, 2004).

Disturbance regimes are also important in xeric limestone prairies. In particular, many investigations of successional dynamics have emphasized the importance of fire (Heikens and Robertson, 1994; Batek and others, 1999; Heikens, 1999; Baskin and Baskin, 2000; Guyette and others, 2003). Important components of fire regimes include seasonality, frequency, and intensity. High-intensity fires can result in loss of nutrients from ecosystems by a variety of mechanisms, including direct oxidation and volatilization, erosion, convection of ash, and nutrient leaching; however, small and low-intensity fires from prescribed burns have been shown to have minimal effect on leaching (Trammell and others, 2004). In addition to the direct effects on woody vegetation, fire may also slow the pace of woody encroachment indirectly by exacerbating water stress in soils, both by increasing radiant heating and by removing moisture-retaining litter (Homoya, 1994).

Historical fire regimes that regulated succession dynamics in xeric limestone prairies were probably a combination of natural and anthropogenic fires; however, the relative importance of the two fire types has been debated (Sauer, 1950; Batek and others, 1999; Laughlin, 2004; Noss, 2013). A number of researchers, including Guyette and others (2003), have emphasized the importance of anthropogenic fire and argued that natural fires were rare in the regions where xeric limestone prairies are present because lightning strikes - though frequent-were usually accompanied by heavy precipitation. By contrast, Foti and Glenn (1991) indicated a high prevalence of present-day lightning-set fires in the summer and early autumn in the Ouachita Mountains. Analysis of fire scars has consistently shown high fire incidence during the period of Native American occupation and much less frequent fire during the past 100 years (Jenkins and others, 1997; Guyette and others, 2003; Laughlin, 2004). Batek and others (1999) and Heikens (1999) concluded that grassland-shrub mosaics in the Ozarks, which include xeric limestone prairies, were maintained to a large extent by anthropogenic fire. On the other hand, the high degree of endemism present in some xeric limestone prairies argues strongly against origin or maintenance solely or primarily by anthropogenic disturbance because it is highly unlikely that so many endemics could have evolved during the relatively short timespan of human occupation (Noss, 2013). Also, historical accounts suggest that xeric limestone prairies were the last remaining types of forest openings in the Ozark Plateaus Physiographic Province by the mid-1800s, after many of the native barrens and savannas had been degraded or succeeded to forest (Heikens, 1999). A similar history has been proposed in southern Indiana (Guyette and others, 2003). If this history is true, it suggests that other factors beyond fire disturbance, possibly including topographic and edaphic factors, also play a role in maintaining xeric limestone prairies (Erickson and others, 1942; Hall, 1955; Homoya, 1994). The topographic and edaphic similarity of xeric limestone prairies contributes to this line of reasoning: if fire was the sole factor needed to create and maintain xeric limestone prairies, then they should be found with similar frequency on level ground, on north-facing slopes, and in sites with nutrient-rich soil (Homoya, 1994).

Grazing is another important aspect of the historical disturbance regime for many xeric limestone prairies. Prior to the establishment of agriculture in North America, grasslands were grazed by large herbivores such as elk and bison and later by domesticated herbivores such as sheep, cows, and horses (Lawless and others, 2006a). Thus, grazing is an ancient phenomenon that has been altered in recent times by human intervention. Some Native Americans were known to pasture cattle before European settlement, and they could have used some xeric limestone prairies for this purpose (Webb and others, 1997). Many xeric limestone prairies also show evidence of more recent pasturing. In the Knobs region of Kentucky, Rhoades and others (2004) noted fence remnants near the edges of some xeric limestone prairies. In northwestern Alabama, Webb and others (1997) stated that most forest openings not suitable for tillage-including xeric limestone prairies because of their thin soils - were used for grazing until the 1940s. Describing barrens and "glades" (probably xeric limestone prairies based on the reported dominance of $\mathrm{C}_{4}$ perennial grasses), Bartgis (1993) noted that most of these areas had been heavily used for sheep pasture. In eastern Missouri, Erickson and others (1942) noted that most "glades" had been occupied by cattle and, to a lesser extent, hogs. As with fire regimes, the ecological effects of grazing depend on frequency and intensity. For example, light to moderate grazing typically produces mosaics of shrub and grassland that support higher levels of species diversity than do grasslands that result from high-intensity grazing (DeSelm and Murdock, 1993).

Historically, xeric limestone prairies likely have been maintained by complex interactions of disturbance regimes with edaphic and hydrologic conditions. These interactions may have involved a number of feedback loops. For example, in addition to the direct effects of drought in slowing or reversing woody encroachment, drought is also intrinsically linked to fire regimes in the absence of fire suppression (DeSelm and Murdock, 1993; Quarterman and others, 1993). In turn, fires can exacerbate existing dry soil conditions (Homoya, 1994) and nutrient limitation (Trammell and others, 2004). Nutrient limitation and water stress may act synergistically as a stress regime experienced by plants 
because nutrient absorption is impeded by xeric conditions (Heikens and Robertson, 1995). Prairies created by these processes would presumably become attractive grazing sites to native herbivores and to pastoralists, and grazing in turn has the potential to alter plant community composition, vegetation dynamics, and soil physical properties (DeSelm and Murdock, 1993; Nelson and others, 2013). Depending on topographic setting, removal of woody vegetation by fire and (or) grazing can make soils more prone to erosion (Trammell and others, 2004; Lawless and others, 2006a), and soil depletion from erosion might retard woody encroachment by contributing to water and nutrient stress. Additionally, disturbance to adjacent forests or woodlands may expand existing prairie sites and change vegetation dynamics (Harper, 1920; Laughlin, 2004). Thus, topography, hydrology, edaphic conditions, and disturbance events have probably interacted in highly complex ways to produce and maintain xeric limestone prairies, and the nature of these interactions has undoubtedly varied from one site to another.

\section{Community Types and Vegetation Dynamics}

Xeric limestone prairies are typically characterized by a relatively stable matrix of graminoids and a highly variable - and less dominant - component of forbs (Lawless and others, 2006a). Figure D-4 shows such a graminoid and forb community. The characteristic dominant species is Schizachyrium scoparium, which has been suggested as one criterion for the differentiation of xeric limestone prairies from limestone cedar glades (Quarterman, 1989; Baskin and Baskin, 2000; Lawless and others, 2006a, b). Other $\mathrm{C}_{4}$ perennial grasses common in xeric limestone prairies include Bouteloua curtipendula, Andropogon gerardii, Sorghastrum nutans, and Sporobolus clandestinus (Kucera and Martin, 1957; Lawless and others, 2006a). Although less dominant, $\mathrm{C}_{3}$ perennial forbs (including Silphium terebinthinaceum, Monarda fistulosa, and some Cyperaceae

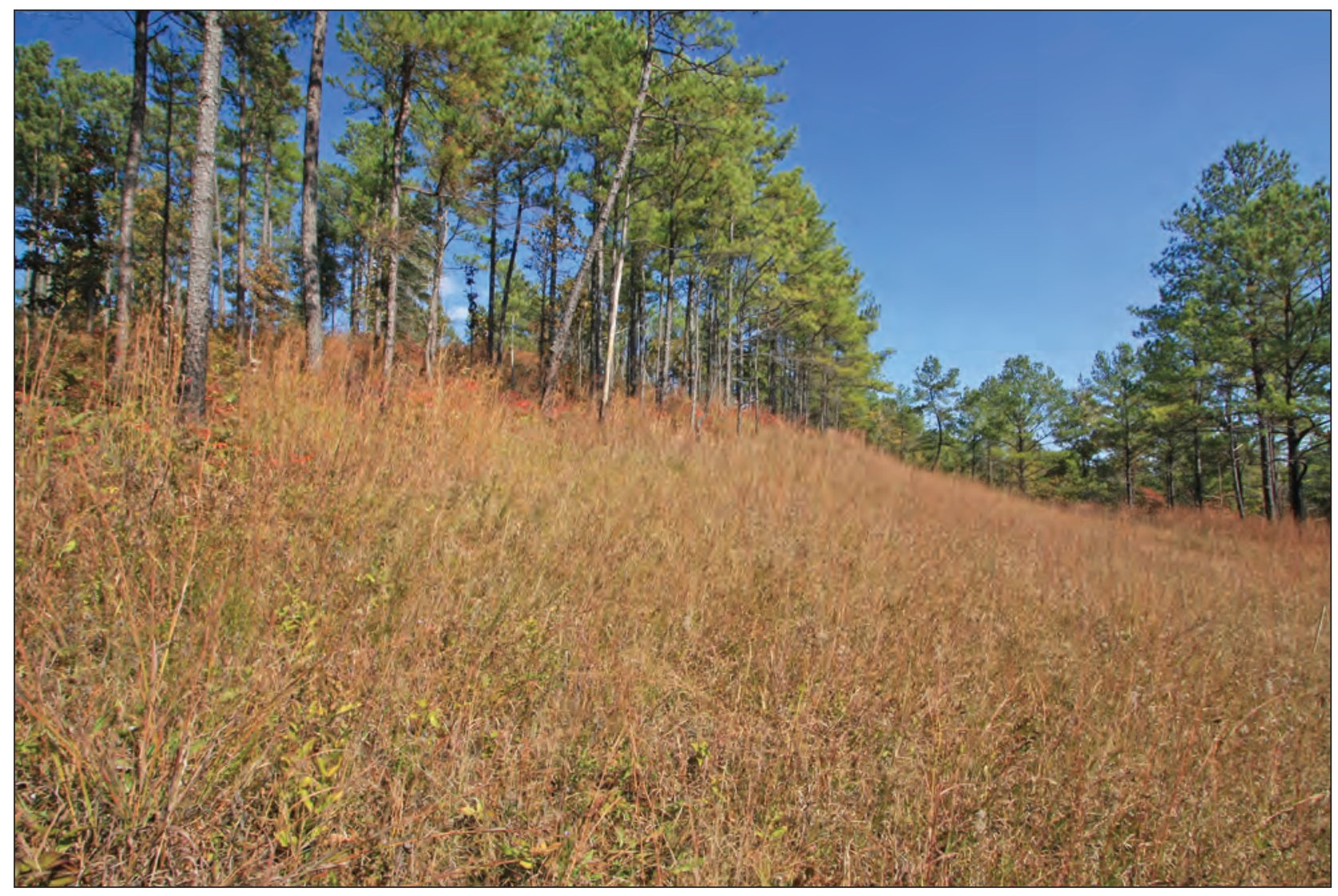

Figure D-4. Dry Prairie, Coosa Valley Prairies, Floyd County, Georgia. Photograph by Alan M. Cressler, U.S. Geological Survey. 
taxa) and $\mathrm{C}_{4}$ summer annual grasses (such as Sporobolus vaginiflorus and $S$. neglectus) may be locally abundant at some sites (Kucera and Martin, 1957; Baskin and Baskin, 2000; Lawless and others, 2006a). Typically, xeric limestone prairies support assemblages containing geographically restricted taxa and geographically widespread disturbance-adapted taxa (Ware, 2010). Multiple microhabitats within xeric limestone prairies generally support characteristic plant assemblages, and community zonation may be strongly controlled by soil depth gradients (Ware, 2002). For example, $\mathrm{C}_{4}$ summer annual grasses are often restricted to areas with the shallowest soil (Baskin and Baskin, 2000; Rhoades and others, 2004; Lawless and others, 2006b), leading Baskin and Baskin (2000) to assert that "cedar glades of the type described for the southeastern United States... occur in microhabitats within xeric limestone prairies."

Xeric limestone prairies as an ecosystem category, as defined by Lawless and others (2004), do not correspond neatly to classification according to the ITESC and the U.S. National Vegetation Classification (USNVC) and include a number of component associations of the ecological systems Ozark Prairie and Woodland, Eastern and Western Highland Rim Prairie and Barrens, Pennyroyal Karst Plain Prairie and Barrens, Central Interior Highlands Calcareous Glade and Barrens, and Southern Ridge and Valley Calcareous Glade and Woodland (NatureServe, 2015). Differing terminologies and attitudes toward ecosystem change have existed among researchers studying these prairies. Some have described increased cover of woody species as "encroachment," "invasion," and "degradation" (Laughlin, 2004; Sutter and others, 2011), whereas others described it simply as succession (Baskin and others, 2007b). Regardless, a number of different methods (such as long-term monitoring based on field visits, comparison of modern and historical floristic lists, and methods using aerial photography and remote sensing) have documented the shrinking size of xeric limestone prairies across their geographic range, with a strong association between the increase of woody species and declines in species diversity and in populations of endemic species (Kimmel and Probasco, 1980; Annala and Kapustka, 1983; Lowell and Astroth, 1989; Heikens and Robertson, 1995; Laughlin and Uhl, 2003; Mills, 2008; Young and others, 2009; Sutter and others, 2011).

Some studies have also explicitly linked woody encroachment with changes in disturbance regimes. In the Ozarks, for example, fire intervals increased from 4 years in the $1870 \mathrm{~s}$ to $22-24$ years by the end of the 20th century, with the areal extent of xeric limestone prairies decreasing by roughly 60 percent over the same time period (Heikens, 1999; Comer and others, 2011). Other investigations have found perimeters of xeric limestone prairies to be relatively stable over the course of decades. Rhoades and others (2004) attributed the relative lack of woody encroachment onto forest openings in the Knobs region of Kentucky over a 75-year interval (evidenced by aerial photography) to edaphic differences between these openings and the surrounding forest, but also noted evidence of past grazing. Also using aerial photography, Ludwig (1999) found limited encroachment onto 12 xeric limestone prairies in extreme southwestern Virginia over a 33 -year interval and attributed this stability to a combination of drought stress and fire.

The relative importance of edaphic constraints versus disturbance to ecosystem maintenance has implications for the speed and geographic extent of woody encroachment near the edges of xeric limestone prairies (Heikens and Robertson, 1995; Trammell and others, 2004). In the absence of disturbance, succession in xeric limestone prairies may not be uniform given the coexistence of multiple heterogeneous microhabitats. Some areas within xeric limestone prairies may be edaphically constrained more than others and may succeed more slowly due to edaphic or hydrologic constraints (DeSelm and others, 1969; Trammell and others, 2004). At a regional scale, climatic differences may control succession rates as well. For example, succession in Ozark Plateaus xeric limestone prairies might be more constrained by dry summer conditions compared to Valley and Ridge prairies that experience greater precipitation during the growing season (Lawless and others, 2006a; Sutter and others, 2011).

In the Ozark Plateaus, the primary woody species involved in encroachment onto xeric limestone prairies include Juniperus virginiana, Quercus marilandica, Carya texana, and Acer saccharum (Heikens, 1999). In southern Ohio, the primary woody species are $J$. virginiana, Pinus virginiana, Cercis canadensis, and various Quercus species (Annala and Kapustka, 1983). In their flow diagrams of succession pathways for limestone cedar glades, Baskin and others (2007b) conceptualized xeric limestone prairies as disturbancemediated alternatives to the seral stage of redcedar (J. virginiana) forests: the prior seral stage (shrub-redcedar) would be followed by xeric limestone prairie if the area was subjected to disturbance (grazing or fire) but in the absence of disturbance would be followed by redcedar forest, which would then be followed by redcedar/hardwood forest and would eventually become mixed hardwood forest. The presence of woody exotic invasive species such as Ligustrum sinense (Morris and others, 2002; Sutter and others, 2011) complicates the succession pathways described by Baskin and others (2007b) because in the absence of disturbance, xeric limestone prairies may become dominated as much by $L$. sinense as by $J$. virginiana. 


\section{Contributions to Regional Biodiversity}

Throughout their range, xeric limestone prairies provide habitat for globally rare taxa (see table 3-3 in appendix 3) (Webb and others, 1997; Laughlin and Uhl, 2003; Rhoades and others, 2005). A number of regionally distinct and globally rare plant associations also are present within these ecological systems, including Ozark Limestone Glades, Ozark Dolomite Glades, Ozark Annual Grass Glade, Ozark Ashe's Juniper Glade Woodland, Moulton and Tennessee Valley Limestone Hill Barrens, Southern Limestone Glade Margin Shrubland, and Outer Bluegrass Dolomite Glade (Nelson and others, 2013). Several federally listed plant taxa are found in xeric limestone prairies, including Dalea foliosa, which is federally listed as endangered and has been documented in xeric limestone prairies associated with limestone cedar glades, and Lesquerella filiformis, which is present in the Ozark Highlands and is listed as threatened (Thompson and others, 2006; Young and others, 2009; Nelson and others, 2013). The Ketona dolomite glades of Bibb County, Alabama, are exceptional as habitat for rare species. Spigelia gentianoides var. alabamensis is federally listed as endangered and is present only in the Ketona dolomite glades; Marshallia mohrii is federally listed as threatened and also is present in other disturbancemaintained herbaceous habitats (Allison and Stevens, 2001). A total of more than 60 plant taxa of conservation concern are on or near these small and isolated forest openings that are believed to cover only about 250 acres (roughly 100 hectares) total, making them "one of the most significant reservoirs of botanical diversity in the eastern United States" (Allison and Stevens, 2001). Figure D-5 shows several rare plant taxa in Ketona dolomite glade habitat.

\section{Endemic and Biogeographically Disjunct Taxa}

Lawless and others (2006a) classified 13 taxa as being endemic or near-endemic to xeric limestone prairies, including 8 in the Ketona dolomite glades (Allison and Stevens, 2001; Alabama Natural Heritage Program, 2007), 4 from the Ozark Plateaus of Arkansas and Missouri, and 1 from the Valley and Ridge of Virginia and West Virginia. In addition to these taxa, Collins and Wieboldt (1992) described a new clover species (Trifolium calcaricum) found at only a few locations in xeric limestone prairies in southwestern Virginia and in Middle Tennessee. Kral and Moffett (2009) described a new speces, Xyris spathifolia, which has so far been documented only in Ketona dolomite glades. The Ketona dolomite glades also support populations of Solanum carolinense var. hirsutum, which was previously believed to be extinct (Allison and Stevens, 2001).

Near-endemic species of Appalachian shale barrens and of limestone cedar glades (such as Dalea gattingeri, Echinacea tennesseensis, and several varieties of Leavenworthia exigua) have also been found in xeric limestone prairies, with dispersal from cedar glades often facilitated by their geographic proximity to xeric limestone prairies (Lawless and others, 2006a). Other factors likely affecting the distribution of rare and endemic plants in xeric limestone prairies include topography, soil depth, size of forest openings (Skinner and others, 1983), competition with mesic species, and herbivory by insects (VanZandt and others, 2005). Although characteristic plant taxa of xeric limestone prairies do not necessarily show marked disjunction in their distributions, they do tend to have affinities with midwestern, western, and southwestern taxa, and for many species, xeric limestone prairies represent range extensions far to the east (Lawless and others, 2006a).

\section{Animal Taxa of Conservation Concern}

Xeric limestone prairies also provide eastern range extensions for a number of western and southwestern animal species, including Aphonopelma hentzi ${ }^{8}$ (Texas brown tarantula), Crotaphytus collaris (collared lizard), and Geococcyx californianus (greater roadrunner) (Kimmel and Probasco, 1980). Such range extensions contribute to regional faunal biodiversity by supporting taxa that are of local or regional conservation concern even though they are abundant in western regions. For example, whereas the collared lizard is globally secure within its range, it is ranked S3 in Arkansas (NatureServe, 2015) and is considered a species of conservation concern by the Arkansas Natural Heritage Commission (2014). Xeric limestone prairies provide important habitat to a number of other reptile and amphibian species, including Aspidoscelis sexlineata (six-lined racerunner), Plethodon glutinosus (northern slimy salamander), Plestiodon anthracinus (southern coal skink), Lampropeltis getula (eastern kingsnake), L. triangulum syspila (red milksnake), Sonora semiannulata (groundsnake), Lithobates sphenocephalus (southern leopard frog), Terrapene carolina (eastern box turtle), and Sceloporus undulatus (eastern fence lizard) (Kimmel and Probasco, 1980; Angert and others, 2002; VanZandt and others, 2005; Nelson and others, 2013). A number of grassland- and shrubland-associated birds have also been documented in xeric limestone prairies, including Peucaea aestivalis (Bachman's sparrow), Spizella pusilla (field sparrow), Setophaga discolor (prairie warbler), Setophaga cerulea (cerulean warbler), Vermivora cyanoptera (blue-winged warbler), Geothlypis formosa (Kentucky warbler), Passerina ciris (painted bunting), and Toxostoma rufum (brown thrasher) (Kimmel and Probasco, 1980; Hardin and others, 1982; Comer and others, 2011; Nelson and others, 2013). In the Ozarks, xeric limestone prairies support several rare invertebrates, including Trimerotropis saxatilis (lichen grasshopper). The Ketona dolomite glades support populations of Argyria rufisignella ${ }^{9}$, a rare moth species (Martinez and Brown, 2007), as well as several species of grasshoppers normally found in sandy habitats (Hill, 2007).

\footnotetext{
${ }^{8}$ Species name according to the Integrated Taxonomic Information System (2015).

${ }^{9}$ Species name according to Encyclopedia of Life (2016).
} 

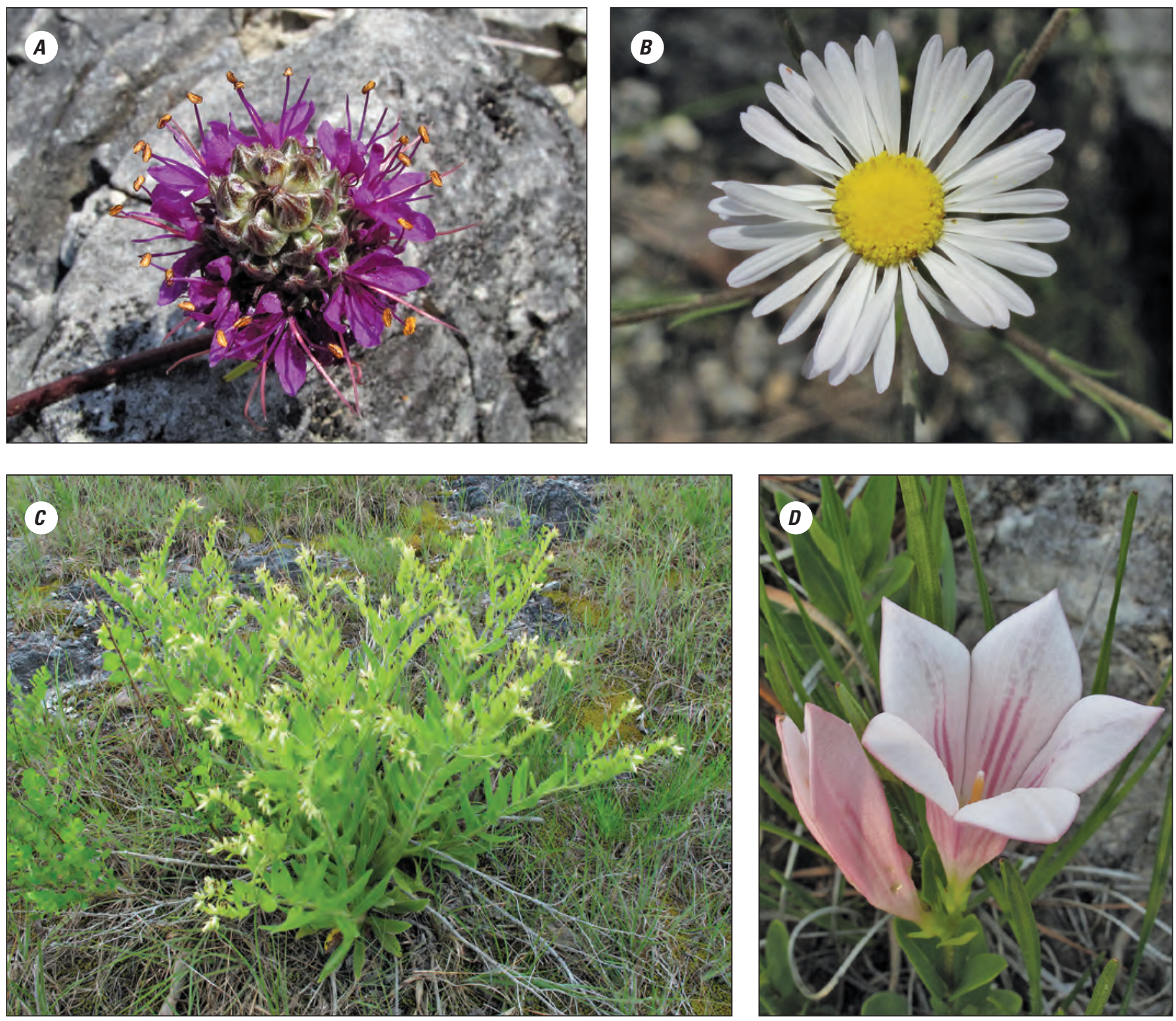

Figure D-5. Rare plant taxa in Ketona dolomite glades at the Kathy Stiles Freeland Bibb County Glades Preserve, Bibb County, Alabama: A, Dalea cahaba; B, Erigeron strigosus var. dolomiticola; $C$, Onosmodium decipiens; $D$, Spigelia gentianoides. Photographs by Alan M. Cressler, U.S. Geological Survey.

\section{Conservation Considerations}

In several states, xeric limestone prairies have been identified as key priorities for conservation and restoration (Laughlin, 2004; Cipollini and others, 2005; Nelson and others, 2013). Conservation of these ecosystems involves several considerations, including assessment of current threats, evaluation of various conservation strategies, and identification of gaps in scientific knowledge.

\section{Threats to Ecosystem Integrity}

Woody encroachment into xeric limestone prairies, largely attributable to fire suppression, is regarded by many researchers to be the primary threat to ecosystem health (Harper, 1920; Kimmel and Probasco, 1980; Annala and Kapustka, 1983; Skinner and others, 1983; Lowell and Astroth, 1989; Bartgis, 1993; Ware, 2002; Comer and others, 2011). Many researchers have recommended the reintroduction of fire into xeric limestone prairies in the form of prescribed burns to prevent woody encroachment, as well as the targeted removal of invasive exotic species and (or) the woody overstory if necessary (Lowell and Astroth, 1989; Laughlin, 2004; Jenkins and Jenkins, 2006; Duncan and others, 2008; Comer and others, 2011; Sutter and others, 2011). Woody invasive exotics mentioned as possible targets for removal include Ligustrum sinense, L. vulgare, Elaeagnus umbellata, Lonicera maackii, L. tatarica, and Rhamnus 
cathartica, and herbaceous exotics include Coronilla varia, Daucus carota, Lonicera japonica, Lespedeza cuneata, Bromus species, and Verbascum thapsus (Laughlin and Uhl, 2003; Laughlin, 2004; Sutter and others, 2011; Nelson and others, 2013). The shrinking of xeric limestone prairies by woody encroachment has implications not just for herbaceous endemic plant species, but also for grassland-associated birds, some of which are species of conservation concern (Kimmel and Probasco, 1980; Hardin and others, 1982; Comer and others, 2011; Nelson and others, 2013). For example, fire disturbance appears to be important in maintaining habitat for Bachman's sparrow, which has experienced noticeable population declines (Hardin and others, 1982; Meyer, 2006).

Land-use change, including conversion to agriculture and overgrazing, has been mentioned as a threat to some xeric limestone prairies (Hardin and others, 1982; Lowell and Astroth, 1989; Webb and others, 1997; Heikens, 1999; Rhoades and others, 2004; Young and others, 2009). In addition to direct effects on plant community composition, overgrazing can have indirect effects that ripple through the ecosystem, including soil compaction and disruption of interspecific interactions between plants and insects (Nelson and others, 2013). Some forms of resource extraction may also pose threats, including quarrying and logging (Bartgis, 1993; Webb and others, 1997; Heikens, 1999; Laughlin, 2004). Some sites have also been damaged by recreational use (Webb and others, 1997; Nelson and others, 2013). Increasingly, conservation officials have noted feral hogs to be a threat to some xeric limestone prairies in the Ozarks, causing erosion and reduction in plant and animal biodiversity (Nelson and others, 2013).

\section{Conservation Strategies}

Throughout their geographic range, a number of xeric limestone prairies are present on protected land. In southern Ohio, prairies are protected on the Richard and Lucile Durell Edge of Appalachia Preserve (Annala and Kapustka, 1983; Cipollini and others, 2005), and in Indiana they are within the Hoosier National Forest (Guyette and others, 2003). In Kentucky, the Crooked Creek Barrens Preserve (Rhoades and others, 2005), the Jim Scudder and Thompson Creek Glade nature preserves, the Fort Knox Military Reservation (Baskin and others, 1997), and the Bernheim Arboretum and Research Forest (Rhoades and others, 2004) all contain xeric limestone prairies. Most of the Ketona dolomite glades of Bibb County, Alabama, are now protected by the Nature Conservancy on its Kathy Stiles Freeland Bibb County Glades Preserve (Allison and Stevens, 2001). In the Ozarks of Missouri and Arkansas, xeric limestone prairies are present on numerous publicly protected sites, including Wilson's Creek National Battlefield (Young and others, 2009), Mark Twain National Forest (Kucera and Martin, 1957), Washington University’s Tyson Research Center, Meramec State Park (VanZandt and others, 2005), the Lower Buffalo Wilderness Area of the Buffalo National River (Jenkins and Jenkins, 2006), Taum Sauk Mountain State Park,
Butler Hollow Glade Natural Area (Nelson and others, 2013), and other protected sites.

Because woody encroachment is widely recognized as a major threat to xeric limestone prairies, many conservation programs involve attempts to preserve herbaceous habitat by mimicking natural disturbance regimes by using prescribed burns or other means of removing woody vegetation. A number of successful restoration projects have been described and empirically examined. Experimental prescribed burns in the Ketona dolomite glades and surrounding longleaf pine forest in Alabama produced considerable reduction in woody encroachment without any long-term detrimental effects on rare or endemic herbaceous species (Duncan and others, 2008). Prescribed burns in xeric limestone prairies in northern Arkansas also resulted in increased cover of prairie grasses and increased diversity of ground flora species, with increased diversity driven by increased evenness rather than increased richness (Jenkins and Jenkins, 2006). Following prescribed burns in Ozark xeric limestone prairies in Missouri, Comer and others (2011) noted a substantial shift in bird community structure toward grass-shrubland species, despite relatively subtle changes in vegetation structure. After the mechanical removal of Juniperus virginiana, Young and others (2009) documented a rapid response of the rare winter annual Lesquerella filiformis. In addition to removal of woody and exotic species, some xeric limestone prairie restoration projects have also involved planting of glade endemics, a practice that is most effective when juvenile plants are transplanted because seedling mortality is generally high and germination success low (VanZandt and others, 2005).

Although understanding of pre-settlement fire regimes is incomplete, evidence from tree-scar analysis suggests that prescribed burn practices will best mimic historical fire regimes if they incorporate spatially heterogeneous burning, low- to moderate-intensity fires, and variability in fire intervals (Guyette and others, 2003). Noting that some rare herbaceous species are able to colonize multiple microhabitats within xeric limestone prairies, Young and others (2009) recommended that management actions should be microhabitatspecific, for example by targeting burning to areas of heavy woody cover while focusing on reducing trampling at locations of shallower soil near outcrops. Different microhabitats for different rare xeric limestone prairie herbaceous species, as documented by Skinner and others (1983), also highlight the need to focus on microhabitat diversity as a part of management and conservation strategies. In assessing ecological effects of prescribed burning, Jenkins and Jenkins (2006) point out that unburned plots need to be included in experimental designs and analysis, rather than relying solely on pre-burn versus post-burn comparisons.

Additionally, restoration efforts to promote herbaceous habitat in xeric limestone prairies need to be based in a thorough understanding of trophic interactions, including the effects of herbivores and carnivores within the ecosystem. Specifically, Van Zandt and others (2005) recommended that when woody species are removed, downed logs, brush piles, 
and other similar structures should be preserved as refugia for carnivorous lizards that indirectly protect herbaceous plants by feeding upon insect herbivores. This type of conservation planning based on expected trophic interactions can be complicated, however, involving an accounting for multiple factors governing the population structures of insectivorous lizards in xeric limestone prairies, such as competition, predation, thermal biology, and differential microhabitat use (Angert and others, 2002).

\section{Knowledge Gaps}

The conservation of xeric limestone prairies is rarely straightforward, for a number of reasons. The origins of these prairies and the relative importance of factors involved in their maintenance are still debated. The ambiguous definition of ecological integrity for xeric limestone prairies complicates conservation decisionmaking and prioritization. Effective management and conservation of fire-maintained ecosystems require thorough understanding of the relevant historical disturbance regimes (Guyette and others, 2003); however, the timing, frequency, and intensity of fire regimes predating European settlement are not fully understood. Research efforts are often complicated by problems such as the disappearance of fire evidence from decomposition in humid climates, the difficulty in finding undisturbed lake sediments for analysis, and inherent biases in fire-scar analysis of trees (Guyette and others, 2003; Laughlin and Uhl, 2003; Laughlin, 2004; Cipollini and others, 2005). Also lacking is a thorough understanding of how fire in xeric limestone prairies affects population dynamics of animal species (Heikens, 1999) and of rare and endemic plants (Duncan and others, 2008), or of the interaction between fire regime and topography and substrate (Batek and others, 1999).

\section{Possible Ecological Effects from Climate Change}

A systematic climate-change vulnerability analysis across the full range of xeric limestone prairie community types has yet to be conducted; however, some species-level analyses have included taxa associated with xeric limestone prairies. For example, Davenport (2007) predicted that Dalea foliosa and Spigelia gentianoides "would suffer greatly under drier conditions and perhaps disappear entirely." Molano-Flores and Bell (2012) used count-based population viability analysis to project population dynamics of $D$. foliosa based on various climate-change scenarios. Warmer winter temperatures and associated reductions in snow cover were projected to contribute to population declines, which was attributed to diminished insulation under cold conditions and premature snowmelt-triggered dehardening, leading to root injury and seedling mortality. This study used approximately one decade's worth of population data, such that long-term climate-related ecosystem-level effects on habitat (such as changes in disturbance regime, changes in woody cover, or changes in soil physical or chemical properties) likely were not accounted for. Also, the data were obtained from a single site near the northern limit of the species range, so applicability of findings to other $D$. foliosa populations is unclear.

Such analyses may be useful in forecasting population dynamics based on the interactions of climate change and species-level physiology (for example, seedling mortality increased by early snowmelt), but cannot account for species vulnerability to climate change that derives primarily from habitat degradation. Habitat-based vulnerability may be important, however, because analysis of microhabitat characteristics of $D$. foliosa suggests this species is sensitive to woody encroachment and to competition with other herbaceous plants (Thompson and others, 2006). Thus, an analysis of climate-related habitat alteration would likely improve predictive power of models for climate-change effects on populations of this rare plant - and others with similar habitat needs - present in xeric limestone prairies.

Predicting ecosystem-level climate-change effects for xeric limestone prairies is complicated by ambiguity over the relative importance of disturbance regimes and of topo-edaphic stress factors, as well as by the complex interactions between the two. In the absence of human interference, climate is generally a strong control on fire intervals (Guyette and others, 2012). If climate change produces higher summer temperatures, drier summer conditions, and (or) more frequent or longer droughts, then natural fire frequency and intensity would be expected to increase. Below certain temperature-dependent precipitation thresholds, however, dry conditions can limit fuel availability (Guyette and others, 2012). If drought intensification reduced woody and (or) herbaceous cover within xeric limestone prairies or their immediate surroundings, reduced fuel loads could limit fire frequency and intensity. Additionally, changes in seasonal storm frequency could be an important factor to the degree that lightning strikes are an ignition source. Thus, fire-regime effects from climate change - even under an assumption of drought intensification - might be difficult to predict. Of course, for many xeric limestone prairies, this would be a moot point because fire regimes have already been highly modified through fire suppression and (or) controlled burning (Kucera and Martin, 1957; Ware, 2002; Comer and others, 2011; Nelson and others, 2013), implying that the possibility for climate change to alter ecosystem dynamics through fire-regime alteration has been greatly diminished.

Even in the absence of fire-regime effects, regional changes in precipitation timing, frequency, and intensity could produce ecological changes in xeric limestone prairies. As with limestone cedar glades, plant taxa associated with seasonally wet microhabitats (Taylor and Estes, 2012) and those with life histories timed to historical seasonal patterns in soil moisture availability (Quarterman, 1950; Ware, 2002) might be especially sensitive to changes in the seasonal timing of precipitation inputs. Additionally, changes in storm intensity, duration, or seasonality could have implications for soil erosion dynamics in xeric limestone prairies. Thornberry-Ehrlich (2012) discussed the potential for greater 
erosion in Stones River National Battlefield in Rutherford County, Tennessee - a site containing xeric limestone prairies closely associated with limestone cedar glades — resulting from predicted increases in storm frequency and intensity. The degree to which changes in storm dynamics might be associated with increased erosion in xeric limestone prairies would likely be based on a number of interrelated and sitespecific factors including soil texture, slope, and vegetation cover (Ware, 2002; Lawless and others, 2006a) as well as disturbance history (Trammell and others, 2004).

\section{References}

Alabama Natural Heritage Program, 2007, Alabama inventory list-The rare, threatened and endangered plants and animals of Alabama: Montgomery, Ala., Alabama Natural Heritage Program.

Allison, J., 1994, A botanical "lost world" in central Alabama, in Proceedings of the North American Conference on Savannas and Barrens, Environmental Protection Agency, Great Lakes National Program Office, Chicago, Ill., p. 323-327.

Allison, J., and Stevens, T., 2001, Vascular flora of Ketona dolomite outcrops in Bibb County, Alabama: Castanea, v. 66 , no. 1, p. 154-205.

Angert, A., Hutchison, D., Glossip, D., and Losos, J., 2002, Microhabitat use and thermal biology of the collared lizard (Crotaphytus collaris collaris) and the fence lizard (Sceloporus undulatus hyacinthinus) in Missouri glades: Journal of Herpetology, v. 36, no. 1, p. 23-29.

Annala, A., and Kapustka, L., 1983, Photographic history of forest encroachment in several relict prairies of the Edge of Appalachia preserve system, Adams County, Ohio: Ohio Journal of Science, v. 83, no. 3, p. 109-114.

Arkansas Natural Heritage Commission, 2014, Rare species search engine-Find Arkansas species of conservation interest, accessed November 18, 2015, at http://www.natural heritage.com/Research-and-Data/rare-species-search.

Bartgis, R., 1993, The limestone glades and barrens of West Virginia: Castanea, v. 58, no. 2, p. 69-89.

Baskin, J., and Baskin, C., 1999, Cedar glades of the southeastern United States, in Anderson, R., Fralish, J., and Baskin, J., eds., Savannas, barrens, and rock outcrop plant communities of North America: New York, Cambridge University Press, p. 206-219.
Baskin, J., and Baskin, C., 2000, Vegetation of limestone and dolomite glades in the Ozarks and Midwest regions of the United States: Annals of the Missouri Botanical Garden, v. 87 , no. 2 , p. $286-294$.

Baskin, J., and Baskin, C., 2003, The vascular flora of cedar glades of the southeastern United States and its phytogeographical relationships: Journal of the Torrey Botanical Society, v. 130, no. 2, p. 101-118.

Baskin, J., and Baskin, C., 2004, History of the use of "cedar glades" and other descriptive terms for vegetation on rocky limestone soils in the Central Basin of Tennessee: The Botanical Review, v. 70, no. 4, p. 403-424.

Baskin, J., Baskin, C., and Chester, E., 1999, The Big Barrens Region of Kentucky and Tennessee, in Fralish, J., and Baskin, J., eds., Savannas, barrens, and rock outcrop plant communities of North America: New York, Cambridge University Press, p. 190-205.

Baskin, J., Baskin, C., and Lawless, P., 2007a, Calcareous rock outcrop vegetation of eastern North America (exclusive of the Nashville Basin), with particular reference to use of the term "cedar glades": The Botanical Review, v. 73, no. 4, p. 303-325.

Baskin, J., Baskin, C., and Quarterman, E., 2007b, Flow diagrams for plant succession in the Middle Tennessee cedar glades: Journal of the Botanical Research Institute of Texas, v. 1, no. 2, p. 1131-1140.

Baskin, J., Chester, E., and Baskin, C., 1997, Special paperForest vegetation of the Kentucky karst plain (Kentucky and Tennessee) - Review and synthesis: Journal of the Torrey Botanical Society, v. 124, no. 4, p. 322-335.

Batek, M., Rebertus, A., Schroeder, W., Haithcoat, T., Compas, E., and Guyette, R., 1999, Reconstruction of early nineteenth-century vegetation and fire regimes in the Missouri Ozarks: Journal of Biogeography, v. 26, no. 2, p. 397-412.

Belden, A., Chazal, A., and Hobson, C., 2003, A natural heritage inventory of fourteen headwater sites in the Dragon Run Watershed: Richmond, Va., Virginia Department of Conservation and Recreation.

Cipollini, K., Maruyama, A., and Zimmerman, C., 2005, Planning for restoration-A decision analysis approach to prioritization: Restoration Ecology, v. 13, no. 3, p. 460-470.

Collins, J., and Wieboldt, T., 1992, Trifolium calcaricum (Fabaceae), a new clover from limestone barrens of eastern United States: Castanea, v. 57, no. 4, p. 282-286. 
Comer, C., Bell, A., Oswald, B., Conway, W., and Burt, D., 2011, Vegetation and avian response to prescribed fire on glade habitats in the Missouri Ozarks: The American Midland Naturalist, v. 165, no. 1, p. 91-104.

Copenheaver, C., Kyle, K., Stevens, G., and Kamp, M., 2005, Comparing Juniperus virginiana tree-ring chronologies from forest edge vs. forest interior positions in the Cedars Natural Area Preserve in Virginia, USA: Dendrochronologia, v. 23, no. 1, p. 39-45.

Davenport, L., 2007, Climate change and its potential effects on Alabama's plant life: Birmingham, Ala., Samford University, Vulcan Materials Center for Environmental Stewardship and Education.

DeSelm, H., and Murdock, N., 1993, Grass-dominated communities, in Martin, W., Boyce, S., and Echternacht, A., eds., Biodiversity of the southeastern United StatesUpland terrestrial communities: New York, John Wiley and Sons, Inc., p. 87-141.

DeSelm, H., Whitford, P., and Olson, J., 1969, The barrens of the Oak Ridge area, Tennessee: American Midland Naturalist, v. 81, no. 2, p. 315-330.

Duncan, R., Anderson, C., Sellers, H., and Robbins, E., 2008, The effect of fire reintroduction on endemic and rare plants of a southeastern glade ecosystem: Restoration Ecology, v. 16 , no. 1 , p. $39-49$.

Encyclopedia of Life, 2016, Encyclopedia of Life, accessed February 18, 2016, at http://www.eol.org.

Erickson, R., Brenner, L., and Wraight, J., 1942, Dolomitic glades of east-central Missouri: Annals of the Missouri Botanical Garden, v. 29, no. 2, p. 89-101.

Fenneman, N., 1938, Physiography of the Eastern United States: New York, McGraw-Hill.

Fenneman, N., and Johnson, D., 1946, Physical divisions of the United States: U.S. Geological Survey map prepared in cooperation with the Physiographic Commission, scale $1: 7,000,000$.

Foti, T., and Glenn, S., 1991, The Ouachita Mountain landscape at the time of settlement, in Restoration of old growth forests in the interior highlands of Arkansas and Oklahoma: Proceedings of the 1990 Conference: Morrilton, Ark., Winrock International Institute for Agricultural Development, p. 49-66.

Guyette, R., Dey, D., and Stambaugh, M., 2003, Fire and human history of a barren-forest mosaic in southern Indiana: American Midland Naturalist, v. 149, p. 21-34.
Guyette, R., Stambaugh, M., Dey, D., and Muzika, R., 2012, Predicting fire frequency with chemistry and climate: Ecosystems, v. 15, no. 2, p. 322-335.

Hall, M., 1955, Comparison of Juniper populations on an Ozark glade and old fields: Annals of the Missouri Botanical Garden, v. 42, no. 2, p. 171-194.

Hardin, K., Baskett, T., and Evans, K., 1982, Habitat of Bachman's Sparrows breeding on Missouri glades: The Wilson Bulletin, v. 94, no. 2, p. 208-212.

Harper, R., 1920, The limestone prairies of Wilcox County, Alabama: Ecology, v. 1, no. 3, p. 198-203.

Heikens, A., 1999, Savanna, barrens, and glade communities of the Ozark Plateaus Province, in Anderson, R., Fralish, J., and Baskin, J., eds., Savannas, barrens, and rock outcrop plant communities of North America: New York, Cambridge University Press, p. 220-230.

Heikens, A., and Robertson, P., 1994, Barrens of the Midwest-A review of the literature: Castanea, v. 59, no. 3, p. 184-194.

Heikens, A., and Robertson, P., 1995, Classification of barrens and other natural xeric forest openings in southern Illinois: Bulletin of the Torrey Botanical Club, v. 122, no. 3, p. 203-214.

Hill, J., 2007, The grasshoppers (Orthoptera: Acrididae) of the Bibb County Glades, Alabama: Marginalia Insecta, v. 2 , no. 1, p. 1-3.

Homoya, M., 1994, Indiana barrens-Classification and description: Castanea, v. 59, no. 3, p. 204-213.

Integrated Taxonomic Information System, 2015, The Integrated Taxonomic Information System, accessed October 5, 2015, at http://www.itis.gov.

Jenkins, S., Guyette, R., and Rebertus, A., 1997, Vegetationsite relationships and fire history of a savanna-glade-woodland mosaic in the Ozarks: Proceedings of the 11th Central Hardwood Forest Conference.

Jenkins, S., and Jenkins, M., 2006, Effects of prescribed fire on the vegetation of a savanna-glade complex in northern Arkansas: Southeastern Naturalist, v. 5, no. 1, p. 113-126.

Kimmel, V., and Probasco, G., 1980, Change in woody cover on limestone glades between 1938 and 1975: Transactions of the Missouri Academy of Science, v. 14, p. 69-74.

Kral, R., and Moffett, J., 2009, Xyris spathifolia (Xyridaceae), a new xyrid from the Ketona dolomite-limestone glades of Alabama: Journal of the Botanical Research Institute of Texas, v. 3, no. 2, p. 469-478. 
Kucera, C., and Martin, S., 1957, Vegetation and soil relationships in the glade region of the southwestern Missouri Ozarks: Ecology, v. 38, no. 2, p. 285-291.

Laughlin, D., 2004, Woody plant invasion and the importance of anthropogenic disturbance within xeric limestone prairies: Journal of the Pennsylvania Academy of Science, v. 78 , no. 1, p. $12-28$.

Laughlin, D., and Uhl, C., 2003, The xeric limestone prairies of Pennsylvania: Castanea, v. 68, no. 4, p. 300-316.

Lawless, P., Baskin, J., and Baskin, C., 2004, The floristic ecology of xeric limestone prairies in Kentucky, and a comparison to limestone cedar glades and deep-soil barrens: Sida, v. 21, no. 70, p. 1055-1079.

Lawless, P., Baskin, J., and Baskin, C., 2006a, Xeric limestone prairies of eastern United States: review and synthesis: The Botanical Review, v. 72, no. 3, p. 235-272.

Lawless, P., Baskin, J., and Baskin, C., 2006b, Scaledependent classification of xeric limestone prairiesAnnual or perennial grasslands?: Annals of the Missouri Botanical Garden, v. 93, no. 3, p. 455-464.

Lowell, K., and Astroth, J., 1989, Vegetative succession and controlled fire in a glades ecosystem: a geographical information system approach: International Journal of Geographical Information Systems, v. 3, no. 1, p. 37-41.

Ludwig, J., 1999, The flora of dolomite and limestone barrens in southwestern Virginia: Castanea, v. 64, no. 3, p. 209-230.

Mann, L., King, A., Dale, V., Hargrove, W., WashingtonAllen, R., Pounds, L., and Ashwood, T., 1999, The role of soil classification in geographic information system modeling of habitat pattern-Threatened calcareous ecosystems: Ecosystems, v. 2, p. 524-538.

Martinez, E., and Brown, R., 2007, Argyriini (Lepidoptera: Crambidae) of Mississippi and Alabama with a rediscription of Argyria rufisignella (Zeller): Journal of the Lepidopterists' Society, v. 61, no. 2, p. 78-83.

Meyer, R., 2006, Aimophila aestivalis: Fire Effects Information System (Online), U.S. Department of Agriculture, Forest Service, Rocky Mountain Research Station, Fire Sciences Laboratory, accessed August 27, 2015, at http://www.fs.fed.us/database/feis/animals/bird/aiae/all.html.

Mills, J., 2008, Fifty years of change in Wisconsin cedar glades: The American Midland Naturalist, v. 159, no. 1, p. 214.
Molano-Flores, B., and Bell, T., 2012, Projected population dynamics for a federally endangered plant under different climate change emission scenarios: Biological Conservation, v. 145 , no. 1 , p. 130-138.

Morris, L., Walck, J., and Hidayati, S., 2002, Reproduction of the invasive Ligustrum sinense and native Forestiera ligustrina (Oleaceae)-Implications for the invasion and persistence of a nonnative shrub: International Journal of Plant Sciences, v. 163, no. 6, p. 1001-1010.

NatureServe, 2015, NatureServe Explorer-An online encyclopedia of life [web application], ver. 7.1, accessed October 7, 2015, at http://www.natureserve.org/explorer.

Nelson, P., Fitzgerald, J., Larson, K., McCoy, R., Schotz, A., Taft, J., Witsell, T., and Yahn, B., 2013, Central hardwoods joint venture glade conservation assessment for the Interior Highlands and Interior Low Plateaus of the central hardwoods region: Central Hardwoods Joint Venture.

Noss, R., 2013, Forgotten grasslands of the south: Washington, D.C., Island Press.

Quarterman, E., 1950, Ecology of cedar glades. I. Distribution of glade flora in Tennessee: Bulletin of the Torrey Botanical Club, v. 77, no. 1, p. 1-9.

Quarterman, E., 1989, Structure and dynamics of the limestone cedar glade communities in Tennessee: Journal of the Tennessee Academy of Science, v. 64, no. 3, p. 155-158.

Quarterman, E., Burbanck, M., and Shure, D., 1993, Rock outcrop communities - Limestone, sandstone, and granite, in Martin, W., Boyce, S., and Echternacht, A., eds., Biodiversity of the southeastern United States-Upland terrestrial communities: New York, John Wiley and Sons, Inc., p. 35-86.

Rhoades, C., Miller, S., and Shea, M., 2004, Soil properties and soil nitrogen dynamics of prairie-like forest openings and surrounding forests in Kentucky's Knobs Region: The American Midland Naturalist, v. 152, no. 1, p. 1-11.

Rhoades, C., Miller, S., and Skinner, D., 2005, Forest vegetation and soil patterns across glade-forest ecotones in the Knobs region of northeastern Kentucky, USA: The American Midland Naturalist, v. 154, no. 970, p. 1-10.

Sauer, C., 1950, Grassland climax, fire, and man: Journal of Range Management, v. 3, no. 1, p. 16-21.

Skinner, B., Probasco, G., and Samson, F., 1983, Environmental requirements of three threatened plants on limestone glades in southern Missouri: Biological Conservation, v. 25, p. 63-73. 
Sutter, R., Govus, T., Smyth, R., Nordman, C., Pyne, M., and Hogan, T., 2011, Monitoring change in a central U.S. calcareous glade-Resampling transects established in 1993: Natural Areas Journal, v. 31, no. 2, p. 163-172.

Taylor, K., and Estes, D., 2012, The floristic and community ecology of seasonally wet limestone glade seeps of Tennessee and Kentucky: Journal of the Botanical Research Institute of Texas, v. 6, no. 2, p. 711-724.

Thompson, J., Walck, J., and Hidayati, S., 2006, Microhabitat requirements of the federally endangered Dalea foliosa, with recommendations on establishment of new populations: Castanea, v. 71, no. 2, p. 94-104.

Thornberry-Ehrlich, T., 2012, Stones River National Battlefield-Geological resources inventory report: Fort Collins, Colo., Natural Resource Report NPS/NRSS/GRD/NRR.

Trammell, T., Rhoades, C., and Bukaveckas, P., 2004, Effects of prescribed fire on nutrient pools and losses from glades occurring within oak-hickory forests of Central Kentucky: Restoration Ecology, v. 12, no. 4, p. 597-604.
Van Zandt, P., Collins, E., Losos, J., and Chase, J., 2005, Implications of food web interactions for restoration of Missouri Ozark glade habitats: Restoration Ecology, v. 13, no. 2, p. 312-317.

Ware, S., 2002, Rock outcrop plant communities (glades) in the Ozarks - A synthesis: The Southwestern Naturalist, v. 47 , no. 4 , p. 585-597.

Ware, S., 2010, Croton monanthogynus and Crotonopsis elliptica (Euphorbiaceae) in Ozark rock outcrop communities-Abundance, soil depth, and substrate tolerance: Northeastern Naturalist, v. 17, no. 4, p. 659-666.

Webb, D., DeSelm, H., and Dennis, W., 1997, Studies of prairie barrens of northwestern Alabama: Castanea, v. 62, no. 3, p. 173-184.

Young, C., Morrison, L., and Haack, J., 2009, Habitat relationships and management implications for Lesquerella filiformis Rollins (Missouri bladderpod) on a xeric limestone prairie: The Journal of the Torrey Botanical Society, v. 136 , no. 2 , p. 233-241. 



\section{Chapter E. Mid-Appalachian Shale Barrens}

\section{Introduction}

Shale barrens of the mid-Appalachian region (fig. E-1) are forest openings with scattered shrubs and patches of herbaceous vegetation interspersed with bedrock outcrops supporting bryophyte and lichen communities (Norris and Sullivan, 2002). Stunted trees, including Quercus, Pinus, and Carya species and Juniperus virginiana, are sparsely distributed, resulting in shale barrens typically having a moderately open canopy with mostly woody vegetation and a relatively sparse herbaceous understory (Clarkson, 1966; Braunschweig and others, 1999). These shale barrens support a number of taxa of conservation concern, including several endemic plant taxa that display specialized adaptations to tolerate the abiotic stress regime of shale barren environments.

\section{Geographic Range}

Mid-Appalachian shale barrens are present within the Valley and Ridge Physiographic Province of the Appalachian Highlands (Fenneman and Johnson, 1946) in south-central Pennsylvania, western Maryland, eastern West Virginia, and southwestern Virginia (Keener, 1983; Morse, 1983; Braunschweig and others, 1999). Norris and Sullivan (2002) estimated the number of shale barrens to be 25 in Pennsylvania, 35 in Maryland, 800 in Virginia, and 100 in West Virginia, although they acknowledged that the accuracy of these counts might be affected by ambiguities over the definition of shale barrens as an ecosystem type. The greatest concentration of shale barrens is within a zone lying along the southern part of the border between Virginia and West Virginia (Norris and Sullivan, 2002). Figure E-2 shows a map of the general geographic distribution of mid-Appalachian shale barrens.

Within this region of the Appalachian Highlands, shale barrens are primarily associated with Upper Devonian strata of shale including the Brallier Shale, the Romney Shale, and the Trimmers Rock Formation (Artz, 1948; Platt, 1951; Core, 1952; Keener, 1983; Morse, 1983), although they have also been described on the Martinsburg Formation of Ordovician strata in the Massanutten Mountains of Virginia (Artz, 1937) and on the Rose Hill Formation of Silurian strata in Maryland (Morse, 1983).

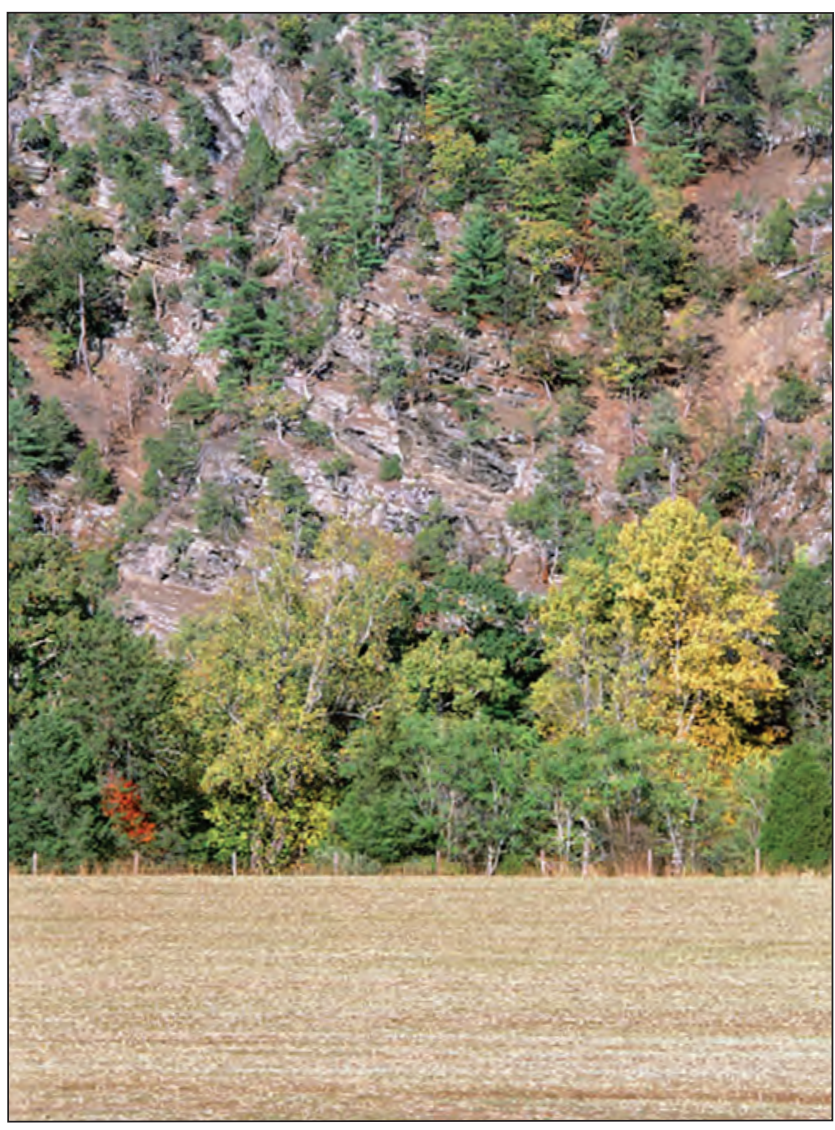

Figure E-1. Shale barren above a cowpasture, Bath County, Virginia. Photograph by Gary Fleming, Virginia Department of Conservation and Recreation.

Rawinski and others (1996) described shale barrens with a similar suite of endemics in the Blue Ridge Physiographic Province and argued that these constitute a subtype known as Blue Ridge shale barrens. Although mid-Appalachian shale barrens share some physical and physiognomic features (such as shallow soil, open canopy, and prevalence of herbaceous vegetation) with shale barrens in other parts of the United States such as in Illinois, they are clearly distinct from Midwest shale barrens at a floristic level, as evidenced by a suite of species endemic only to the mid-Appalachian barrens (Heikens and others, 1994; McCall and Gibson, 1999; West and others, 2009). 


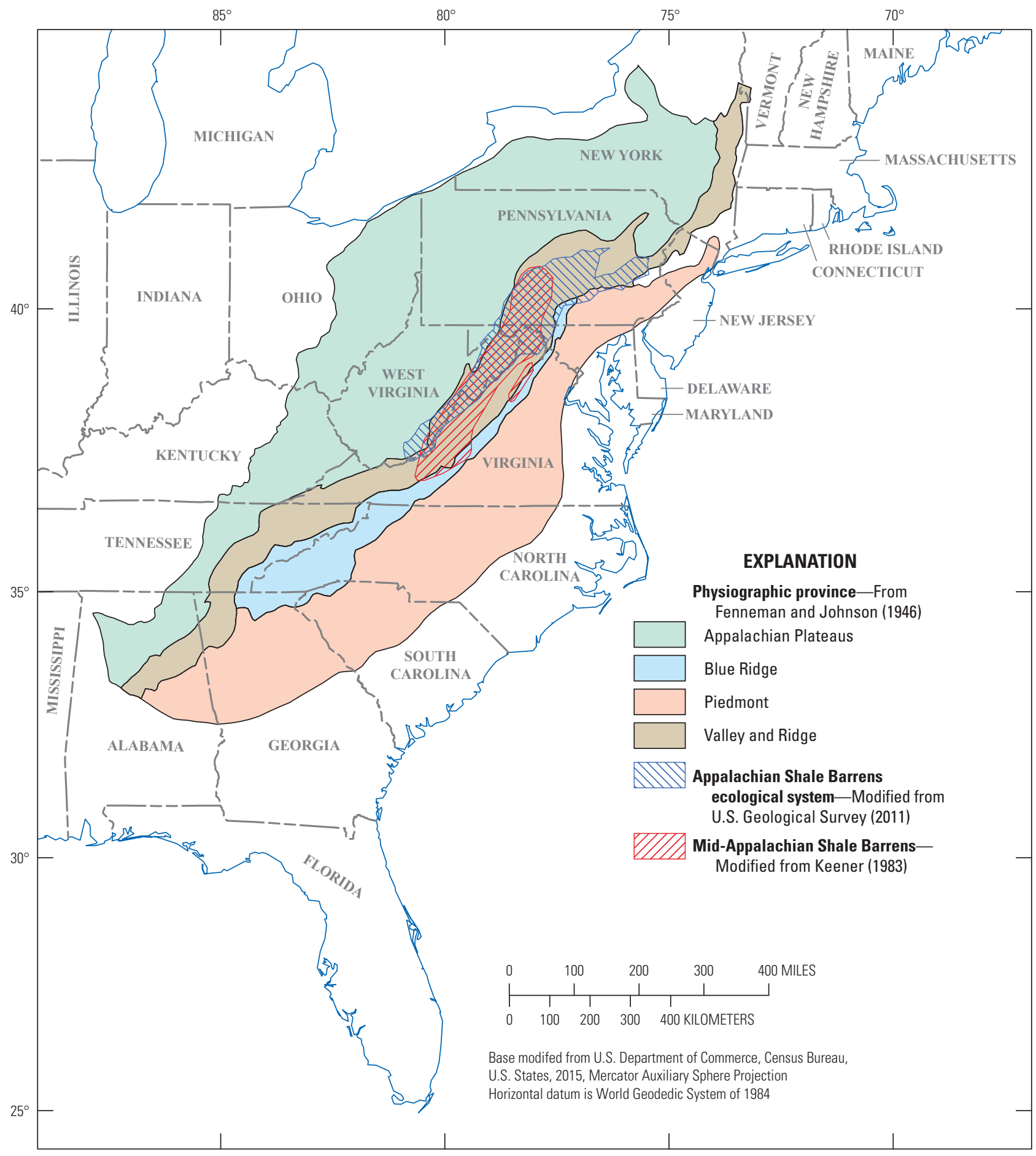

Figure E-2. General geographic distribution of mid-Appalachian shale barrens. 


\section{Physical Geography}

Mid-Appalachian shale barrens typically are present at elevations ranging from approximately 1,000 to 1,900 feet (about 300 to 575 meters) on steep (20-40 percent) slopes (Platt, 1951; Keener, 1983; Braunschweig and others, 1999). Figure E-3 shows a shale barren with characteristically steep slope. Widespread agreement exists that the spatial distribution of mid-Appalachian shale barrens is highly influenced by topographic position on the landscape (especially slope and aspect), which is in turn determined largely by geophysical and geographic factors (Allard and Leonard, 1946; Platt, 1951; Keener, 1983; Braunschweig and others, 1999). Within areas of varying topography, shale barrens are present more frequently on east-, south-, and west-facing slopes, while adjacent areas of level terrain or north-facing slopes are more likely to be forested, implying that slope and aspect are important - though probably not exclusive - determinants of shale barren formation (Braunschweig and others, 1999). Allard and Leonard (1946) argued that the steep slopes upon which shale barrens typically develop are produced by a combination of erosion-resistant sandstone ridge-caps upslope and stream action undercutting the hillside downslope, indicating thatin addition to bedrock geology - proximity to streams and the hydrologic and geomorphic characteristics of those streams are additional factors helping to create the topographic contexts in which shale barrens may develop. An example of a shale barren undercut by a stream is shown in figure $\mathrm{E}-4$.

Platt (1951) questioned this conceptualization of shale barren development, noting that (1) softer shales in the region with similar geographic and geologic conditions do not produce barrens, (2) more barrens develop away from streams than near them, for example on the flanks of ridges, and (3) the perception that undercutting stream action is necessary for shale barren formation might be attributable to observational bias because barrens are often viewed from roads, which commonly are parallel to streams. Despite these assertions, recent publications - such as Braunschweig and others (1999) - have continued to maintain that undercutting stream action is an important factor in creating and maintaining shale barrens.

Shale barren soils are typically overlain by a surface layer of weather-resistant shale fragments and typically have little organic litter at the soil surface (Keener, 1983; Braunschweig and others, 1999). Platt (1951) suggested that this surface

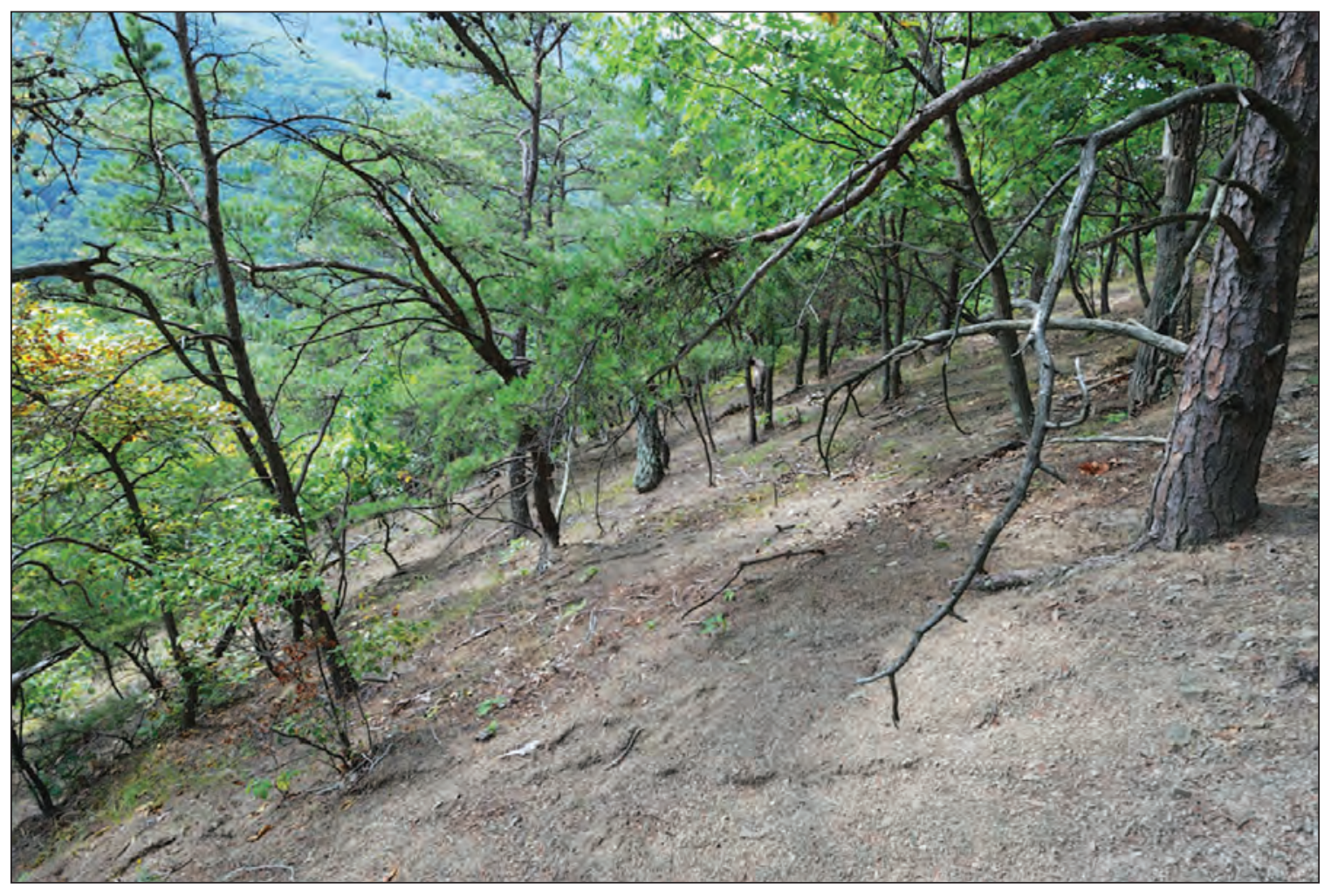

Figure E-3. Shale barren, Edinburg Gap, George Washington and Jefferson National Forests, Shenandoah County, Virginia. Photograph by Gary Fleming, Virginia Department of Conservation and Recreation. 


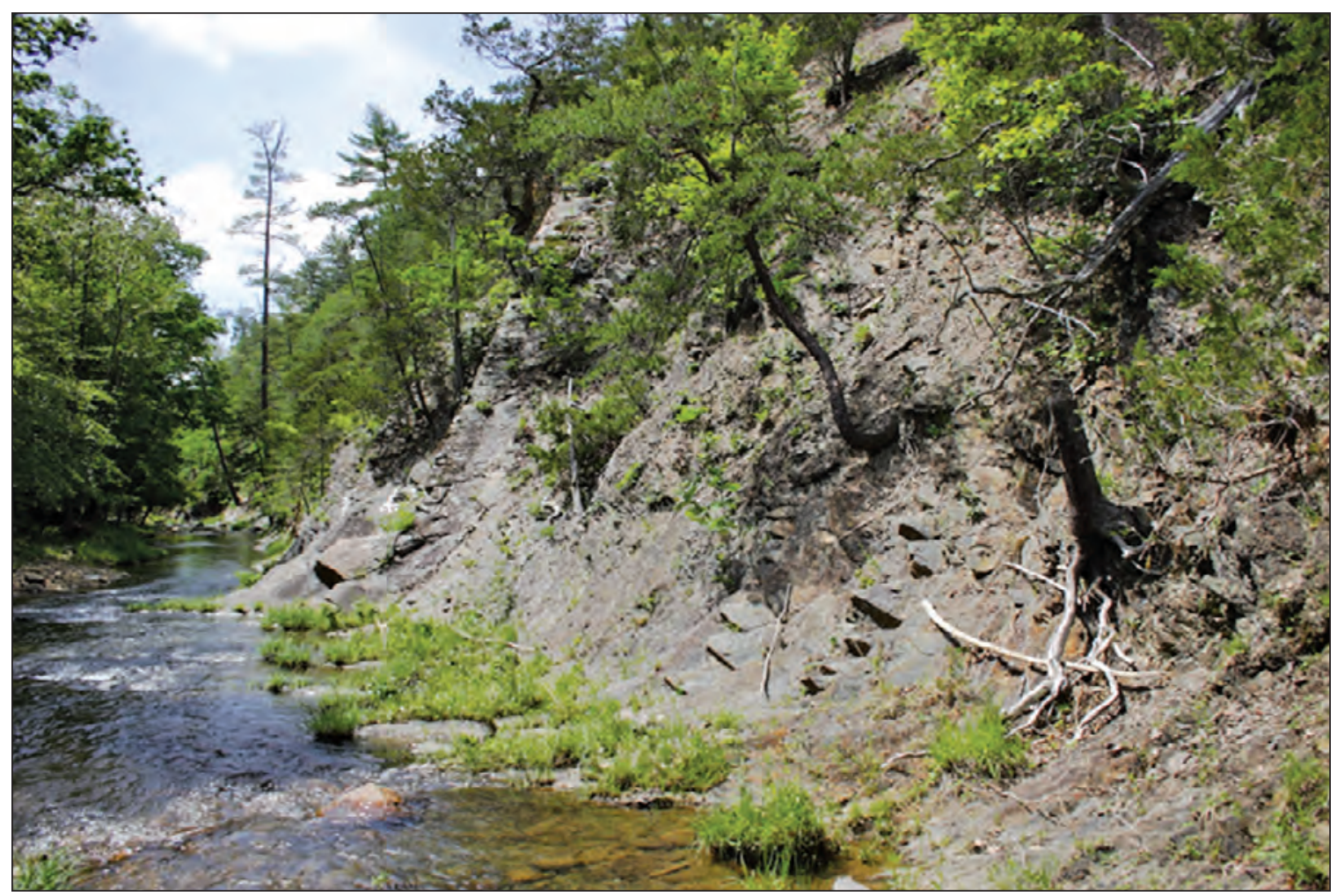

Figure E-4. Shale barren undercut by a stream, Bath County, Virginia. Photograph by Irvine Wilson, Virginia Department of Conservation and Recreation.

layer of shale fragments provided insulation to the soil below, partially shielding it from the drying effects of wind and direct sunlight. Below this surface layer, he also noted poor differentiation of the horizons within the soil profile of shale barrens on the Brallier Shale and the general lack of a B horizon. Although these characteristics of shale barren soils make them atypical for the region, their moderately acidic $\mathrm{pH}$ and the availability of certain inorganic nutrients is comparable to the soils of nearby forested sites (Braunschweig and others, 1999).

\section{Stress and Disturbance Regimes}

The exact nature of the stress regime characteristics of mid-Appalachian shale barrens has been the subject of some debate. Several generations of researchers have attributed the existence of shale barren communities to a lack of soil nutrients resulting from an absence of true soil due to erosion (Allard and Leonard, 1946; Keener, 1983). Platt (1951), however, concluded that shale barrens "are not the subject of extreme erosion" and discounted erosion as a major factor in forming or maintaining shale barren ecosystems, citing evidence such as the lack of erosional gullies and observations from dye experiments of sheet flow moving primarily over resistant rock fragments rather than over soil. Relatively recent publications, including Braunschweig and others (1999) and the U.S. Forest Service (2011), have asserted that surficial shale fragments continually migrate downslope such that the ground surface of shale barrens is "constantly shifting" (Nott, 2006), but they did not present empirical evidence to support these claims. Platt (1951), however, did empirically investigate this possibility. Through a simple experiment involving stripes spray-painted along contour lines across shale barrens, he found the stripes to be almost wholly intact after 10 months, with the exception of a few small washes, indicating minimal downslope migration of shale fragments over the course of his study. He also pointed to the lack of accumulated rock fragments at the downslope bases of shale barrens and to the presence of lichen communities atop shale fragment surfaces as further evidence in contradiction to the idea of a highly unstable ground surface. It appears that although Platt (1951) presented empirical evidence against the premise of erosion (either of soil or of surficial rock fragments) as a primary component of the shale barren stress regime, this concept has nonetheless been perpetuated by subsequent generations of investigators.

Similarly, the degree and type of water stress experienced by shale barren vegetation have been debated. It has been noted that the geographic area in which shale barrens are clustered experiences relatively less rainfall than the surrounding region because it lies in the rain shadow of the Allegheny Front, which extends from central Pennsylvania to eastern West Virginia (Clarkson, 1966; Norris and Sullivan, 2002). Platt (1951), however, observed that hillsides adjacent 
to shale barrens receiving comparable precipitation are forested, indicating that lack of precipitation alone cannot account for barren formation and maintenance. Platt (1951) also empirically discredited earlier notions that low levels of soil nutrients or soil moisture throughout the soil profile are primary determinants of the structure of shale barren communities. Platt (1951) demonstrated that for shale barren soils, "the depth of the $\mathrm{C}$ horizon, as well as its moisture and nutrient content, is essentially similar to that of the vegetated slopes," and asserted that the $\mathrm{C}$ horizon maintains sufficient moisture (largely due to the insulating effects of the shale fragments at the soil surface) to sustain species adapted to exploiting it. However, he also demonstrated that the evaporative power of air over shale barrens was more than twice that for adjacent north-facing slopes, with temperature having a disproportionately high effect on evaporation for shale barren sites. Thus, Platt (1951) concluded that surficial hydrologic conditions were indeed xeric in shale barrens for at least part of the growing season.

Generally, more recent publications (for example, Keener, 1983; Braunschweig and others, 1999; Norris and Sullivan, 2002) have rejected the earlier assumption that below-ground resources - subsurface moisture, geochemistry, and nutrients - are the primary limiting factors in midAppalachian shale barren habitats (Allard and Leonard, 1946), and have instead focused on the microenvironment at the soil surface. Braunschweig and others (1999) suggested that the nutrient limitation that might exist could take the form of reduced organic matter or nitrate availability in the A horizon. In particular, high insolation, high temperature (up to $63{ }^{\circ} \mathrm{C}$ ), and xeric conditions at the soil surface - resulting from topography (slope and aspect) and lack of canopy cover-are the primary components of the stress regime experienced by shale barren species, with this stress most acutely affecting germinating seeds and seedlings (Platt, 1951; Keener, 1983; Braunschweig and others, 1999; Norris and Sullivan, 2002).

Certain forms of disturbance may contribute to shale barren maintenance. Anthropogenic disturbance, such as from logging or grazing, is thought to be of minimal importance to the maintenance of ecosystem integrity overall, though some shale barrens may show evidence of previous grazing (Braunschweig and others, 1999). Fire is not believed to be a major factor in creating or maintaining shale barrens, largely because little fuel exists to sustain large fires (Allard and Leonard, 1946; Platt, 1951; Keener, 1983; Braunschweig and others, 1999). However, fire regimes in nearby pine-oak forests appear, based on dendrochronology, to have been historically important in suppressing later successional species such as Acer saccharum, Fagus grandifolia, and Tsuga canadensis (Abrams and others, 1995). Disturbance from fire within adjacent pine-oak communities possibly played a role in limiting encroachment of woody species onto shale barrens (U.S. Forest Service, 2011). The possible role of fire disturbance in maintaining shale barrens deserves further research so as to inform appropriate management policies (Norris and Sullivan, 2002).

\section{Community Types and Vegetation Dynamics}

Natural Heritage Programs in Virginia, West Virginia, Maryland, and Pennsylvania have all used different sets of names for community classification in shale barrens (Norris and Sullivan, 2002). Although these differing naming conventions were justified in part because of regional variation in community occurrence, they also complicated efforts to assess shale barren habitat throughout its full range. A national classification, developed and standardized by NatureServe and the U.S. National Vegetation Classification, identifies one prairie community and several woodland community types (Fleming and Patterson, 2012), as described next.

\section{Central Appalachian Shale Ridge Prairie}

This community type is ranked G2, with fewer than 25 documented occurrences. This community has been referred to as "shale ridge balds," based on characteristic topographic position along spur ridge crests. In these locations, associations with more stable habitat, higher soil fertility, and dominance of graminoids (such as Schizachyrium scoparium) are distinguishable from shale woodland community types by having a more open physiognomy and "prairie-like" appearance. This community type provides optimal habitat for the endemics Arabis serotina, Clematis viticaulis, Eriogonum allenii, Oenothera argillicola, and Trifolium virginicum.

\section{Chestnut Oak-Virginia Pine/Ragwort Acidic Shale Woodland (Southern Type)}

This community type is ranked G3, with the number of occurrences estimated at several hundred within the State of Virginia alone. This community is located on steep, unstable slopes with canopy coverage ranging from almost closed to mostly open. Shrubs are sparsely distributed, and herbaceous coverage is patchy and typically less than 50 percent.

Thus, this community type can range in physiognomy from scrubby-herbaceous to open stunted woodland. As with other community types, outcroppings of shale bedrock are common, as are unvegetated areas with exposed shale fragments at the soil surface. Compared to other shale woodland community types, species richness and the concentration of shale barren endemic taxa in this community are both high.

\section{North-Central Appalachian Acidic Shale Woodland}

This woodland community type is also ranked G3, with fewer than 100 occurrences estimated rangewide (in Maryland, Pennsylvania, Virginia, and West Virginia). This community typically forms on moderate to steep slopes, 
including convex slopes and ridge spurs. Areas of exposed bedrock may be present, and soils are typically acidic. The canopy ranges from almost closed to mostly open, and is often dominated by Pinus virginiana, Juniperus virginiana, Quercus rubra, and Quercus prinus. The herbaceous layer is typically less than 25 percent and is patchy in distribution along with sparse or scattered shrubs. This community type has a more northerly distribution than some of the other community types and characteristically lacks the species richness - as well as several endemic or near-endemic taxa such as Arabis serotina and Clematis coactilis-found in more southerly community types.

\section{Central Appalachian Virginia Pine/Sparse Herbs Shale Woodland}

This community type is also ranked G3, with a few hundred occurrences in west-central Virginia and eastern West Virginia. This community typically occupies divide crests and strongly convex slopes. Unlike other shale woodland community types, this type typically lacks Juniperus virginiana, is species poor in the herbaceous layer, and has a greater dominance of lichens such as Cladina species. Overall species richness is low, and the canopy is strongly dominated by Pinus virginiana and Quercus prinus. Lack of fire in this community type is believed to contribute to canopy dominance by $P$. virginiana as well as to relatively low herbaceous cover, with edaphic conditions stunting the growth of hardwood successors such as Quercus alba and Q. prinus.

\section{Central Appalachian Chestnut Oak/Mixed Herbs Shale Woodland}

This G3-ranked woodland community commonly borders shale prairies and typically has an open canopy dominated by Quercus prinus. There is a patchy shrub layer, and although herbaceous coverage is generally sparse, there is a relatively high richness of drought-tolerant forbs and graminoids. Soils are typically shallow and acidic. Compared to the Central Appalachian Virginia Pine/Sparse Herbs Shale Woodland, this community type has greater hardwood representation in the canopy and greater herbaceous species richness, differences that might be attributable to edaphic differences or to greater incidence of fire in the past.

Several other related community types also exist within the southeastern United States, including two shale woodland types that are distributed within the Blue Ridge in the Southern Appalachians and a Central Appalachian Circumneutral Barrens community type that may form on calcareous shale or on other substrates such as sandstone.

\section{Contributions to Regional Biodiversity}

Mid-Appalachian shale barrens support a number of plant taxa of conservation concern, including several strict endemics as well as near-endemics that also are present in related contexts, such as outcrops or barrens, on other substrates, or in other regions (table 3-4 in appendix 3). Figure E-5 shows several rare taxa supported by shale barren habitat.

\section{Endemic and Biogeographically Disjunct Taxa}

Braunschweig and others (1999) observed that, although at least seven lists have been published of species endemic to shale barrens, no two lists are in complete agreement and they vary in the number of species included. Several taxa have been renamed, or have undergone taxonomic clarification or recategorization, making the comparison of lists across publications difficult. For example, Frye (1942) mentioned Celtis pumila as a shale barren near-endemic; however, this species is no longer recognized, and its supposed occurrences are now considered to be simply dwarf individuals of Celtis occidentalis (Thomas Wieboldt, Virginia Polytechnic Institute, written commun., 2014). Similarly, Allard (1957) asserted that a shale barren lichen named Cetraria islandica was disjunct from boreal and arctic populations; however, this lichen has been redetermined as Cetraria arenaria, which has a nondisjunct distribution including the Appalachian occurrences (Thomas Wieboldt, Virginia Polytechnic Institute, written commun., 2014).

Some of the ambiguity in itemizing the shale barren endemics is also likely due to the presence of several taxa that have at times been referred to as "strict endemics" but have also been documented on nonshale substrates and in other ecosystems. These include Solidago arguta var. harrisii (found on limestone cliffs and barrens), Trifolium virginicum (on diabase and ultramafic substrates), and Clematis coactilis (on limestone and dolomite) (Braunschweig and others, 1999). Wherry (1953) also described occurrences of some near-endemics on other bedrock types, including sandstone and limestone. Bartgis (1993) noted several shale barren "endemics" in limestone glades in West Virginia. These findings indicate that these taxa might appropriately be labeled near-endemics, and also that they are not highly specialized in terms of their adaption to shale substrate. Indeed, a number of investigators have concluded that many shale barren endemics are geographically restricted less by geologic substrate than by their inability to compete in more shaded, mesic habitats because they are obligate heliophytes (Wherry, 1953; Baskin and Baskin, 1988; Braunschweig and others, 1999; Byers and Norris, 2011).

Of the shale barren endemics, only Arabis serotina is a federally listed endangered species, with possibly fewer 


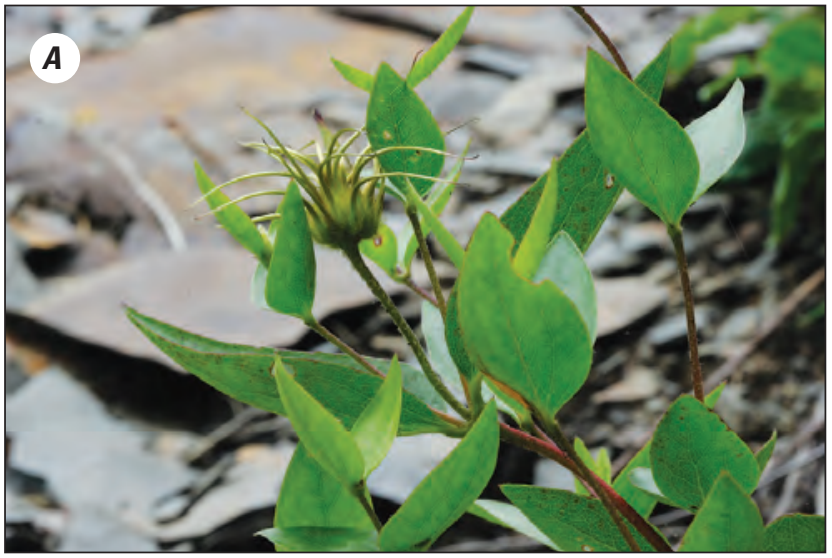

Figure E-5. Characteristic plant taxa of mid-Appalachian shale barrens:

A, Clematis viticaulis, Bath County, Virginia;

$B$, Eriogonum allenii, Woodstock Gap,

George Washington and Jefferson National Forests, Shenandoah County, Virginia;

C, Oenothera argillicola, Alleghany County, Virginia; $D$, Trifolium virginicum, Bath County, Virginia. Photographs $A, C$, and $D$ by Irvine Wilson, Virginia Department of Conservation and Recreation; Photograph $B$ by Gary Fleming, Virginia Department of Conservation and Recreation.
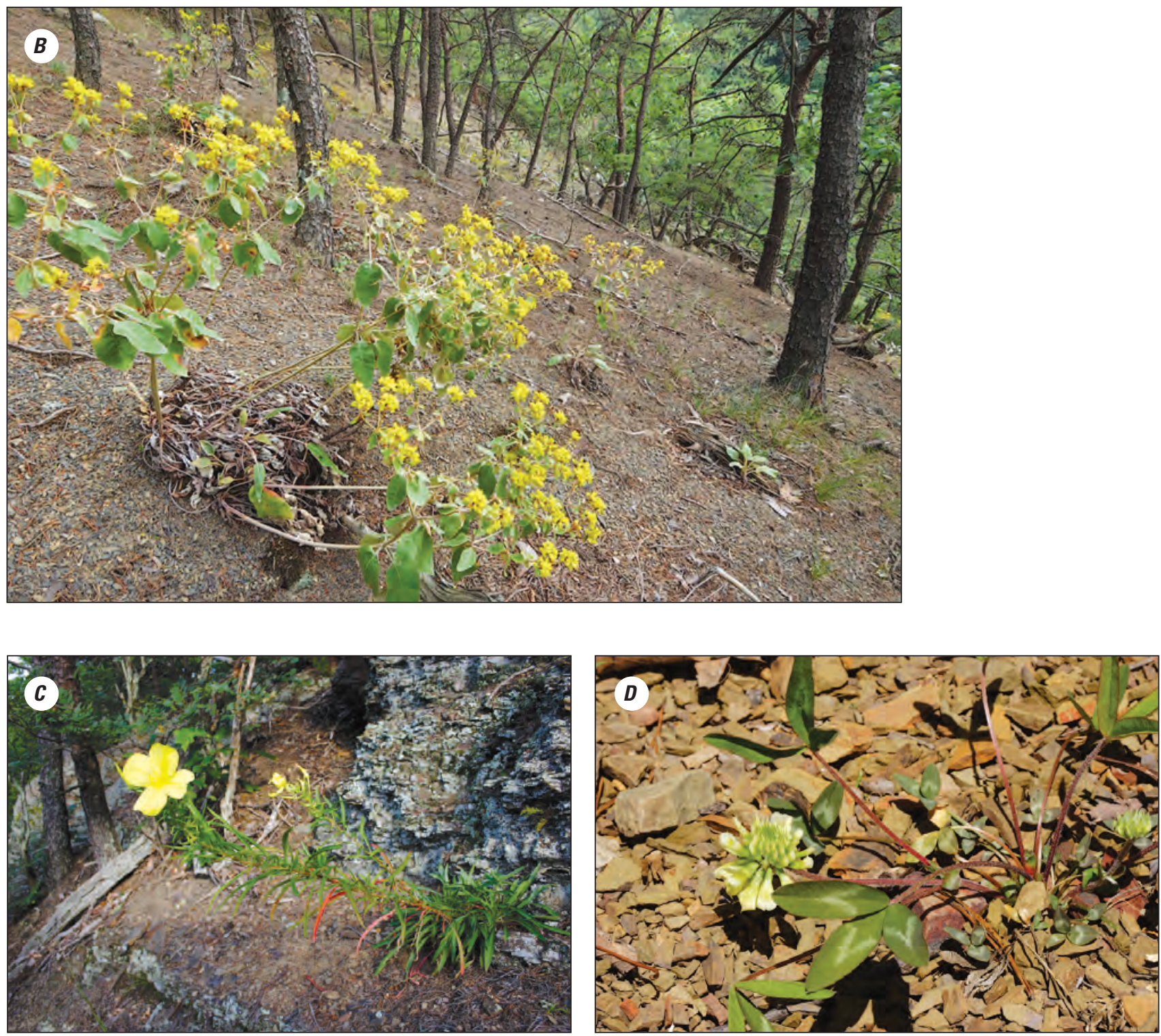
than 4,000 individuals remaining (U.S. Forest Service, 2011). However, several other endemic and near-endemic plant taxa are globally rare, including Clematis coactilis, Oenothera argillicola, Taenidia montana, and Trifolium virginicum (all ranked G3); Allium oxyphilum and Phlox buckleyi (G2); and Clematis viticaulis (G1).

Many shale barren endemics and near-endemics share common characteristics believed to represent adaptations to the stress regime of their habitat. For example, adaptations to drought stress may provide a competitive advantage to some shale barren plants in an environment where surface soil moisture is limited but water is available lower in the soil profile. Certain species, particularly geophytes and hemicryptophytes, are dependent primarily on the $\mathrm{C}$ horizon for moisture and nutrients and can thus better tolerate low water availability at upper soil horizons (Platt, 1951; Braun, 1955). Not surprisingly, many of these species possess unusually high root-to-shoot ratios (Platt, 1951; Keener, 1983; Norris and Sullivan, 2002).

In addition, some adaptations appear to aid in germination and recruitment under conditions of harsh abiotic stress. Some shale barren species time their life cycles to the seasonal availability of soil moisture, such that plants are dormant or engaged in seed maturation during the driest times of the year (Platt, 1951). Also, experiments have shown the seeds, seedlings, and leaves of some endemics to have relatively high tolerance for heat. Platt (1951) found bud mortality for several shale barren plants to occur between 42 and $45^{\circ} \mathrm{C}$. Braunschweig (1993) found membrane thermotolerance for the mature leaves of the shale barren endemic Eriogonum allenii to be up to $52^{\circ} \mathrm{C}$. Tolerance for high-heat and highlight conditions is facilitated in some cases by morphological adaptations such as waxy leaf coatings and steep leaf angles to minimize light interception (Nilsen and Orcutt, 1996). Additionally, some shale barren taxa have been shown to have considerable intraspecific variation and genetic diversity (Platt, 1951; Baskin and Baskin, 1988). Bayer and Crawford (1986), for example, reported genetic diversity for the shale barren endemic Antennaria virginica that was comparable to that of its more geographically widespread congeners.

Biogeographic disjunction has also been noted for some plant taxa found in shale barrens. Several generations of shale barren explorers have noted an affinity between certain shale barren plants and western taxa, highlighted by disjunct populations of western species growing on shale barrens (Frye, 1942; Braun, 1955; Keener, 1983; Braunschweig and others, 1999). E. allenii and Packera antennariifolia are members of widespread genera, with closest relatives that are typically associated with the Rocky Mountains (Core, 1932; Artz, 1948; Braun, 1955; Noss, 2013). Core (1932, 1952) described the Appalachian presence of Astragalus distortus as being disjunct from its primary range in the Midwest prairies. Knobloch and Lellinger (1969) described occurrences of Cheilanthes eatonii on Virginia and West Virginia shale barrens, whereas the central distribution of this species is in the southwestern United States and Mexico. Some disjunctions occur with large distances of complete separation: approximately 1,200 miles (about 2,000 kilometers) in the case of Asplenium septentrionale, which ranges from Oregon to Texas with the exception of disjunct occurrences in West Virginia on shale barrens. A few other disjunct taxa have populations geographically intermediate between their western ranges and the Appalachian shale barren populations (Braunschweig and others, 1999).

\section{Animal Taxa of Conservation Concern}

Relatively little research has been done on the fauna of shale barrens, including the interactions between shale barren plants and insects, such as herbivory or pollination (Wheeler, 1995). Some evidence does suggest that shale barrens offer habitat to rare arthropod taxa. Two rare butterfly species are associated with shale barren habitat: Pyrgus wyandot (Appalachian grizzled skipper) and Euchloe olympia (Olympia marble) (Braunschweig and others, 1999). P. wyandot is ranked G1 and has been extirpated across much of its original range in the United States, whereas E. olympia has secure populations throughout the Midwest, Rocky Mountains, and in Canada but is State-rare in the Appalachian region. Several rare spider species, including one previously undescribed species (Hahniidae), another possible new species (Araniidae), and four species previously unrecorded in West Virginia, were collected by the West Virginia Natural Heritage Program in a pit trap survey at one shale barren site (Norris and Sullivan, 2002). Chinaola quercicola, a microphysid insect with specialized habitat on granite outcrops and pitch pine-scrub oak barrens, has also been found in a shale barren (Wheeler, 1992). Some evidence suggests that shale barrens may be ecologically important to certain insects by providing specialized habitat or access to resources. For example, Kalhorn and others (2003) reported greater activity of bees on shale barren interiors than in the surrounding forest or ecotone. In a survey of plant bugs (Heteroptera: Miridae), Wheeler (1995) noted that certain species showed a distinct affinity to midAppalachian shale barrens.

\section{Conservation Considerations}

Mid-Appalachian shale barrens have been recognized as important conservation priorities, primarily because of their contributions to regional plant biodiversity (Braunschweig and others, 1999; Norris and Sullivan, 2002). A number of threats and conservation options have been identified. Gaps in scientific knowledge have been highlighted, indicating needs for additional research in this ecosystem.

\section{Threats to Ecosystem Integrity}

Mid-Appalachian shale barrens may be more protected from anthropogenic destruction than some other types of 
natural forest openings because of their lack of commercial value and because their steep slopes and scree make them treacherous to hikers and unattractive sites for development (Braunschweig and others, 1999; Norris and Sullivan, 2002). Trampling from recreational use may still be a problem in some cases, however, and some shale barrens have been damaged by the construction of hiking trails (U.S. Forest Service, 2011). A few shale barrens have been degraded or destroyed by road construction (Braunschweig and others, 1999; Norris and Sullivan, 2002), and shale barrens near roads have also been damaged by quarrying for road material (Platt, 1951; Norris and Sullivan, 2002). Shale barren sites located downslope from developed areas have also been subjected to trash dumping (Norris and Sullivan, 2002; U.S. Forest Service, 2011). Although shale barrens typically do not produce adequate timber to attract large-scale logging operations, certain sites have been affected by the cutting of trees for fenceposts (Braunschweig and others, 1999; Norris and Sullivan, 2002). A few shale barrens with low slope near pastures have been grazed by livestock (Platt, 1951). At least one shale barren has been destroyed by flooding from an upstream impoundment (Dix, 1990; U.S. Forest Service, 2011).

The application of pesticides may be a threat to the rare flora and fauna of some shale barrens, which are maximally exposed to aerial spraying due to their relatively open canopies. The regional use of insecticides to control Lymantria dispar (gypsy moth) has inadvertently affected rare lepidoptera such as the Appalachian grizzled skipper in shale barrens (Norris and Sullivan, 2002). Dimilin is a broad-spectrum insecticide that can persist for up to several years in leaf litter and may pose a lasting threat in shale barrens. Bacillus thuringiensis (Bt), a biological pesticide, persists for only a week or so but can be a threat to shale barren lepidoptera if applied during larval development (Dix, 1990). These pesticides may also threaten the globally rare shale barren endemic Arabis serotina by harming its insect pollinators, which include the Appalachian grizzled skipper (Dix, 1990; U.S. Forest Service, 2011). Lack of cross-pollination in A. serotina is likely to result in inbreeding depression and a corresponding reduction in germination; thus, attempts to conserve A. serotina populations must necessarily incorporate steps to conserve the Appalachian grizzled skipper and other rare pollinators in shale barrens (Nott, 2006).

Shale barren endemics such as A. serotina may also be threatened by browsing from native herbivores, primarily deer (Nott, 2006), because several A. serotina populations show evidence of moderate to severe damage from deer browsing (U.S. Forest Service, 2011). Although the stress regime of shale barrens may offer some protection against invasion by exotic species, grazing by sheep and goats and recreational use can introduce exotic weedy plants that may pose a threat to certain endemics (Braunschweig and others, 1999; Keech, 1999; Nott, 2006). Some invasive species can be allelopathic to native taxa and distasteful to native herbivores (Nott, 2006).
The presence of exotics, including Centaurea biebersteinii, Bromus sterilis, and B. japonicus, has been noted and mentioned as a possible threat to A. serotina, which is a poor competitor (Dix, 1990; Norris and Sullivan, 2002; U.S. Forest Service, 2011).

\section{Conservation Strategies}

Shale barrens are present on protected public land in three national forests: George Washington and Jefferson National Forests in Virginia and Monongahela National Forest in West Virginia (DeSelm and Murdock, 1993; Norris and Sullivan, 2002). A few other shale barren sites are present on land owned by the U.S. Army Corps of Engineers and The Nature Conservancy (Norris and Sullivan, 2002). The great majority of mid-Appalachian shale barrens (possibly up to 80 percent) are believed to be on privately owned, nonprotected land (Norris and Sullivan, 2002), however, no comprehensive map of the location of shale barrens exists. Even on protected land, active management of shale barrens is sporadic and is generally limited to the removal or attempted control of exotic species (Norris and Sullivan, 2002). Some past and current monitoring efforts have focused on rare plants (especially Arabis serotina and Eriogonum allenii) and lepidoptera; however, the methods and intensity of monitoring activities vary between managing agencies.

\section{Knowledge Gaps}

Norris and Sullivan (2002) stated that "despite a plethora of shale barren literature, there has been far more speculation than substantial ecological research and observation." Very little is known about pollination or dispersal strategies of shale barren endemics (Braunschweig and others, 1999), and as a result, virtually nothing is known about how endemics disperse between shale barrens (Norris and Sullivan, 2002). Also, few publications have described shale barren species other than vascular plants. Ammons (1943) presented a list of 21 mosses and 2 liverworts observed on a single trip to a single shale barren; however, he noted that many of these bryophyte species were not necessarily confined to shale barren habitat. The ecology, physiology, and biogeography of lichens and bryophytes in mid-Appalachian shale barrens deserve further study because they appear to be important constituents of several shale barren communities. Shale barrens have also received limited attention from entomologists, despite the discovery of rare and disjunct lepidoptera that use shale barren endemic plants as larval hosts (Norris and Sullivan, 2002). Although some information is available on the interspecific interactions of the more well-studied shale barren plants such as Arabis serotina (Nott, 2006), many of the trophic interactions and food-web dynamics in shale barrens have yet to be examined empirically. 


\section{Possible Ecological Effects from Climate Change}

Although harsh microclimatic conditions are frequently described in the literature concerning mid-Appalachian shale barrens, little research has been done on their vulnerability to climate change. Recent reviewers of this ecosystem, such as Braunschweig and others (1999) and Norris and Sullivan (2002), discussed a number of anthropogenic threats to shale barrens but did not explicitly discuss climate change. Byers and Norris (2011) assessed the climate-change vulnerability of several West Virginia species and determined that Arabis serotina and Trifolium virginicum would be highly vulnerable, Phlox buckleyi would be moderately vulnerable, and Pyrgus wyandot was presumed stable; however, the confidence associated with these predictions was categorized as "low" for A. serotina and T. virginicum. Furthermore, these assessments were for individual species, and Byers and Norris (2011) did not include an ecosystem-level vulnerability assessment nor a detailed explanation of the mechanisms by which climate change might threaten each species. For example, increased vulnerability for $A$. serotina was attributed to factors named "dispersal/movement," "historical hydrological niche," "disturbance," "physical habitat," and "genetic bottlenecks," but Byers and Norris (2011) did not explain the physical or biological mechanisms by which climate change would interact with these factors to increase vulnerability.

Certain climate-related stress factors in mid-Appalachian shale barrens - specifically seasonally high temperatures and seasonal moisture limitation at the soil surface - are often credited with the exclusion of mesic competitors and the maintenance of ecosystem integrity, including habitat for endemic taxa (Platt, 1951; Keener, 1983; Braunschweig and others, 1999; Norris and Sullivan, 2002; Nott, 2006). Higher temperatures at a regional level would presumably elevate soil surface temperatures in shale barrens on a seasonal basis. Some experimental evidence suggests that certain plant taxa adapted to heat stress in shale barren habitat are already near their heat-tolerance thresholds when subjected to the hottest and driest conditions in mid to late summer (Platt, 1951; Braunschweig, 1993). Thus, further elevation in seasonally high soil surface temperatures might surpass even the capacities of these specially adapted taxa to cope with heat stress. An evaluation of the likelihood of this scenario would require better identification of the heat-tolerance thresholds of shale barren taxa coupled with specific predictions of temperature change at the soil surface.

Hydrologic change would presumably be another avenue by which climate change might affect mid-Appalachian shale barren ecosystems. As part of a species-level climate vulnerability assessment in West Virginia, Byers and Norris (2011) predicted that "all habitats are likely to face increased drought stress, especially during the summer and early fall." Given that temperature increases have a disproportionate effect on evaporative drying in shale barren habitat relative to surrounding forests (Platt, 1951), increased seasonal drought stress in shale barrens appears to be a likely consequence of regional climate change. This increased stress might help maintain shale barrens by slowing the encroachment of mesic plant species and boosting the competitive advantage of drought-adapted endemic taxa. However, the droughttolerance thresholds of most shale barren taxa have not been systematically identified, and it is unclear if exacerbated seasonal dryness might stress these taxa beyond their coping abilities. Existing knowledge of the physiology and life cycles of some shale barren taxa does suggest that the timing of precipitation will continue to be important because some plants time their reproduction to minimize the drought stress experienced during the vulnerable germination period (Platt, 1951). Also, because some shale barren taxa are adapted to exploit moisture within the $\mathrm{C}$ horizon of soil (Platt, 1951; Keener, 1983), hydrologic changes affecting moisture availability at this depth might have more relevance to these taxa than would those changes limited to the soil surface. Other possible climate-change effects on mid-Appalachian shale barrens that could be biologically mediated are even more difficult to predict. The possible interactive effects of stress regime alteration coupled with climate-driven changes in biotic processes - such as exotic species invasions, herbivory, and pollination - are largely unknown.

\section{References}

Abrams, M., Orwig, D., and Demeo, T., 1995, Dendroecological analysis of successional dynamics for a presettlement-origin white-pine-mixed-oak forest in the southern Appalachians, USA: Journal of Ecology, v. 83, p. 123-133.

Allard, H., 1957, Occurrence of the lichen Cetraria islandica Ach. in Virginia and West Virginia: Castanea, v. 22, no. 2, p. 106-109.

Allard, H., and Leonard, E., 1946, Shale barren associations on Massanutten Mountain, Virginia: Castanea, v. 11, no. 3, p. $71-124$.

Ammons, N., 1943, Bryophytes of the Appalachian shale barrens: Castanea, v. 8, no. 7/8, p. 128-131.

Artz, L., 1937, Plants of the shale banks of the Massanutten Mountains of Virginia: Claytonia, v. 3, p. 45-50.

Artz, L., 1948, Plants of the shale barrens of the tributaries of the James River in Virginia: Castanea, v. 13, no. 4, p. $141-145$.

Bartgis, R., 1993, The limestone glades and barrens of West Virginia: Castanea, v. 58, no. 2, p. 69-89. 
Baskin, J., and Baskin, C., 1988, Endemism in rock outcrop plant communities of unglaciated eastern United StatesAn evaluation of the roles of the edaphic, genetic and light factors: Journal of Biogeography, v. 15, no. 5, p. 829-840.

Bayer, R., and Crawford, D., 1986, Allozyme divergence among five diploid species of Antennaria (Asteraceae: Inuleae) and their allopolyploid derivatives: American Journal of Botany, v. 73, no. 2, p. 287-296.

Braun, E., 1955, The phytogeography of unglaciated eastern United States and its interpretation: The Botanical Review, v. 21 , no. 6 , p. 297-375.

Braunschweig, S., 1993, The acclimation ability of the shale barren endemic Erigonum allenii to light and heat: Blacksburg, Va., Virginia Polytechnic Institute and State University, Ph.D. Dissertation.

Braunschweig, S., Nilson, E., and Wieboldt, T., 1999, The mid-Appalachian shale barrens, in Anderson, R., Fralish, J., and Baskin, J.M., eds., Savannas, barrens, and rock outcrop plant communities of North America: New York, Cambridge University Press, p. 83-98.

Byers, E., and Norris, S., 2011, Climate change vulnerability assessment of species of concern in West Virginia: Elkins, W.Va., West Virginia Divison of Natural Resources.

Clarkson, R., 1966, The vascular flora of the Monongahela national forest, West Virginia: Castanea, v. 31, no. 1, p. $1-119$.

Core, E., 1932, Some aspects of the phytogeography of West Virginia: Torreya, v. 32, no. 3, p. 65-71.

Core, E., 1952, The ranges of some plants of the Appalachian shale barrens: Castanea, v. 17, no. 3, p. 105-116.

DeSelm, H., and Murdock, N., 1993, Grass-dominated communities, in Martin, W., Boyce, S., and Echternacht, A., eds., Biodiversity of the southeastern United StatesUpland terrestrial communities: New York, John Wiley and Sons, Inc., p. 87-141.

Dix, E., 1990, Element stewardship abstract for Appalachian shale barrens: Arlington, Va., The Nature Conservancy.

Fenneman, N., 1938, Physiography of the Eastern United States: New York, McGraw-Hill.

Fenneman, N., and Johnson, D., 1946, Physical divisions of the United States: U.S. Geological Survey map prepared in cooperation with the Physiographic Commission, scale $1: 7,000,000$.
Fleming, G., and Patterson, K., 2012, Natural communities of Virginia-Ecological groups and community types: Richmond, Va., Virginia Department of Conservation and Recreation, Division of Natural Heritage.

Frye, W., 1942, Notes on the flora of the South Branch Valley: Castanea, v. 7, no. 8, p. 118-122.

Heikens, A., West, K., and Robertson, P., 1994, Short-term response of chert and shale barrens vegetation to fire in southwestern Illinois: Castanea, v. 59, no. 3, p. 274-285.

Kalhorn, K., Barrows, E., and LaBerge, W., 2003, Bee (Hymenoptera: Apoidea: Apiformes) diversity in an Appalachian shale barrens: Journal of the Kansas Entomological Society, v. 76, no. 3, p. 455-468.

Keech, D., 1999, Managing invasive weeds on shale barrens: Chevy Chase, Md., The Nature Conservancy.

Keener, C., 1983, Distribution and biohistory of the endemic flora of the mid-Appalachian shale barrens: The Botanical Review, v. 49, no. 1, p. 65-115.

Knobloch, I., and Lellinger, D., 1969, Cheilanthes castanea and its allies in Virginia and West Virginia: Castanea, v. 34, no. 1, p. 59-61.

McCall, R., and Gibson, D., 1999, The regeneration potential of a threatened southern Illinois shale barren: Journal of the Torrey Botanical Society, v. 126, no. 3, p. 226-233.

Morse, L., 1983, A shale barren on Silurian strata in Maryland: Castanea, v. 48, no. 3, p. 206-208.

NatureServe, 2015, NatureServe Explorer-An online encyclopedia of life [web application], ver. 7.1, accessed October 7, 2015, at http://www.natureserve.org/explorer.

Nilsen, E., and Orcutt, D., 1996, The physiology of plants under stress: New York, John Wiley.

Norris, S., and Sullivan, R., 2002, Conservation assessment for the mid-Appalachian shale barrens: Elkins, W. Va., West Virginia Divison of Natural Resources.

Noss, R., 2013, Forgotten grasslands of the south: Washington, D.C., Island Press.

Nott, M., 2006, Shale barren rock cress (Arabis serotina)A literature review and analysis of vegetation data: Sugar Grove, W.V., Navy Information and Operations Command and the Institute for Bird Populations.

Platt, R., 1951, An ecological study of the mid-Appalachian shale barrens and of the plants endemic to them: Ecological Monographs, v. 21, no. 4, p. 269-300. 
Rawinski, T., Hickmain, K., Waller-Elling, J., Fleming, G., Austin, C., Helmick, S., Huber, C., Kappesser, G., Huber, F., Bailey, T., and Collins, T., 1996, Plant communities and ecological land units of the Glenwood Ranger District, George Washington and Jefferson National Forests:

Richmond, Va., Virginia Department of Conservation and Recreation.

U.S. Geological Survey, National Gap Analysis Program, 2011, Land cover data portal, accessed December 2015 at http://gapanalysis.usgs.gov/gaplandcover/data/download/.

U.S. Forest Service, 2011, Draft environmental impact statement for the revised land and resource management plan, George Washington National Forest: Roanoake, Va., U.S. Department of Agriculture, Forest Service.
West, N.M., Gibson, D.J., and Minchin, P.R., 2009, Characterizing the microhabitats of exotic species in Illinois shale barrens: Plant Ecology, v. 200, no. 2, p. 255-265.

Wheeler, A., 1992, Chinaola quercicola rediscovered in several specialized plant communities in the southeastern United States (Heteroptera: Microphysidae): Proceedings of the Entomological Society of Washington, v. 94, no. 2, p. $249-252$.

Wheeler, A., 1995, Plant bugs (Heteroptera: Miridae) of Phlox subulata and other narrow-leaved phloxes in eastern United States: Proceedings of the Entomological Society of Washington, v. 97, p. 435-451.

Wherry, E., 1953, Shale-barren plants on other geological formations: Castanea, v. 18, no. 2, p. 64-65. 


\section{Chapter F. High-Elevation Outcrops and Balds of the Southern Appalachians}

\section{Introduction}

The summits of even the highest peaks of the southern Appalachian Mountains are forested - estimates of a theoretical treeline based on current climate suggest it would be about 1,300 feet (approximately 400 meters) above the highest peaks in the region-yet a number of treeless openings exist within the generally forested landscape (Gersmehl, 1973; Cogbill and others, 1997; White and Sutter, 1999). These high-elevation forest openings, above 4,000 feet (about 1,200 meters), include grass and heath balds (fig. F-1) and high-elevation rock outcrops (Wiser and White, 1999). Grass balds are high-elevation communities dominated by grasses and sedges, with a sub-dominant component of forbs, shrubs, and scattered trees. Grass balds vary in size, from roughly 2 to 20 acres (about 1 to 8 hectares) in Great Smoky Mountains National
Park to more than 500 acres (more than 200 hectares) on Roan Mountain in eastern Tennessee (White and Sutter, 1999). Heath balds are high-elevation communities dominated by shrubs, typically by ericaceous, acid-tolerant species from genera including Rhododendron, Kalmia, and Vaccinium (Pittillo and others, 1998), and in some cases also including Photinia melanocarpa, Viburnum nudum var. cassinoides, Clethra acuminata, and Gaylussacia baccata (Whittaker, 1963). At elevations above 4,000 feet (about 1,200 meters), high-elevation rock outcrop communities are forest openings characterized by exposed bedrock with sparse vegetation, a preponderance of lichens, mosses, and low-growing forbs, and characteristic assemblages of endemic species (Wiser and others, 1996; Wiser and White, 1999; Schafale, 2012).

As a set of ecosystems, high-elevation outcrops and balds of the southern Appalachians are all rare, resulting in their

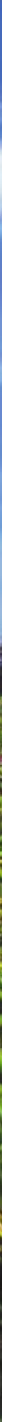


being ranked G1 to G3. Grass and heath balds are categorized together under the Southern Appalachian Grass and Shrub Bald Ecological System based on the International Terrestrial Ecological Systems Classification (ITESC) used by NatureServe (2015), with this ecological system containing several natural communities that are grass bald types (all ranked G1) and several heath-bald types (ranked G2 or G1) (Fleming and Patterson, 2012; Schafale, 2012). The natural communities corresponding to high-elevation rock outcrops are ranked G1, G2, or G3 (Schafale, 2012).

\section{Geographic Range}

High-elevation outcrops and balds are present in the Blue Ridge Physiographic Province (Fenneman and Johnson, 1946) throughout the southern Appalachian region (fig. F-2). The southern Appalachian region includes the Blue Ridge Mountains, the Unaka Mountains, and the system of basins and traverse mountain chains (including the Black Mountains and the Great Craggy Mountains) that extend between them, covering about 10,000 square miles (about 26,000 square kilometers) in southern Virginia, western North Carolina, eastern Tennessee, and northern Georgia (Mark, 1958; Ramseur, 1960). Grass balds are present in parts of Virginia, North Carolina, and eastern Tennessee, but their distribution is believed to be clustered primarily within Great Smoky Mountains National Park and on Roan Mountain (White and Sutter, 1999). Within Virginia, the geographic extent of grass balds is extremely limited and is restricted primarily to an area near the summit of Whitetop Mountain (Fleming and Patterson, 2012). Similar grass balds also are present in the central Appalachian region of West Virginia and Virginia, and although they share many similarities to southern Appalachian grass balds in terms of climate, disturbance history, and soil characteristics, they are floristically different. For example, the balds of West Virginia studied by Rentch and Fortney (1997) had a more diverse herbaceous layer and a more highly developed shrub component than those in the southern Appalachians.

Like grass balds, heath balds are also patchily distributed throughout the southern Appalachian region, with most occurrences in Tennessee and North Carolina. In Virginia, heath balds are confined to only a few sites in the Mount

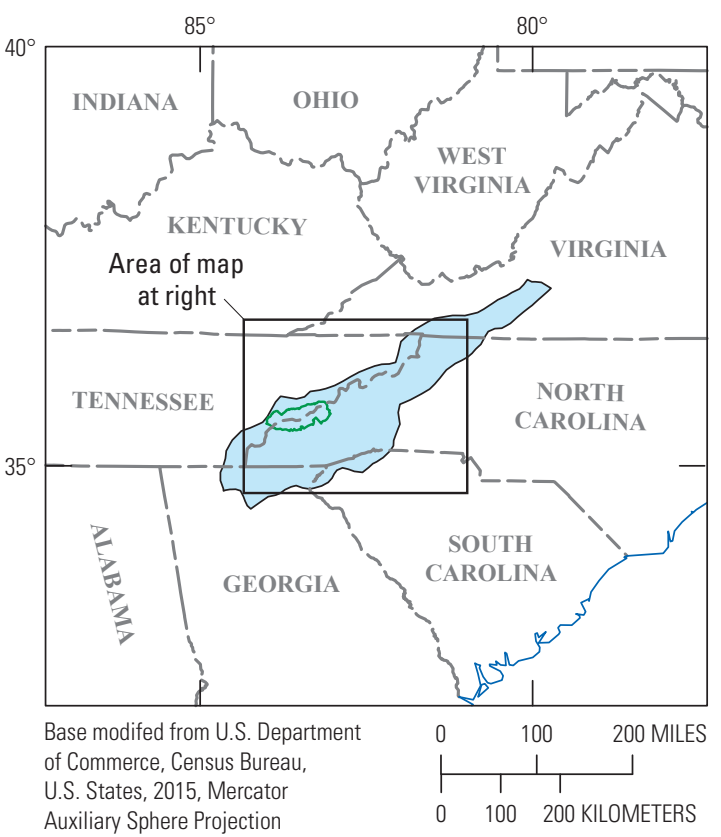

Figure F-2. Geographic distribution of high-elevation outcrops and balds in the southern Appalachians.

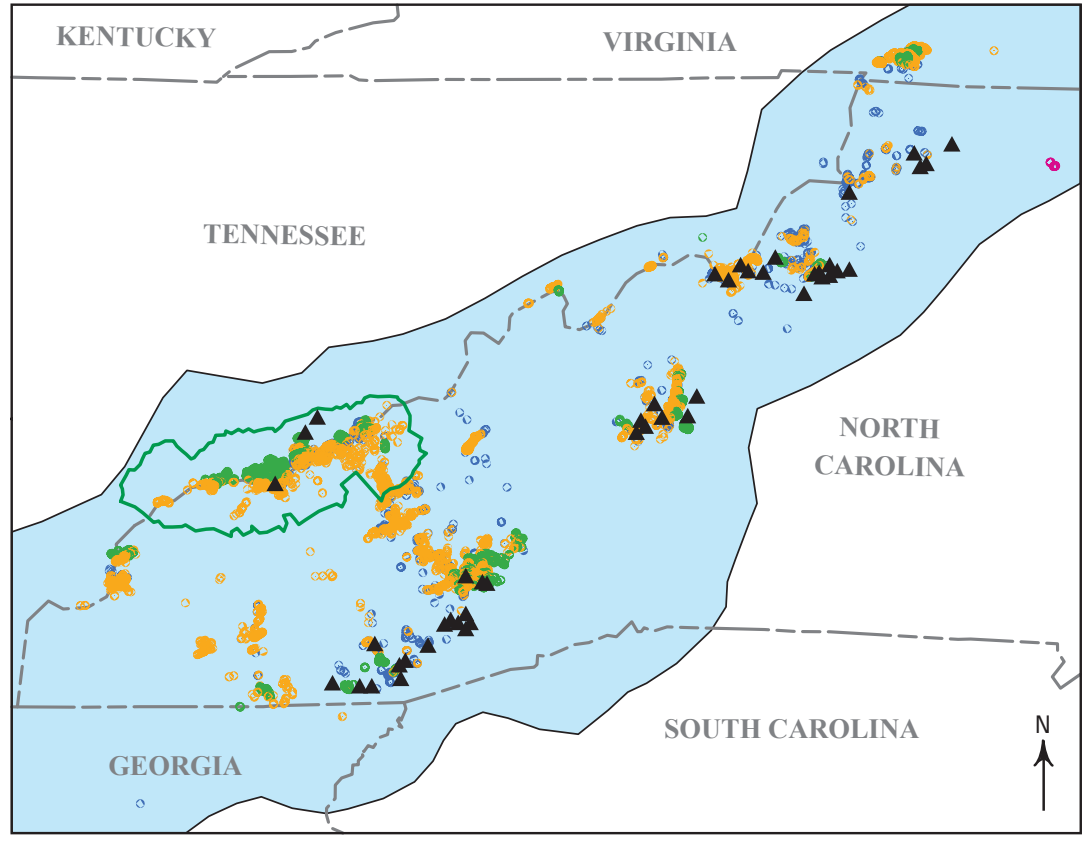

EXPLANATION

Blue Ridge Physiographic ProvinceFrom Fenneman and Johnson (1946)

Great Smoky Mountains National Park

- Selected occurrences of high-elevation rock outcrops-Based on locations sampled by Wiser (1994)
Ecological System-Modified from U.S. Geological Survey (2011)

- Southern Appalachian Grass and Shrub Bald (Herbaceaous)

- Southern Appalachian Grass and Shrub Bald (Shrub)

- Southern Appalachian Granitic Dome

- Southern Appalachian Rocky Summit 
Rogers-Whitetop Mountain area and in the Iron Mountains (Fleming and Patterson, 2012). Within Great Smoky Mountains National Park, heath balds are distributed primarily in the northern and eastern regions of the park (White and others, 2001). Heath balds have also been documented in the Great Craggy Mountains (Thomas and Pittillo, 1987) and in the Amphibolite Mountains (Lee, 2004) of North Carolina and on Roan Mountain in eastern Tennessee, among other locations.

Generally, rock outcrops above 4,000 feet (about 1,200 meters) are geographically restricted to the southern Appalachians south of the southern border of Virginia (Wiser and others, 1996). Within this zone of high-elevation rock outcrop distribution, physical habitat conditions show geographic variablility. For example, mafic parent material is more common in the northern part of the area (north of Grandfather Mountain) and generally weathers to form more fertile soil with higher magnesium and iron concentrations than does the felsic parent material more common in the southern part of the area (Wiser and others, 1996).

\section{Physical Geography}

Grass balds are present at elevations ranging from approximately 4,600 to 6,200 feet (about 1,400 to 1,900 meters), with the majority between 5,200 to 5,800 feet (about 1,600 to 1,780 meters); heath balds are present from roughly 3,900 to 6,500 feet (about 1,200 to 2,000 meters) (Mark, 1958). Grass and heath balds generally have southern to western aspects (Whittaker, 1956). Grass balds form on rounded ridgetops, domes, gaps, and southern slopes, which range from nearly level to about $15^{\circ}$ and in some places greater than $25^{\circ}$ in slope and are commonly located along the elevational ecotone between hardwood forest below and spruce-fir (Picea rubens and Abies fraseri) forest above (Wells, 1936b; Billings and Mark, 1957; Mark, 1958). Heath balds are generally confined to exposed ridgetops and steep slopes (Jenkins, 2007).

High-elevation rock outcrops and balds typically develop on parent material of Precambrian origin, which can be igneous (felsic or mafic), sedimentary, or metamorphic, on substrates including granite, gneiss, schist, gabbro, amphibolite, sandstone, sand conglomerates, and quartzites (Cain, 1931; Wiser and others, 1996). High-elevation rock outcrop soils are generally classified as Entisols or Lithic Haplumbrepts, with relatively high organic matter content and thickness of typically less than 12 inches (about 30 centimeters) (Wiser and others, 1996; Wiser and White, 1999). Soils are generally acidic, with pH ranging from below 3.5 to circumneutral (Wiser, 1993). Soil $\mathrm{pH}$, nutrient levels, and water-holding capacity in these outcrops can be related to factors including bedrock type, topographic position, and the presence or absence of seepage (Wiser and others, 1996; Wiser and White, 1999).
In general, the soil of grass balds is considered to be similar to that of the surrounding forest soil (Wiser and White, 1999); however, individual studies comparing the two have produced somewhat mixed results. Mark (1958) reported $\mathrm{pH}$ values ranging from 3.5 to 5.0 for several grass balds, with similar values for surrounding forest soils. Organic matter ranged from 8.1 percent to 28.6 percent in the $\mathrm{A} 1$ horizon for grass balds and from 15.1 percent to 70.8 percent for surrounding forest. Chemical analysis of soil from grass balds and surrounding forest indicated that both soils are highly leached (Mark, 1958). Comparing sites in the Great Smoky Mountains, McCracken and others (1962) found that soil from a grass bald was largely similar in morphology and chemistry to soil from spruce-fir and beech gap sites, but the grass bald soil had higher $\mathrm{pH}$, lower exchangeable aluminum and free iron, and wider carbon:nitrogen ratios.

Heath bald soils have been classified as podzols (McCracken and others, 1962) and as folist histosols (Conkle and others, 2003). These soils may be covered with peat deposits ranging from thin crusts to several inches in thickness and are often covered with a layer of Sphagnum and associated mosses where sufficient moisture exists (Cain, 1931). Relative to grass balds, heath bald soils are highly acidic and highly organic (Cain, 1931; McCracken and others, 1962; Whittaker, 1963). For example, heath bald soils studied by Conkle and others (2003) had organic matter content greater than 80 percent, had $\mathrm{pH}$ below 3.0, and had high aluminum saturation and high cation exchange capacity.

The combination of extreme acidity and generally low levels of calcium and potassium in heath bald soils suggests excessive leaching (McCracken and others, 1962; Whittaker, 1963), a property that may be attributable in part to topographic position. Precipitation is abundant at these high elevations but is drained quickly through the subsurface and down the steep slopes (Whittaker, 1956). Heath balds commonly occupy ridgetops, which have been associated with acidic soil. For example, Cain (1931) demonstrated a pH correlation with topography in the Great Smoky Mountains, with ridgetops having the lowest $\mathrm{pH}(2.9-3.7)$, valleys having the highest $\mathrm{pH}(3.7-5.1)$, and intervening slopes having intermediate values, a correlation he attributed to increased leaching with elevation. Other factors that likely contribute to the acidity of heath bald soils include microclimatic conditions (high moisture, low temperatures, and poor aeration) promoting the formation of peat, as well as the decomposition of ericad and conifer leaves and the influence of Sphagnum and related mosses, which are known to decrease the $\mathrm{pH}$ of soils in which they grow (Cain, 1931).

Throughout the southern Appalachians, precipitation gradients generally increase from northeast to southwest (Mark, 1958; Wiser and others, 1996). Regionally, precipitation derives from winter cyclones, summer and autumn hurricanes, and summer thunderstorms, such that rainfall 
is reasonably well distributed throughout the year with a slight increase during the summer and early autumn (Mark, 1958). Soil moisture availability typically increases with elevation because of increased precipitation and because lower temperatures at higher elevations result in lower rates of evapotranspiration (Mark, 1958). At the highest elevations in the Appalachians - generally those supporting spruce-fir forest, above the elevational ecotone with deciduous forest - cloud immersion is an important part of ecosystem dynamics, occurring on approximately 2 out of every 3 days and contributing approximately 45 percent of the annual water input (Johnson and Smith, 2008). Cloud immersion affects the hydrologic cycle of montane ecosystems not only through direct water inputs but also indirectly through effects on temperature, relative humidity, and evapotranspiration (Foster, 2001). Cloud immersion also alters solar irradiance, diffusion, and spectral quality of sunlight. These effects are not constant across ecosystems; whereas cloud cover decreases irradiance in open areas, it enables greater penetration of light into forest understories (Johnson and Smith, 2008). Leaf wetness resulting from cloud immersion can also have a range of consequences for photosynthetic activity and carbon assimilation (Johnson and Smith, 2008). Fog is another important environmental factor for these high-elevation ecosystems, with effects similar to those of cloud immersion: increased humidity, diffusion of solar irradiation, reduced evapotranspiration, and - in winter - possible formation of rime ice (Mark, 1958).

The unique water regime of high-elevation balds and rock outcrops distinguishes them in part from their counterparts at lower elevations. For example, high-elevation rock outcrops generally have greater (and less seasonally variable) water availability than outcrops at lower elevations due to increased precipitation, cooler temperatures, and cloud or fog immersion (Schafale and Weakley, 1990; Wiser, 1994). Moisture availability from seepage is also a component of the water regime in many high-elevation rock outcrops; however, moisture availability is highly variable even at small spatial scales and can range from continuous to only sporadic (Schafale and Weakley, 1990). Sites perennially wet from seepage have considerably different soil chemistry than dry sites, including higher $\mathrm{pH}$, sodium, and water-holding capacity (Wiser and White, 1999).

\section{Stress and Disturbance Regimes}

High-elevation outcrops, grass balds, and heath balds generally share certain environmental conditions, including high irradiation, dessicating winds, high rainfall, frequent fog, and an important fraction of water input from cloud immersion (Crawford, 2007; Johnson and Smith, 2008). Frost typically occurs between late September and mid-May, and wind speeds in winter can exceed 20 miles per hour (about 30 kilometers per hour) (Wiser and others, 1996). Whittaker
(1956) published a schematic diagram of vegetation communities in the Great Smoky Mountains based on elevation and topographic position and situated grass balds and heath balds in one extreme corner - the highest elevations and most exposed and xeric topographic sites. The extent to which abiotic stress factors contribute to ecosystem maintenance is unclear, however. Furthermore, any discussion of the stress or disturbance regimes that currently maintain grass and heath balds invariably raises the question of their origins, a subject that has been controversial for decades (Lindsay and Bratton, 1979b; Wiser and White, 1999; Crawford and Kennedy, 2009).

Both types of balds occupy only a small fraction of seemingly appropriate sites within their ranges based on topographic and environmental factors (White and Sutter, 1999; White and others, 2001). Grass balds appear not to be edaphically determined or constrained, and their soil is generally comparable to that of the surrounding forest (Mark, 1958; Wiser and White, 1999). Isolated natural disturbances such as wind damage from storms, ice or frost damage, and insect herbivory may kill individual trees and thus slow forest encroachment somewhat, but they are not of sufficient magnitude or extent to play a major role in the origin or maintenance of grass balds (White and Sutter, 1999). Natural fire frequencies are low at this elevation due to moist and cool conditions, suggesting that natural fire is unlikely to be important in grass bald origin or maintenance (Barden, 1978; White and Sutter, 1999). Furthermore, Lindsay and Bratton (1979a) argued that grass balds do not resemble pyric disclimax communities floristically, noting that recently burned areas are generally not dominated by Danthonia compressa and instead have vegetation typical of secondary successional communities at high elevations. Wiser and White (1999) also noted that fire does not eliminate woody plants, but rather can stimulate the sprouting of Rubus, Vaccinium, and other woody species known to encroach onto grass balds.

Although some early explorers of grass balds, such as Harshberger (1903), explained their formation based on topographic vulnerability to ice storms, topographic position alone cannot explain the origin or maintenance of balds because the vast majority of topographically appropriate sites within their range are forested (White and Sutter, 1999). Likewise, exposure to storms and drying from winds are unlikely causative factors for bald formation or maintenance because wind velocities are greater near many forested gaps and many of the most exposed and windy peaks are forested (Gersmehl, 1973). The fact that topographic or environmental factors alone cannot maintain grass balds has been empirically confirmed by experiments in which transplanted conifers grew successfully in grass bald sites (Brown, 1953).

Noting that grass balds are commonly located along elevational ecotones between beech-buckeye-red oak forest below and spruce-fir forest above, Billings and Mark (1957) and Mark (1958) postulated that grass balds are "primarily ecotonal or forest margin phenomena." They maintained that 
grass balds were created by past climatic changes that eliminated low-elevation ecotypes of spruce-fir species, followed by subsequent cooling in which the deciduous treeline retreated downslope faster than the spruce-fir margin could invade. Billings and Mark (1957) cited the stress regime of grass balds once they have become established (wind, drought, temperature extremes, and snow removal) as factors restricting the (re)establishment of tree seedlings. Weaknesses of this explanation, highlighted by Wells (1961), White and Sutter (1999), and others, include the relative scarcity of actual grass balds within the "bald susceptible" zone described by Billings and Mark (1957), and that it necessarily rests on an inability of spruce-fir forest to colonize suitable habitat over the course of thousands of years. Furthermore, stands of mixed hardwood forest have been found as high as approximately 1,300 feet (about 400 meters) above the ecotone, and stands of spruce-fir as much as 1,900 feet (about 600 meters) below (Gersmehl, 1973). Woody encroachment on many nongrazed grass balds also contradicts the idea that previous climate change could have created permanently deforested zones (Ramseur, 1960; Gersmehl, 1973).

Weigl and Knowles (1995) offered a hypothesis that grass balds were originally created during glacial episodes of the Pleistocene and were maintained for millennia by grazing from large herbivores. Prior to the great megafaunal extinction 10,000 years ago, these herbivores might have included mastodon, mammoth, musk ox, and ground sloth; thereafter, the primary grazers would have been bison, elk, and deer until European settlement, and then livestock thereafter. Weigl and Knowles (1995) cited Native American and European historical accounts and the presence of rare, relict, and "endemic" plants, although they acknowledged that the grass bald endemics also grow on related habitats such as high-elevation outcrops. They also pointed to archaeological excavations of a variety of Pleistocene megaherbivores less than about 60 miles (roughly 100 kilometers) from Roan Mountain and within about 180 miles (roughly 300 kilometers) of most grass balds, and they highlighted the landscape-level effects of grazing by megaherbivores, such as elephants and hippopotamuses, on other continents.

Anecdotal evidence about possible anthropogenic origins of the grass balds is mixed and contradictory. For example, some long-time residents living near grass balds have claimed that their ancestors had cleared those areas; however, some Cherokee legends also mention the grass balds, or at least treeless areas at high elevations (Gersmehl, 1973; Lindsay and Bratton, 1979b; Weigl and Knowles, 1995). Wells (1936a, b, 1961) argued that grass balds were summer camp sites and game lures maintained by Native Americans who systematically removed seedlings of fire cherry (Prunus pensylvanica) that otherwise would have initiated succession to forest. Others, including Brown (1941), Mark (1958), and Lindsay and Bratton (1979a), disputed this argument and cited the lack of Native American artifacts at grass bald sites among their critiques. Gersmehl (1973) asserted that grass balds are "19th century cultural relics" that were deliberately created by European settlers and whose persistence is dependent upon frequent grazing and fires, a hypothesis supported by empirical work by Barden (1978). Most authors acknowledge that at least some grass balds were cleared by settlers and that livestock grazing took place on most grass balds up until grazing cessation was initiated by land protection at various points in the early to mid-20th century, though this may not necessarily mean that all grass balds are of recent anthropogenic origin (Weigl and Knowles, 1995; White and Sutter, 1999). Evidence for grazing includes early photographs (Lindsay and Bratton, 1979b), early botanical accounts (White and Sutter, 1999), and fencepost remnants (Crawford and Kennedy, 2009).

Additionally, authors including Whittaker (1956) have noted general floristic similarities between grass balds and cleared fields at similar elevations. Based on analysis of vegetation data, Lindsay and Bratton (1979a) found that grass bald sites within the Great Smoky Mountains tended to separate in intermediate positions between continually disturbed communities (such as roadsides and campgrounds) and burn scars and mature forest stands. Despite disagreement over the origins of grass balds, researchers generally agree that grass balds are not currently being formed, indicating that whatever processes created the grass balds are probably different from the factors or processes responsible for their maintenance (Mark, 1958; Lindsay and Bratton, 1979b; Rentch and Fortney, 1997; White and Sutter, 1999).

Although a robust literature exists on the competing theories regarding origins and maintenance of grass balds, comparatively little attention has been paid to the creation and maintenance of heath balds. However, at least two analytical studies have provided evidence that heath balds predated European arrival by at least 500 years, possibly by several thousand years. Radiocarbon dating of base organic deposits in heath balds of Great Smoky Mountains National Park has revealed ages ranging from 1,000 to 3,000 years (Jenkins, 2007). At another heath bald site, Flat Laurel Gap near Mount Pisgah, analysis of plant macrofossils and pollen grains indicated the presence of heath shrubs for at least the past 3,000 years (Shafer, 1986). Whittaker (1956) favored an explanation for heath bald formation based on primary succession from bare rock, suggesting that succession had slowed on exposed ridges and that once heath species were well established, they effectively excluded tree establishment. White and others (2001) discounted this idea and argued that heath balds were more likely the result of localized disturbance to spruce-fir forest with an existing heath species understory. Some studies have suggested that heath balds may be created and maintained by the interaction of disturbance and chronic abiotic stress. For example, using a GIS-based analytical approach, White and others (2001) found that heath balds were associated with upper slopes, convex topography, and acidic rock type and with sites that had experienced burning following commercial logging activities. 


\section{Community Types and Vegetation Dynamics}

The highest elevation regions of the southern Appalachians are occupied by spruce-fir forest, which extends down to elevations of about 5,200 feet (roughly 1,600 meters) on southern and southwestern slopes and approximately 4,750 feet (roughly 1,450 meters) on northern and northeastern slopes, with a downslope gradient from fir to spruce dominance (Mark, 1958). At the lowest elevations of spruce-fir forest is an ecotone to high-elevation deciduous forest (Ramseur, 1960). Near this ecotone are trees of the deciduous forest at the upper reaches of their elevation tolerance, which exhibit dwarfing, stunting, and a widely spaced distribution. This physiognomy led some observers to designate these areas as "sub-alpine orchard associations" (Mark, 1958) or simply "orchards" (Cain, 1931), corresponding to the woodland community dominated by Crataegus punctata and C. flabellata and termed the Southern and Central Appalachian Hawthorn Orchard by NatureServe (2015). Grass balds, heath balds, and high-elevation rock outcrops generally are present within or above the elevational band of this ecotone, such that the forests surrounding them typically include spruce-fir forests, northern hardwood forests, and oak forests (Wiser and others, 1996).

According to ITESC classification, grass balds and heath balds are grouped together under the Southern Appalachian Grass and Shrub Bald ecological system; however, in addition to their contrasting physiognomy, grass balds and heath balds differ in a number of important ways. For example, species richness is generally much higher in grass balds than in heath balds (Ramseur, 1960; Wiser and White, 1999), and the two bald types are governed by differing successional dynamics, as explained below. Grass and heath balds, as well as highelevation rock outcrops, commonly form patches and compositional gradients from one to another such that community delineation at a particular site may not be straightforward (Schafale and Weakley, 1990). Some sites contain mosaics of heath vegetation interspersed with grass bald vegetation (fig. F-3). Some grass and heath balds are completely surrounded by hardwood or spruce-fir forest, whereas others grade into other high-elevation forest openings such as cliff faces, seepage areas, burn scars, and man-made clearings (Tucker, 1972; White and Sutter, 1999). Similarly, high-elevation rock outcrop communities in some places are surrounded by forest (generally spruce-fir at higher elevations and oak or mixed hardwood forest at lower elevations), but may also be embedded within, and grade into, grass balds, heath balds, and other forest openings (Tucker, 1972; Johnson, 1996; Wiser and others, 1996).

\section{Grass Balds}

As the name suggests, grass balds are graminoiddominated forest openings (fig. F-4). Important and characteristic species include Danthonia compressa,
D. spicata, Potentilla canadensis, Deschampsia flexuosa, Rumex acetosella, Rubus canadensis, Vaccinium vacillans, and several Aster, Solidago, Carex, and Viola species (Mark, 1958; Lindsay and Bratton, 1979a, b; Pittillo and others, 1998; White and Sutter, 1999). Three associations described by Schafale (2012) are grass bald subtypes: the grass subtype (distinguishable by the dominance of Danthonia compressa), the sedge subtype (dominated by Carex species), and the alder subtype (a unique association that is confined to the highlands near Roan Mountain, consisting of Alnus viridis ssp. crispa, Carex species, Danthonia compressa, and other herbaceous taxa). All three associations are ranked G1. Grass balds support relatively high species richness for high-elevation communities, with researchers often reporting more than 150 (sometimes more than 200) vascular plant species for a single site, most of which are grasses and sedges (White and Sutter, 1999; Wiser and White, 1999). Adding to their species richness is the presence of ecotypic populations of many forest herb species, in addition to other taxa that prefer or require open habitat (Whittaker, 1956). In his floristic survey of high-elevation communities, Ramseur (1960) documented more than twice as many species in grass balds (236) as in heath balds (102), and grass balds had greater species richness than any other high-elevation community he surveyed, although they accounted for less than 5 percent of total land area.

Within grass balds, the relative dominance of species has been shown to fluctuate seasonally (Ramseur, 1960), but the relative coverage of herbaceous versus woody species has also been shown to change directionally over the course of years, suggesting successional processes that may be attributable to changes in disturbance patterns such as grazing or drought (Mark, 1958). Investigations of vegetation dynamics in grass balds - and specifically the processes of succession and forest encroachment — have used a variety of methods, including aerial photography, historical records, dendrochronology, and geographic information systems (Crawford, 2007). Although not all findings have been in agreement, a general pattern has emerged that grass balds are highly vulnerable to woody encroachment and that, following the cessation of disturbance (grazing, mowing, or cutting), they typically succeed to forest (Mark, 1958; Ramseur, 1960; White and Sutter, 1999). Using aerial photography and tree core sampling on two grass balds in Great Smoky Mountains National Park, Lindsay and Bratton (1980) determined that nearly all trees had become established since the cessation of grazing, and they calculated approximately linear decreases in nonforested areas ranging from about 0.1 to 0.25 acre (about 0.04 to 0.1 hectare) per year. Primary species responsible for encroachment onto grass balds in Great Smoky Mountains National Park include Crataegus, Amelanchier, Vaccinium, Rhododendron, Picea, Abies, Fagus, Rubus, and Quercus species (Lindsay and Bratton, 1979b, 1980; Weigl and Knowles, 1995). Grass balds on Roan Mountain were encroached upon by Rhododendron, Picea, Abies, and Alnus species (Brown, 1941). As part of a long-term monitoring project at a grass bald site in the Balsam Mountains in North Carolina, researchers observed a bald convert from 


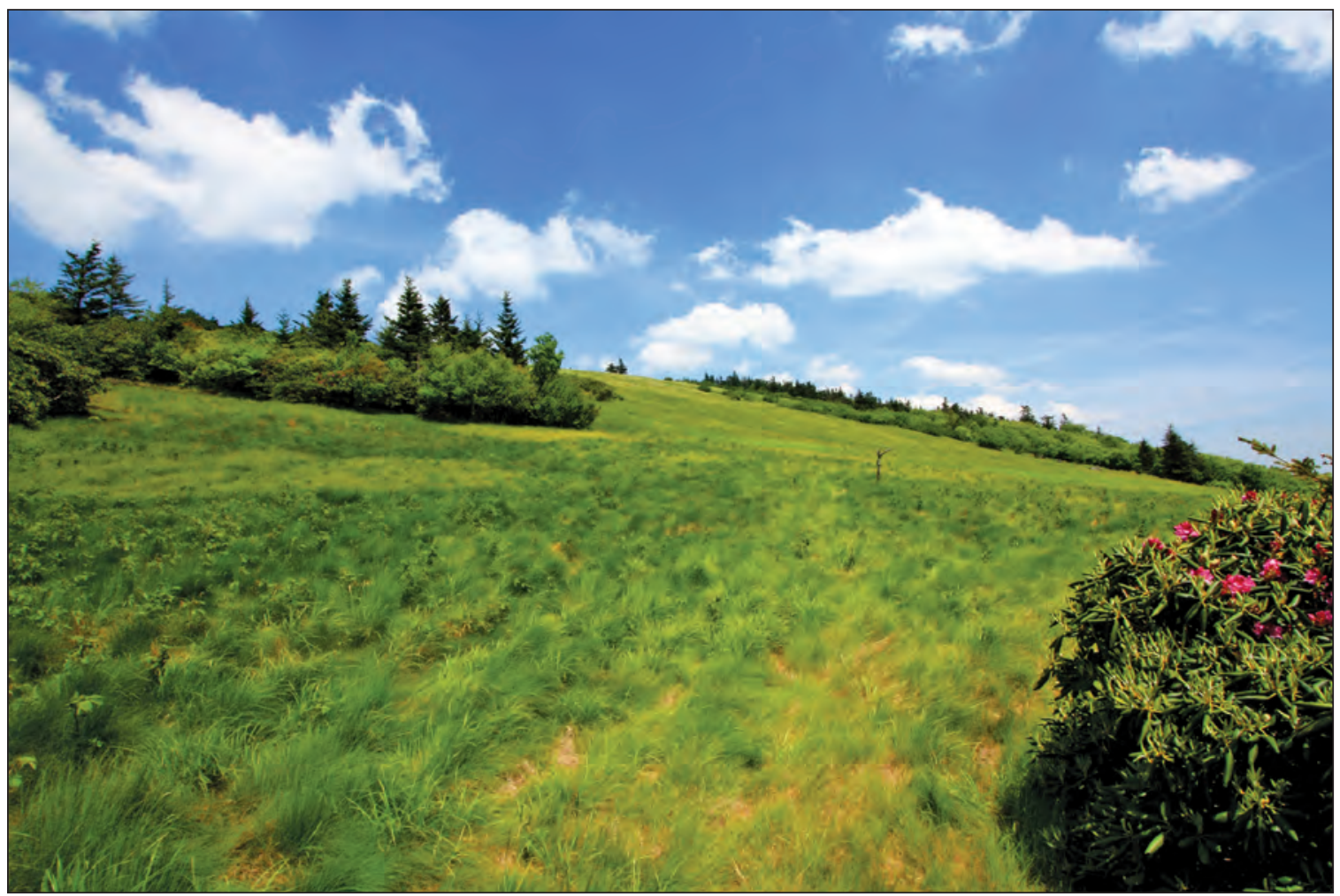

Figure F-3. Grass bald and heath bald mosaic at Round Bald, Pisgah and Cherokee National Forests, Mitchell County, North Carolina, and Carter County, Tennessee. Photograph by Alan M. Cressler, U.S. Geological Survey.

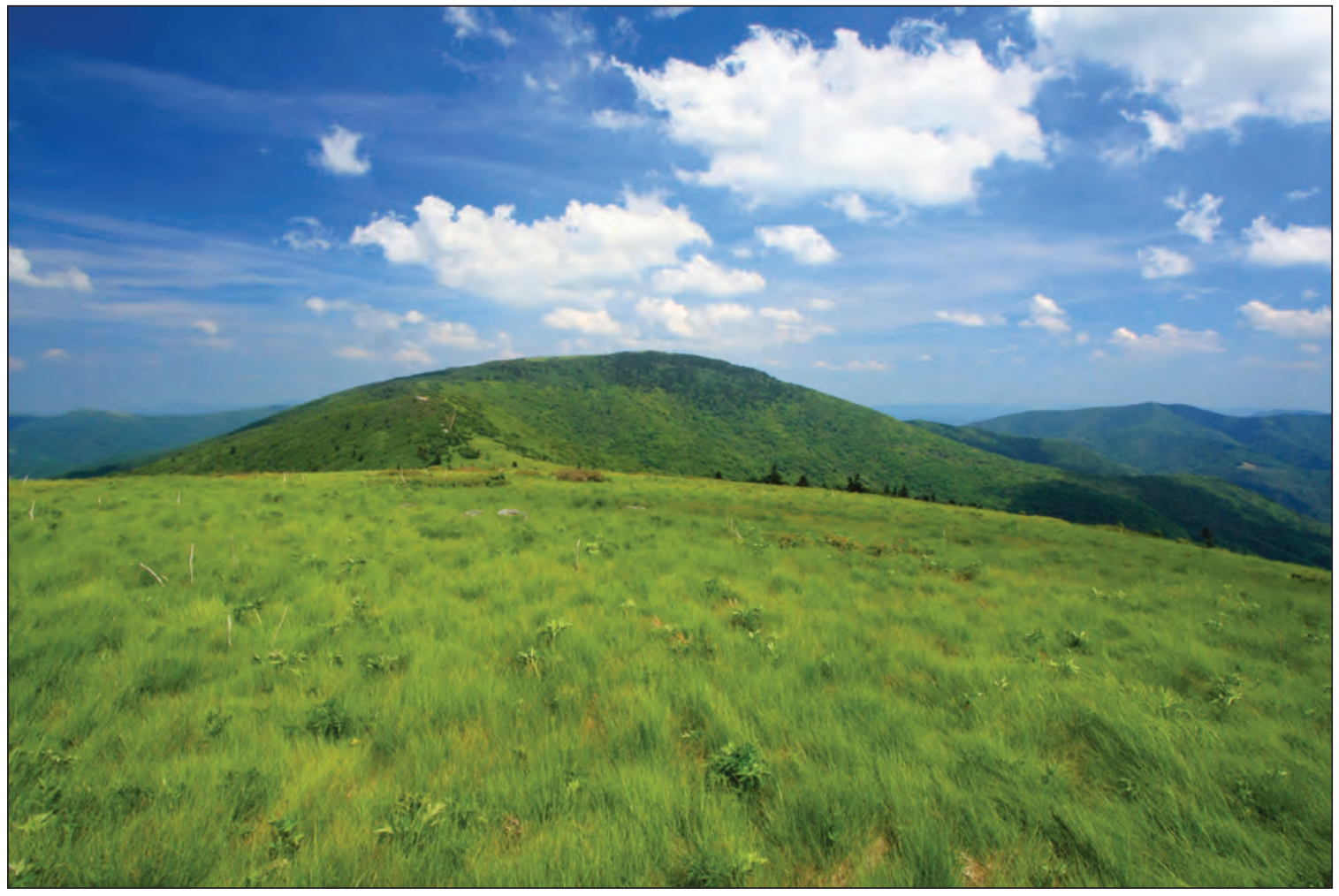

Figure F-4. Grass bald at Round Bald, Pisgah and Cherokee National Forests, Mitchell County, North Carolina, and Carter County, Tennessee. Photograph by Alan M. Cressler, U.S. Geological Survey. 
predominantly Danthonia compressa to primarily tree and shrub cover (Abies fraseri and Picea rubens) in only a few decades (Sullivan and others, 2010), with tree cover increasing 88 percent and shrub cover increasing 239 percent in the first 5 years of the study (Sullivan and Pittillo, 1988). Using tree-ring analysis, Crawford and Kennedy (2009) noted that a dramatic increase in establishment of Quercus rubra coincided temporally with the cessation of grazing at Craggy Gardens, North Carolina.

In addition to disturbance regimes, factors influencing succession trajectories and speeds in grass balds may include environmental conditions created by local topography. For example, Brown (1941) noticed that invasion of a grass bald on Roan Mountain by Rhododendron was more rapid in depressions and slower in more elevated parts of the bald, suggesting that soil moisture might play a role in determining succession speed. Physiological and life-history traits of invading species also shape succession dynamics. Woody invasion of grass balds by root-shooting and clonal expansion may be more efficient than by seed dispersal because seedling densities in grass balds are low and establishment from seed is inhibited by the dense herbaceous vegetation (White and Sutter, 1999).

Brown (1941) observed substantial encroachment into a grass bald on Roan Mountain by Rhododendron catawbiense and proposed a model of succession from bare rock to grass bald to heath bald to spruce-fir climax. Later generations of researchers, including White and others (2001), provided evidence that this model is highly oversimplified and have disputed the notion that succession of grass balds produces heath balds. However, encroachment of ericaceous shrubs into grass balds can produce what Ramseur (1960) referred to as shrub balds: communities dominated by heath shrubs but with a more diverse herbaceous component than heath balds, at least in the initial stages of encroachment. White and Sutter (1999) suggested that nonheath shrub balds may indeed represent a possible seral stage in the succession of grass balds to forest.

\section{Heath Balds}

Ramseur (1960) distinguished two primary types of heath balds: heath slicks - found on steep ridges with exposed slate and dominated by Rhododendron carolinianum - and rhododendron gardens - found on gaps, slopes, and summits and dominated by $R$. catawbiense. According to current ITESC classification, several similar and related high-elevation associations are classified as heath bald subtypes, all of which are ranked G1 or G2 (Schafale, 2012). These include heath balds categorized primarily by dominant vegetation (the Catawba rhododendron subtype, the Carolina rhododendron subtype, the southern mixed subtype, and the sand myrtle subtype) and by occurrence on slate substrate (the slate subtype). In general, heath balds tend to be species poor, dominated by relatively few species of ericaceous shrubs with a sparse herbaceous component (Whittaker, 1956; Wiser and White, 1999; Jenkins,
2007). Many ericaceous species can exist as an understory in the surrounding spruce-fir forest, such that heath balds may grade into a forest community type with a heath shrub understory - what Whittaker (1963) called a "forest heath." Disturbance to trees-whether by wind, debris slides, fire, or logging - may thus produce heath bald communities by removing canopy and exposing the understory (Peter White, University of North Carolina, written commun., 2014).

Compared to grass balds, succession in heath balds is considerably slower and is limited by a specific suite of environmental factors. Whittaker $(1956,1963)$ postulated that heath balds were stable "topographic climax" communities, a hypothesis supported by White and others (2001) who concluded based on aerial photography that heath balds in the Great Smoky Mountains National Park had not changed in area between the 1930s and 1980s. Other investigators, however, have documented forest encroachment into heath balds, albeit at rates less readily noticeable than for grass balds (Brown, 1941; Thomas and Pittillo, 1987). It is now generally accepted that succession to forest does occur in heath balds but is very slow due to extremely low $\mathrm{pH}$ (which may result in aluminum toxicity to nonadapted species), thick leaf litter, shallow soil, and shady conditions at the soil surface resulting from the very thick shrub cover (Pittillo and others, 1998; Wiser and White, 1999; Jenkins, 2007). Using dendrochronology at a bald in Craggy Gardens, Buncombe County, North Carolina, Crawford (2007) demonstrated that Quercus rubra encroachment was confined primarily to an area free of heath species, suggesting that heath species serve as a barrier that slows tree establishment. On the other hand, Thomas and Pittillo (1987), also working at Craggy Gardens, documented the encroachment of Fagus grandifolia into a heath bald dominated by Rhododendron catawbiense at a rate of approximately 10 feet (about 3 meters) per year, enabled primarily by root sprouting believed to circumvent the allelopathic defenses of Rhododendron.

\section{High-Elevation Outcrops}

High-elevation outcrops include communities characterized by exposed rock surfaces colonized by lichen and mosses (fig. F-5) as well as communities that also include graminoids, forbs, and shrubs (fig. F-6). Community composition and the presence of rare plant species in high-elevation rock outcrops depend in part on elevation, surrounding vegetation, and the age of the outcrops. Wiser and others (1996) used hierarchical clustering methods based on floristic data to distinguish nine plant community types of rock outcrops, with these community types correlating strongly to elevation, bedrock type, and surrounding vegetation composition. Peter White (University of North Carolina, written commun., 2014) distinguished between very steep outcrops that were likely never forested due to their slope and those created by debris avalanches, which tend to occur at steep, concave locations at the headwaters of first-order streams. According to ITESC 


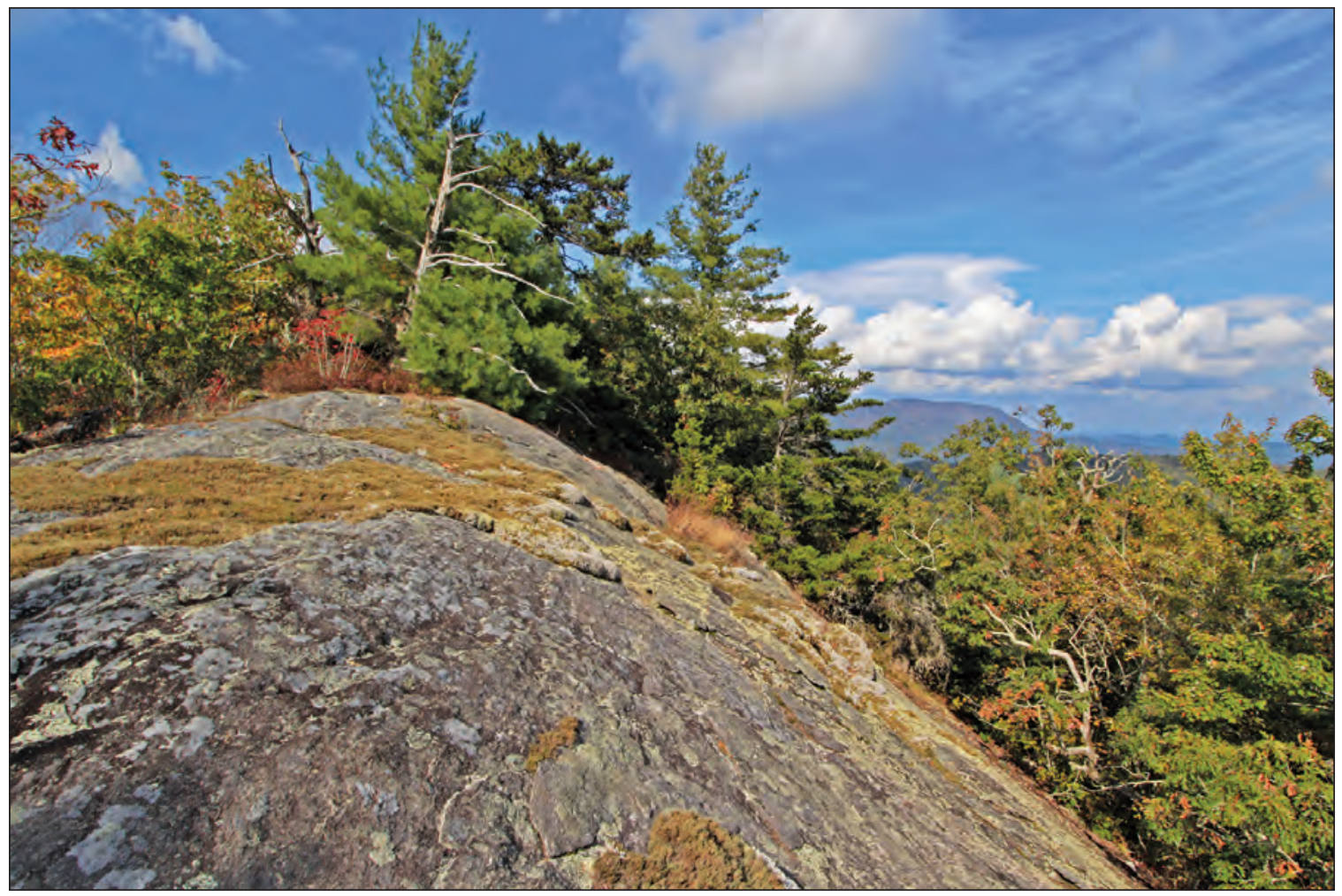

Figure F-5. Rock outcrop at Sassafrass Mountain, Nantahala National Forest, Jackson County, North Carolina. Photograph by Alan M. Cressler, U.S. Geological Survey.

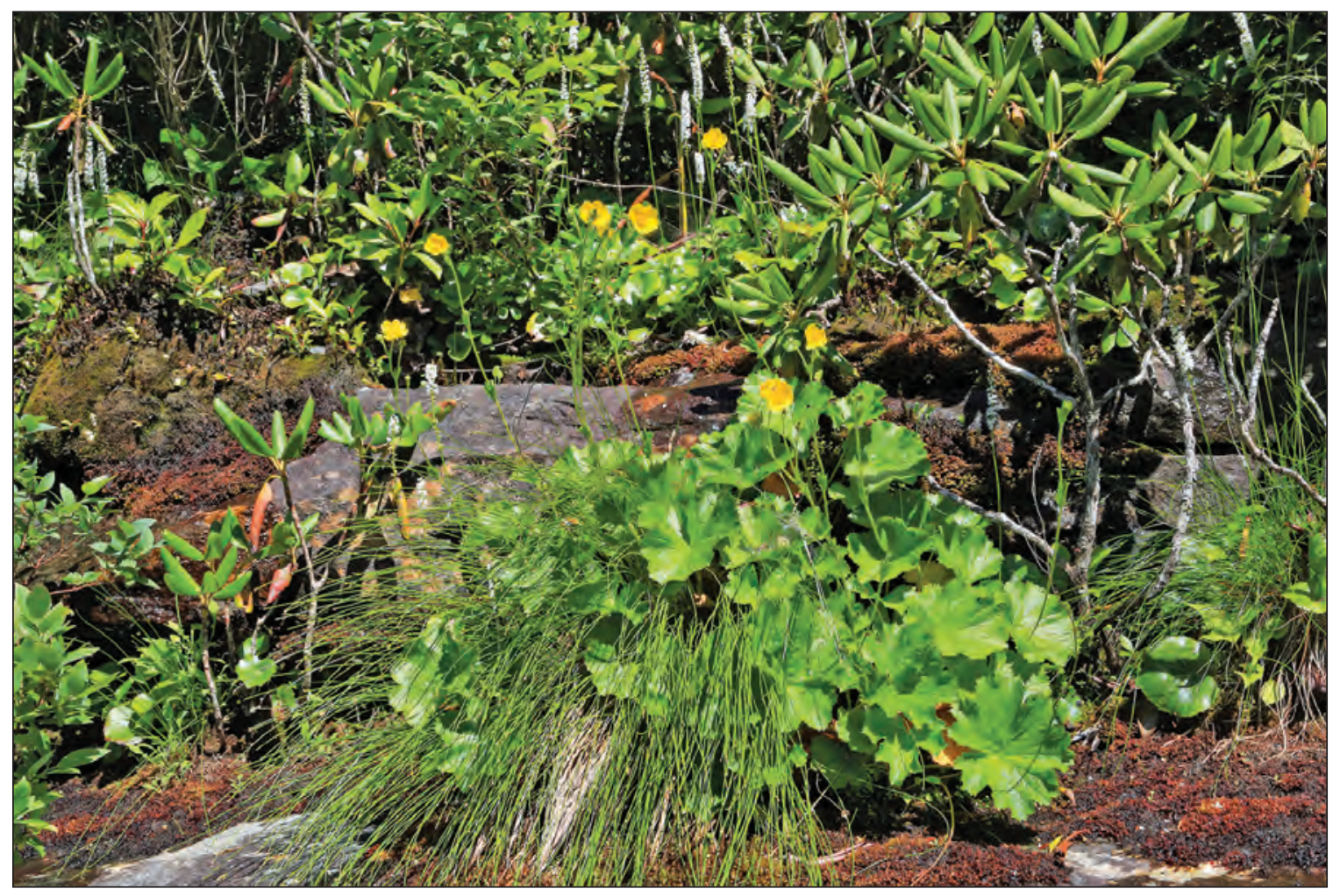

Figure F-6. High-elevation rock outcrop community, Craggy Dome, Blue Ridge Parkway, Buncombe County, North Carolina. Photograph by Alan M. Cressler, U.S. Geological Survey. 
classification, associations belonging to the High Elevation Rocky Summit include the typic subtype (which describes most outcrops within the ecosystem range), the little bluestem subtype (present on a mafic or felsic substrate with perennial seepage and sparse graminoid and forb cover), the high-peak subtype (present at only the highest elevations and generally lacking lower-elevation species such as Kalmia latifolia and Krigia montana), and the Anakeesta subtype (documented only on slate in the Anakeesta Formation in the Great Smoky Mountains, and having up to 80 percent exposed bedrock). Associations within this group generally are found in geophysical contexts characterized by irregular and fragmented rock with numerous crevices (Schafale and Weakley, 1990) and are all ranked G1 with the exception of the High Elevation Rocky Summit typic subtype, which is ranked G2. Two associations of the Southern Appalachian Granitic Dome ecological system are also high-elevation outcrop types, forming on smooth continuous rock surfaces: the highelevation granitic dome and the high-peak lichen subtype. The ninebark subtype of the Southern Appalachian Montaine Cliff and Talus ecological system may also be included as a highelevation outcrop, and is characterized by sparse vegetation on vertical amphibolite cliffs (Schafale, 2012). The high-elevation outcrop barrens (black chokeberry igneous/metamorphic type) is a component of the Southern Appalachian Grass and Shrub Bald ecological system present in Virginia and possibly North Carolina and is characterized by shrub thickets, herbaceous mats, and lichen-covered rock surfaces on strongly convex upper slopes and summits (Schafale, 2012). Vegetation dynamics in high-elevation outcrops appear to be characterized primarily by cyclic primary succession (Schafale, 2012) because slowly accumulating soil mats supporting patches of woody species are sloughed off or washed away by localized disturbance events such as tree falls, storms, exfoliation, and loss of individual boulders (Wiser and White, 1999).

\section{Contributions to Regional Biodiversity}

Wiser and White (1999) stated that high-elevation outcrops of the southern Appalachians "support one of the richest floras of rare species of any regional habitat." These outcrops and associated balds sustain many rare plant taxa (table 3-5 in appendix 3) and provide habitat to a number of animal taxa of conservation concern.

\section{Endemic and Biogeographically Disjunct Taxa}

Rare plant taxa in high-elevation outcrops and balds include taxa that are primarily restricted to high-elevation outcrops, as well as those primarily restricted to the suite of high-elevation open habitats including grass balds, heath balds, outcrops, seepage areas, and landslide scars (Wiser, 1994; Wiser and White, 1999). These habitats sustain a number of taxa that are State-listed as endangered within the southern
Appalachian region, several of which are G1- or G2-ranked narrow endemics of high-elevation outcrops: Geum radiatum (fig. F-7A), Calamagrostis cainii, Houstonia purpurea var. montana (fig. F-7B), and Solidago spithamaea (Wiser and White, 1999). Additionally, Liatris helleri was considered to be a narrow endemic to North Carolina outcrops prior to a broadening of the concept by Nesom (2005) to include occurrences recognized as Liatris turgida and L. pilosa in West Virginia and Virginia. Houstonia purpurea var. montana and Geum radiatum are federally listed endangered taxa, and Liatris helleri and Solidago spithamaea are federally listed as threatened taxa. In addition to vascular plants, high-elevation rock outcrops also support at least 15 globally rare or regionally rare bryophyte and lichen taxa, including Gymnoderma lineare (fig. F-7C), Marsupella emarginata var. latiloba, Metzgeria furcata var. setigera, Polytrichum appalachianum, Xanthoparmelia monticola, and Cephaloziella obtusilobula (Wiser and White, 1999). As pointed out by Wiser and others (1998), high-elevation outcrops are often relatively inaccessible to botanists, resulting in "woefully incomplete" knowledge of rare-species distributions. Thus, new species have been described relatively recently, such as by Anderson (1987), and others may exist that are yet to be described.

Grass and heath balds also support taxa of conservation concern. No known taxa are strict endemics to grass balds, but grass balds do provide habitat for a number of regionally rare plant species and species that might be called "near endemics" because they are endemic to the southern Appalachian region and are present in open habitats (rock outcrops, cliffs, and seeps) as well as in grass balds (Lindsay and Bratton, 1979b; Weigl and Knowles, 1995; White and Sutter, 1999). Heath and shrub balds also have no strict endemics, though in some cases they provide habitat for regionally and globally rare taxa such as Geum geniculatum and Alnus viridis ssp. crispa (Whittaker, 1956; Clarkson, 1960). Evidence suggests that rare plants endemic to high-elevation outcrops may have invaded grass balds during the process of bald formation, which provided newly suitable habitat to the outcrop endemics (Wiser and White, 1999). Thus, the richness of rare taxa supported by individual grass balds may be influenced by proximity to high-elevation rock outcrop sites (Wiser and White, 1999) and by geographic size. The grass balds of Roan Mountain are the largest and most geographically expansive in the region, supporting 19 state or federally listed or candidate taxa (Weigl and Knowles, 1995). Applying concepts from island biogeography to isolated high peaks in the southern Appalachians, White and others (1984) produced results consistent with the species-area relationship for rare plants in these ecosystems (larger "island" areas had greater numbers of rare plant taxa) and the habitat-heterogeneity hypothesis (topographic diversity was related to rare-species richness).

Several authors have noted biogeographically disjunct distributions for a number of species of high-elevation outcrops and balds, with population centers either in northern regions (such as alpine zones of northern New England and artic or boreal zones of Canada) or else in the Coastal 
Figure F-7. Characteristic taxa of high-elevation outcrops and balds: $A$, Geum radiatum, Roan Mountain, Pisgah National Forest, Mitchell County, North Carolina; B, Houstonia purpurea var. montana, Roan Mountain, Pisgah National Forest, Mitchell County, North Carolina; C, Gymnoderma lineare, Chattahoochee National Forest, Rabun County, Georgia. Photographs by Alan M. Cressler, U.S. Geological Survey.
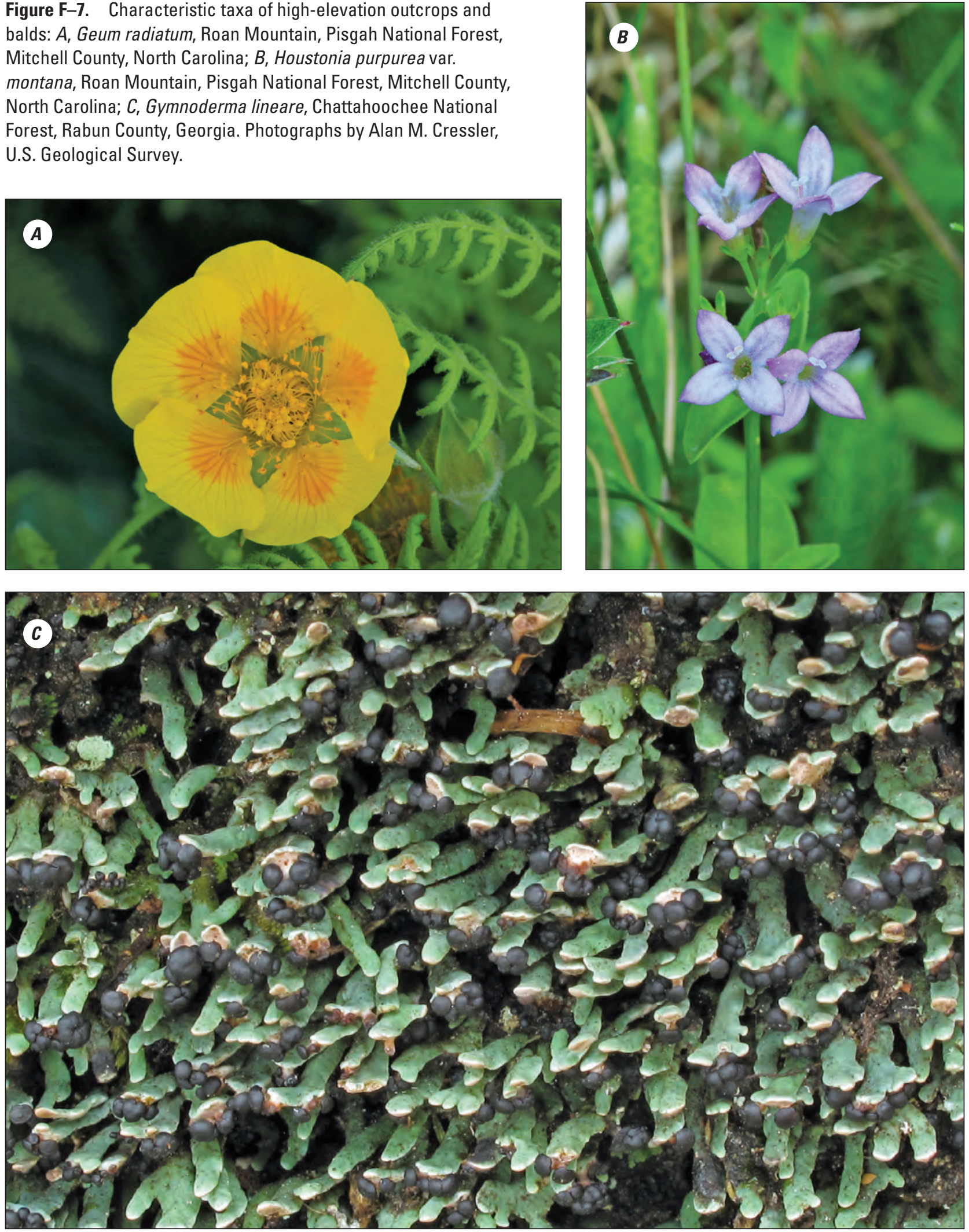
Plain (Tucker, 1972). Taxa with arctic or alpine affinities present in high-elevation outcrops and balds in the southern Appalachian region include Alnus viridis ssp. crispa, Huperzia appalachiana, Juncus trifidus, Minuartia groenlandica, Trichophorum caespitosum, Sibbaldiopsis tridentata, Agrostis mertensii, and Trisetum spicatum (Mark, 1958; Ramseur, 1960; Wiser, 1994; Wiser and others, 1996; Wiser and White, 1999). While all of these taxa are secure within their northern ranges, they are State-rare within the southern Appalachian region and thus contribute to regional biodiversity. For some species, their presence in the Appalachian region represents a profound disjunction. For example, the population of Alnus viridis ssp. crispa on Roan Mountain is disjunct by more than 740 miles (approximately 1,200 kilometers) from a northern range that extends from the mountains of New England to Labrador and Alaska (Clarkson, 1960). In addition to vascular plants, many lichens and bryophytes also display disjunction, with population centers as far away as Japan (Dey, 1978).

The presence of so many plant and lichen taxa in southern Appalachian outcrops, balds, and adjacent forests that are disjunct from treeless arctic or alpine habitats far to the north suggests that these mountains served as refugia for relic populations derived from Pleistocene alpine flora that moved southward in advance of the Wisconsin ice sheet and later retreated north during deglaciation (Ramseur, 1960; Dey, 1978; Wiser and others, 1998). Support for this hypothesized dynamic between vegetation and climate derives primarily from paleoecological evidence, including pollen and macrofossil deposition, together with the mapping of periglacial geomorphic features such as stone polygons and stone stripes (Clark, 1968; Delcourt and Delcourt, 1985, 1988). Based on these lines of evidence, climatic treelines in the southern Appalachian region were estimated to have been present near 4,600 to 4,900 feet (about 1,400 to 1,500 meters) above sea level during the last glacial maximum (approximately 18,000 years before present), such that areas at higher elevations were alpine tundra (Delcourt and Delcourt, 1985, 1988; Cogbill and others, 1997). Pleistocene relic taxa with arctic or alpine affinities are believed to have survived in high-elevation areas due to a competitive advantage in cool, exposed microclimates as regional climatic conditions warmed (Dey, 1978; Pittillo and others, 1998). This hypothesis is supported by findings that the minimum elevation for most relict species populations in the southern Appalachians was roughly 1,100-3,600 feet (about 350-1,100 meters) higher than for relict species in the northern Appalachian region (Wiser, 1998).

\section{Animal Taxa of Conservation Concern}

High-elevation outcrops and balds provide habitat to a number of rare vertebrates. Rare mammals include Corynorhinus townsendii virginianus (Virginia big-eared bat), which is federally listed as endangered, Neotoma magister (Allegheny woodrat), and $N$. floridana (eastern woodrat). Aneides aeneus (green salamander) is State-rare throughout the southern Appalachian region and typically is present at lower elevations, but has been documented on outcrops above 3,900 feet (about 1,200 meters) (Wiser and White, 1999). High-elevation balds and outcrops are important to regional avian diversity in the southern Appalachians because they contribute to regional habitat diversity in terms of microclimate, vegetation structures, and food supplies (Kendeigh and Fawver, 1981). Roan Mountain, for example, which contains the largest sized grass balds in the region, also has exceptionally high avian diversity and supports State-rare bird species including Plectrophenax nivalis (snow bunting) (Lee, 2004). Other avian taxa of conservation concern supported by high-elevation balds and outcrops include Falco peregrinus (peregrine falcon) and Aquila chrysaetos (golden eagle) (Wiser and White, 1999). However, some evidence indicates that woody encroachment is beginning to degrade the special avian habitat provided by grass balds. McConnell and McConnell (1983) found differences in bird community structure in the Unicoi Mountains over a 36-year interval, and Haney and others (2001) noted declines in particular species associated with open habitat over a 50 -year interval in the same area. Both research teams cited habitat changes as possible explanatory factors, specifically taller grass, increased shrub cover, and forest encroachment in the absence of grazing.

Information about diversity of invertebrate species associated with high-elevation balds and outcrops offers varied perspectives. Whittaker (1952) found grass and heath balds to support relatively low insect productivity and diversity compared to forested communities in the Great Smoky Mountains, and he noted a similarity in insect species composition between grass balds and alpine meadows of Eurasia. Dourson and Langdon (2012) found that species richness of land snails decreased with elevation in the Great Smoky Mountains, although heath balds were relatively species-rich for their elevation, a somewhat surprising finding given their acidic soil conditions and low calcium availability. Conversely for spiders, Toti and others (2000) observed much greater species richness in grass bald sites than in heath bald sites. Aiken and Coyle (2000), who documented microhabitat segregation between two Tetragnatha spider species in grass balds, suggested that finescale habitat heterogeneity within grass balds can be important to arthropod distribution. Van Pelt (1963) suggested that grass and heath balds are important in the distribution of many ant species within the southern Blue Ridge. Globally or regionally rare arthropod taxa supported by high-elevation outcrops and balds include insects such as Trimerotropis saxatilis (lichen grasshopper) and Spharagemon saxatile (ledge grasshopper) and spiders such as Hypochilus coylei and H. sheari (two lampshade weaver species) (Wiser and White, 1999). 


\section{Conservation Considerations}

High-elevation outcrops and balds have been foci for conservation and restoration efforts because of their biodiversity contributions and cultural importance (Johnson, 1996; White and Sutter, 1999; Wiser and White, 1999). These efforts are complicated by uneven levels of scientific understanding across ecosystem types and, in some cases, by ideological differences concerning appropriate management practices.

\section{Threats to Ecosystem Integrity}

Damage from recreational use is an often-mentioned threat to high-elevation outcrop communities (Tucker, 1972; Wiser, 1994; Wiser and others, 1996; Collins and others, 2001; Fleming and Patterson, 2012). High-elevation outcrops offering scenic views are popular destinations. As a result, trampling by hikers and rock climbers is a major threat to these communities. Even some protected sites that allow public access have been heavily damaged by trampling, with concomitant declines in rare plant populations (Johnson, 1996; Wiser and White, 1999). Through an intentional program of overlook design and trail rerouting, the National Park Service was able to effect a 97-percent reduction in visitor trampling at rock outcrops in Craggy Gardens in North Carolina (Johnson, 1996); however, the rate of vegetation recovery in previously trampled areas is unclear (Bart Johnson, University of Oregon, written commun., 2014). While some high-elevation outcrops and balds are on protected land, others lack legal protection. Thus, depending on their degree of isolation and accessibility, some outcrops and balds may be threatened by development (Wiser and White, 1999; Collins and others, 2001).

Air pollution may also threaten some species of highelevation outcrop communities. In particular, vegetation can be affected by exposure to ozone, smog haziness that alters irradiance and spectral quality of light, $\mathrm{pH}$ alteration from acid precipitation (which may lead to aluminum toxicity and cation leaching), and the deposition of nitrate, sulfate, and particulate matter (Lefohn and others, 1997; Wiser and White, 1999; Jenkins, 2007).

Exotic and invasive species also threaten the integrity of some outcrops and balds. Within Great Smoky Mountains National Park, staff are currently managing approximately 50 exotic plant species that threaten natural communities through hybridization or competitive displacement (Jenkins, 2007). Invasive weedy species mentioned as a threat to high-elevation rock outcrop communities in Virginia include Poa compressa and Rumex acetosella (Fleming and Patterson, 2012). Floristic analysis by Wiser (1994) and Wiser and White (1999), however, indicated exotic species to be only a relatively minor component of rock outcrop vegetation in Tennessee and North Carolina. In some cases, exotic pest species can pose a threat to high-elevation ecosystems such as grass balds. In response to ecosystem damage from the rooting activities of Sus scrofa (wild hogs), a hog-control program was begun in 1960 in Great Smoky Mountains National Park in which animals were trapped and killed (Howe and Bratton, 1976; Peine and Farmer, 1990). Adelges piceae ${ }^{10}$ (balsam woolly adelgid), an exotic insect species, began causing extensive Fraser fir mortality as early as the 1970s (Lindsay and Bratton, 1979a). Little is known about the effects of this Fraser fir mortality on nearby communities including highelevation outcrops and balds, although fir mortality is expected to contribute to soil erosion and increased soil drying through changes to microclimate and localized wind patterns (Wiser and White, 1999).

Although thin-to-absent soils generally exclude woody vegetation in high-elevation outcrops, woody encroachment and succession to forest are considered to be major threats for grass balds, and to a lesser extent for heath balds. Woody encroachment onto grass balds acquired in the early 1930s by Great Smoky Mountains National Park became apparent as early as the late 1930s and was recognized as a management problem in the 1950s (Lindsay and Bratton, 1979b). Active maintenance is underway at 2 grass balds in Great Smoky Mountains National Park, out of the $20-30$ balds believed to exist or have existed within the park, and at the 6 grass balds on Roan Mountain (White and Sutter, 1999).

\section{Conservation Strategies}

High-elevation outcrop and bald communities in the southern Appalachians are present on protected land in three States. Great Smoky Mountains National Park, Cherokee National Forest, Roan Mountain State Park, and land owned by the Southern Appalachian Highlands Conservancy are in Tennessee; Jefferson National Forest and Grayson Highlands State Park are in Virginia; and Nantahala National Forest, Pisgah National Forest, and land owned by The Nature Conservancy are in North Carolina (DeSelm and Murdock, 1993). Some concerns have arisen as to whether the number of grass balds currently under protected land ownership is sufficient. Because of the distribution patterns of rare species across grass balds within their range, a relatively large number of grass balds would need to be preserved if the full suite of rare species they sustain is to be conserved (Wiser and White, 1999).

Given the well-documented patterns of woody encroachment into grass balds, the question of whether they are of natural or anthropogenic origin is important not only for scientific reasons but also because of the management implications for sites on protected land. If these ecosystems are anthropogenic in origin and maintenance, then they do not

\footnotetext{
${ }^{10}$ Species name according to Encyclopedia of Life (2016).
} 
qualify as natural ecosystems according to the National Park Service, and their management would more appropriately be as "historical areas," necessitating a different set of management practices than those for natural ecosystems (Lindsay and Bratton, 1979b; Weigl and Knowles, 1995). However, even the management of grass balds as "historical areas" is complicated by uncertainty surrounding their age, and the question of what historical period to use as a management goal (White and Sutter, 1999). Mounting evidence that grass balds have been maintained (if not also created) primarily through anthropogenic disturbance has created some ideological division among conservationists, with some favoring preservation of the grass balds through continued human interference because of their aesthetic and historical value, habitat for rare species, and species richness, while others argue that the balds should be allowed to undergo succession to forest because they are essentially human artifacts on the landscape (White and Sutter, 1999).

If grass balds are to be actively managed and preserved, managers face a number of considerations in combatting woody encroachment. Best practices include hand cutting of woody species, targeted herbicide application to control sprouting in Vaccinium and Rubus species, and seeding with native plants (Wiser and White, 1999). Lindsay and Bratton (1979b) evaluated a number of management options for maintaining grass balds, such as burning, hand cutting, mowing, and grazing, and concluded that although cutting and grazing would be the most "historically correct" management strategy, a more practical approach would involve cutting followed by mowing and (or) burning. However, Jenkins (2007) noted that burning may actually accelerate woody encroachment in grass balds because it stimulates sprouting from the root collar of burned trees; he suggested that grazing and cutting be used instead. If prescribed burns are to be used to maintain balds, the appropriate burn frequency depends in part on the invading species that are being controlled and the type of bald being maintained. Rapidly sprouting species such as Vaccinium pallidum and Diervilla sessilifolia in grass balds require frequent burning, whereas heath balds require less frequent burning (Barden, 1978). Although grazing and browsing by goats have been widely suggested as a mechanism for management of grass balds to prevent succession, the effects of grazing and browsing on rare and regionally endemic plant populations have largely not been investigated. One exception is Powell (2011), who found that goat browsing did not affect morphology, reproduction, or vigor of Lilium grayi on Roan Mountain, but did result in greater numbers of juvenile plants. A further consideration for managers of grass balds is that certain woody taxa may actually play important ecological roles. In particular, the disjunct Alnus viridis ssp. crispa is a keystone species and prominent nitrogen-fixer in the G1-ranked alder subtype of grass bald that is unique to Roan Mountain (Donaldson and others, 2014; NatureServe, 2015). For these reasons, Donaldson and others (2014) argued that conservation of Alnus viridis ssp. crispa should be considered as a component of grass bald conservation on Roan Mountain rather than simply targeting it for removal along with other woody taxa.

In some cases, conservation efforts for high-elevation outcrop and bald ecosystems have included attempts to reintroduce populations of rare and endemic plants. Habitat restoration and rare-plant reintroduction projects have been undertaken by the National Park Service and the U.S. Forest Service for several rare species endemic to high-elevation outcrops (Johnson, 1996). Wiser and others (1998) asserted that effective management and reintroduction of rare plant populations hinge on thorough understanding of habitat requirements for individual species, and they evaluated predictive models for the occurrence of several high-elevation outcrop plants. Such predictive models have special value in reintroduction efforts because they can potentially identify suitable habitat for a species that it does not currently occupy - presumably due to factors such as past extinction events or dispersal limitation - and these suitable but unoccupied sites can be targeted for reintroduction. Predictive habitat models may also be used to guide searches for new populations of rare species (Wiser and others, 1998).

\section{Knowledge Gaps}

Although much has been published about grass balds, research has generally been restricted to only a few individual balds - mostly on publicly managed land such as in the Great Smoky Mountains National Park - leaving many other balds unstudied (Crawford, 2007). Rugged and inaccessible terrain has restricted efforts to catalog biodiversity in high-elevation rock outcrops and balds, such that existing species lists may well be incomplete (Wiser and others, 1998; Dourson and Langdon, 2012). In particular, species distributions, life histories, and interspecific interactions are poorly understood for nonvascular plants and most animals inhabiting these high-elevation ecosystems (Wiser and White, 1999). Understanding of the factors determining habitat suitability for rare plants is also still limited, as is knowledge of the full ranges of these taxa (Wiser and others, 1998). Additionally, there have been few empirical investigations of the genetic effects of small population size and habitat fragmentation for rare taxa, although population genetic theory suggests these effects might include founder effects and genetic drift resulting in inbreeding depression (Godt and others, 1996). 


\section{Possible Ecological Effects From Climate Change}

Globally, upslope range-shifting in response to recent warming has been documented for a number of plant and animal species across a range of ecosystems (Walther, 2010). Species with arctic or alpine affinities in high-elevation habitats in the southern Appalachians, including disjunct and regionally rare populations derived from Pleistocene alpine flora, are likely to be growing near their tolerance limits for warm temperature. For example, Cogbill and others (1997) estimated that the current distributions of these plant populations are about 1,300 to 3,300 feet (roughly 400 to 1,000 meters) lower than would be expected based on their preferred temperature regimes. If this is the case, these populations could be especially sensitive to climate warming and could be vulnerable to competitive displacement by lowerelevation species migrating upslope. Warmer temperatures may be especially threatening to high-elevation outcrop taxa if higher-elevation habitats are not readily available for them to colonize (Wiser and White, 1999). The possible effects of climate change on grass balds may be mediated in large part by woody encroachment, indicating the need for research on the climate-growth relationships of the species responsible for tree encroachment onto balds (Crawford and Kennedy, 2009). Asymmetrical rates of upslope range-shifting have been documented in other regions, such that taxa from lower elevations invade more quickly than existing taxa recede upward (Walther and others, 2002; Loarie and others, 2009). Interspecific differences in dispersal abilities and climate-tolerance thresholds might also be expected to result in changes to community composition in high-elevation outcrops and balds (Walther and others, 2002). Because grass balds are associated with the elevational ecotone between high-elevation hardwood and spruce-fir forest (Mark, 1958), an understanding of the dynamics of upslope ecotone migration resulting from warmer temperatures may have direct implications for management of grass balds (Crawford, 2007).

Another important mechanism by which climate change might affect high-elevation Appalachian communities is through reduced cloud immersion, a climate-change-linked phenomenon already causing ecosystem destruction in tropical mountain cloud forests as cloud-base elevations rise (Pounds and others, 1999; Foster, 2001). Because cloud immersion affects a broad array of environmental factors including water input, temperature, quantity and quality of solar irradiance, and evapotranspiration, decreased cloud immersion would likely have profound but also complicated effects on highelevation Appalachian communities (Johnson and Smith, 2008). Few studies have addressed this potential threat to the southern Appalachians, either at the species level or the ecosystem level.

\section{References}

Aiken, M., and Coyle, F., 2000, Habitat distribution, life history and behavior of Tetragnatha spider species in the Great Smoky Mountains National Park: Journal of Arachnology, v. 28, no. 1, p. 97-106.

Anderson, L., 1987, A new species of Polytrichum from the Southern Appalachians: Bryologist, v. 90, no. 1, p. 1-5.

Barden, L., 1978, Regrowth of shrubs in grassy balds of the Southern Appalachians after prescribed burning: Castanea, v. 43 , no. 4 , p. $238-246$.

Billings, W., and Mark, A., 1957, Factors involved in the persistence of montane treeless balds: Ecology, v. 38, no. 1, p. $140-142$.

Brown, D., 1941, Vegetation of Roan Mountain-A phytosociological and successional study: Ecological Monographs, v. 11, no. 1, p. 61-97.

Brown, D., 1953, Conifer transplants to a grassy bald on Roan Mountain: Ecology, v. 34, no. 3, p. 614-617.

Cain, S., 1931, Ecological studies of the vegetation of the Great Smoky Mountains of North Carolina and Tennessee. I. Soil reaction and plant distribution: Botanical Gazette, v. 91 , no. 1, p. 22-41.

Clark, G., 1968, Sorted patterned ground-New Appalachian localities south of the glacial border: Science, v. 161, p. 355-356.

Clarkson, R., 1960, Notes on the distribution of Alnus crispa in Eastern North America: Castanea, v. 25, no. 2, p. 83-86.

Cogbill, C., White, P., and Wiser, S., 1997, Predicting treeline elevation in the southern Appalachians: Castanea, v. 62, no. 3, p. 137-146.

Collins, B., White, P., and Imm, D., 2001, Introduction to ecology and management of rare plants of the southeast: Natural Areas Journal, v. 21, no. 1, p. 4-11.

Conkle, L., Young, R., Bochicchio, C., and Khiel, A., 2003, Why go bald? Understanding the age and origin of southern Appalachian heath balds in Great Smoky Mountains National Park, in Proceedings of the Geological Society of America 2003 Annual Meeting: Seattle, Wash.

Crawford, C., 2007, A dendrochronological analysis of vegetation change and climate history in two southern appalachian balds, Craggy Gardens and Big Bald, N.C.: Blacksburg, Va., Virginia Polytechnic Institute and State University, Masters Thesis. 
Crawford, C., and Kennedy, L., 2009, Spatial and temporal patterns of tree encroachment into a southern Appalachian grass/heath bald using tree rings: Natural Areas Journal, v. 29 , no. 4 , p. $367-375$.

DeSelm, H., and Murdock, N., 1993, Grass-dominated communities, in Martin, W., Boyce, S., and Echternacht, A., eds., Biodiversity of the southeastern United StatesUpland terrestrial communities: New York, John Wiley and Sons, Inc., p. 87-141.

Delcourt, H., and Delcourt, P., 1985, Quaternary palynology and vegetation history of the southern United States, in Bryant, V., and Holloway, R., eds., Pollen records of lateQuaternary North American sediments: Dallas, Texas, American Association of Stratigraphic Paylonologists Foundation, p. 1-37.

Delcourt, H., and Delcourt, P., 1988, Quaternary landscape ecology - Relevant scales in space and time: Landscape Ecology, v. 2, p. 23-44.

Dey, J., 1978, Fruticose and foliose lichens of the highmountain areas of the southern Appalachians: The Bryologist, v. 81, no. 1, p. 1-93.

Donaldson, J., Dinkins, Z., Levy, F., and Nandi, A., 2014, Surface-soil properties of alder balds with respect to grassy and rhododendron balds on Roan Mountain, North Carolina-Tennessee: Southeastern Naturalist, v. 13, no. 2, p. 277-395.

Dourson, D., and Langdon, K., 2012, Land snails of selected rare high elevation forests and heath balds of the Great Smoky Mountains National Park: Journal of North Carolina Academy of Science, v. 128, no. 2, p. 27-32.

Encyclopedia of Life, 2016, Encyclopedia of Life, accessed February 18, 2016, at http://www.eol.org.

Fenneman, N., and Johnson, D., 1946, Physical divisions of the United States: U.S. Geological Survey map prepared in cooperation with the Physiographic Commission, scale $1: 7,000,000$.

Fleming, G., and Patterson, K., 2012, Natural communities of Virginia-Ecological groups and community types: Richmond, Va., Virginia Department of Conservation and Recreation, Division of Natural Heritage.

Foster, P., 2001, The potential negative impacts of global climate change on tropical montane cloud forests: EarthScience Reviews, v. 55, no. 1-2, p. 73-106.

Gersmehl, P., 1973, Pseudo-timberline-The southern Appalachian grassy balds: Arctic and Alpine Research, v. 5 , no. 3 , p. $137-139$.
Godt, M., Johnson, B., and Hamrick, J., 1996, Genetic diversity and population size in four rare southern Appalachian plant species: Conservation Biology, v. 10, no. 3, p. 796-805.

Haney, J., Lee, D., and Wilbert, M., 2001, A half-century comparison of breeding birds in the southern Appalachians: The Condor, v. 103 , no. 2, p. 268-277.

Harshberger, J., 1903, An ecologic study of the flora of mountainous North Carolina: Botanical Gazette, v. 36, no. 5 , p. $368-383$.

Howe, T., and Bratton, S., 1976, Winter rooting activity of the European wild boar in the Great Smoky Mountains National Park: Castanea, v. 41, no. 3, p. 256-264.

Jenkins, M., 2007, Vegetation communities of Great Smoky Mountains National Park: Southeastern Naturalist, v. 6, Special Issue 1, p. 35-56.

Johnson, B., 1996, Southern Appalachian rare plant reintroductions on granite outcrops, in Falk, D., Millar, C., and Olwell, M., eds., Restoring diversity-Strategies for reintroduction of endangered plants: Washington, D.C., Island Press, p. 433-444.

Johnson, D., and Smith, W., 2008, Cloud immersion alters microclimate, photosynthesis and water relations in Rhododendron catawbiense and Abies fraseri seedlings in the southern Appalachian Mountains, USA: Tree physiology, v. 28 , no. 3, p. 385-392.

Kendeigh, S., and Fawver, B., 1981, Breeding bird populations in the Great Smoky Mountains, Tennessee and North Carolina: The Wilson Bulletin, v. 93, no. 2, p. 218-242.

Lee, D., 2004, North Carolina's mountain region, in Golder, W., and Smalling, C., eds., Important Bird Areas of North Carolina: Chapel Hill, N.C., Audubon North Carolina Chapter, p. 107-146.

Lefohn, A., Jackson, W., Shadwick, D., and Knudsen, H., 1997, Effect of surface ozone exposures on vegetation grown in the southern Appalachian mountains-Identification of possible areas of concern: Atmospheric Environment, v. 31, no. 11, p. 1695-1708.

Lindsay, M., and Bratton, S., 1979a, The vegetation of grassy balds and other high elevation disturbed areas in the Great Smoky Mountains National Park: Bulletin of the Torrey Botanical Club, v. 106, no. 4, p. 264-275.

Lindsay, M., and Bratton, S., 1979b, Grassy balds of the Great Smoky Mountains - Their history and flora in relation to potential management: Environmental Management, v. 3, no. 5 , p. $417-430$. 
Lindsay, M., and Bratton, S., 1980, The rate of woody plant invasion on two grassy balds: Castanea, v. 45 , no. 2 , p. $75-87$.

Loarie, S., Duffy, P., Hamilton, H., Asner, G., Field, C., and Ackerly, D., 2009, The velocity of climate change: Nature, v. 462, no. 7276 , p. 1052-1055.

Mark, A., 1958, The ecology of the southern Appalachian grass balds: Ecological Monographs, v. 28, no. 4, p. 293-336.

McConnell, J., and McConnell, O., 1983, Breeding birds of the Unicoi Mountains: The Chat, v. 47, p. 33-40.

McCracken, R., Shanks, R., and Clebsch, E., 1962, Soil morphology and genesis at higher elevations of the Great Smoky Mountains: Soil Science Society of America Journal, v. 26, no. 4, p. 384-388.

NatureServe, 2015, NatureServe Explorer-An online encyclopedia of life [web application], ver. 7.1, accessed October 7, 2015, at http://www.natureserve.org/explorer.

Nesom, G., 2005, Broadened concept of Liatris helleri (Asteraceae: Eupatorieae): SIDA, Contributions to Botany, v. 21, no. 3, p. 1323-1333.

Peine, J., and Farmer, J., 1990, Wild hog management program at Great Smoky Mountains National Park, in Proceedings of the Fourteenth Vertebrate Pest Conference: Lincoln, Nebr.

Pittillo, J., Hatcher, R., and Buol, S., 1998, Introduction to the environment and vegetation of the Southern Blue Ridge Province: Castanea, v. 63, no. 3, p. 202-216.

Pounds, J., Fogden, M., and Campbell, J., 1999, Biological response to climate change on a tropical mountain: Nature, v. 398, p. 611-615.

Powell, J., 2011, Impacts of goat browsing and disease on Lilium grayi, Gray's Lily, on Roan Mountain: Johnson City, Tenn., East Tennessee State University, Masters Thesis.

Ramseur, G., 1960, The vascular flora of high mountain communities of the southern Appalachians: Journal of the Elisha Mitchell Scientific Society, v. 76, no. 1, p. 82-112.

Rentch, J., and Fortney, R., 1997, The vegetation of West Virginia grass bald communities: Castanea, v. 62, no. 3, p. 147-160.

Schafale, M., 2012, Guide to the natural communities of North Carolina, fourth approximation: Raleigh, N.C., North Carolina Natural Heritage Program.

Schafale, M., and Weakley, A., 1990, Classification of the natural communities of North Carolina, third approximation: Raleigh, N.C., North Carolina Natural Heritage Program.
Shafer, D., 1986, Flat Laurel Gap bog, Pisgah Ridge, North Carolina - Late Holocene development of a high-elevation heath bald: Castanea, v. 51, no. 1, p. 1-10.

Sullivan, J., and Pittillo, J., 1988, Succession of woody plants into a high elevation grassy bald of the Balsam Mountains: Castanea, v. 53, no. 4, p. 245-251.

Sullivan, J., Pittillo, J., and Keen, T., 2010, Invasion of Abies fraseri and Picea rubens in a southern Appalachian grassy bald over 30 years, in Proceedings of the 95th ESA Annual Meeting: Pittsburg, $\mathrm{Pa}$.

Thomas, R., and Pittillo, J., 1987, Invasion of Fagus grandifolia Ehrh. into a Rhododendron catawbiense Michx. heath bald at Craggy Gardens, North Carolina: Castanea, v. 52, no. 3 , p. $157-165$.

Toti, D., Coyle, F., and Miller, J., 2000, A structured inventory of Appalachian grass bald and heath bald spider assemblages and a test of species richness estimator performance: Journal of Arachnology, v. 28, no. 3, p. 329-345.

Tucker, G., 1972, The vascular flora of Bluff Mountain, Ashe County, North Carolina: Castanea, v. 37, no. 1, p. 2-26.

U.S. Geological Survey, National Gap Analysis Program, 2011, Land cover data portal, accessed December 2015 at http://gapanalysis.usgs.gov/gaplandcover/data/download/.

VanPelt, A., 1963, High altitude ants of the southern Blue Ridge: American Midland Naturalist, v. 69, no. 1, p. 205-223.

Walther, G., 2010, Community and ecosystem responses to recent climate change: Philosophical Transactions of the Royal Society, B, v. 365, p. 2019-2024.

Walther, G., Post, E., Convey, P., Menzel, A., Paremesan, C., Beebee, T., Fromentin, J., Hoegh-Guldberg, O., and Bairlein, F., 2002, Ecological responses to recent climate change: Nature, v. 416, p. 389-395.

Weigl, P., and Knowles, T., 1995, Megaherbivores and southern Appalachian grass balds: Growth and Change, v. 26 , no. 3 , p. $365-382$.

Wells, B., 1936a, Andrews Bald-The problem of its origin: The Journal of the Southern Appalachian Botanical Club, v. 1 , no. 5 , p. 59-62.

Wells, B., 1936b, Origin of the southern Appalachian grass balds: Science, v. 83, no. 2151, p. 283.

Wells, B., 1961, The southern Appalachian grass bald problem: Castanea, v. 26, no. 2, p. 98-100.

White, P., Miller, R., and Ramseur, G., 1984, The speciesarea relationship of the southern Appalachian high peaks - Vascular plant richness and rare plant distributions: Castanea, v. 49, no. 2, p. 47-61. 
White, P., and Sutter, R., 1999, Managing biodiversity in historic habitats - Case history of the southern Appalachian grassy balds, in Peine, J., ed., Ecosystem management for sustainability_-Principles and practices illustrated by a regional biosphere reserve cooperative: Washington, D.C., Lewis Publishers, p. 375-395.

White, P., Wilds, S., and Stratton, D., 2001, The distribution of heath balds in the Great Smoky Mountains, North Carolina and Tennessee: Journal of Vegetation Science, v. 12, no. 4, p. 453-466.

Whittaker, R., 1952, A study of summer foliage insect communities in the Great Smoky Mountains: Ecological Monographs, v. 22, no. 1, p. 1-44.

Whittaker, R., 1956, Vegetation of the Great Smoky Mountains: Ecological Monographs, v. 26, no. 1, p. 1-80.

Whittaker, R., 1963, Net production of heath balds and forest heaths in the Great Smoky Mountains: Ecology, v. 44, no. 1, p. 176-182.

Wiser, S., 1993, Vegetation of high-elevation rock outcrops of the southern Appalachians - Composition, environmental relationships, and biogeography of communities and rare species: Chapel Hill, N.C., University of North Carolina, Ph.D. dissertation.
Wiser, S., 1994, High-elevation cliffs and outcrops of the southern Appalachians: vascular plants and biogeography: Castanea, v. 59, no. 2, p. 85-116.

Wiser, S., 1998, Comparison of southern Appalachian highelevation outcrop plant communities with their northern Appalachian counterparts: Journal of Biogeography, v. 25, no. 3, p. 501-513.

Wiser, S., Peet, R., and White, P., 1996, High elevation rock outcrop vegetation of the southern Appalachian Mountains: Journal of Vegetation Science, v. 7, no. 5, p. 703-722.

Wiser, S., Peet, R., and White, P., 1998, Prediction of rareplant occurrence-A southern Appalachian example: Ecological Applications, v. 8, no. 4, p. 909-920.

Wiser, S., and White, P., 1999, High elevation outcrops and barrens of the southern Appalachian mountains, in Anderson, R., Fralish, J., and Baskin, J., eds., Savannas, barrens, and rock outcrop plant communities of North America: New York, Cambridge University Press, p. 119-132. 


\section{Chapter G. Carolina Bays}

\section{Introduction}

Carolina bays (fig. G-1) are a class of depression wetlands in the Coastal Plain that support a diverse suite of community types along hydrologic gradients from open water to xeric conditions (Kirkman and others, 2012). The name "Carolina bay" derives from the geographic concentration of this ecosystem in North and South Carolina and from the frequent presence of bay tree species (Gordonia lasianthus, Magnolia virginiana, Persea palustris, and P. borbonia) (Bennett and Nelson, 1991; Lide, 1997). Carolina bays contribute to regional biodiversity by providing habitat to a number of plant taxa of conservation concern, as well as to diverse assemblages of amphibian, reptile, and invertebrate taxa.

\section{Geographic Range}

Carolina bays are present within the Embayed and Sea Island sections of the Coastal Plain Physiographic Province (Fenneman and Johnson, 1946), hereafter referred to as the Atlantic Coastal Plain, from northern Florida to New Jersey (Prouty, 1952; Sharitz, 2003). Within North and South Carolina, the Inner Coastal Plain extends from the Fall Line (the Piedmont boundary) seaward to the Orangeburg Scarp (see fig. 17-2 in Soller and Mills, 1991). Seaward from the Orangeburg Scarp, the Middle Coastal Plain is partly dissected with elevations from roughly 100 to 300 feet (about 30 to 90 meters) above sea level and extends to the Outer Coastal Plain, which is a gently seaward-sloping set of terraces

Figure G-1. Aerial view of Dry Bay, Savannah River National Environmental Research Park, South Carolina. Photograph by Linda Lee, Savannah River Ecology Laboratory. 
generally below 100 feet (about 30 meters) of elevation with poorly dissected topography (Soller and Mills, 1991; Tesoriero and others, 2004). Carolina bays are particularly common within the Middle Coastal Plain and the older terraces of the Outer Coastal Plain, with a region of high density extending roughly from the Ogeechee River area in eastern Georgia to the Cape Fear region of North Carolina (Sharitz and Gibbons, 1982; Lide, 1997; Ross, 2003). Within South Carolina, the greatest concentration of Carolina bays is in a band approximately
60 miles (about 100 kilometers) wide, extending northeast to southwest and generally coinciding with the Orangeburg Scarp and the Surry Scarp (Lide, 1997; Willoughby and others, 2005). Within Maryland and Virginia, bays are restricted to the Delmarva Peninsula, where they are referred to as Delmarva bays (Olivero and Zankel, 2001), and to the Outer Coastal Plain (Tyndall and others, 1990). Figure G-2 shows the regions of highest concentrated occurrence of Carolina bays according to Lide (1997) and Ross (2003).

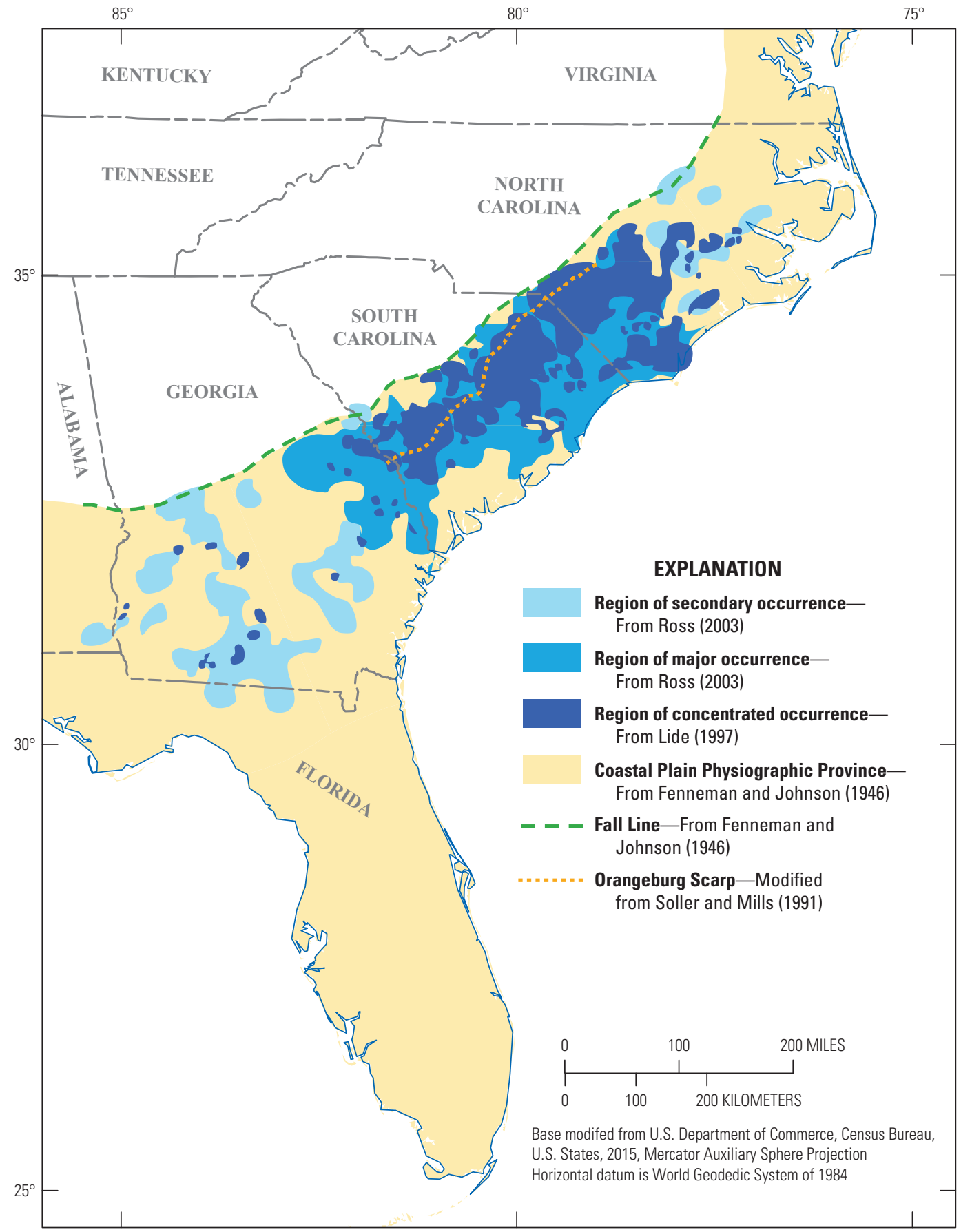

Figure G-2. Regions of concentrated occurrence of Carolina bays. 


\section{Physical Geography}

\section{Surficial Geology and Geomorphology}

Geographic differences in soil and vegetation characteristics of Coastal Plain depression wetlands have led some ecologists to differentiate between "clay-based" Carolina bays of the Inner Coastal Plain and "peat-based" Carolina bays of the Middle and Outer Coastal Plain, noting that the latter commonly have thicker organic deposits, more ombrotrophic hydrologic conditions, and a greater occurrence of pocosin vegetation, pond cypress savanna, and cypress pond community types (Newman and Schalles, 1990; Bennett and Nelson, 1991; Sharitz, 2003). On the poorly dissected sandy surficial units of the Middle and Outer Coastal Plain, Carolina bays commonly have identifiable sand rims, an elliptical shape, and a northeast-southwest orientation, they are erosional in origin (aeolian or wave action), and have hydroperiods and geochemistry favorable to peat accumulation (Prouty, 1952; Bennett and Nelson, 1991; Lide, 1997; Sharitz, 2003; Kirkman and others, 2012).

Geomorphic classification of depression wetlands of the Inner Coastal Plain, including "clay-based" Carolina bays, is more problematic. Sediments in this region, extending between the Fall Line to the west and the Orangeburg Scarp to the east (with the eastern boundary somewhat ambiguous north of the Cape Fear River valley), are more highly dissected, weathered, and colluviated than those of the Outer Coastal Plain (Soller and Mills, 1991). Depression wetlands in this region tend to have mineral soils and may lack identifiable sand rims or a clear angled-ellipse orientation (Richardson and Gibbons, 1993). Some of these wetlands may be analogous or equivalent to the Citronelle ponds of the East Gulf Coastal Plain described by Folkerts (1997), with their origins linked to solution-subsidence of kaolinite and iron-oxide materials (Diane De Steven, U.S. Department of Agriculture Forest Service, written commun., 2014). Although clear geographic differences exist in the hydrologic and ecological characteristics of Atlantic Coastal Plain depression wetlands, the relationship between these differences and the underlying surficial geology has not been conclusively resolved. Indeed, the term "Carolina bay" has been widely applied to a diverse array of depression wetlands contexts, with no clear scientific consensus concerning geomorphic and geologic criteria for inclusion (Lide, 1997).

Uncertainty regarding the number of extant Carolina bays stems not only from disagreement as to their geomorphic definition but also from the size limits of detection because many are smaller than the mapping units of the National Wetlands Inventory (Sharitz, 2003). Carolina bays range in size from less than 2 acres (less than 1 hectare) to more than 1,000 acres (hundreds of hectares) ${ }^{11}$ with smaller bays

\footnotetext{
${ }^{11}$ Published estimates of the upper limit on Carolina bay size greater than 8,900 acres (about 3,600 hectares) require the inclusion of Lake Waccamaw, which is an outlier in terms of size and which may not actually be a Carolina bay (Diane De Steven, U.S. Department of Agriculture Forest Service, written commun., 2014).
}

outnumbering larger bays (Bennett and Nelson, 1991; Sharitz, 2003). Semlitsch and Bodie (1998), for example, found that 46 percent of bays at the Savannah River National Environmental Research Park near Aiken, South Carolina were about 3 acres (1.2 hectares) or smaller and 87 percent were about 10 acres (4 hectares) or smaller. Throughout their geographic range, the total number of Carolina bays in existence is probably between 10,000 and 20,000, although estimates have been as high as 500,000 (Prouty, 1952; Sharitz and Gibbons, 1982; Sharitz, 2003).

\section{Soil and Water Characteristics}

The mineral content of Carolina bay soils or sediments is commonly dominated by quartz, but also includes vermiculite, kaolinite, feldspars, and mica (Ewing, 2003). Many Carolina bays have some amount of surface peat deposit, ranging from less than half an inch (roughly 1 centimeter) to greater than 13 feet (about 4 meters), underlain by a black sapric muck that overlies a mineral base (Ewing, 2003; Sharitz, 2003). Limited research on cation availability in Carolina bay soils suggests generally low levels of exchangeable calcium, magnesium, and potassium (Sharitz, 2003) and low levels of total cations (Schalles and others, 1989). Carolina bay soils are typically very acidic ( $\mathrm{pH}$ ranging from 3 to 5), with high organic carbon content within the surface horizons (Ewing, 2003).

Carolina bay waters are generally soft (low in calcium), acidic ( $\mathrm{pH}$ ranging from 3.5 to 6), dystrophic, and low in total cations, with variability among Carolina bays in concentrations of other water-quality constituents including sulfate, dissolved oxygen, and manganese (Schalles and others, 1989; Mahoney and others, 1990; Newman and Schalles, 1990). Factors influencing water chemistry include landscape position, surficial geology, surrounding land use, vegetation type, disturbance regime, hydroperiod, and degree of hydrologic connectivity to groundwater and surface water (Kirkman and others, 2012). Water temperature and dissolved-oxygen concentrations may be stratified according to water depth, with stratification intensifying during the growing season corresponding to coverage by macrophytes (Schalles and others, 1989; Schalles and Shure, 1989).

\section{Hydrologic Connectivity}

Early assumptions of complete hydrologic isolation for Carolina bays - based largely on observed perched water and widely fluctuating water levels - have been challenged by recent investigations demonstrating connectivity to surfacedrainage networks and (or) to shallow groundwater (Lide, 1995; Pyzoha and others, 2008). Some Carolina bays have small creeks draining into them, and some are the headwaters for perennial streams; however, many others are only seasonally connected to surface-drainage networks by natural overflow outlets (Lide, 1997). Because of the surrounding low relief and well-drained sandy soils, overland flow into and out 
of many Carolina bays is typically limited to only the most extreme precipitation events, such as hurricanes (Sharitz, 2003; Barton and others, 2008). However, some Carolina bays on the Virginia coast and on the Delmarva Peninsula are flooded under high tides and so they are connected to the Chesapeake Bay and are not strictly freshwater wetlands (Sharitz, 2003).

The hydrologic regimes of individual bays also commonly involve complex and sporadic interactions with shallow groundwater. Hydrologic modeling indicates that certain Carolina bays can be involved in groundwater recharge and discharge, and can function as flow-through wetlands, depending on precipitation levels (Phillips and Shedlock, 1993; Lide, 1995; Sun and others, 2006; Vepraskas and others, 2007; Pyzoha and others, 2008). The degree of connectivity to groundwater is determined by the interaction of numerous site-specific factors including water-table fluctuations and landscape position (Sun and others, 2006; Vepraskas and others, 2007). For example, De Steven and Toner (2004) found that bays located on river terraces showed less variability in hydroperiod than did upland bays, consistent with the likely influence of groundwater for bays in close proximity to rivers. Subsurface topography and stratigraphy also influence the degree of groundwater connectivity because many Carolina bays are underlain by layers of humate-infused sand or by alternating layers of sand and clay that function as confining layers, slowing vertical drainage and resulting in a perched water table (Schalles and others, 1989; Bennett and Nelson, 1991; Sharitz, 2003; Barton and others, 2008; Kirkman and others, 2012). The degree of hydrologic connectivity influences water chemistry and vegetation structure in Carolina bays, such that vegetation community types can sometimes be separated along a gradient from minerotrophic, groundwaterinfluenced sites to ombrotrophic, hydrologically isolated sites (Newman and Schalles, 1990).

\section{Stress and Disturbance Regimes}

Some Carolina bays seasonally range from inundated to dry, while others are generally inundated with fluctuating water levels, typically from about 6.5 feet (roughly 2 meters) above the soil surface to about 3 feet (1 meter) or more below it (Sharitz, 2003; Kirkman and others, 2012). Figure G-3 shows an example of standing water in a Carolina bay. Water levels are generally higher in winter and early spring when evapotranspiration is low and precipitation is moderate, and gradually decline through the summer and fall, with the exception of late-summer storm events (Sharitz, 2003; Kirkman and others, 2012). Hydroperiod is highly variable, spatially and temporally, because it is influenced by regional climate and localized weather patterns as well as by site-specific factors such as the degree of hydrologic isolation, basin morphology, and characteristics of the surrounding landscape (Battaglia and Collins, 2006). Soil physical and chemical properties likely also play an important role. Barton and others (2008) examined a suite of soil properties and found that exchangeable acidity, total nitrogen, and total carbon were the best predictors of hydroperiod in unrestored Carolina bays, and noted a strong positive correlation $(\mathrm{P}<0.05)$ between clay content of the argillic horizon of reference bays and their hydroperiod.

Hydroperiod generally covaries with other environmental characteristics, including $\mathrm{pH}$, dissolved oxygen, dissolved solids, and canopy coverage (and thus shading and water temperature), so the interactive effects of hydroperiod on biological outcomes may be direct or indirect because they mediate a suite of other variables (Sharitz and Gibbons, 1982; Fairchild and others, 2003). In Carolina bay communities, hydroperiod and water-depth fluctuation are major determinants of vegetation composition, interacting with other factors such as soil disturbance, fire history, and lifehistory traits of individual species (De Steven and Toner, 2004; Battaglia and Collins, 2006; Kirkman and others, 2012). The exceptional species richness of some community types, such as pond cypress savannas in clay-based Carolina bays, is thought to be maintained largely by a disturbance regime characterized by widely fluctuating and unpredictable hydrologic conditions - such that plants must endure both prolonged inundation and drought - which exclude mesic or upland species that might otherwise reduce species richness through competitive displacement (Kirkman and Sharitz, 1994; Sutter and Kral, 1994).

In addition, fire during dry periods can be an important component of the disturbance regime, with effects on geochemistry and vegetation structure (Kirkman, 1995). Figure G-4 shows an example of burned pocosin vegetation at Pocosin Lakes National Wildlife Refuge in North Carolina. Under appropriate conditions, peat thickness gradually increases over time in the absence of fire but (depending on fire intensity) can be dramatically reduced by burning, a process that increases $\mathrm{pH}$ and releases nutrients for plant use (Schalles and others, 1989). Fire frequency and intensity can influence canopy composition in forested Carolina bays (Sutter and Kral, 1994) and are positively associated with plant-species richness in graminoid-dominated communities (Kirkman, 1995). Natural fire regimes, however, may be substantially altered by human activity. Even for sites managed by controlled burn programs, fire during drought periods may be restricted due to safety considerations (Stroh and others, 2008). 


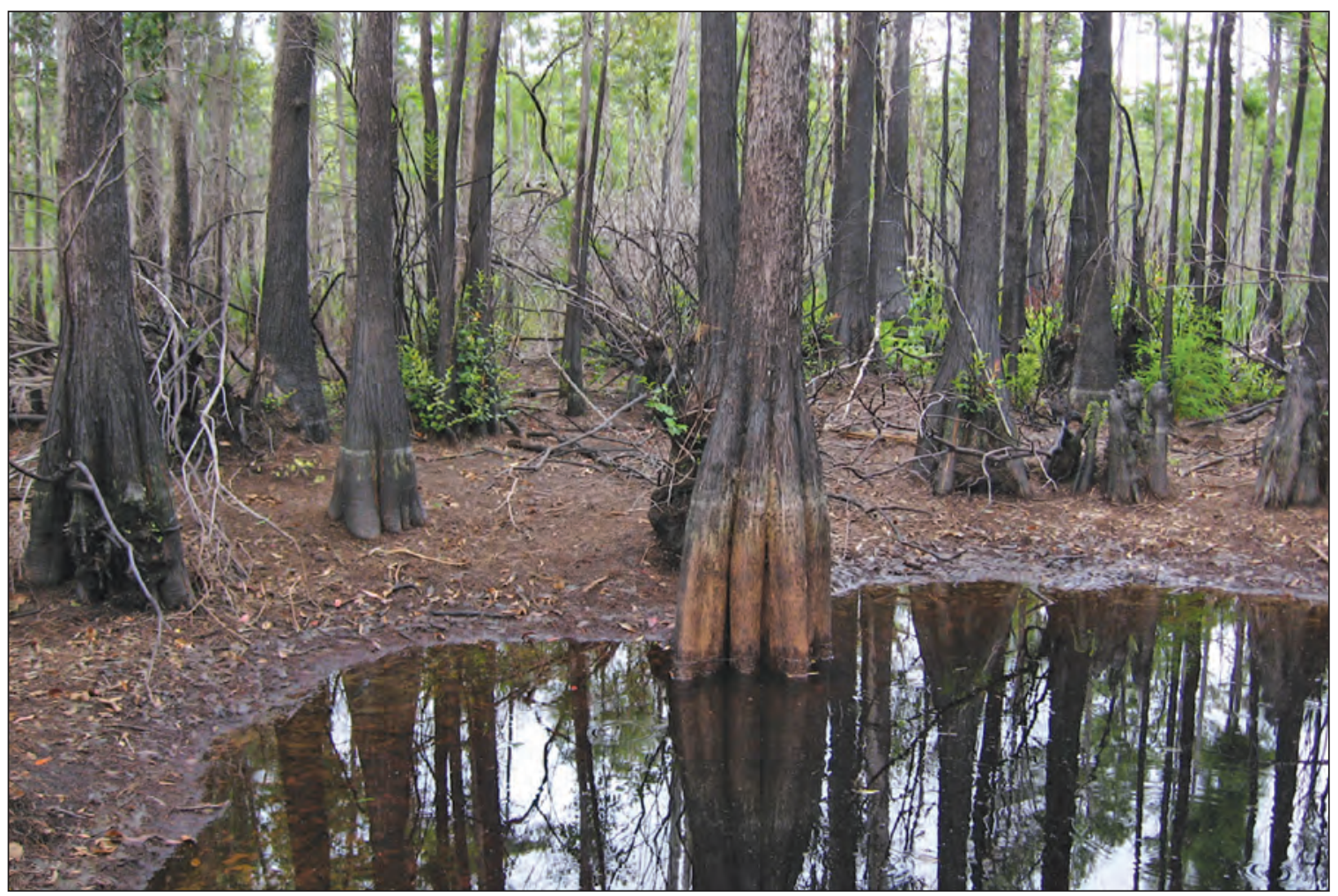

Figure G-3. A Carolina bay at Francis Marion National Forest, South Carolina. Photograph by Linda Lee, Savannah River Ecology Laboratory.

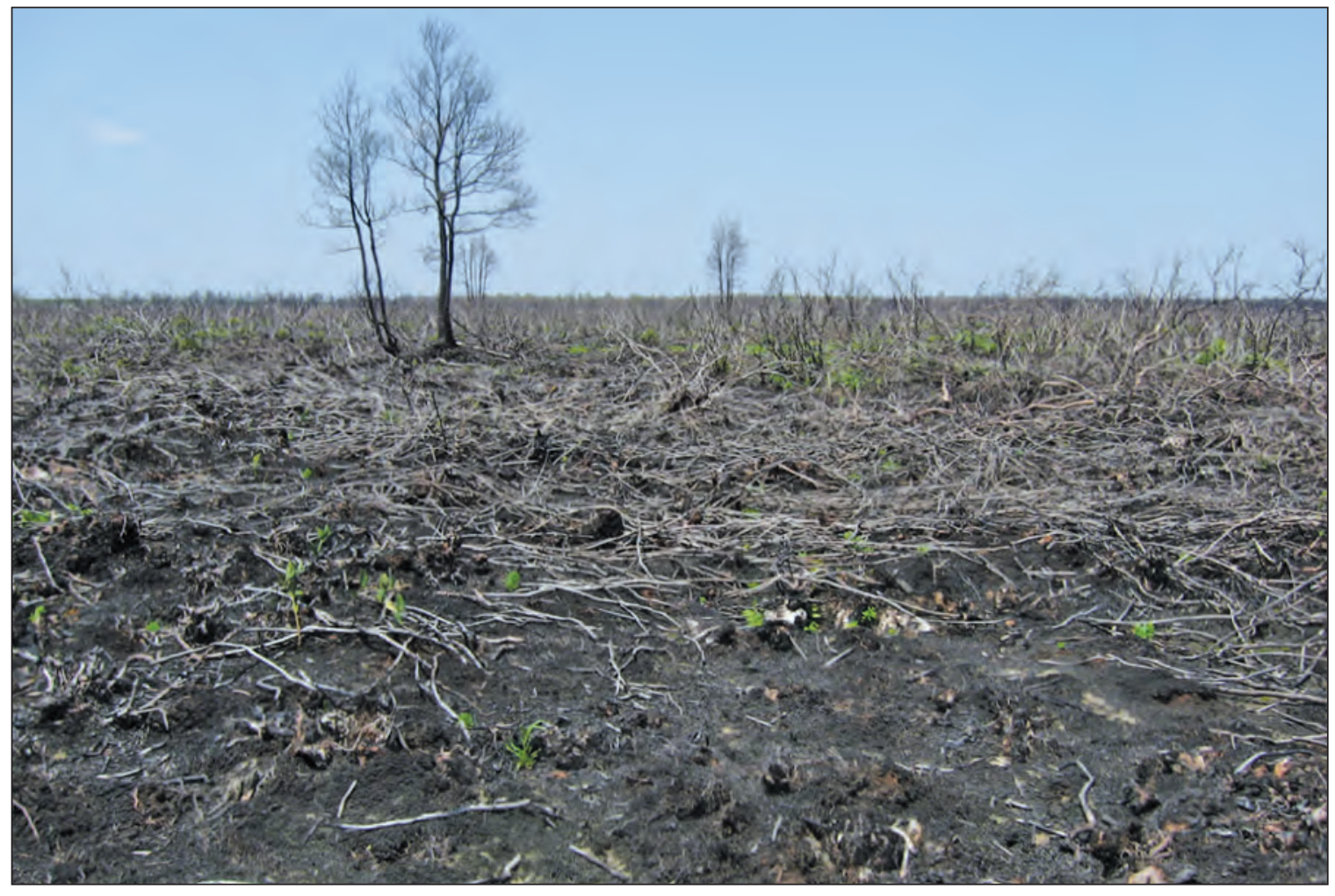

Figure G-4. Burned pocosin vegetation, Pocosin Lakes National Wildlife Refuge, North Carolina. Photograph by Linda Lee, Savannah River Ecology Laboratory. 


\section{Community Types and Vegetation Dynamics}

Like other nonalluvial wetlands of the Atlantic Coastal Plain, Carolina bays contribute to regional biodiversity by providing habitat diversity caused by heterogeneity among bays of different depression sizes, hydroperiods, and yearly patterns of inundation, as well as temporal and spatial heterogeneity of hydrologic conditions within any given bay (Sharitz, 2003). A variety of vegetation communities exist within Carolina bays (figs. G-5 through G-7), with considerable overlap of species and mosaics and (or) gradients existing between community types. As a result of these gradients, and of vegetation dynamics whereby one community may convert to another through directional or cyclical succession patterns, various investigations and reviews have suggested differing categorization schemes for Carolina bay communities (Schafale and Weakley, 1990; Tyndall and others, 1990; Bennett and Nelson, 1991).

Depending on subsurface topography and stratigraphy, some Carolina bays can support aquatic communities. Lakes and small depression ponds are inundated at their centers, may have organic or mineral soils, and often support concentric zones of vegetation along hydrologic gradients from obligate aquatics (such as Nymphaea odorata) nearest the centers to emergent herbaceous vegetation (such as Leersia hexandra) and shrubs at the upland margins (Bennett and Nelson, 1991; Nifong, 1998; Sharitz, 2003; De Steven and Toner, 2004; Schafale, 2012). Large, natural, open-water lakes supporting aquatic species are relatively rare across the geographic range of Carolina bays (Bennett and Nelson, 1991).

Carolina bays support a number of distinctive and species-rich herbaceous communities with relatively open canopies (Kirkman and others, 2012). Vernal pools are seasonally inundated with relatively short hydroperiods, support sparse-to-dense herbaceous vegetation that is intolerant of longer hydroperiods, and may be subject to fire when dry (Sharitz, 2003; Schafale, 2012). Pond-cypress savannas, an exceptionally floristically diverse community type associated with but not limited to Carolina bays, have 6- to 9-month hydroperiods, mineral soils with little to no peat underlain by a clay hardpan, and a fire frequency interval of greater than 20 years (Sutter and Kral, 1994). The canopy of pond cypress savannas is dominated by Taxodium ascendens, Nyssa biflora, Acer rubrum, Diospyros virginiana, and (or) Persea palustris,

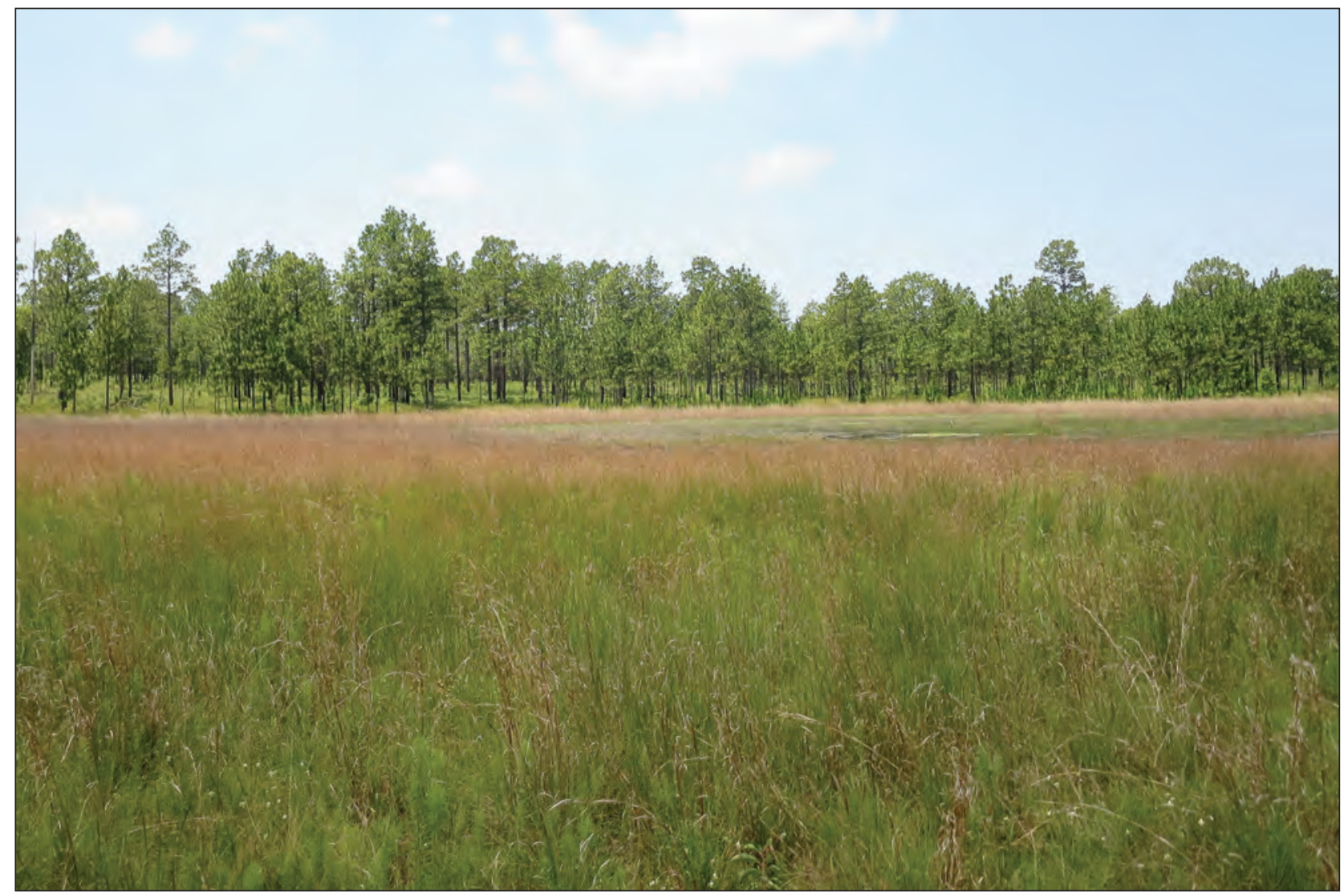

Figure G-5. Seventeen Frog Pond, Scotland County, North Carolina. Photograph by Lisa Kelly, University of North Carolina at Pembroke. 


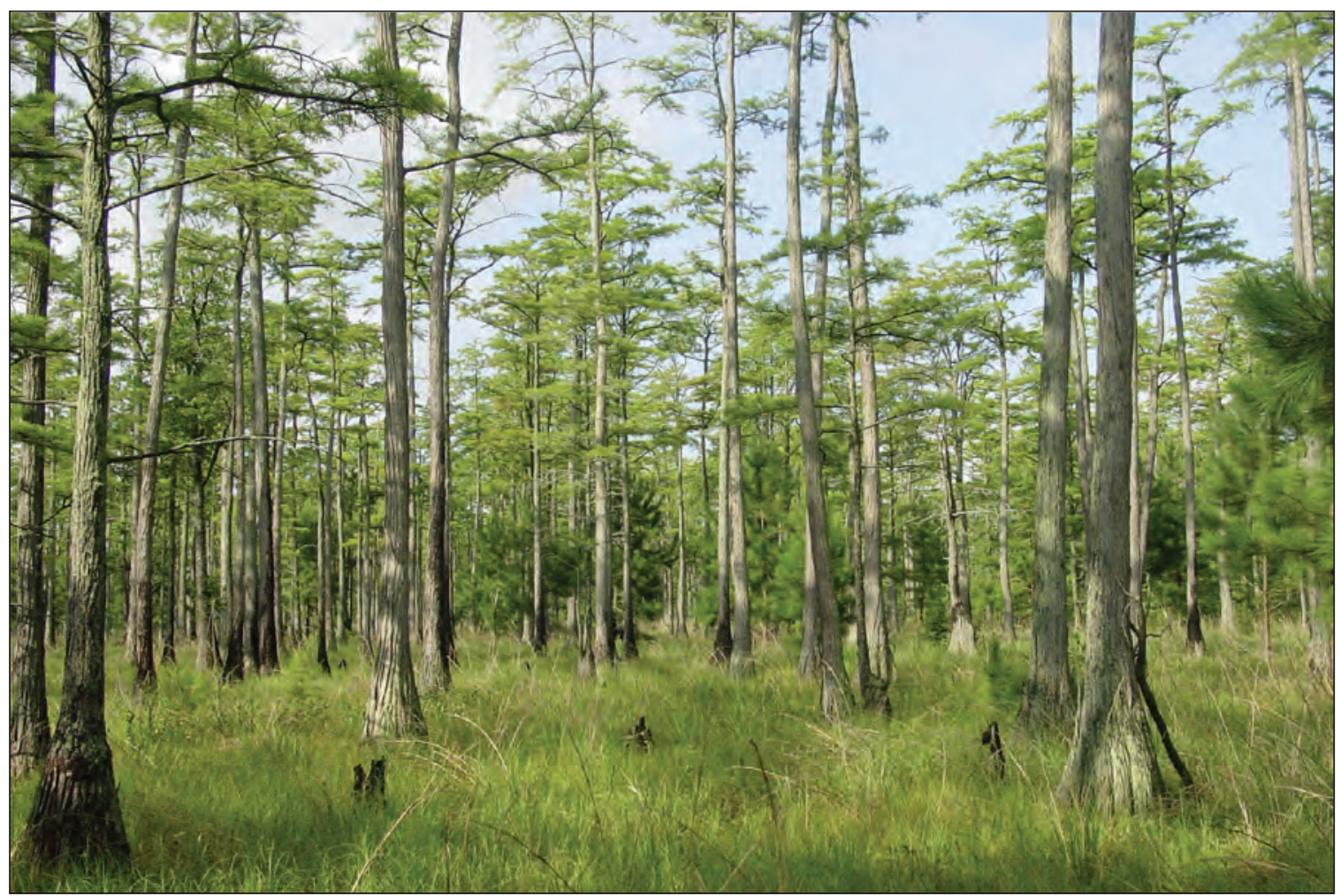

Figure G-6. Antioch Bay, Hoke County, North Carolina. Photograph by Lisa Kelly, University of North Carolina at Pembroke.

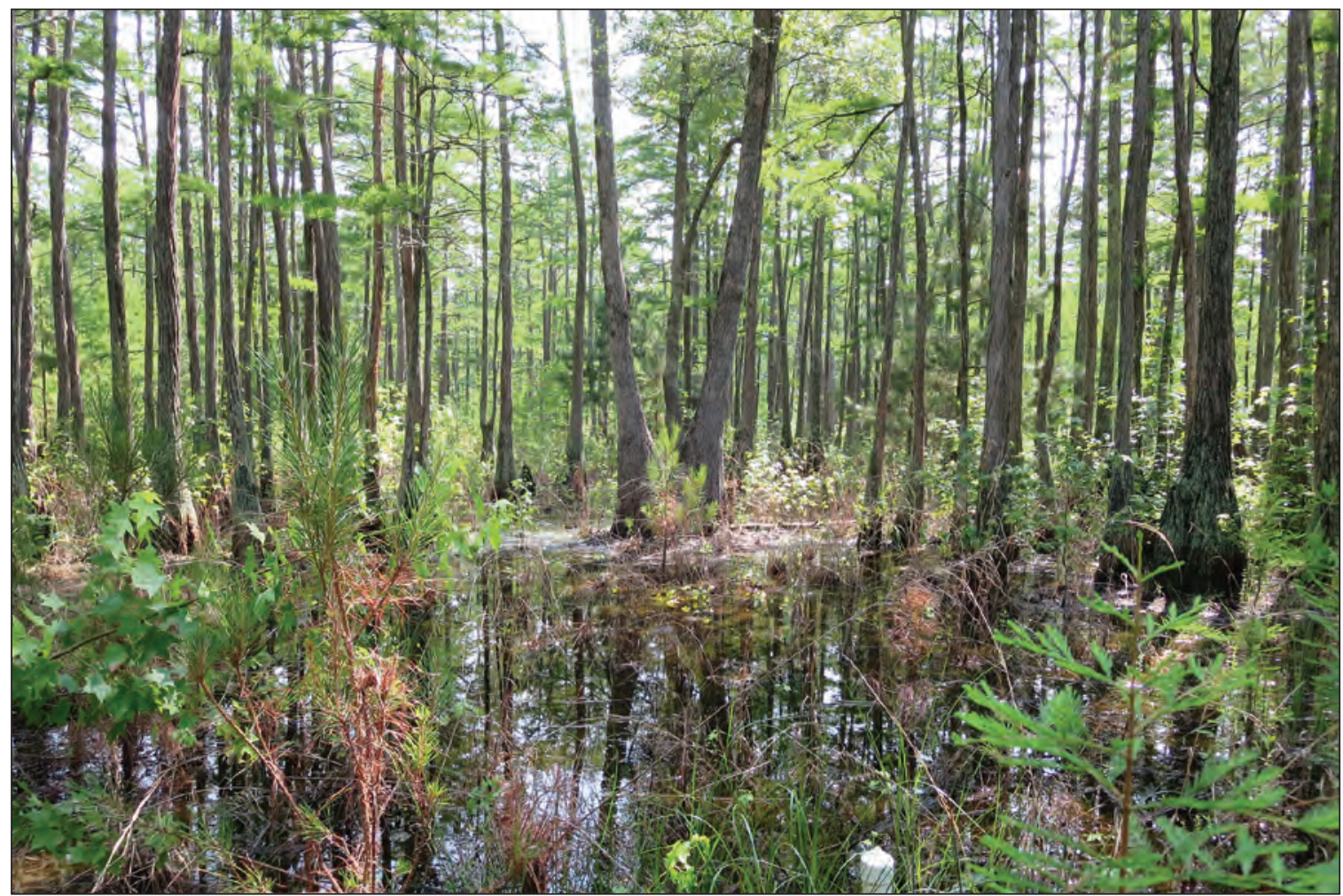

Figure G-7. Hamby's Bay, Hoke County, North Carolina. Photograph by Lisa Kelly, University of North Carolina at Pembroke. 
with an herbaceous understory rich in sedges, grasses, Juncus spp., and wetland herbs (Sutter and Kral, 1994). Pond-cypress savannas support many species of conservation concern, including Rhexia aristosa, Lobelia boykinii, Litsea aestivalis, Stillingia aquatica, Helenium pinnatifidum, Rhynchospora inundata, and Oxypolis canbyi (Bennett and Nelson, 1991). Depression meadows - which are floristically similar to pondcypress savannas but with a greater forb component and lower grass and sedge richness-also support a number of species of concern, including Rhexia aristosa, Hypericum adpressum, Echinodorus tenellus, Eleocharis robbinsii, Ludwigia glandulosa, Coreopsis rosea, Ptilimnium nodosum, Sagittaria isoetiformis, and Amphicarpum species (Bennett and Nelson, 1991; De Steven and Toner, 2004).

Forest and woodland communities are present in Carolina bays across a range of hydrologic regimes. Pondcypress ponds are characterized by a canopy of pond cypress (T. ascendens) with a mixed shrub and herbaceous understory. They are semipermanently flooded and thus distinguishable from cypress savannas, which are seasonally dry (Bennett and Nelson, 1991; Sharitz, 2003). Non-alluvial swamps are forest communities characterized by obligate wetland trees - with a mixture of Taxodium species, pond pine (Pinus serotina), and broad-leaved trees in the canopy - and are closely related to pond-cypress ponds but with typically shorter hydroperiods and greater species diversity (Bennett and Nelson, 1991; Sharitz, 2003; De Steven and Toner, 2004). Pond-pine woodlands, commonly associated with temporarily flooded and peat-filled Carolina bays, are characterized by a canopy of pond pine with a dense and tall layer of evergreen and semi-evergreen shrubs (Bennett and Nelson, 1991; Sharitz, 2003; Schafale, 2012). Atlantic white-cedar forests may be located on hydrologically isolated sites or on stream heads, are intermittently or seasonally saturated, and are dominated by Chamaecyparis thyoides in the canopy (Schafale, 2012). In the absence of fire, succession in pond pine woodlands and Atlantic white-cedar forests in peaty Carolina bays can produce bay forests that are dominated by bay species with a contingent of pond pine (Bennett and Nelson, 1991; Schafale, 2012).

Oak-hickory forests can form an ecotone between outer sand rims of Carolina bays and wet interiors (Bennett and Nelson, 1991). When these forests are disturbed by fire or timber cutting, they commonly succeed to mesic "regrowth" communities dominated by sweetgum (Liquidambar styraciflua) and other facultative wetland species (De Steven and Toner, 2004). Carolina bays with sand rims commonly support xeric sandhill scrub communities on excessively drained and infertile sites, which are floristically similar to sandhill communities along the Fall Line - dominated by longleaf pine (Pinus palustris) with a scrub layer of predominantly turkey oak (Quercus laevis) — and are maintained in part by disturbance from fire (Bennett and Nelson, 1991; Schafale, 2012).

Pocosin vegetation (fig. G-8) is characterized by very dense evergreen and deciduous shrub communities, often including Ilex and ericaceous species, with a relatively open or absent canopy and a limited herbaceous component (Bennett and Nelson, 1991; Christensen, 2000; Ross, 2003). Drier zones with shallower peat deposits and higher phosphorous availability support higher-stature vegetation ("high pocosins") than do wet, phosphorous-limited, thick peat zones that may include peat accumulations elevated above the surrounding landscape ("low pocosins") (Bennett and Nelson, 1991; Richardson, 1991; Schafale, 2012). Shrub-bog and pocosin vegetation typically are present in Carolina bays with peat and (or) sandy soils and with relatively long hydroperiods and ombrotrophic conditions (Kirkman and others, 2012; Richardson, 2012). These conditions are more common in the Middle and Outer Coastal Plain than in the Inner Coastal Plain (Bennett and Nelson, 1991; Richardson, 1991; Nifong, 1998).

Historically, the terms "Carolina bay" and "pocosin" have been used interchangeably (Thom, 1970; Bennett and Nelson, 1991; Richardson and Gibbons, 1993). Carolina bays and pocosins are distinct entities, however, despite similarities in geographic range, low nutrient levels, and the presence of shrub-bog communities (Sharitz and Gibbons, 1982). Figure G-9, adapted from similar figures by Richardson and Gibbons (1993) and Ross (2003), illustrates the relationship between Carolina bays and pocosins. Whereas all pocosins are palustrine wetlands dominated by shrub vegetation or forest, such that pocosins may be considered a sub-class of shrub-bogs or of forested wetlands, Carolina bays as a class contain a number of other community types apart from pocosin vegetation, including open-water habitats with little vegetative cover that could be classified as lacustrine wetlands (Sharitz and Gibbons, 1982; Richardson and Gibbons, 1993). Some individual Carolina bays are entirely dominated by pocosin vegetation and have pocosin soil characteristics - for example, Jerome Bog described by Buell (1946) — whereas in other Carolina bays, pocosin vegetation may be limited or entirely absent. Pocosin communities as defined by their vegetation also are present in other contexts lacking the distinct geomorphology of Carolina bays (Richardson and Gibbons, 1993).

Vegetation dynamics in Carolina bays include directional succession as well as cyclical patterns that maintain relatively stable community structures (Kirkman and others, 1996; De Steven and Toner, 2004; Stroh and others, 2008; Kirkman and others, 2012). The disturbance regime components regulating vegetation dynamics are complex and interactive. Invasion of predominantly herbaceous wetland communities by upland woody species is facilitated by dry conditions (including multi-year droughts and short hydroperiods) in the absence of fire, and is typically impeded by fire and (or) flooding (Kirkman and others, 2000; Stroh and others, 2008). Some Carolina bays experience cyclical succession patterns, with periodic inundation, droughts, and fires maintaining sub-climax conditions over long time periods and with limited inorganic filling maintaining relatively constant basin morphology (Schalles and others, 1989). With such cyclical dynamics, aquatic and emergent herbaceous species are 


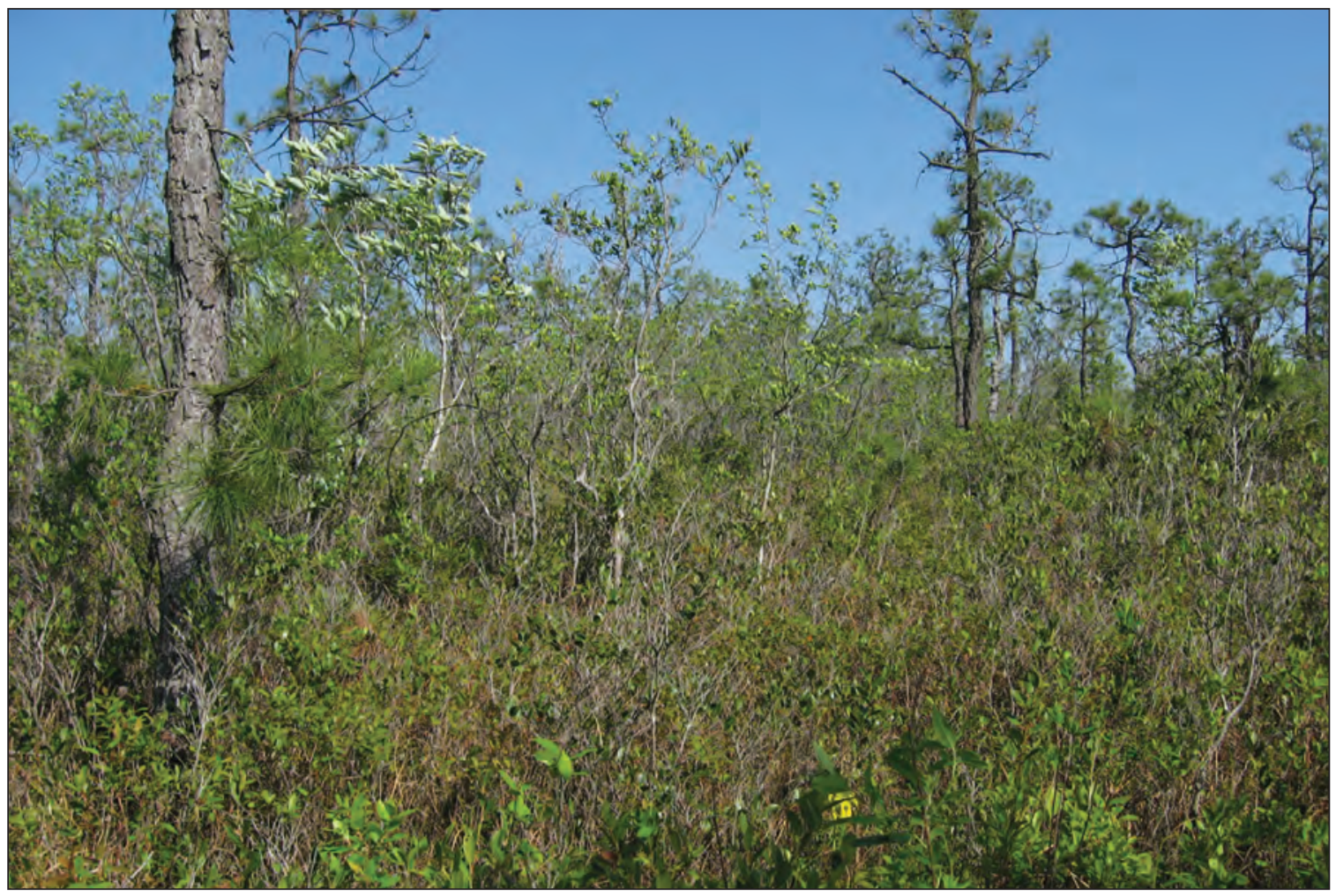

Figure G-8. Pocosin vegetation, Pocosin Lakes National Wildlife Refuge, North Carolina. Photograph by Linda Lee, Savannah River Ecology Laboratory.

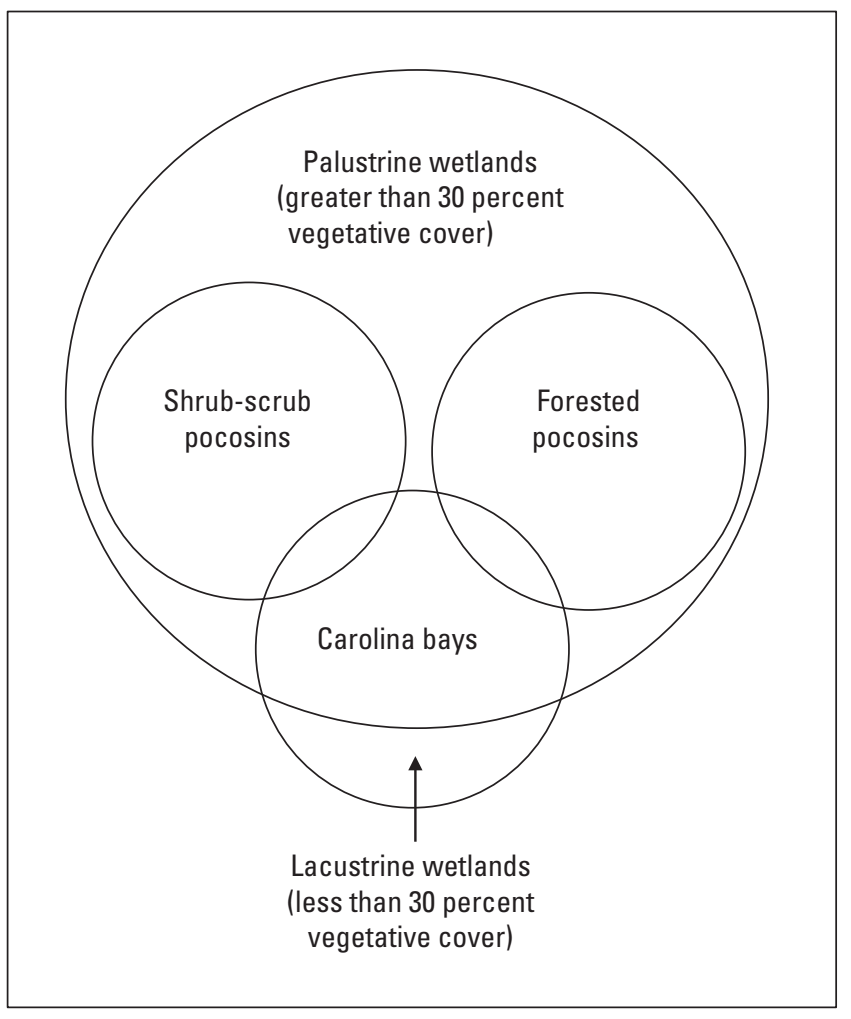

Figure G-9. Relationship between Carolina bays and pocosins, adapted from Richardson and Gibbons (1993) and Ross (2003). favored during wet periods, and flood-intolerant upland and woody species may invade during droughts (Kirkman, 1995; Stroh and others, 2008). For Carolina bays with concentric zones of vegetation along xeric-to-hydric gradients, from exterior sand rims to inundated centers (Sharitz and Gibbons, 1982; Schalles and others, 1989; Tyndall and others, 1990), zonation may shift in response to water-level changes and disturbance events through local extinction and recolonization processes (Edwards and Weakley, 2001; Sharitz, 2003). In such cases, a particular assemblage of species at a particular time represents a subset of the overall diversity possible (based on seed-bank diversity), rather than a seral stage of directional succession (Sharitz and Gibbons, 1982). Some Carolina bay taxa, including some of conservation concern, are adapted to a disturbance regime characterized by widely fluctuating and unpredictable hydrologic conditions via the maintenance of persistent seed banks from which recruitment can occur following disturbance events and when hydrologic conditions are favorable (Kirkman and Sharitz, 1994; Sutter and Kral, 1994; Sharitz, 2003; Battaglia and Collins, 2006). This type of disturbance adaptation can produce substantial inter-annual variation in above-ground species composition that is associated with hydrologic conditions, as well as seedbank diversity that is higher than above-ground diversity such that rare taxa may be present in the seed bank but absent in the vegetation (Kirkman and Sharitz, 1994; Sutter and Kral, 1994; Poiani and Dixon, 1995). 
In other cases, short hydroperiod or the presence of flood-tolerant hardwoods enables directional succession of herbaceous communities to forest (Kirkman, 1995; De Steven and Toner, 2004; Stroh and others, 2008). Hardwood establishment can accelerate the succession process by increasing overall transpiration, resulting in shortened hydroperiod (Sun and others, 2001; Stroh and others, 2008). Fire exclusion and other changes to historical fire regimes may also promote succession from herbaceous communities to mesic hardwood forest in relatively dry sites (De Steven and Toner, 2004). Pocosin vegetation may be subject to directional succession, but competing theories exist as to whether fire regime or paludification-associated nutrient limitation is the predominant successional control, with corresponding ambiguity as to the prevailing sequence of seral stages (Otte, 1981; Richardson, 2012).

Several interacting influences likely determine the relative stability of community type and composition in Carolina bays. For example, pocosin successional patterns are likely highly dependent on the interactions of site-specific conditions, including peat depth, fire regime, hydroperiod, and species composition of surrounding community types (Christensen, 2000). Experimental results from propagule banks of sediment cores suggest that hydrologic control over vegetation composition is highest at the wettest end of the hydrologic gradient — which exhibited reduced species richness with community composition converging on more homogenous assemblages of obligate wetland species - and decreases under drier conditions more favorable to the inclusion of facultative wetland and upland species (Collins and Battaglia, 2001; Battaglia and Collins, 2006). In one study of Carolina bay vegetation dynamics over the course of a multi-year drought, Mulhouse and others (2005) found that vegetation communities dominated by less robust, small-statured species were more susceptible to changes in community composition than those dominated by more robust clonal species. Additionally, land-use change and anthropogenic hydrologic alteration can substantially influence succession trajectories, although separation of these effects from those of geomorphology and topographic position may be impossible in some cases (Kirkman and others, 1996).

\section{Contributions to Regional Biodiversity}

Along with other non-alluvial wetlands in the Atlantic Coastal Plain, Carolina bays are important to regional biodiversity. Carolina bays (1) are the predominant source of lentic habitat for a large geographic area of the southeastern Coastal Plain, (2) are one of the most important natural breeding sites for amphibians in the region, (3) support extraordinarily high invertebrate richness, and (4) contain threatened and taxa-rich wetland communities such as pondcypress savannas (Sharitz and Gibbons, 1982; Pechmann and others, 1989; Schalles and others, 1989; Sutter and Kral, 1994; Taylor and others, 1999).

\section{Endemic and Biogeographically Disjunct Plant Taxa}

The exact number of rare, threatened, or endemic species in Carolina bays is not known, largely because several of the more extensive inventories and studies of rare plants, including Sutter and Kral (1994) and Edwards and Weakley (2001), have focused on broadly defined "depression wetlands" of the Coastal Plain rather than differentiating Carolina bays from other depression wetland types such as karst depressions. However, a general pattern emerges from floristic surveys that Carolina bays provide important habitat for a number of plant taxa of conservation concern (table 3-6 in appendix 3). Of these, Oxypolis canbyi (fig. G-10) can be considered a near-endemic to Carolina bays because it is endemic to wet savannas of the Atlantic Coastal Plain (Bennett and Nelson, 1991). A number of other species, such as Peltandra sagittifolia, Helenium pinnatifidum, Scleria baldwinii, and Sagittaria isoetiformis, are found in other ecosystems throughout the Coastal Plain but have been found in South Carolina only in Carolina bays; thus, at the State level, these species might be regarded as Carolina bay endemics (Bennett and Nelson, 1991). Within Carolina bays, occurrence of rare taxa appears to be concentrated within certain community types, such as pond-cypress savannas and depression meadows (Sutter and Kral, 1994; Sharitz, 2003) and possibly within certain clusters of bays. In an analysis of Carolina bays on the Delmarva Peninsula, Olivero and Zankel (2001) found that "disjunct" bay complexes nearest the coast — characterized by relatively low density of bays and geographic separation from regions of high bay density-had rare-species occurrences disproportionate to the total number of bays.

Species-level studies, both observational and experimental, have yielded insight into the physiology, life histories, and population genetics of a number of rare plants found in Carolina bays, including their particular adaptations to stress and disturbance regimes. For example, some Carolina bay plants such as Sagittaria isoetiformis are adapted to widely fluctuating hydrology and carbon dioxide levels by having the ability to switch from CAM photosynthesis when submerged to $\mathbf{C} 3$ photosynthesis when emergent (Edwards and Sharitz, 2000). Most rare species - and most plant species in generalin Carolina bays and other Coastal Plain depression wetlands are perennials, a growth strategy allowing occupation of limited space to prevent establishment of competing seedlings and the development of specialized organs for storing water and nutrients (a drought-tolerance capacity) and for gas exchange (a flood-tolerance capacity) (Edwards and Weakley, 2001). For clonally reproducing species, a further source of stress tolerance may derive from physiological connections between genets and ramets, enabling the sharing of water and nutrients and mitigating the risk for ramets as they spread into new microhabitats with unpredictable hydrologic conditions (Edwards and Weakley, 2001). Persistent seed banks are another adaptation to such conditions, offering a buffer against hydrologically induced population crashes and the resulting risk of inbreeding depression (Edwards and Weakley, 2001; Sharitz, 2003). 


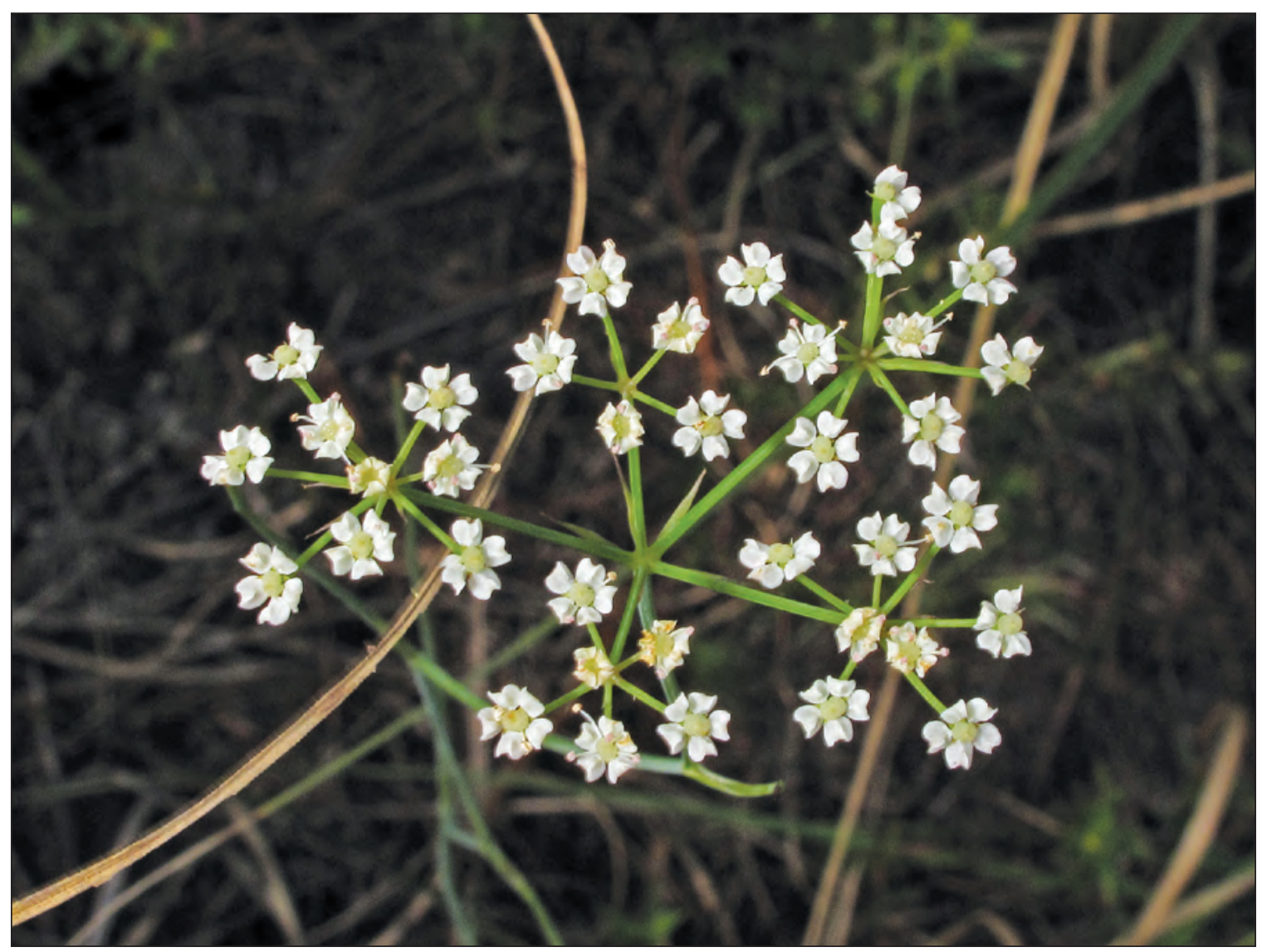

Figure G-10. Oxypolis canbyi, Lee County, Georgia. Photograph by Alan M. Cressler, U.S. Geological Survey.

\section{Animal Habitat}

Although the widely fluctuating water levels and seasonal drying of most Carolina bays render them inadequate habitat for fish, some of the largest Carolina bays are inundated at their centers and support fish populations (Sharitz and Gibbons, 1982). In a survey of 63 Carolina bays in South Carolina, Snodgrass and others (1996) found that the presence of fish was inversely related to three factors: drying frequency, the distance to other intermittent aquatic habitats, and the elevation difference with the closest permanent aquatic habitat. The presence or absence of predatory fish in a Carolina bay has important ecological effects based on trophic interactions, especially for aquatic invertebrates (Taylor and others, 1999) and amphibians (Snodgrass and others, 2000a). In Carolina bays lacking fish, odonates and salamanders are typically the dominant predators (Schalles and Shure, 1989).

Carolina bays have been documented as sites of extraordinarily high biomass, species diversity, and migration activity for amphibians (Sharitz and Gibbons, 1982). Figure G-11 shows two examples of amphibian taxa supported by Carolina bay habitat. The importance of Carolina bays to amphibian populations and to their trophic interactions extends beyond the high water line because amphibians that complete their life cycles in Carolina bays migrate annually to home ranges in surrounding terrestrial ecosystems (Pechmann and others, 1989). Hydroperiod - which is fundamentally linked to vegetation structure, water chemistry, and other important habitat characteristics - is an important factor regulating the numbers and species diversity of metamorphosing juvenile amphibians in Carolina bays (Pechmann and others, 1989). Carolina bays also provide habitat for several species of reptiles, such as aquatic turtles, snakes, and Alligator mississippiensis (American alligator) (Sharitz and Gibbons, 1982). Many bays serve as refugia for migratory waterfowl and provide forage and water for wildlife of the surrounding upland areas (Schalles and others, 1989).

During periods of drought when many smaller Carolina bays become entirely dry, larger and semipermanently inundated Carolina bays can serve as refugia for mobile species such as aquatic reptiles (Sharitz and Gibbons, 1982). Even so, reproductive output may be substantially lower during drought years depending on mobility and habitat requirements of individual species (Gibbons and others, 1983). Pechmann and others (1991) suggested that drought was largely responsible for recruitment failures for several amphibian species they studied in one Carolina bay for more than a decade, and they hypothesized that adult and larval mortality associated with breeding during dry years may have selected for amphibians capable of responding to precipitation as a predictive cue and 

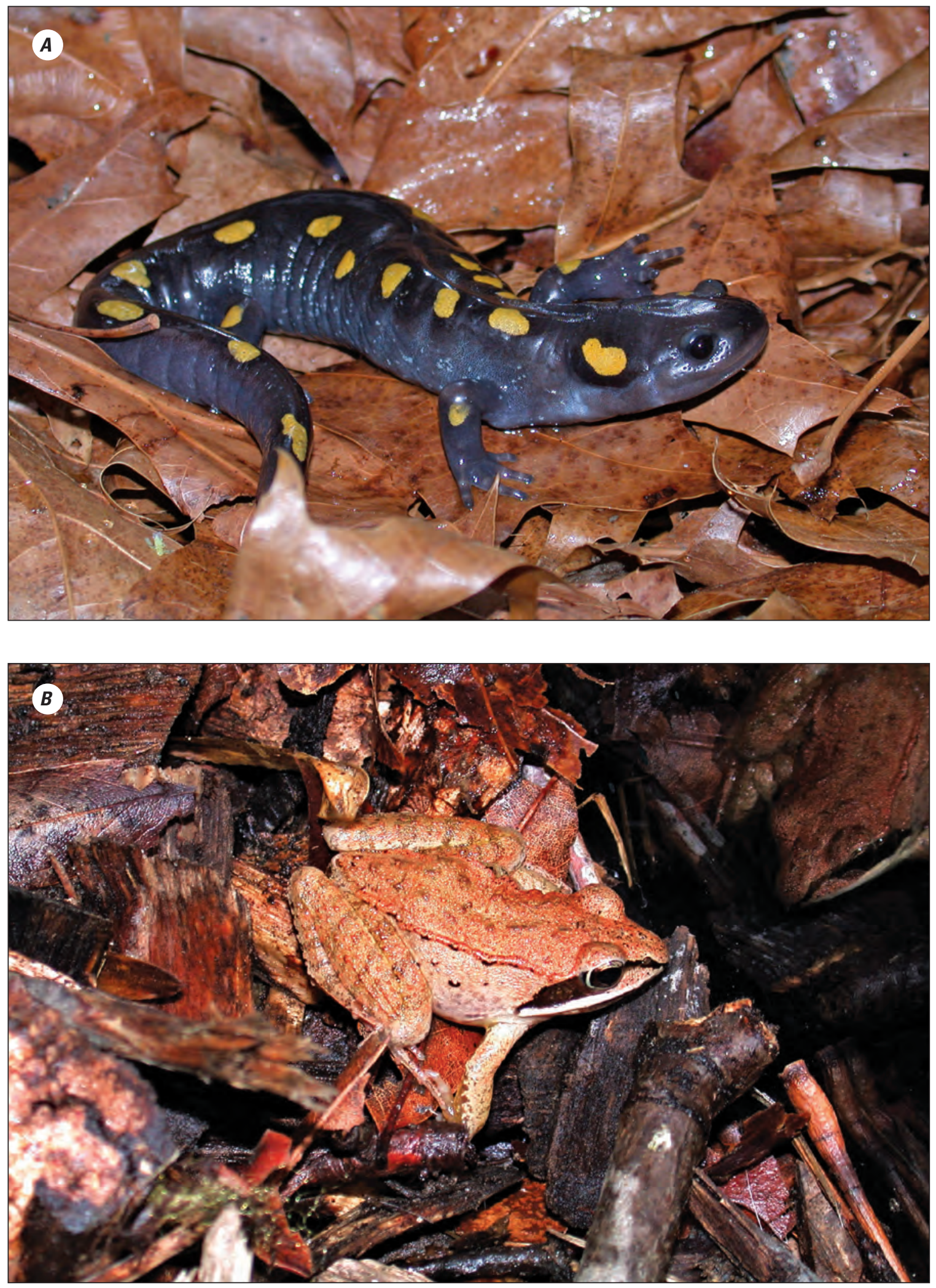

Figure G-11. Amphibian taxa supported by Carolina bay habitat: $A$, Ambystoma maculatum (spotted salamander) in a Carolina bay on the eastern shore of Maryland; $B$, Lithobates sylvaticus (wood frog) in a Carolina bay on the eastern shore of Maryland. Photographs by Joel Snodgrass, Virginia Polytechnic Institute and State University. 
reproducing only during wet years. Observing the movement of Coluber constrictor (subspecies of racers) surrounding a Carolina bay in South Carolina, Plummer and Congdon (1994) observed unexpectedly large home ranges and hypothesized that recent drought may have reduced prey availability and prompted the snakes to hunt over wider areas.

Aquatic invertebrates in Carolina bays also must cope with widely fluctuating water levels and variable hydroperiods. While some invertebrates must regularly recolonize Carolina bays following dry periods, others rely on aestivation and other mechanisms of desiccation resistance to survive dry conditions (Taylor and Mahoney, 1990; Taylor and others, 1999; Dietz-Brantley and others, 2002). Comparison of assemblages of aquatic and semiaquatic insects between Carolina bays and temporary ponds outside the Coastal Plain suggests that Carolina bays may support unusually high levels of insect species richness, especially for chironomids (Leeper and Taylor, 1998). Individual bays commonly support more than 100 species, with some cases of more than 300 species collected from a single bay (Taylor and others, 1999). Carolina bays also appear to have an extraordinarily high diversity of crustaceans compared to other temporary ponds, including cladocerans, other branchiopods, and calanoid copepods (Mahoney and others, 1990; Taylor and others, 1999). At least one copepod species, newly described by DeBiase and Taylor (1997), is believed to be endemic to Carolina bays. Most crustaceans are small-less than 0.15 inch (about 4 millimeters) in length - and are considered permanent residents, surviving dry periods through dormancy or by the production of resting eggs (Taylor and others, 1999). Other ubiquitous aquatic invertebrates in Carolina bays include annelids, nematodes, and rotifers (Taylor and others, 1999).

Invertebrate community structures in Carolina bays are regulated by a number of biotic and abiotic factors. Insect assemblages are often dominated by species adapted to the geochemistry of their habitat, including low $\mathrm{pH}$, low dissolvedoxygen concentrations, and widely fluctuating hydrologic conditions (Leeper and Taylor, 1998). Relative scarcity of mollusks in Carolina bays is believed to result from calcium limitation (Schalles and Shure, 1989). The composition of aquatic invertebrate communities in Carolina bays is highly dynamic in response to fluctuating hydrology - as water levels rise, some species emerge from their resting stages sooner than others (Taylor and Mahoney, 1990). Aquatic invertebrate populations also show strong association with vegetation types, such that particular plant communities tend to support particular assemblages of aquatic invertebrates (Schalles and Shure, 1989).

\section{Conservation Considerations}

As described in this section, Carolina bays have been subjected to anthropogenic degradation of various kinds for decades. Kirkman and others (2012) asserted that Carolina bays and other southeastern depression wetlands have been "greatly undervalued, particularly in regard to the important habitats they provide." Increasingly, the importance of these ecosystems has been recognized, prompting efforts to restore their hydrologic and ecological function (Barton and others, 2008; De Steven and others, 2010).

\section{Threats to Ecosystem Integrity}

Although no consensus exists on current or historical numbers of Carolina bays, the general agreement is that many, if not most, have been heavily damaged, contributing to overall loss of palustrine wetlands in the Coastal Plain (Dahl, 1999). Large-scale surveys of Carolina bays have concluded that previous estimates of the total number of bays were too high and that most of the existing bays had been dramatically altered by human activity (South Carolina Department of Natural Resources, 1999). Based on a survey of several thousand Carolina bays in South Carolina in the 1980s, Bennett and Nelson (1991) determined that 97 percent of bays showed some evidence of human alteration (including ditches, roads, farm ponds, development, logging, tree plantations, and row cropping), with half of all bays having at least 20 percent of their area damaged. They found this destruction to be especially pronounced for Carolina bays in the Inner Coastal Plain.

Many human activities have produced visible destruction and degradation of Carolina bays. Ditching has been a widespread and severe form of alteration, with many Carolina bays having been drained to enable conversion to agriculture (Sharitz and Gibbons, 1982; Dahl, 1999). Sand rims and associated xeric sandhill scrub communities have also been damaged by road construction, pine logging, and sand quarrying (Bennett and Nelson, 1991). Agricultural and forestry practices in upland areas surrounding Carolina bays can also degrade bay vegetation composition and ecosystem integrity. For example, Poiani and Dixon (1995) demonstrated that proximity to clear cuts was positively associated with the proportion of weedy species present in Carolina bay seed banks.

Other less readily visible processes threaten the ecological integrity of Carolina bays, such as the bioaccumulation of mercury. Despite the lack of any obvious anthropogenic or geologic sources of mercury, several characteristics of Carolina bays may exacerbate mercury methylation and bioaccumulation, including fluctuating water levels, high dissolved organic carbon content, and low $\mathrm{pH}$ (Brant and others, 2002; Unrine and others, 2005). Unrine and others (2005) observed bioaccumulated mercury concentrations in amphibian larvae within the range at which adverse effects (development problems and metamorphic failure) had been observed in laboratory studies. Evidence also exists for dietary mercury exposure from Carolina bay fish as a potential threat to sensitive piscivorous birds, including the wood stork (Mycteria americana), a federally listed species (Snodgrass and others, 2000b; Brant and others, 2002). 


\section{Conservation Strategies}

By the early 1980s, conservation officials had begun to recognize the need to inventory, study, monitor, and protect Carolina bays based on the paucity of scientific information on these ecosystems combined with mounting evidence of their ongoing destruction (Sharitz and Gibbons, 1982; Bennett and Nelson, 1991). Protected lands now sheltering Carolina bays, owned either by state parks or by the Nature Conservancy, include Woods Bay State Park and Cathedral Bay Heritage Preserve in South Carolina; Bladen Lake State Forest, Bushy Lake State Natural Area, Jones Lake State Park, and the McIntire Bay complex in North Carolina; Millington Wildlife Management Area in Maryland (Sharitz, 2003); and the Blackbird State Forest in northern Delaware (Fairchild and others, 2003). One of the most highly studied clusters of Carolina bays is on the Savannah River Site, a nuclear reservation owned and managed by the U.S. Department of Energy, which is located within a region of high Carolina bay density and which contains approximately 200 intact bays (De Steven and Toner, 2004).

Although most of the well-studied sites are on protected land, it is likely that the majority of Carolina bays throughout the range of the ecosystem are not. On the Delmarva Peninsula, for example, less than 14 percent of all Carolina bays and less than 30 percent of associated rare biodiversity elements are on protected land (Olivero and Zankel, 2001). Recent changes in U.S. Federal and State regulatory protections for "isolated" depression wetlands have heightened threats of future anthropogenic destruction or degradation of Carolina bays (Tiner, 2003a, b). Additionally, local and regional decisionmaking for Carolina bay conservation may contradict scientific evidence. In general, large and semipermanently inundated Carolina bays are more likely to be protected than smaller "dry-end" Carolina bays, with the assumptions that small wetlands support fewer species and that these species are subsets of the larger set of species found in larger wetlands, despite empirical evidence on amphibian communities contradicting both assumptions (Snodgrass and others, 2000c; Sharitz, 2003). Indeed, highly variable species diversity and community structure between Carolina bays suggests that conservation strategies predicated on protecting only a limited number of "representative" bays will fail to conserve the full suite of biodiversity (Taylor and others, 1999).

Many projects have attempted to restore individual Carolina bays or clusters of bays to their previous ecological states. Hydrologic restoration efforts often include the disruption of artificial drainage mechanisms (such as by plugging ditches), allowing examinations of the resulting hydroperiod changes and the associated effects on plant and animal communities (Dietz and others, 2001; De Steven and others, 2006, 2010). In addition to hydrologic restoration, conservation efforts may require prescribed burning or other forms of soil disturbance, as well as the control of dominant competitors (Kirkman and Sharitz, 1994). Because Carolina bays naturally support gradients and matrices of community types determined by many interactive abiotic and biotic factors, restoration projects must take into account sitespecific information such as basin size, soil type, thickness of organic soil layers, nutrient (especially phosphorous) levels, disturbance history, topographic position on the landscape, surrounding land use, hydroperiod, and ponding depth (De Steven and Toner, 2004; Vepraskas and others, 2007; De Steven and others, 2010). "Passive" restoration approaches - relying on seed-bank recruitment and natural dispersal following hydrologic restoration and the removal of upland forest vegetation - may offer low-cost alternatives to active seeding or planting, but they may not fully establish the characteristic assemblages found in reference bays (De Steven and others, 2006), requiring supplemental transplantation of selected species (De Steven and Sharitz, 2007).

Evaluation of restoration projects in Carolina bays typically requires long-term monitoring. If hydroperiod change or hydroperiod comparison of restored bays to reference bays is used as an evaluation standard, then long periods of pre-restoration and post-restoration data are required because of the high degree of spatial and temporal variability in hydroperiod, which is common to Carolina bays (Barton and others, 2008). Hydrologic restoration can be hampered by regional droughts (De Steven and others, 2006; 2010) and by regional hydrologic alteration (Vepraskas and others, 2007). Even when hydrologic restoration is apparently successful based on hydroperiod similarity between restored and reference bays, ecological restoration can be complicated by lingering effects of previous agricultural use, such as altered soil physical properties as well as high $\mathrm{pH}$ and nutrient levels from lime and fertilizer applications (Bruland and others, 2003; Vepraskas and others, 2007). Other factors such as seed-bank persistence and variable germination ability necessitate long-term monitoring of rare plant populations (Edwards and Weakley, 2001).

\section{Knowledge Gaps}

Although Carolina bays are a relatively well-studied ecosystem, a number of knowledge gaps persist. For example, additional research is warranted on floristic diversity of Carolina bays. Persistent seed banks and corresponding high levels of inter-annual variation in community composition render one-time floristic inventories insufficient to capture the true diversity of Carolina bay plant communities, necessitating multi-year studies to compare seed-bank to above-ground vegetation diversity (Sutter and Kral, 1994). Although seed-bank dynamics may be critical to the survival of certain rare plant populations (Sharitz, 2003), little is known about the seed banks for many rare species. For example, only about 20 percent of the depression-wetland rare-plant species listed by Edwards and Weakley (2001) had seed-bank information available.

Microbial autotrophs, including algae and purple photosynthetic bacteria, constitute an important but littlestudied component of Carolina bay communities. Purple 
photosynthetic bacteria may play a role in nitrogen fixation and in acidification resulting from sulfuric acid production (Schalles and Shure, 1989). Based on the construction of 16S rRNA gene libraries from sediments of one Carolina bay, Wise and others (1997) found a high level of microbial diversity with numerous sequences unrepresented in existing databases, suggesting a strong prevalence of novel, undescribed microbial species. The microbial ecology of Carolina bays deserves further study, including trophic relationships and food-web dynamics.

Additionally, the drivers and ecological effects of hydroperiod dynamics need further empirical study. The interaction between Carolina bay surface water and groundwater, only recently accepted as an important hydrologic feature of these ecosystems, is still not fully understood (Schalles and Shure, 1989; Lide, 1995; Pyzoha and others, 2008). Soil physical and chemical properties appear to be related to hydroperiod response in Carolina bays (for example, argillic horizon clay content is positively associated with hydroperiod); however, the exact nature of these relationships has not been quantified at large scales (Barton and others, 2008). Although hydroperiod is a known factor determining vegetation expression from seed banks, the strength of this relationship is not known, making it difficult to predict the magnitude and type of community restructuring resulting from hydrologic changes (Battaglia and Collins, 2006). Understanding this relationship will be critical for future conservation efforts in the face of changing hydrologic conditions, including those that might result from regional climate change. Other important conservation needs include the quantification of upland land area surrounding Carolina bays necessary to maintain water quality, hydrologic integrity, and habitat for migrating animal species (Sutter and Kral, 1994), and the determination of appropriate evaluation metrics for Carolina bay restoration projects (De Steven and others, 2010).

\section{Possible Ecological Effects From Climate Change}

Although several studies have alluded to climate change as a possible factor affecting Carolina bays, systematic analyses are lacking in the scientific literature regarding the potential current and future effects from climate change on Carolina bay hydrology and ecological outcomes. In a recent review of the literature on southeastern depression wetlands, Kirkman and others (2012) mentioned briefly that regional changes in precipitation timing and magnitude would likely affect hydroperiod and, in turn, ecological outcomes, but did not elaborate further. Mulhouse and others (2005) and Stroh and others (2008) assessed vegetation change in response to short-term climatic variability (multi-year droughts and drought/re-flooding cycles) but not long-term directional climate change. Similarly, Sun and others (2006) used a modeling approach based on short-term climate variability (a wet period and multi-year drought) to predict the direction of groundwater/surface-water interactions resulting from precipitation inputs and noted that climate change would likely affect hydroperiod through such interactions, but did not offer specific long-term projections based on climate-change scenarios.

In the absence of systematic, empirical research on the ecological effects of long-term directional climate change, hypotheses can be formulated based on current knowledge of the factors governing vegetation structure and faunal habitat in Carolina bays. Given the well-documented importance of hydroperiod to community structure for plants (Sharitz and Gibbons, 1982; Sutter and Kral, 1994; Sun and others, 2001; De Steven and Toner, 2004; Battaglia and Collins, 2006; Stroh and others, 2008; Kirkman and others, 2012) and for animals and their trophic interactions (Pechmann and others, 1989; Snodgrass and others, 1996; Fairchild and others, 2003), hydroperiod alteration is likely to be a key mechanism by which climate change induces ecological shifts in Carolina bays. Paleoecological investigations may offer some evidence of how previous climatic shifts have been associated with hydrologic and vegetation changes (Whitehead, 1964). For example, based on micropetrographic analysis of peat cores from a Carolina bay showing a large number of thin peat layers reflecting alternating wet and dry periods, Cohen and others (1999) inferred that biotic responses in that wetland had been highly sensitive to hydrologic and climatic changes over time. Comparing these results to those from other peatlands in the southeastern United States with larger areal extents, such as the Everglades in Florida and Okefenokee Swamp in Georgia, Cohen and others (1999) inferred that the small size of Carolina bay wetlands might make them especially sensitive to vegetation shifts in response to climatic fluctuations.

Over the long term, if hydroperiods shorten on average or if droughts become more common or severe, ecological consequences might resemble the effects of artificial drainage, possibly including directional succession of rare and speciesrich herbaceous wetland communities to forests. Drought intensification would also be expected to degrade habitat for aquatic reptiles (Gibbons and others, 1983) and amphibians (Pechmann and others, 1991). Conversely, climate-changeinduced reductions in drought frequency or intensity might adversely affect Carolina bay plant taxa whose recruitment from the seed bank is dependent on drought-related disturbance (Kirkman and Sharitz, 1994). Empirical evidence suggests that aquatic habitat in Carolina bays supports reduced plant-species richness compared to zones of frequent fluctuation in water level (Collins and Battaglia, 2001). If so, then hydroperiod lengthening as a result of climate change could conceivably reduce plant-species richness if zones currently subjected to frequent drying shift toward semipermanent inundation. At this point in time, such hypotheses are largely speculative. To test such hypotheses about climate-changedriven ecological outcomes, empirical studies are needed to quantify the effects of precipitation and temperature changes in terms of hydroperiod alteration and to link this hydroperiod alteration to long-term change in community structures. 


\section{References}

Barton, C., Andrews, D., and Kolka, R., 2008, Evaluating hydroperiod response in restored Carolina bay wetlands using soil physicochemical properties: Restoration Ecology, v. 16 , no. 4, p. 668-677.

Battaglia, L., and Collins, B., 2006, Linking hydroperiod and vegetation response in Carolina bay wetlands: Plant Ecology, v. 184, no. 1, p. 173-185.

Bennett, S., and Nelson, J., 1991, Distribution and status of Carolina bays in South Carolina: Columbia, S.C., South Carolina Wildlife and Marine Resources Department, Nongame and Heritage Trust Publications.

Brant, H., Jagoe, C., Snodgrass, J., Bryan, A., and Gariboldi, J., 2002, Potential risk to wood storks (Mycteria americana) from mercury in Carolina bay fish: Environmental Pollution, v. 120 , p. 405-413.

Bruland, G., Hanchey, M., and Richardson, C., 2003, Effects of agriculture and wetland restoration on hydrology, soils, and water quality of a Carolina bay complex: Wetlands Ecology and Management, v. 11, p. 141-156.

Buell, M., 1946, Jerome Bog, a peat-filled "Carolina bay": Bulletin of the Torrey Botanical Club, v. 73, no. 1, p. 24-33.

Christensen, N., 2000, Vegetation of the southeastern Coastal Plain, in Barbour, M., and Billings, W., eds., North American terrestrial vegetation: New York, N.Y., Cambridge University Press, p. 397-448.

Cohen, A., Gage, C., Moore, W., and VanPelt, R., 1999, Combining organic petrography and palynology to assess anthropogenic impacts on peatlands, part 2-An example from a Carolina bay wetland at the Savannah River Site in South Carolina: International Journal of Coal Geology, v. 39, p. 47-95.

Collins, B., and Battaglia, L., 2001, Hydrology effects on propagule bank expression and vegetation in six Carolina bays: Community Ecology, v. 2, no. 1, p. 21-33.

Dahl, T., 1999, South Carolina's wetlands status and trends, 1982-1989: Washington, D.C., U.S. Department of the Interior, Fish and Wildlife Service.

DeBiase, A., and Taylor, B., 1997, Aglaodiaptomus atomicus, a new species (Crustacea: Copepoda: Calanoida: Diaptomidae) from freshwater wetland ponds in South Carolina, USA, and a redescription of $A$. saskatchewanensis (Wilson 1958): Proceedings of the Biological Society of Washington, v. 110, no. 4, p. 569-580.
De Steven, D., and Sharitz, R., 2007, Transplanting native dominant plants to facilitate community development in restored Coastal Plain wetlands: Wetlands, v. 27, no. 4, p. 972-978.

De Steven, D., Sharitz, R., and Barton, C., 2010, Ecological outcomes and evaluation of success in passively restored southeastern depressional wetlands: Wetlands, v. 30, no. 6 , p. 1129-1140.

De Steven, D., Sharitz, R., Singer, J., and Barton, C., 2006, Testing a passive revegetation approach for restoring coastal plain depression wetlands: Restoration Ecology, v. 14, no. 3, p. $452-460$.

De Steven, D., and Toner, M., 2004, Vegetation of upper coastal plain depression wetlands-Environmental templates and wetland dynamics within a landscape framework: Wetlands, v. 24, no. 1, p. 23-42.

Dietz, S., Batzer, D., Taylor, B., and DeBiase, A., 2001, Invertebrate communities of twenty ditched Carolina bay wetlands scheduled for restoration, in Proceedings of the 2001 Georgia Water Resources Conference: Athens, Ga., p. 321-324.

Dietz-Brantley, S., Taylor, B., Batzer, D., and DeBiase, A., 2002, Invertebrates that aestivate in dry basins of Carolina bay wetlands: Wetlands, v. 22, no. 4, p. 767-775.

Edwards, A., and Sharitz, R., 2000, Population genetics of two rare perennials in isolated wetlands: Sagittaria isoetiformis and $S$. teres (Alismataceae): American Journal of Botany, v. 87 , no. 8 , p. 1147-1158.

Edwards, A., and Weakley, A., 2001, Population biology and management of rare plants in depression wetlands of the southeastern coastal plain, USA: Natural Areas Journal, v. 21 , no. 1 , p. 12-35.

Ewing, J., 2003, Characterization of soils in a drained Carolina Bay wetland prior to restoration: Raleigh, N.C., North Carolina State University, Masters Thesis.

Fairchild, G., Cruz, J., Faulds, A., Short, A., and Matta, J., 2003, Microhabitat and landscape influences on aquatic beetle assemblages in a cluster of temporary and permanent ponds: Journal of the North American Benthological Society, v. 22, no. 2, p. 224-240.

Fenneman, N., and Johnson, D., 1946, Physical divisions of the United States: U.S. Geological Survey map prepared in cooperation with the Physiographic Commission, scale $1: 7,000,000$

Folkerts, G., 1997, Citronelle ponds-Little-known wetlands of the central Gulf Coastal Plain, USA: Natural Areas Journal, v. 17, p. 6-16. 
Gibbons, J., Greene, J., and Congdon, J., 1983, Droughtrelated responses of aquatic turtle populations: Journal of Herpetology, v. 17, no. 3, p. 242-246.

Kirkman, L., 1995, Impacts of fire and hydrological regimes on vegetation in depression wetlands of southeastern USA, in Cerulean, S., and Engstrom, R., eds., Fire in wetlandsA management perspective, Proceedings of the Tall Timbers Fire Ecology Conference, No. 19: Tall Timbers Research Station, Tallahassee, Fla., p. 10-20.

Kirkman, L.K., Goebel, P.C., West, L., Drew, M.B., and Palik, B.J., 2000, Depressional wetland vegetation typesA question of plant community development: Wetlands, v. 20, no. 2, p. 373-385.

Kirkman, L., Lide, R., Wein, G., and Sharitz, R., 1996, Vegetation changes and land-use legacies of depression wetlands of the western Coastal Plain of South Carolina1951-1992: Wetlands, v. 16, no. 4, p. 564-576.

Kirkman, L., and Sharitz, R., 1994, Vegetation disturbance and maintenance of diversity in intermittently flooded Carolina bays in South Carolina: Ecological Applications, v. 4, no. 1, p. 177-188.

Kirkman, L., Smith, L., and Golladay, S., 2012, Southeastern depressional wetlands, in Batzer, D., and Baldwinl, A., eds., Wetland habitats of North America-Ecology and conservation concerns: Berkeley, Calif., University of California Press, p. 203-215.

Leeper, D., and Taylor, B., 1998, Insect emergence from a South Carolina (USA) temporary wetland pond, with emphasis on the Chironomidae (Diptera): Journal of the North American Benthological Society, v. 17, no. 1, p. 54-72.

Lide, R., 1995, Hydrology of a Carolina bay located on the upper Coastal Plain of western South Carolina: Wetlands, v. 15 , no. 1, p. $47-57$.

Lide, R., 1997, When is a depression wetland a Carolina bay?: Southeastern Geographer, v. 37, p. 90-98.

Mahoney, D., Mort, M., and Taylor, B., 1990, Species richness of calanoid copepods, cladocerans and other branchiopods in Carolina bay temporary ponds: American Midland Naturalist, v. 123 , no. 2 , p. 244-258.

Mulhouse, J., De Steven, D., Lide, R., and Sharitz, R., 2005, Effects of dominant species on vegetation change in Carolina bay wetlands following a multi-year drought: The Journal of the Torrey Botanical Society, v. 132, no. 3, p. $411-420$.

Newman, M., and Schalles, J., 1990, The water chemistry of Carolina bays - A regional survey: Stuttgart, Archiv für Hydrobiologie, v. 118, no. 2, p. 147-168.
Nifong, T., 1998, An ecosystematic analysis of Carolina bays in the coastal plain of the Carolinas: Chapel Hill, N.C., University of North Carolina, Ph.D. dissertation.

Olivero, A., and Zankel, M., 2001, Delmarva bay density analysis: The Nature Conservancy, accessed April 8, 2015, at http://gis.tnc.org/data/MapbookWebsite/map_page. php?map_id=11.

Otte, L., 1981, Origin, development, and maintenance of pocosin wetlands of North Carolina. Report to the North Carolina Natural Heritage Program: Raleigh, N.C., North Carolina Department of Natural Resources and Community Development.

Pechmann, J., Scott, D., Gibbons, J., and Semlitsch, R., 1989, Influence of wetland hydroperiod on diversity and abundance of metamorphosing juvenile amphibians: Wetlands Ecology and Management, v. 1, no. 1, p. 3-11.

Pechmann, J., Scott, D., Semlitsch, R., Caldwell, J., Vitt, L., and Gibbons, J., 1991, Declining amphibian populationsThe problem of separating human impacts from natural fluctuations: Science, v. 253, p. 892-895.

Phillips, P., and Shedlock, R., 1993, Hydrology and chemistry of groundwater and seasonal ponds in the Atlantic Coastal Plain in Delaware, USA: Journal of Hydrology, v. 141, p. 157-178.

Plummer, M., and Congdon, J., 1994, Radiotelemetric study of activity and movements of racers (Coluber constrictor) associated with a Carolina bay in South Carolina: Copeia, v. 1994, no. 1, p. 20-26.

Poiani, K., and Dixon, P., 1995, Seed banks of Carolina bays-Potential contributions from surrounding landscape vegetation: American Midland Naturalist, v. 134, no. 1, p. $140-154$.

Prouty, W., 1952, Carolina bays and their origin: Geological Society of America Bulletin, v. 63, p. 167-224.

Pyzoha, J., Callahan, T., Sun, G., Trettin, C., and Miwa, M., 2008, A conceptual hydrologic model for a forested Carolina bay depressional wetland on the Coastal Plain of South Carolina, USA: Hydrological Processes, v. 22, p. 2689-2698.

Richardson, C., 1991, Pocosins-An ecological perspective: Wetlands, v. 11, no. 1, p. 335-354.

Richardson, C., 2012, Pocosins-Evergreen shrub bogs of the southeast, in Batzer, D., and Baldwin, A., eds., Wetland habitats of North America-Ecology and conservation concerns: Berkeley, Calif., University of California Press, p. 189-202. 
Richardson, C., and Gibbons, J., 1993, Pocosins, Carolina bays, and mountain bogs, in Martin, W., Boyce, S., and Echternacht, A., eds., Biodiversity of the southeastern United States-Lowland terrestrial communities: New York, John Wiley and Sons, Inc., p. 257-310.

Ross, T.E., 2003, Pocosins and Carolina bays compared: The North Carolina Geographer, v. 11, p. 22-32.

Schafale, M., 2012, Guide to the natural communities of North Carolina, fourth approximation: Raleigh, N.C., North Carolina Natural Heritage Program.

Schafale, M., and Weakley, A., 1990, Classification of the natural communities of North Carolina, third approximation: Raleigh, N.C., North Carolina Natural Heritage Program.

Schalles, J., Sharitz, R., Gibbons, J., Leversee, G., and Knox, J., 1989, Carolina bays of the Savannah River plant: Aiken, S.C., Savannah River Plant National Environmental Research Park Program.

Schalles, J., and Shure, D., 1989, Hydrology, community structure, and productivity patterns of a dystrophic Carolina bay wetland: Ecological Monographs, v. 59, no. 4, p. 365-385.

Semlitsch, R., and Bodie, J., 1998, Are small, isolated wetlands expendable?: Conservation Biology, v. 12, no. 5, p. 1129-1133.

Sharitz, R., 2003, Carolina bay wetlands - Unique habitats of the southeastern United States: Wetlands, v. 23, no. 3, p. $550-562$.

Sharitz, R., and Gibbons, J., 1982, The ecology of southeastern shrub bogs (pocosins) and Carolina bays-A community profile, FWS/OBS-82/04: Washington, D.C., Department of Interior, U.S. Fish and Wildlife Service, Division of Biological Services.

Snodgrass, J., Bryan, A., and Burger, J., 2000a, Development of expectations of larval amphibian assemblage structure in southeastern depression wetlands: Ecological Applications, v. 10 , no. 4 , p. 1219-1229.

Snodgrass, J., Bryan, A., Lide, R., and Smith, G., 1996, Factors affecting the occurrence and structure of fish assemblages in isolated wetlands of the upper Coastal Plain, USA: Canadian Journal of Fisheries and Aquatic Sciences, v. 454, p. 443-454.

Snodgrass, J., Jagoe, C., Bryan, A., Brant, H., and Burger, J., 2000b, Effects of trophic status and wetland morphology, hydroperiod, and water chemistry on mercury concentrations in fish: Canadian Journal of Fisheries and Aquatic Sciences, v. 57, no. 1, p. 171-180.
Snodgrass, J., Komoroski, M., Bryan, A., and Burger, J., 2000c, Relationships among isolated wetland size, hydroperiod, and amphibian species richness-Implications for wetland regulations: Conservation Biology, v. 14, no. 2, p. 414-419.

Soller, D., and Mills, H., 1991, Surficial geology and geomorphology, in Horton, J., and Zullo, V., eds., The geology of the Carolinas: Knoxville, Tenn., University of Tennessee Press, p. 290-308.

South Carolina Department of Natural Resources, 1999, Advance identification of Carolina bays for South Carolina wetlands protection: Columbia, S.C., South Carolina Department of Natural Resources, Division of Land, Water and Conservation.

Stroh, C., De Steven, D., and Guntenspergen, G., 2008, Effect of climate fluctuations on long-term vegetation dynamics in Carolina bay wetlands: Wetlands, v. 28, no. 1, p. 17-27.

Sun, G., Callahan, T., Pyzoha, J., and Trettin, C., 2006, Modeling the climatic and subsurface stratigraphy controls on the hydrology of a Carolina bay wetland in South Carolina, USA: Wetlands, v. 26, no. 2, p. 567-580.

Sun, G., McNulty, S., Shepard, J., Amatya, D., Riekerk, H., Comerford, N., Skaggs, W., and Swift, L., 2001, Effects of timber management on the hydrology of wetland forests in the southern United States: Forest Ecology and Management, v. 143, no. 1-3, p. 227-236.

Sutter, R., and Kral, R., 1994, The ecology, status, and conservation of two non-alluvial wetland communities in the south Atlantic and eastern Gulf coastal plain, USA: Biological Conservation, v. 68, p. 235-243.

Taylor, B., Leeper, D., McClure, M., and DeBiase, A., 1999, Carolina bays - Ecology of aquatic invertebrates and perspectives on conservation, in Batzer, D., Rader, R., and Wissinger, S., eds., Invertebrates in freshwater wetlands of North America: New York, John Wiley and Sons, Inc., p. 167-196.

Taylor, B., and Mahoney, D., 1990, Zooplankton in Rainbow Bay, a Carolina bay pond-Population dynamics in a temporary habitat: Freshwater Biology, v. 24, p. 597-612.

Tesoriero, A., Spruill, T., and Eimers, J., 2004, Geochemistry of shallow ground water in coastal plain environments in the southeastern United States-Implications for aquifer susceptibility: Applied Geochemistry, v. 19, p. 1471-1482.

Thom, B., 1970, Carolina bays in Horry and Marion Counties, South Carolina: Geological Society of America Bulletin, v. 81, p. $783-814$. 
Tiner, R., 2003a, Estimated extent of geographically isolated wetlands in selected areas of the United States: Wetlands, v. 23 , no. 3 , p. 532-540.

Tiner, R.W., 2003b, Geographically isolated wetlands of the United States: Wetlands, v. 23, no. 3, p. 494-516.

Tyndall, R., McCarthy, K., Ludwig, J., and Rome, A., 1990, Vegetation of six Carolina bays in Maryland: Castanea, v. 55 , no. 1 , p. $1-21$.

Unrine, J., Jagoe, C., Brinton, A., Brant, H., and Garvin, N., 2005, Dietary mercury exposure and bioaccumulation in amphibian larvae inhabiting Carolina bay wetlands: Environmental Pollution, v. 135, no. 2, p. 245-253.

Vepraskas, M., White, J., Amoozegar, A., Hesterberg, D., Huffman, R., Skaggs, R., Gregory, J., Broome, S., Caldwell, P., Davis, K., Abit, S., Smith, H., Zelasko, A., and Brownfield, C., 2007, Methodology to assess soil, hydrologic, and site parameters that affect wetland restoration, phase 2: Raleigh, N.C., North Carolina State University.
Whitehead, D., 1964, Palynology and Pleistocene phytogeography of unglaciated eastern North America, in Wright, H., and Frey, D., eds., The Quaternary of the United States: Princeton, N.J., Princeton University Press, p. 417-432.

Willoughby, R., Howard, C.S., and Nystrom, P., 2005, Generalized geologic map of South Carolina: Columbia, S.C., South Carolina Department of Natural Resources.

Wise, M., McArthur, J., and Shimkets, L., 1997, Bacterial diversity of a Carolina bay as determined by $16 \mathrm{~S}$ rRNA gene analysis - Confirmation of novel taxa: Applied and Environmental Microbiology, v. 63, no. 4, p. 1505-1514. 



\section{Chapter H. Karst-Depression Wetlands}

\section{Introduction}

Karst depressions (sinkholes) are a landscape feature in many areas underlain by carbonate rocks (White, 1988). Sinkhole drainage patterns integrate effects of geologic structure, lithology, soil and regolith properties, and climate to produce a continuum ranging from freely and permanently drained to perennially ponded (White, 1988; Ford and Williams, 1989). Within that continuum are sinkholes whose interiors meet the scientific and jurisdictional definitions of wetlands: prolonged inundation or saturation during the growing season, obligate or facultative wetland vegetation, and hydric soils (fig. H-1; Cowardin and others, 1979). In comparison with bottomland hardwoods, coastal marshes, and similar extensive systems, karst-depression wetlands constitute a small fraction of wetland area within the southeastern United States as a whole, but they can account for a much larger percentage of total wetland area in regions underlain by carbonate bedrock (Wolfe, 1996b). Karst-depression wetlands are typically isolated from each other geographically, though not necessarily hydrologically (Hendricks and Goodwin, 1952; Wolfe, 1996a, b; Hill, 2007).

Numerous studies in the southeastern United States have shown that karst-depression wetlands contribute substantially to regional biodiversity, notably by supporting high levels of biogeographic endemism and disjunction for vascular plants and by providing habitat to reptiles, amphibians, and invertebrates (Ellis and Chester, 1989; Sutter and Kral, 1994; Buhlmann and others, 1999; Fleming and Van Alstine, 1999; Edwards and Weakley, 2001; Grant and others, 2003; Miller and others, 2005; Kirkman and others, 2012). However, many of these studies have been site-specific or focused on multiple sites in relatively close geographic proximity of one another. A literature synthesis concerning southeastern depressional wetlands (Kirkman and others, 2012) was restricted to the Coastal Plain and did not emphasize distinctions between karst and nonkarst systems.

Two classes of southeastern depression wetlands not treated in detail in this report warrant mention: Citronelle ponds and depressional mountain bogs. Folkerts (1997) described geographically isolated depression wetlands on the Citronelle Formation (Citronelle ponds) in the Eastern Gulf Coastal Plain of Mississippi, Alabama, and Florida and attributed their origins to subsidence caused by dissolution of kaolinite or iron oxide cementing materials rather than by dissolution of the deeply mantled subsurface limestone. The literature on these systems is sparse; their relationship to other geographically isolated depression wetlands of the Coastal Plain has yet to be resolved (D. De Steven, U.S. Forest Service, written commun., 2014), and their mechanisms of formation are not known

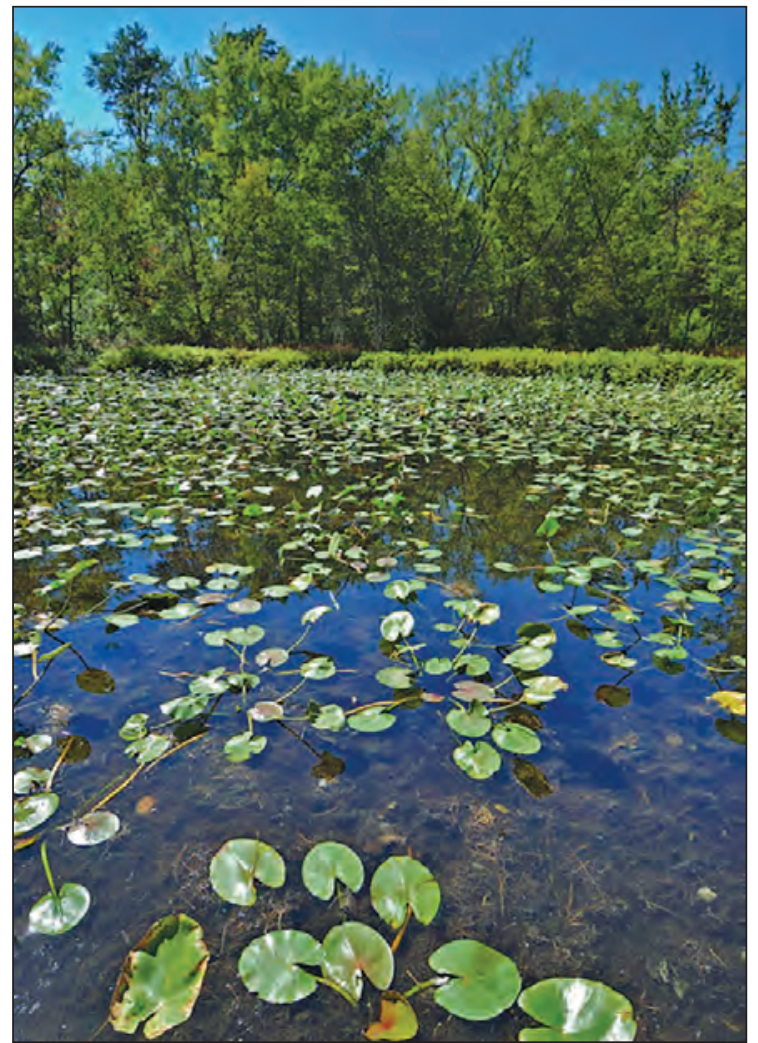

Figure H-1. Harriston Ponds, Augusta County, Virginia. Photograph by Gary Fleming, Virginia Department of Conservation and Recreation.

in sufficient detail to classify them as noncarbonate karst, pseudokarst, or nonkarst. Stronger arguments have been made for a noncarbonate karstic origin of some depressional mountain bogs of the Blue Ridge in Virginia and North Carolina where peat-derived organic acids have evidently accelerated dissolution of underlying quartzite and progressively enlarged depressions at the bedrock-regolith interface (Reed and others, 1963; Whittecar and Lawrence, 1999).

\section{Geographic Range}

Wetlands in topographic depressions are present in several karst regions of the southeastern United States. Three regions in which karst-depression wetlands have been relatively well studied include (1) the Highland Rim section of the Interior Low Plateaus Physiographic Province, especially the Eastern Highland Rim, Pennyroyal District, and Mitchell Plain subsections, (2) the Dougherty Plain ecoregion within the Coastal Plain Physiographic Province, and (3) the Valley 
and Ridge Physiographic Province, especially the Shenandoah Valley (fig. H-2). Karst-depression wetlands are distributed widely across the Highland Rim in Tennessee, Kentucky, and southern Indiana, with notable concentrations in the Mitchell Plains, Eastern Highland Rim, and Pennyroyal District (Homoya and Hedge, 1985; Ellis and Chester, 1989;
Wolfe, 1996b). The most extensively studied karst-depression wetlands in the Valley and Ridge Physiographic Province are in the Shenandoah Valley of Virginia (Buhlmann and others, 1999; Fleming and Van Alstine, 1999), but examples have also been reported from northwestern Georgia (Greear, 1967) to central Pennsylvania (O’Driscoll and Parizek, 2003). Within

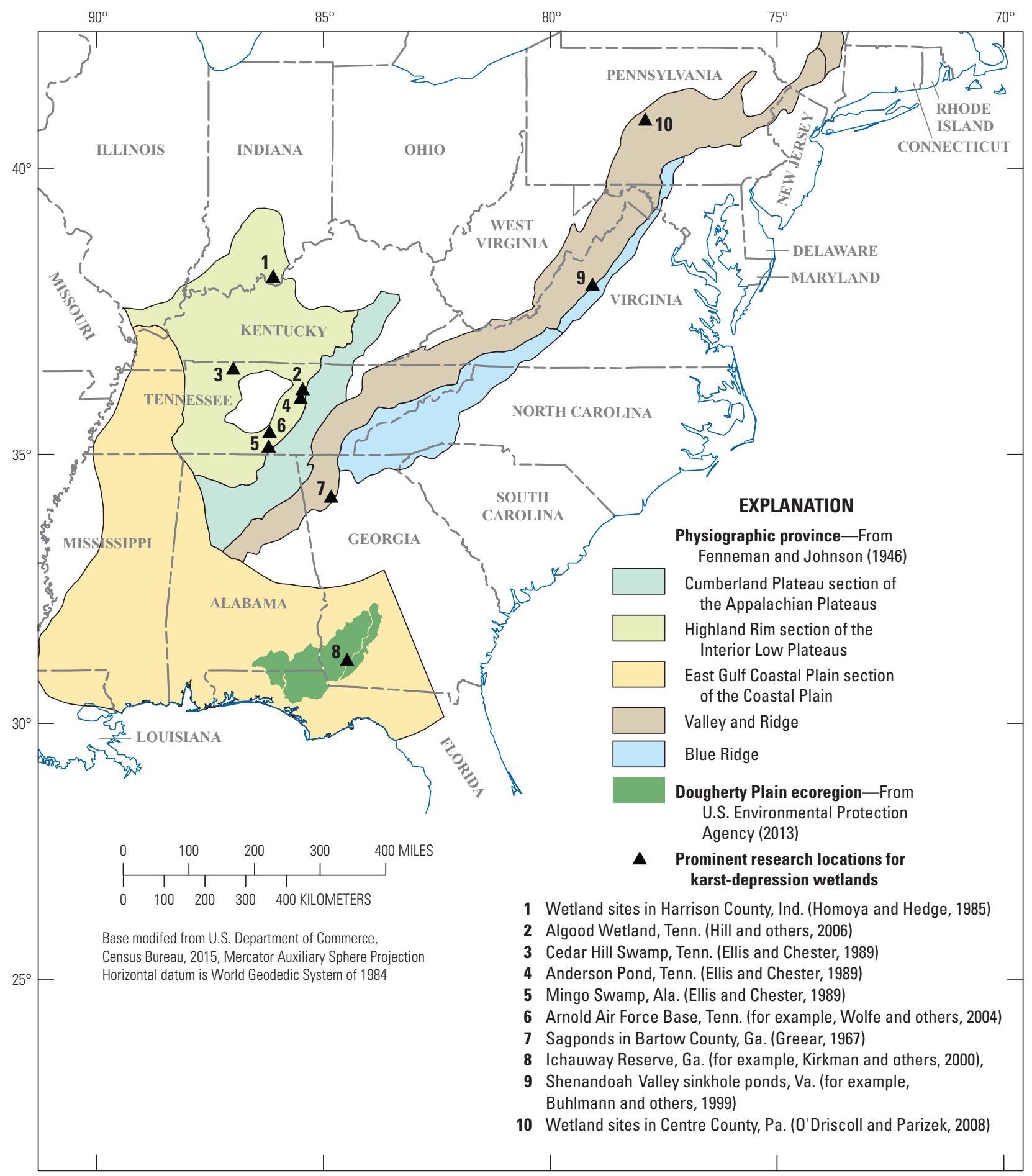

Figure H-2. General geographic distribution of selected areas containing concentrations of karst-depression wetlands in the southeastern United States. 
the East Gulf Coastal Plain of the Coastal Plain Physiographic Province, karst-depression wetlands - locally called limesinks - have been described extensively throughout the Dougherty Plain, which is a Level IV ecoregion (U.S. Environmental Protection Agency, 2013) that extends from southeastern Alabama and northwestern Florida into southwestern Georgia (Hendricks and Goodwin, 1952; Beck and Arden, 1984; Sutter and Kral, 1994; Golladay and others, 1999).

\section{Physical Geography}

In general, the development of a karst-depression wetland first requires the formation of a karst depression (sinkhole) and then requires drainage characteristics that support wetland plant communities and soils. Allowing for climatic variability, the most important determinants of sinkhole formation and drainage characteristics are geologic. In particular, the lithology, stratigraphy, and structure of underlying bedrock and the physicochemical properties and thickness of the unconsolidated cover (regolith) interact to determine the spatial character and drainage of karst features (White, 1988). Lithology largely determines each bedrock unit's susceptibility to karst formation, and stratigraphy and structure combine to determine the spatial arrangement of units that are susceptible or resistant to karst formation. Together, lithology, stratigraphy, and structure exert a major influence on groundwater gradients and on the hydraulic and storage characteristics of underlying karst aquifers (Beck and Arden, 1984; Brahana and Bradley, 1986; White, 1988; Hollyday and Hileman, 1996; Wolfe and others, 1997). The regolith mediates movement of water from the land surface to the top of rock and exerts a strong influence on local relief, notably on sinkhole depth. Impermeable regolith restricts flow from a sinkhole to underlying aquifers, whereas permeable regolith facilitates such flow (Hendricks and Goodwin, 1952; Greear, 1967; Wolfe, 1996a, b; O’Driscoll and Parizek, 2008). Thick regolith generally obscures the surface expression of some karst features and may reduce the depth of sinkholes or fill them entirely (Greear, 1967; O'Driscoll and Parizek, 2008). The "perching" of water above the water table by impermeable regolith has been reported in all areas where the hydrology of southeastern karst-depression wetlands has been quantified (Hendricks and Goodwin, 1952; Greear, 1967; Wolfe, 1996a, b; O'Driscoll and Parizek, 2008; Hill and Neary, 2012).

Commonly, a wetland's relative moisture content is expressed in terms of "hydroperiod," a word with numerous and, in some cases, inconsistent definitions (Nuttle, 1997). Despite efforts to broaden use of the term hydroperiod (for example Nuttle, 1997), the word is used here in its simplest sense: number of days in a given year that water is ponded in a given depression. The term "hydrologic regime" is used to describe broader patterns of hydrologic conditions defined by long-term variability of the timing, duration, depth, and frequency of water-level fluctuation, year to year and among different sites. The karst-depression wetlands considered here illustrate how bedrock geology and regolith influence the geomorphology and hydrology of karst-depression wetlands in three contrasting physiographic settings: the Highland Rim section of the Interior Low Plateaus Physiographic Province, the Valley and Ridge Physiographic Province, and the Dougherty Plain ecoregion of the Coastal Plain Physiographic Province (Fenneman and Johnson, 1946).

\section{The Highland Rim}

On the Highland Rim, variations in bedrock lithology are a major determinant of topography and drainage, including the distribution of karst-depression wetlands. Across most of its extent, the Highland Rim is underlain by gently dipping (typically less than 1 percent and rarely more than 2 percent gradient) Mississippian limestones overlying resistant cherts, shales, and siltstones of lower Mississippian age (Brahana and Bradley, 1986; Hess and others, 1989). Dips are generally oriented away from either of two broad regional uplift structures, the Nashville and the Jessamine (Lexington) geologic domes, whose exposed cores of karstic carbonate rocks underlie the Nashville Basin and Bluegrass Region (Lexington Plain), respectively (Fenneman, 1938; Ryder, 1987). Sinkhole development is generally strongest in areas where the limestones are thickest and most soluble, notably the sinkhole plains of the Pennyroyal Plateau (Hess and others, 1989), Eastern Highland Rim (Wolfe, 1996b), and Mitchell Plain (Unterreiner, 2006). Sinkhole development is weak or absent where the limestones are thinner and resistant cherts, shales, and siltstones approach the surface, such as along the fluvially dissected escarpment separating the Highland Rim from the Nashville Basin (Wolfe, 1996b). Areas such as The Barrens of the Eastern Highland Rim where karst development and surface drainage are somewhat weakly expressed, tend to be where karst-depression wetlands are most likely to be concentrated (Wolfe, 1996b). However, these systems, like sinkholes in general, are widely distributed across the Highland Rim (Homoya and Hedge, 1985; Ellis and Chester, 1989).

Highland Rim soils are developed from insoluble material (residuum) left from the dissolution of limestone, extensively overlain by approximately 3-6 feet (about 1-2 meters) of loess or by localized river or hillslope deposits (Love and others, 1956; Patterson, 1989). Wolfe (1996b) reported overall regolith thicknesses ranging from 23 to 108 feet (about 7 to 33 meters) in an area with numerous karst-depression wetlands. Soils in and around karstdepression wetlands in Tennessee commonly feature fragipans (layers of low hydraulic conductivity and impeded drainage), and an association between these wetlands and one soil series, the Guthrie Silt Loam, has been widely reported (Love and others, 1956; Ellis and Chester, 1989; Patterson, 1989; Wolfe, 1996b). In contrast, although Homoya and Hedge (1985) found the air-photo base of county soil maps useful in locating karst-depression wetlands in southern Indiana, 
they found only limited association between karst-depression wetlands and particular soil series and emphasized regolith thickness rather than fragipan presence as a soil correlate of karst-depression wetlands.

Where the hydrology of Highland Rim karst-depression wetlands has been examined in detail, perching of surface water by impermeable unconsolidated layers above the seasonal water table has been commonly observed (Wolfe, 1996a, b; Hill and Neary, 2007, 2012). A second mode of sinkhole inundation and drainage observed by Wolfe $(1996 \mathrm{a}, \mathrm{b})$ is direct intersection of the seasonal water table with the sinkhole bottom. Wolfe (1996a, b) noted such intersection only in the deepest depressions of the study area, which he called "compound sinks" (fig. H-3), emphasizing their coalescent geomorphic character and multiple internal drains in contrast to shallower perched "karst pans" with no visible internal drains. Compound sinks with close interactions between surface water and groundwater can experience rapid fluctuations in water levels - as much as 6 feet (about 2 meters) within 1 to 3 days - whereas water-level fluctuation in karst pans typically occurs more gradually and within a narrow range (Wolfe, 1996a, b). For compound sinks and karst pans, hydroperiods exceeding 200 days per year are common (Wolfe, 1996a, b; Wolfe and others, 2004; Hill and Neary, 2012).

In a shallow karst pan on the Eastern Highland Rim of Tennessee, Hill (2007) and Hill and Neary (2007) found surface runoff to be the dominant input to the annual water budget. Deep recharge accounted for more than half of the total outflow from this wetland despite relatively high rates of evapotranspiration during the growing season, suggesting that groundwater recharge is an important function of some karst-depression wetlands (Hill and Neary, 2012).

\section{The Valley and Ridge}

Investigations of karst-depression wetlands have been conducted in several regions of the Valley and Ridge Physiographic Province. Greear (1967) described the hydrology and ecology of karst-depression wetlands ("sagponds") along the eastern margin of the Great Valley of northwestern Georgia near the valley's boundary with the Piedmont Physiographic Province. His model of their origins and evolution emphasized progressive filling with relatively fine-grained sediment to the point of "extinction" or complete filling. For these wetlands, hydroperiod was positively related to regolith thickness within the depression and inversely related to sinkhole depth. Hydroperiod is thus presented as dynamic, growing progressively longer over time until abruptly shortened by complete filling (Greear, 1967).

O’Driscoll and Parizek $(2003,2008)$ examined drainage characteristics, hydroperiods, and groundwater/surface-water gradients in karst-depression wetlands in Centre County, Pennsylvania. Primary water inputs to these wetlands are direct precipitation and groundwater less than 20 feet (about

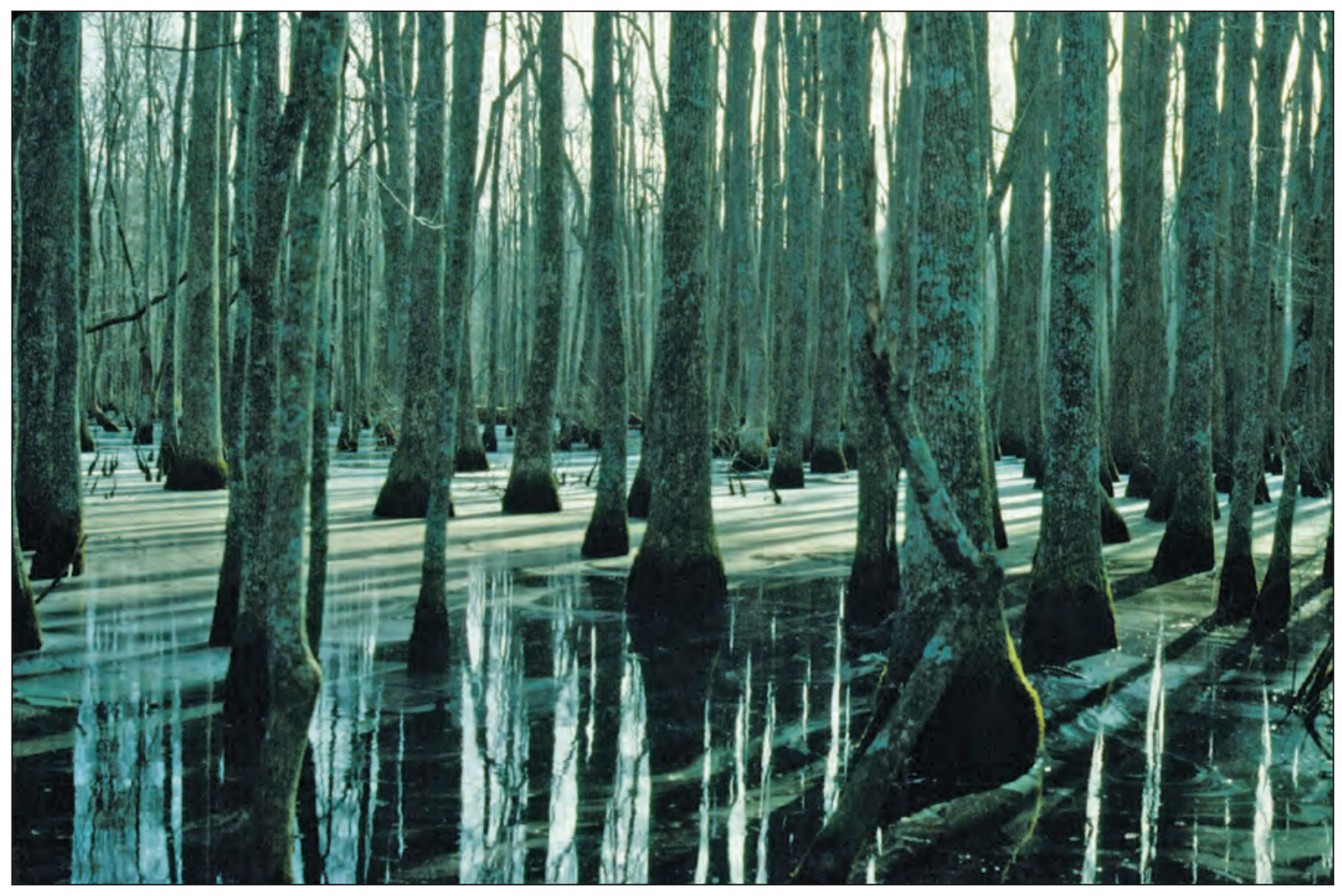

Figure H-3. Nyssa aquatica stand in Westall Swamp, Arnold Air Force Base, Coffee County, Tennessee. Photograph by William Wolfe, U.S. Geological Survey. 
6 meters) below land surface. Counterintuitively, hydroperiods were found to be longer in sinkholes with sandy unconsolidated fill than in those filled with clay. Perched water in these ponds, as well as mounding of groundwater directly below them, indicates that low-permeability zones in the regolith impede but do not prevent infiltration. In contrast to the Shenandoah Valley sinkhole ponds (Buhlmann and others, 1999) and Georgia sagponds (Greear, 1967), the unconsolidated fill in the Centre County depressions is residual rather than depositional in origin (O'Driscoll and Parizek, 2003, 2008).

One of the most distinctive groups of karst-depression wetlands within the Valley and Ridge is the Shenandoah Valley "sinkhole ponds" (figs. H-4 and H-5). Steep northeast/ southwest-trending folds and widespread faults have produced a landscape of generally parallel valleys and ridges from which the province takes its name (Fenneman, 1938). The folds and faults also juxtapose rocks of contrasting lithology in spatial arrangements far more complex than the top-tobottom stratigraphic order of the Highland Rim. Limestones, dolomite, and argillaceous carbonates underlie about one-third of the area of the Valley and Ridge (Johnson and others, 2011), but their occurrences are discontinuous and can be widely separated. Carbonate rocks, overlain with varying thicknesses of alluvium, typically form broad valley bottoms separated by ridges composed of chert-capped residuum (Hollyday and Hileman, 1996; Wolfe and others, 1997). Within the Shenandoah Valley, karst-depression wetlands are concentrated along an approximately 55-mile (roughly 89-kilometer) segment of the valley's southeastern margin, from Page County to Augusta County, Virginia, corresponding to the western toe of the Blue Ridge Physiographic Province (Buhlmann and others, 1999).

Karst-depression wetlands of the western toe of the Blue Ridge occupy a highly distinctive hydrogeologic setting that has been studied as a resource for industrial groundwater supply (Hinkle and Sterrett, 1976, 1978; Hollyday and Hileman, 1996). Folded karstic dolomites of Cambrian to Ordovician age are covered by a mantle that is generally at least 100 feet (about 30 meters) thick. This mantle generally consists of fine-grained residuum overlain by coarse, permeable stream deposits and rubble derived from the steep slopes of the Blue Ridge that developed from siliciclastic rocks, commonly quartzite. The steep, impermeable upper slopes produce large volumes of runoff, which infiltrates readily through the coarse stream deposits and rubble to recharge the underlying karst aquifers (Hinkle and Sterrett, 1976, 1978; Hollyday and Hileman, 1996). This "western toe" setting is not confined to the Shenandoah Valley but can be found in discontinuous occurrences along the eastern margin of the Valley and Ridge from Alabama to Pennsylvania (Hollyday and Hileman, 1996).

In contrast to their floristics, the hydrology of the Shenandoah Valley sinkhole ponds has received relatively limited scientific attention. Buhlmann and others (1999) assigned each of 36 wetlands to 1 of 6 hydrologic classes,

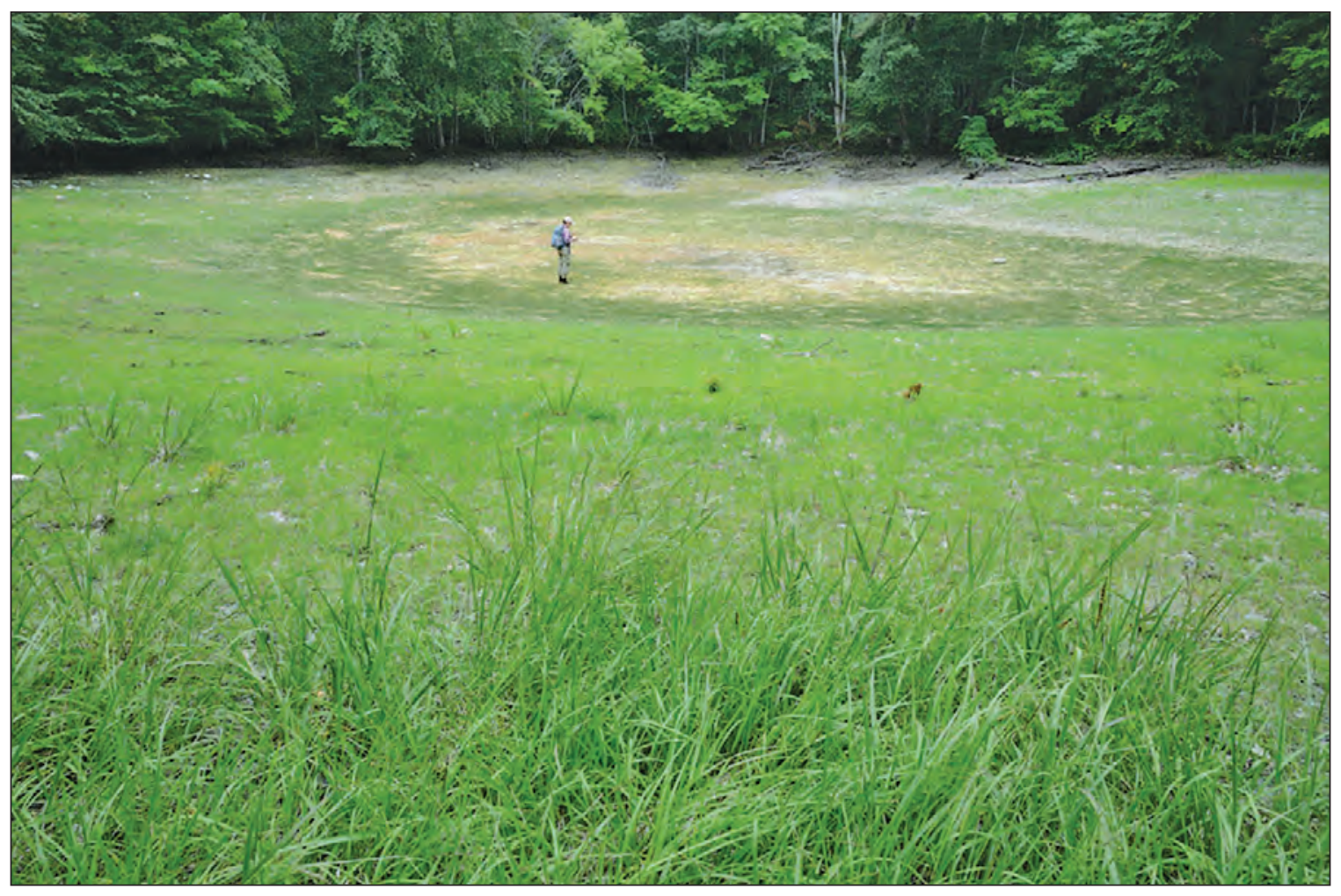

Figure H-4. Deep Pond, Maple Flats Pond Complex, Augusta County, Virginia. Photograph by Gary Fleming, Virginia Department of Conservation and Recreation. 


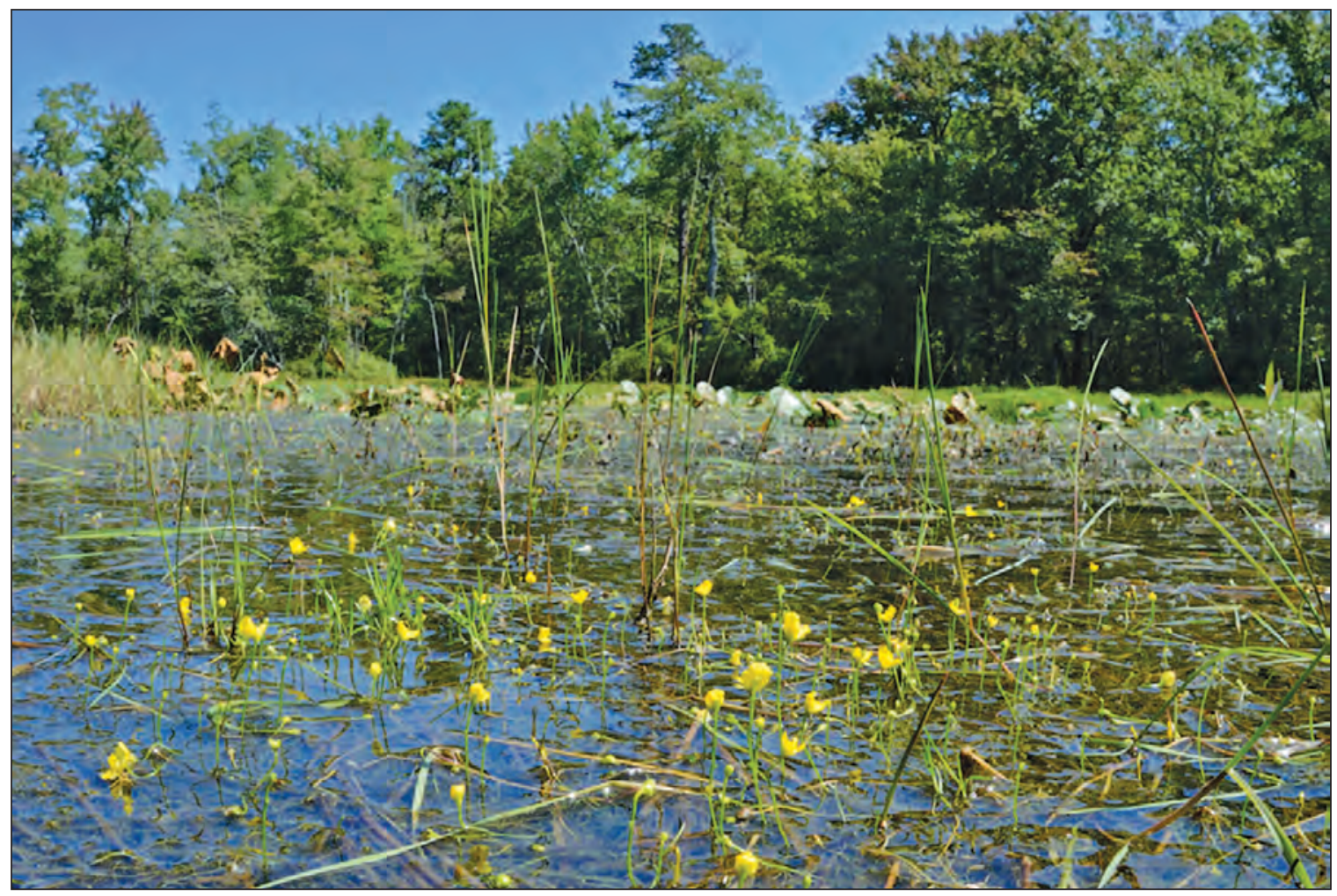

Figure H-5. Deep Run Ponds, Rockingham County, Virginia. Photograph by Gary Fleming, Virginia Department of Conservation and Recreation.

ranging from permanently ponded to highly ephemeral, based on qualitative observations of ponding conditions during repeated site visits over a decade, supplemented by air photos as early as the 1930s. They noted large hydrologic variability between ponds and, for some ponds, variability from one year to another. Although qualitative in nature, these observations support the argument by Buhlmann and others (1999) that karst-depression wetlands of the Shenandoah Valley constitute a coherent hydroecological system whose preservation depends upon the resilience offered by high degrees of spatial and temporal hydrologic variability.

\section{The Dougherty Plain}

The Dougherty Plain is one of several Coastal Plain "belts" that wrap, crescent-like, around the southern end of the Appalachians (Fenneman and Johnson, 1946; U.S. Environmental Protection Agency, 2013). In contrast to the lithologic variability of the Highland Rim and the structural and geomorphic complexity of the Shenandoah Valley, the Dougherty Plain presents a relatively simple geologic setting. The area is dominated by a single geologic unit, the upper Eocene Ocala Limestone, which is a relatively pure karstic limestone with high primary and secondary porosity that forms the Upper Floridian aquifer (Torak and others, 1993). Locally known as the Ocala aquifer (Hicks and others, 1981), the Upper Floridan aquifer is a major water-bearing unit of the Floridian aquifer system (Miller, 1986). In the Dougherty Plain, the Ocala Limestone is typically about 165 to 230 feet (roughly 50 to 70 meters) thick and is confined at its base by the middle Eocene Lisbon Formation and discontinuously at its top by a layer of residuum with a typical thickness range of approximately 45 to 110 feet (roughly 13 to 33 meters) (Hicks and others, 1981). The residual mantle is generally reddish sandy clay (Hicks and others, 1981), but is not uniform; geophysical logs obtained near Albany, Georgia, show an extensive clay-rich layer that restricts infiltration and perches shallow groundwater above the regional water table of the Upper Floridian aquifer (Torak and others, 1993).

Sinkholes (limesinks) are widespread throughout much of the Dougherty Plain, but the relation of karst-depression wetlands to the overall sinkhole population is difficult to discern from the published literature. Torak and others (1993) reported a general range of sinkhole depths in the Dougherty Plain from less than 3 to about 25 feet (less than 1 to about 8 meters) but provided little information on their drainage characteristics beyond noting that many are filled with water year round. Hicks and others (1981) identified sinkhole collapse, along with stream-channel erosion, as a mechanism for removing the residual confining unit, producing locally unconfined groundwater conditions. A reasonable inference is that deep sinkholes are more likely to penetrate the residual confining unit than shallow ones. Where depths of limesink wetlands have been reported, they have not exceeded 6.5 feet 
(about 2 meters) (Hendricks and Goodwin, 1952; Golladay and others, 1999; Opsahl, 2005). Palik and others (2000) distinguished "shallow depression" upland ecosystems from "depression" wetlands but did not specify a depth threshold separating the two; their finding that shallow depressions are drier than deep depressions is consistent with results reported by Hendricks and Goodwin (1952).

Information on groundwater/surface-water interactions in and around limesink wetlands is largely limited to the analysis of Hendricks and Goodwin (1952). All but 2 of 13 sites had at least 15 observations of reversed gradients between the pond stages and measured groundwater levels, and 9 sites had more than 30 such observations, suggesting that flow from the groundwater system to these ponds is common when watertable elevations are high. However, these wells had relatively short screened intervals (approximately 3 feet, or 0.9 meter) and apparently shallow depth (not reported but probably less than 25 feet, or about 8 meters, based on maximum estimated groundwater levels). These well characteristics suggest that their water levels may be best interpreted as indications of hydraulic head within the residuum and not necessarily as measurements of the water-table elevation. Hydrologic interactions between the limesink wetlands and the underlying Upper Floridan aquifer do not appear to have been examined.

\section{Stress and Disturbance Regimes}

The most obvious, and in many ways dominant, abiotic stress factor in karst-depression wetlands is water. Fire, disturbance, and edaphic stresses may be present and even important, but they operate within ecological constraints determined by hydrologic stress, chiefly in the form of inundation or soil saturation.

\section{Hydrologic Stress Regimes of Karst-Depression Wetlands}

Numerous investigators have characterized karst-depression wetland hydroperiods for time scales ranging from 1 year to a decade (Hendricks and Goodwin, 1952; Wolfe, 1996a, b; Golladay and others, 1997; Battle and Golladay, 2001; O'Driscoll and Parizek, 2003; Hill and Neary, 2012). One general observation that can be drawn from these studies is that annual hydroperiod is highly variable, interannually and site to site, even within short distances. O'Driscoll and Parizek (2003) noted annual hydroperiods ranging from 33 to 192 days among 17 karst-depression wetlands monitored in 1999 within a 54-acre (22-hectare) area of the Valley and Ridge in Pennsylvania. Knox (1997) reported hydroperiods of 4 to 16 months in one Shenandoah Valley sinkhole pond monitored for 9 years.

Short-term ecological responses to variation in annual hydroperiod have been observed, including measureable differences in the composition and density of aquatic macroinvertebrate communities of Dougherty Plain limesinks (Golladay and others, 1997, 1999) and in tree recruitment in a Highland Rim karst swamp (Wolfe and others, 2004). However, the high level of variability in annual hydrologic conditions of karst-depression wetlands suggests that caution is in order when trying to relate wetland ecosystems to hydrology based on a few years of hydrologic observations at a limited number of sites. For example, Knox (1997) observed apparently universal mortality among Helenium virginicum, a federally listed threatened species, during prolonged (16 months) inundation in a 2.5-acre (1-hectare) Shenandoah Valley sinkhole pond, but concluded that blocking of light by a mat of floating live and dead vegetation was a more likely cause of mortality than duration of ponding because $H$. virginicum populations were undiminished by equal inundation depths and durations in nearby sites where floating vegetation mats were absent.

The most detailed analysis found in this review of the ecological role of hydroperiod in a karst-depression wetland is a series of studies examining Sinking Pond, an 87-acre (35-hectare) compound sink on Arnold Air Force Base, Tennessee, on the eastern Highland Rim (fig. H-6). This wetland supports an assemblage of Quercus lyrata, Betula nigra, and Pleopeltis polypodioides with a preliminary ranking of G1 (Wolfe and others, 2004; NatureServe, 2015). Wolfe (1996a, b) established the pond's hydrologic framework and related tree distribution patterns to elevation and ponding duration. Wolfe (1996b) explicitly discussed the balance of abiotic and competitive stress factors and noted suppression of $Q$. lyrata recruitment in the deepest parts of the pondattributed to unspecified effects of winter ponding - despite widespread germination of seedlings produced by apparently healthy adult trees.

McCarthy and Evans (2000) found general failure of Q. lyrata recruitment in Sinking Pond beyond the sapling stage, except in areas of shallow (less than 1.5 feet or about 0.5 meter) maximum ponding depth. They also examined age distribution and spatial patterns of adult $Q$. lyrata and concluded that an increase in hydroperiod had occurred in Sinking Pond sometime after 1950, possibly related to land-use change or geologic factors (McCarthy and Evans, 2000). Wolfe and others (2004) confirmed that an increase in hydroperiod had indeed caused recruitment failure in Sinking Pond, based on seedling plots, spatial distributions of $Q$. lyrata life-history stages, and tree-ring analysis. Having eliminated possible anthropogenic causes, Wolfe and others (2004) attributed increased hydroperiod and recruitment failure in Sinking Pond to a step increase in regional average precipitation known to have occurred around 1970 (Karl and Knight, 1998; McCabe and Wolock, 2002), based on ages and elevations of Q. lyrata and approximately 148 years of modeled daily pond stage. A tripling of the likelihood of annual inundation exceeding 200 days (17 percent before 1970, 54 percent after) represents the hydrologic threshold separating successful and repressed recruitment of Q. lyrata in Sinking Pond (Wolfe and others, 2004, p. 33-36). 

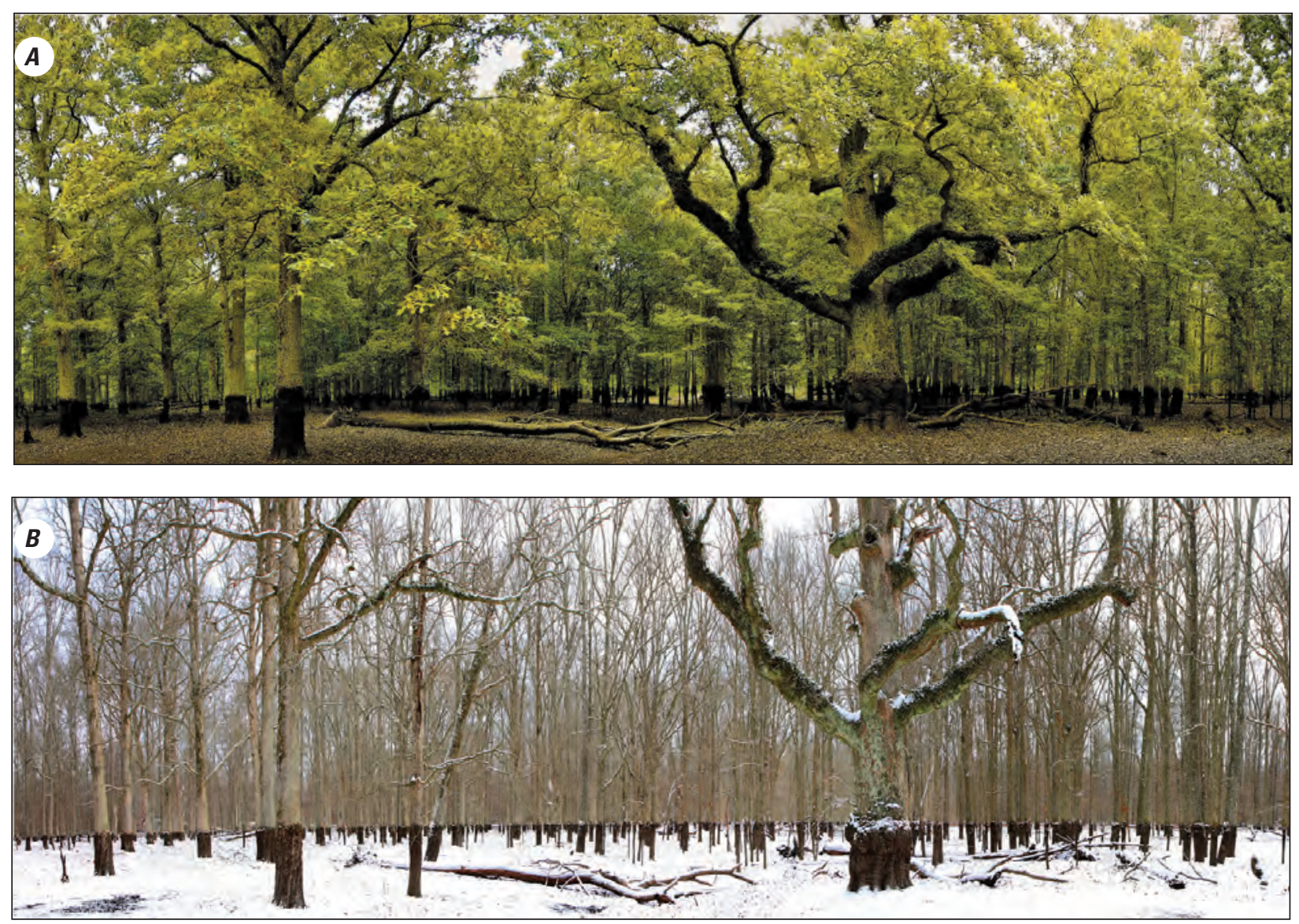

Figure H-6. Two views of Sinking Pond, Arnold Air Force Base, Coffee County, Tennessee: $A$, fully drained with leaves on in the summer, and $B$, fully drained with snow in the winter. Visible in both photos but most striking in winter is the moss line at the base of the trees, marking the typical high-water elevation. Photographs by Michael Hodge, retired, Arnold Engineering Development Center.

\section{Fire, Disturbance, Water Quality, and Edaphic Stress}

The roles of fire and mechanical disturbance in the abiotic stress regimes of karst-depression wetlands have received limited scientific attention, with most of this research having been conducted in the Dougherty Plain. Limesinks of the Dougherty Plain are generally embedded within a longleaf pine ecosystem (fig. H-7) in which savanna-like physiognomy and herbaceous species richness are maintained by frequent (1-10-year interval), low-intensity fires (Drew and others, 1998). Drew and others (1998) presented a conceptual model of interactions between fire and hydroperiod as a determinant of ecosystem composition, structure, and trajectory. Martin (2006) examined the effects of mowing and fire in 10 limesink wetlands, showing that these treatments produced a shift from woody to herbaceous vegetation facilitated by soil-based seed banks that included herbaceous species; such shifts might be stable if the fire and disturbance regimes were maintained. Conversely, shifts in the fuel structure, possibly driven by climate change or invasive plants such as Lygodium japonicum, might alter either the maintenance and composition of seed banks or the general behavior of fire in these wetlands, potentially producing new plant assemblages rather than restoring native herbaceous communities (Martin, 2006).

Historically, fire was important in maintaining the barrens matrix in which Highland Rim karst-depression wetlands are locally concentrated (Wolfe, 1996b), but little if any detailed examination of fire's role within these wetlands has been attempted. One Highland Rim karst pan, Goose Pond in Coffee County, Tennessee, supports a natural marsh community dominated by Panicum hemitomon (DeSelm, 1973) with little apparent need of fire or mowing to keep woody vegetation confined to the pond margins, though one prescribed burn reportedly was conducted in the 1990s (Geoff Call, U.S. Fish and Wildlife Service, oral commun., 2015).

Water quality has received limited attention as an abiotic stressor in karst-depression wetlands, but it appears to play a discernible ecological role in some contexts. Low pH (less than 6) and low acid neutralizing capacity (less than 20 acid-base microequivalents per liter) of some Shenandoah Valley sinkhole ponds create an apparently 


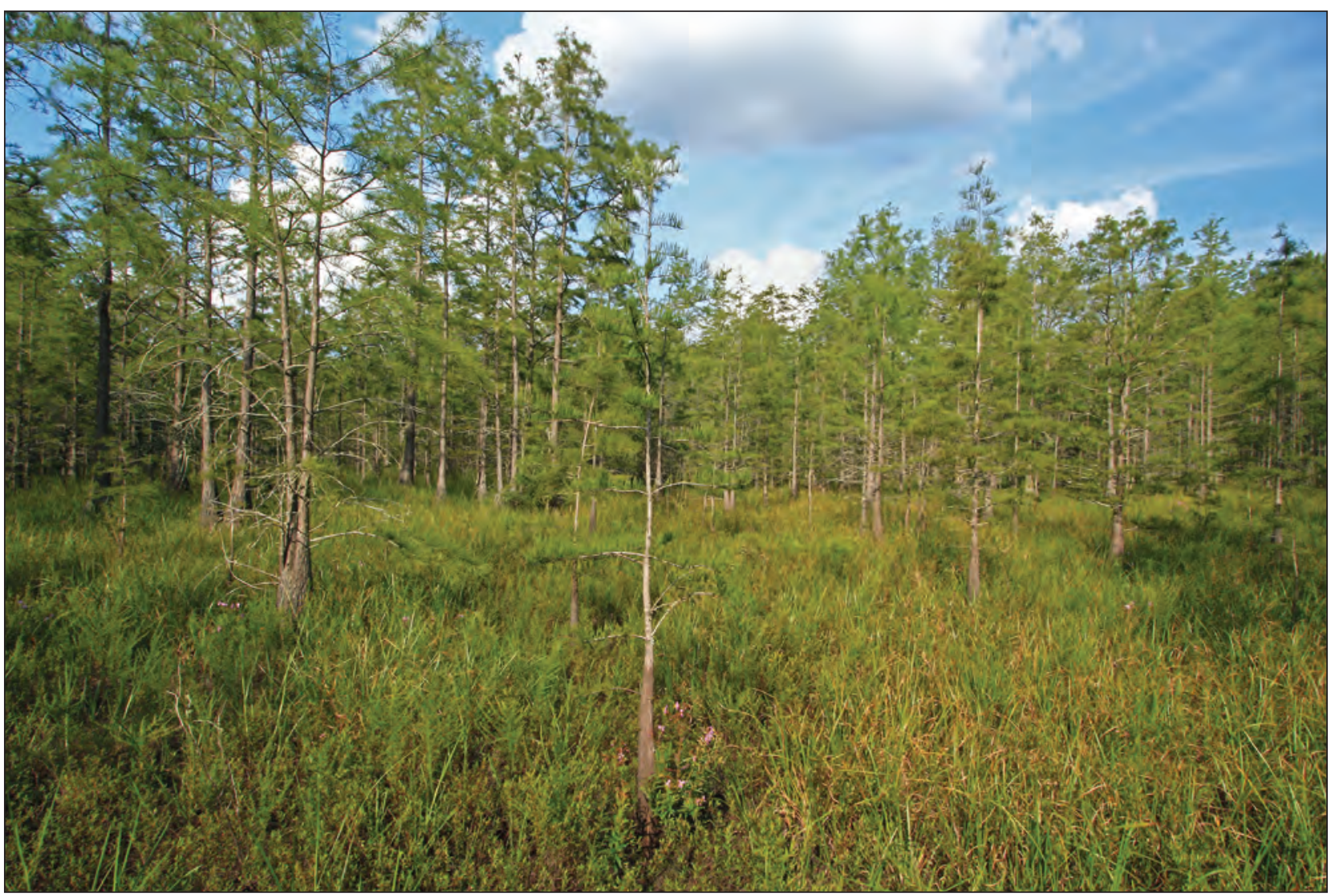

Figure H-7. Neyami Pond, Lee County, Georgia. Photograph by Alan M. Cressler, U.S. Geological Survey.

stressful but tolerable environment for the eggs and larvae of Ambystoma tigrinum (tiger salamander), which is state-listed as endangered in Virginia (Downey and others, 1999). Among Dougherty Plain limesinks, cypress-gum swamps, cypress savannahs, and grass-sedge marshes each have distinctive water-quality profiles, with swamps having greater concentrations of nutrients and dissolved organic carbon than the other community types (Battle and Golladay, 2001; Liner and others, 2008). Water-quality patterns and vegetation structure correlate to at least some measures of animal diversity. Macroinvertebrate diversity was highest in marshes and lowest in swamps (Battle and Golladay, 2001). Swamps had the lowest larval species richness for frogs and toads but the highest for salamanders (Liner and others, 2008).

Edaphic stress not related to soil saturation is another component of the karst-depression wetland stress regimes that has received little attention. The fragipans that characterize soils in areas of the Eastern Highland Rim are found in karst depressions and in the surrounding uplands (Love and others, 1956). Wolfe (1996b) noted that rooting depths of Quercus lyrata and other trees in Highland Rim karst swamps were limited to about 3 feet (approximately 1 meter) or less by this fragipan, independent of soil saturation, producing a characteristic mode of failure through tipping over, root mat intact, rather than through broken trunks.

\section{Community Types and Vegetation Dynamics}

At the broadest level, karst-depression wetland community types can be divided into major classes based on vegetation physiognomy. Swamps are wetlands with a closed forest canopy and moderate-to-sparse shrub cover, savannas have a relatively open canopy and herbaceous understory, and marshes are predominantly herbaceous, often without a distinct overstory (Kirkman and others, 2000). Individual karst depressions may contain one or more of these broad vegetation types, with or without inclusions of open-water habitat.

Swamps in karst-depression wetlands are dominated by inundation-tolerant woody taxa. Many karst-depression wetlands on the Highland Rim are swamps; however, marsh and open-water habitats are also present (Ellis and Chester, 1989; McKinney, 1989; Wolfe, 1996b). Typically, forest species composition differs substantially between depression wetlands and the surrounding uplands - which may be mixed mesophytic forest or oak-hickory forest - based on differential tolerance of prolonged soil saturation, which causes anoxic conditions (Roberts and others, 2004). Upland species intolerant of anoxic soil are effectively excluded from karst-depression wetland communities, providing competitive 
advantage to obligate and facultative wetland species. On the Highland Rim, common tree-canopy constituents in karst-depression wetlands include Acer rubrum, several Quercus species (Q. bicolor, Q. lyrata, Q. phellos, and Q. palustris), Fraxinus pennsylvanica, Ilex decidua, Liquidambar styraciflua, Platanus occidentalis, Nyssa sylvatica, and Ulmus americana (Hannan and Lassetter, 1982; Ellis and Chester, 1989; Patterson, 1989; Cranfill, 1991; Roberts and others, 2004). Common components of the shrub layer include Alnus serrulata, Sparganium americanum, Photinia melanocarpa, Cephalanthus occidentalis, Decodon verticillatus, Hibiscus moscheutos, Ilex verticillata, Itea virginica, Parthenocissus quinquefolia, Toxicodendron radicans, Rosa palustris, Sambucus nigra ssp. canadensis, and Vaccinium species (Delcourt, 1979; Ellis and Chester, 1989; Cranfill, 1991; Roberts and others, 2004). Swamp habitat in depression wetlands on the Dougherty Plain is commonly dominated by Taxodium ascendens and Nyssa biflora in the tree canopy, and thus is referred to as cypress-gum swamp, with Liquidambar styraciflua and Quercus and Salix species at swamp margins (Hendricks and Goodwin, 1952; Drew and others, 1998; Kirkman and others, 2000). Shrub components in these cypress-gum swamps can include Cephalanthus occidentalis, Ilex myrtifolia, Styrax americanus, Leucothoe racemosa, Clethra alnifolia, and Lyonia lucida (Hendricks and Goodwin, 1952; Kirkman and others, 2000).

Grass-sedge marshes are primarily composed of submerged and emergent aquatic and semiaquatic plants. Such marshes are an important community type in limesink wetlands of the Dougherty Plain, with community constituents from the genera Rhexia, Rhynchospora, Lespedeza, Juncus, Panicum, Typha, Scirpus, Xyris, and Andropogon (Hendricks and Goodwin, 1952; Drew and others, 1998; Kirkman and others, 2000). In these marshes, important aquatic constituents include species of the genera Ludwigia, Myriophyllum, Nymphaea, Limnobium, Potamogeton, and Lemna (Hendricks and Goodwin, 1952; Kirkman and others, 2000). A few examples of marsh habitat in karst depressions have also been described on the Highland Rim. Goose Pond (McKinney, 1989), Anderson Pond, and Mingo Pond (Delcourt, 1979; Ellis and Chester, 1989), all on the Eastern Highland Rim of Tennessee, support zones of aquatic macrophytic communities and grass-sedge communities along gradients of inundation depth surrounded by swamp forest. At these sites, common marsh taxa include Dulichium arundinaceum, Pontederia cordata, and species of the genera Sagittaria, Eleocharis, Scirpus, Rhynchospora, Panicum, Juncus, and Polygonum, and aquatic macrophytes inhabiting semipermanent pools include Myriophyllum tenellum, Ceratophyllum echinatum, C. demersum, and species of the genera Lemna, Polygonum and Spirodela (Delcourt, 1979; Ellis and Chester, 1989; McKinney, 1989).

In Shenandoah Valley sinkhole ponds, physiognomy can vary from savanna-woodland types to entirely herbaceous with sparse-to-absent shrub cover (fig. H-8). Woodland areas commonly include scattered individuals and groves of Quercus palustris (Fleming and Van Alstine, 1999). Important herbaceous species include Eleocharis acicularis, Agrostis perennans, Hypericum boreale, Bidens frondosa, Viola lanceolata, and species of the genera Panicum and Rhexia (Buhlmann and others, 1999; Fleming and Van Alstine, 1999; Fleming and Patterson, 2012). A community subtype found in these sinkhole ponds and in some sinkhole ponds in Coffee County, Tennessee, tends to develop in comparatively drier, seasonally flooded areas and is strongly dominated by Carex barrattii, which is disjunct to the Coastal Plain (Sorrie and Weakley, 2001; Fleming and others, 2012). An additional subtype strongly dominated by Orontium aquaticum is limited to a single, permanently flooded pond with relatively stable water levels because of continual groundwater inputs (Buhlmann and others, 1999).

The dynamics of plant community composition in karstdepression wetlands are regulated by a number of interacting factors, probably the most important of which is hydroperiod (Roberts and others, 2004). Within semipermanently inundated karst-depression wetlands of the Highland Rim, vegetation is typically zoned. The central, most permanently inundated zone is generally dominated by aquatic herbaceous species because of the exclusion of woody species. The surrounding zone of seasonally variable inundation generally supports tree and understory communities similar to those of seasonally inundated depressions but with the addition of two notable species: Quercus lyrata and Cephalanthus occidentalis. Common species within the most permanently inundated zone include Panicum hemitomon, Juncus repens, Dulichium arundinaceum, Rhynchospora corniculata, Hibiscus moscheutos, Saccharum baldwinii, Scirpus cyperinus, and species of the genera Potamogeton, Lemna, and Polygonum, with a few observed instances of semipermanently inundated depressions dominated by relatively homogenous stands of Nyssa aquatica (Roberts and others, 2004). Hannan and Lassetter (1982) reported stratification of the herbaceous community at Brodhead Swamp Forest on the Eastern Highland Rim in Kentucky, with Proserpinaca palustris being the only herbaceous species in the deepest zones of longest hydroperiod and with a more diverse assemblage of Carex lupuliformis, C. normalis, C. typhina, Fraxinus pennsylvanica, and Acer rubrum dominating the herbaceous-seedling strata in zones of shallower water and shorter hydroperiod. Species diversity in deep water areas was generally low except where increased microrelief was provided by stumps, fallen logs, and the bases of trees.

In a study of limesinks on the Dougherty Plain, Kirkman and others (2000) found cypress-gum swamps to have generally higher organic accumulations of soil and longer hydroperiods than cypress savannas or grass-sedge marshes and to develop at locally lower elevations than the other community types. Inundation depth and timing also 


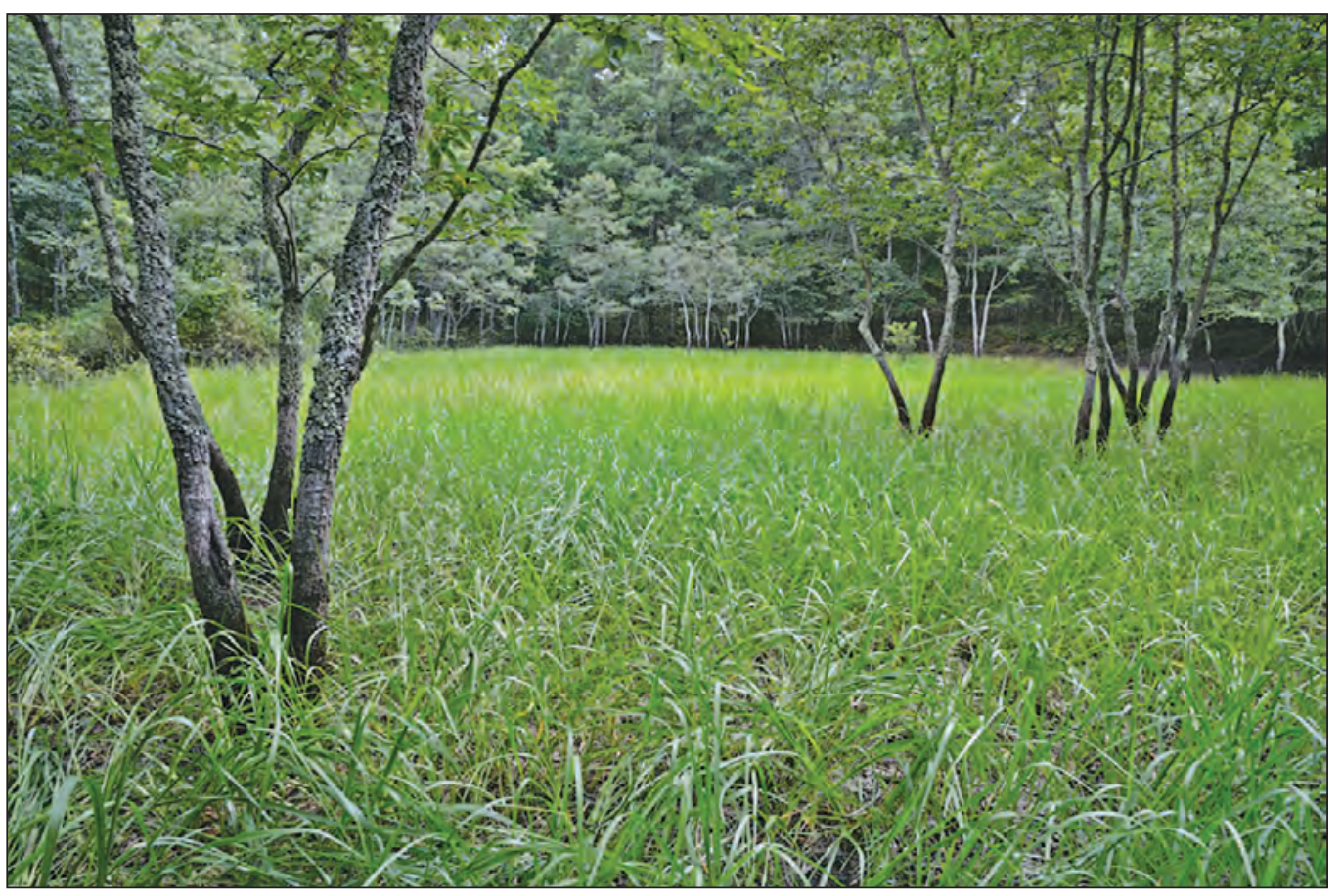

Figure H-8. Davidson Run Pond, Rockbridge County, Virginia. Photograph by Gary Fleming, Virginia Department of Conservation and Recreation.

appear to be of central importance in regulating vegetation zones in Shenandoah Valley sinkhole ponds, where episodic establishment of Quercus palustris is believed to be enabled by prolonged droughts, and several community types are restricted to zones of semipermanent inundation (Fleming and Van Alstine, 1999).

In addition to hydroperiod and inundation depth, other important controls on community composition in karst-depression wetlands include disturbance regimes, spatial patterns of shading, and ecological processes such as herbivory, disease, and competition (Roberts and others, 2004). Small-scale, frequent disturbance events can include the mortality of individual trees and localized damage from storms. Disturbance from fire can also be an important factor during dry periods and can affect the surrounding upland forest community even if wet conditions exclude fire from depressions themselves. For limesink wetlands of the Dougherty Plain, Kirkman and others (2000) proposed a model whereby interactions of fire frequency and inundation depth and duration regulate community type, ranging from grasssedge marsh (maintained by inundation-based mortality of Pinus species and fire-based mortality of cypress and hardwoods) to cypress-gum swamp (maintained by inundationbased mortality of hardwoods and pines). In karst-depression wetlands of this region, species-rich herbaceous communities may be largely sustained by fire regimes, such that anthropogenic fire suppression may result in hardwood encroachment and establishment (Martin, 2006; Martin and Kirkman, 2009).

\section{Contributions to Regional Biodiversity}

Like other small, geographically isolated wetlands in the southeastern United States, karst-depression wetlands contribute to regional floral and faunal biodiversity at levels disproportionate to their collective geographic size (Kirkman and others, 2012). In addition to supporting regionally rare plant taxa, these wetlands also provide important habitat for animals including birds, amphibians, and invertebrates.

\section{Endemic and Biogeographically Disjunct Plant Taxa}

While many of the plant taxa composing vegetation communities in karst-depression wetlands are geographically widespread, karst-depression wetlands in several regions are known to support certain plant taxa that are rare locally, regionally, and in some cases globally, and thus make important contributions to biodiversity (DeSelm, 1990; Sutter and Kral, 1994). For example, Helenium virginicum (fig. H-9) appears to be narrowly endemic to Shenandoah Valley sinkhole ponds and is federally listed as threatened (Knox, 1997; Fleming and Van Alstine, 1999). Hypericum lissophloeus is apparently restricted only to karst-depression wetlands in two counties of the Florida panhandle on the Dougherty Plain (Sorrie, 2012). Ranked G1, Isoetes virginica is present in karst-depression wetlands of the Shenandoah 


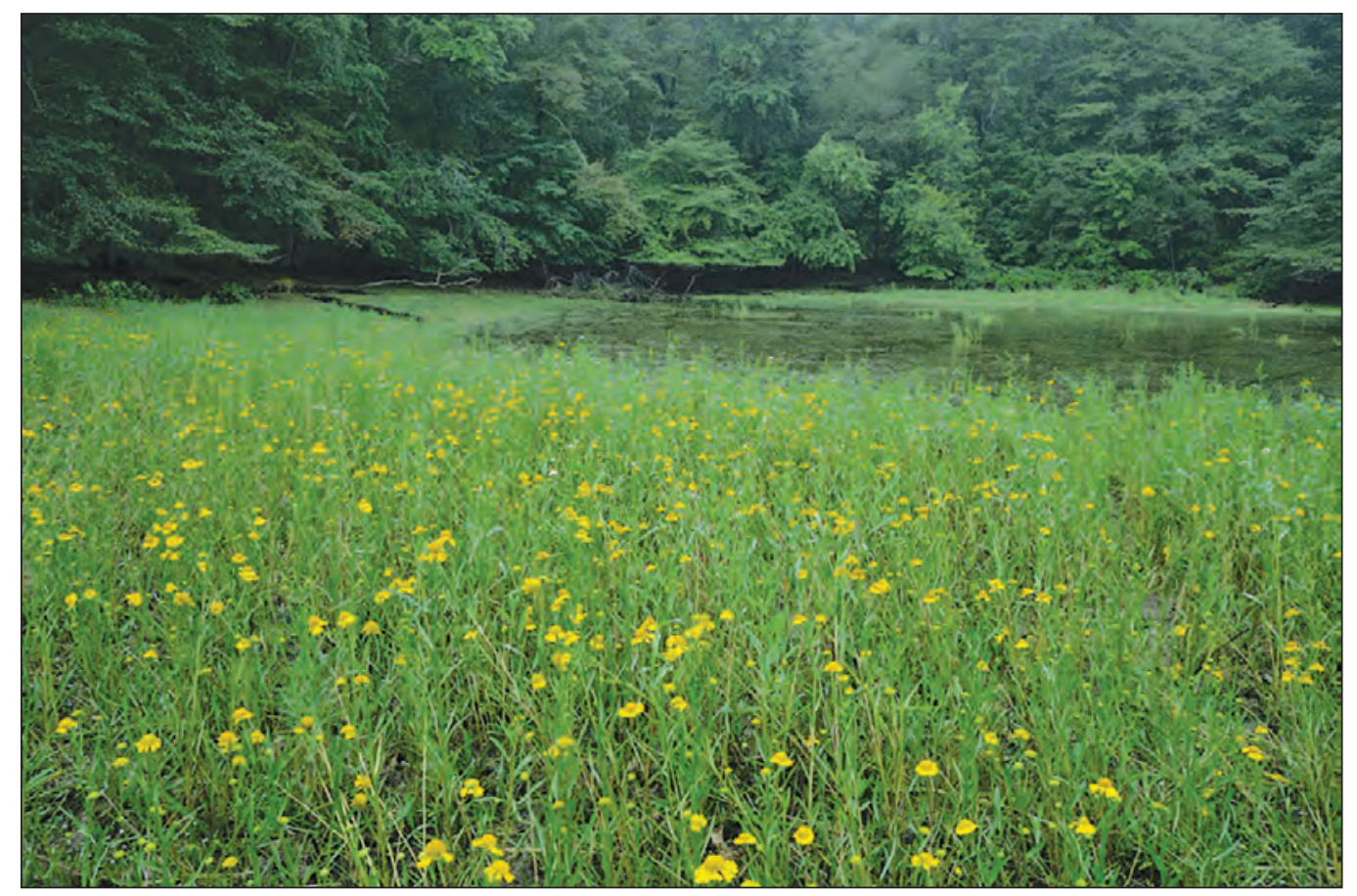

Figure H-9. Helenium virginicum at Twin Ponds, Maple Flats Pond Complex, Augusta County, Virginia. Photograph by Gary Fleming, Virginia Department of Conservation and Recreation.

Valley and also in related wetland contexts, such as woodland ponds and streams (Fleming and Van Alstine, 1999; Franklin and Finnegan, 2006). At one well-studied site containing a cluster of karst-depression wetlands, Arnold Air Force Base on the Highland Rim of Tennessee, dozens of rare and endangered plants have been documented, primarily within or near karst-depression wetlands (Wolfe, 1996b). In a number of cases, botanical surveys of karst-depression wetlands have produced new additions to state flora (Homoya and Hedge, 1985; Ellis and Chester, 1989).

A primary reason for the concentration of locally rare plant taxa in and around karst-depression wetlands is support for taxa that are biogeographically disjunct from home ranges in other physiographic provinces. For karst-depression wetlands of the Interior Low Plateaus, the primary pattern of disjunction appears to be to the Coastal Plain (DeSelm, 1990), a phenomenon that has been attributed to these wetlands functioning as refugia for relict species from the Tertiary Period when the Interior Low Plateaus included vast swamps with a subtropical climate (Hannan and Lassetter, 1982; Homoya and Hedge, 1985). Examples of Coastal Plain taxa present in karst-depression wetlands of the Interior Low Plateaus include Ludwigia sphaerocarpa in Mingo Swamp in Tennessee (Ellis and Chester, 1989); Panicum hemitomon, Lachnanthes caroliana, Lobelia canbyi, Xyris laxifolia var. iridifolia,

Sagittaria graminea var. graminea, and Woodwardia virginica in Goose Pond in Tennessee (McKinney, 1989; Grant and others, 2003); Platanthera flava var. flava, Triadenum walteri, and Ranunculus pusillus at Brodhead Swamp Forest on the Eastern Highland Rim in Kentucky (Hannan and Lassetter, 1982); and Carex gigantea, C. decomposita, Triadenum walteri, Woodwardia areolata, Rhynchospora corniculata, Itea virginica, and Ranunculus pusillus in karst-depression wetlands of southern Indiana (Homoya and Hedge, 1985). Coastal Plain affinities have also been noted for Shenandoah Valley sinkhole ponds, which support populations of Panicum hemitomon and Lachnanthes caroliana, in addition to Coastal Plain taxa such as Utricularia striata, Carex barrattii, Eleocharis melanocarpa, and E. robbinsii, all of which are ranked S1 or S2 in Virginia (Buhlmann and others, 1999; Fleming and Van Alstine, 1999; Townsend, 2015).

Certain other plant taxa in karst-depression wetlands of the Interior Low Plateaus and the Valley and Ridge are disjunct to ranges farther north or west. Carex aquatilis, for example, has a widespread distribution in Canada and the Rocky Mountains of the United States, but is ranked S1 in Virginia where it is known only from the Big Levels-Maple Flats region (Fleming and Van Alstine, 1999). Cedar Hill Swamp on the Western Highland Rim of Tennessee supports several State-rare emergent and floating aquatic species, including Ranunculus flabellaris (disjunct to New England and the northern Midwest States) and Carex rostrata (disjunct from the most northern regions of New England and the northern Midwest) (Chester and Ellis, 1989; Ellis and Chester, 1989). 
In addition to the presence of regionally rare individual species, karst-depression wetlands also support rare assemblages and communities. The deeper zones of Sinking Pond on the Highland Rim of Tennessee support an assemblage of overcup oak, river birch, and resurrection fern (Quercus lyrata, Betula nigra, and Pleopeltis polypodioides, respectively) that is ranked G1 (Patterson, 1989; Wolfe and others, 2004) and has thus far not been documented anywhere else in the world (NatureServe, 2015). Similarly, Shenandoah Valley sinkhole ponds support an herbaceous assemblage dominated by Carex barrattii that is known from only two karst ponds in Augusta County, Virginia (Fleming and Patterson, 2012).

\section{Animal Habitat}

A number of birds and mammals rely on karst-depression wetlands to provide some of their habitat needs and in turn shape these ecosystems through trophic interactions. Important mammalian predators in karst-depression wetlands include Neovison vison (American mink), Procyon lotor (common raccoon), and Lontra canadensis (North American river otter) (Roberts and others, 2004). Karst-depression wetlands provide important breeding grounds and foraging opportunities for a number of bird species. On the Highland Rim of Tennessee, Aix sponsa (wood duck) uses karst-depression wetlands and other forested wetlands year round (Roberts and others, 2004). Karst-depression wetlands on the Western Highland Rim support populations of Ardea herodias (great blue heron) and appear to have served as a refugia for this species during the 1960s when a number of large colonies were lost in Tennessee due to habitat destruction (Fleming and others, 1984;

Pullin, 1990).

One of the most biologically important features of karst-depression wetlands is their role as habitat for amphibians and reptiles. For example, Shenandoah Valley sinkhole ponds provide habitat to locally rare Ambystoma tigrinum (eastern tiger salamander) and Clemmys guttata (spotted turtles) (Buhlmann and others, 1999). Seasonally inundated, isolated wetlands of the southeastern Coastal Plain, such as the limesink wetlands on the Dougherty Plain, also provide important amphibian habitat (Smith and others, 2006), helping support as many as 36 amphibian species (Moler and Franz, 1987). A notable example is Ambystoma cingulatum (frosted flatwoods salamander), which is endemic to a small part of the Coastal Plain and is thus ranked G2 and is federally listed as threatened (Sutter and Kral, 1994). Certain areas of the Highland Rim, such as the upper Duck River watershed in Coffee County, Tennessee, have been documented as sites of exceptional biodiversity for amphibians and reptiles, due in part to habitat heterogeneity afforded by karst-depression wetland ecosystems (Niemiller, 2005). Miller and others (2005) documented several species of State or Federal concern associated with wetland habitat in karst-depression wetlands on the Highland Rim, including Ambystoma talpoideum (mole salamander), Hemidactylium scutatum (four-toed salamander), and Hyla gratiosa (barking treefrog). The G3-ranked Lithobates capito (gopher frog) occupies some karst-depression wetlands of the Highland Rim in Tennessee, where it is ranked S1, and in the Dougherty Plain, where it is ranked S2 in Alabama and S3 in Georgia (Sutter and Kral, 1994; Miller and others, 2005; NatureServe, 2015).

In some cases, certain reptiles and amphibians tend to remain within the depression-wetland boundary-including Nerodia sipedon (northern water snake), N. erythrogaster (plain-bellied water snake), Lithobates catesbeianus (American bullfrog), L. clamitans (green frog), and Chelydra serpentina (common snapping turtle) - whereas others use both wetland and adjacent upland habitats (Miller, 1995). Those amphibians and semiaquatic reptiles that require a combination of wetland and terrestrial habitat for feeding, nesting, or hibernating may use areas that are hundreds of meters from the water's edge (Buhlmann and others, 1999; Semlitsch and Jensen, 2001; Semlitsch and Bodie, 2003).

Seasonal wetlands such as karst-depression wetlands are especially important to amphibians because their reproduction necessitates access to water and because many species display a high degree of philopatry to particular breeding sites; thus, the decline of amphibian species across the southeastern United States can be attributed in part to wetland habitat loss (Roberts and others, 2004). Some evidence suggests that differences in hydroperiod and vegetation physiognomy between different karst-depression wetlands drive differences in amphibian community structure. Liner and others (2008), for example, observed relatively higher species richness of salamanders in cypress-gum swamps with relatively long hydroperiods and high canopy cover, and relatively low species richness of amphibians with long larval periods, such as aquatic salamanders, in cypress savannas with shorter hydroperiods and less canopy cover. Thus, conservation of the full suite of amphibian biodiversity supported by karstdepression wetlands likely requires conservation of diverse habitat types afforded by these wetlands.

Some evidence exists for high invertebrate diversity in habitats provided by karst-depression wetlands. For example, Shenandoah Valley sinkhole ponds support an exceptional diversity of odonates, making this ecosystem type a locally important habitat resource for this insect group (Buhlmann and others, 1999). In a study of a number of diverse habitats at The Barrens at Arnold Air Force Base, two karst wetland sites - Sinking Pond and Goose Pond - had the highest species richness of ambrosia and bark beetles (Coleoptera: Curculionidae) and of darkling beetles (Tenebrionidae) (Grant and others, 2003; Wiggins and others, 2007). In the same study, Sinking Pond yielded a specimen of Wormaldia shawnee (a fingernet caddisfly), the first record of an adult in Tennessee. A new State record was also reported for Pycnopsyche rossi (a northern casemaker caddisfly) found in a grove of Nyssa aquatica (Wiggins and Etnier, 2001). Overall insect diversity 
at Sinking Pond as measured by the Shannon Index was high, with moderate evenness (Vlach, 1999; Vlach and others, 2010). Four species collected at Sinking Pond-Cicindela unipunctata (one-spotted tiger beetle), Lethe anthedon (northern pearly-eye), Glaucopsyche lygdamus (silvery blue), and Speyeria cybele (great spangled fritillary) - are state-listed as endangered, rare, or threatened in neighboring States (Alabama or North Carolina) (Vlach and others, 2010). In a study of macroinvertebrates in karst-depression wetlands of the Dougherty Plain, Battle and Golladay (2001) found higher taxa richness in marsh habitat than in cypress savannas or cypress-gum swamps and suggested that a higher variety of food sources and habitat structures in marshes may have explained this, along with stress associated with low dissolved-oxygen conditions in swamp habitat.

One of the most prominent sets of environmental factors affecting animal habitat is the interaction of hydroperiod, timing of inundation, and inundation depth. Amphibian density and diversity are largely regulated by hydroperiod. If hydroperiod is too short, habitat becomes unavailable for part of the time required for egg development and larval maturation. Conversely, if hydroperiod is long enough to allow the establishment of predatory fish, then predation on eggs, juveniles, and adults may dramatically reduce amphibian populations (Sutter and Kral, 1994; Roberts and others, 2004). Based on a study of invertebrates in limesink wetlands on the Dougherty Plain, Golladay and others (1997) suggested that abnormally long inundation may have suppressed populations of amphipods and isopods by depriving them of summer refugia and may have interrupted life-cycle completion for cladocerans and copepods.

For mammals and birds, forest composition and structure are important habitat characteristics. Species composition of the overstory commonly affects food availability. For example, oaks provide a valuable food source in the form of acorns for a variety of mammals and birds. Habitat structural complexity, determined by the vertical distribution of foliage layers within the canopy, is an especially important habitat characteristic for birds. The age and size of the largest trees influence availability of tree cavities for nesting. In addition, tree density directly relates to rates of fruit production and to shrub cover density of the understory (Roberts and others, 2004).

\section{Conservation Considerations}

Conservation of karst-depression wetlands is an important component of regional biodiversity conservation because these ecosystems provide key habitat to plant and animal species, including rich assemblages of aquatic vertebrates and invertebrates as well as plant species with disjunct distributions. Conservation of karst-depression wetlands is also important from an ecosystem services perspective because these wetlands provide a number of geologic and hydrologic functions, including groundwater recharge, flood peak attenuation, sediment retention, water-quality improvement, and the sequestration of carbon, metals, and environmental contaminants (Roberts and others, 2004; Hill and others, 2006). Conservation of these wetlands involves addressing a range of interrelated threats, consideration of landscape and hydrologic contexts surrounding wetlands, and scientific attention to key knowledge gaps.

\section{Threats to Ecosystem Integrity}

In many locations, karst-depression wetlands and their associated upland areas have a history of anthropogenic damage. Commonly, karst-depression wetlands were ditched, drained, and (or) filled to enable conversion to agricultural production while surrounding upland forests were logged and cleared for agriculture (Hannan and Lassetter, 1982; Baskin and others, 1997; Buhlmann and others, 1999; Kirkman and others, 1999; Roberts and others, 2004). The three karstdepression wetlands described by Ellis and Chester (1989) had all been altered by human activities, including logging, trash dumping, agricultural use, and road and railroad construction. The vast majority of karst-depression wetlands examined by Homoya and Hedge (1985) in southern Indiana also were highly disturbed. Residential, industrial, and commercial development is also a primary threat to karst-depression wetlands (Hannan and Lassetter, 1982; Sutter and Kral, 1994; Buhlmann and others, 1999; Roberts and others, 2004).

In some cases, the basin geomorphology of karst depressions has been intentionally altered (such as by infilling), but in other cases the alteration has been unintentional and indirect. Erosion and sediment transport accelerated by construction and agriculture can increase the rate of sedimentation in karst-depression wetlands, which often serve as sediment sinks for the surrounding landscape due to their low topographic position. Logging activities can alter the evapotranspiration patterns of karst-depression wetlands and their adjacent uplands and also can make nearby upland soils more prone to erosion, leading to increased sedimentation of karst-depression basins (Wolfe, 1996b; Roberts and others, 2004). If this sedimentation increase is sufficiently high it can, in turn, affect basin geomorphology and consequently hydrology (Wolfe, 1996b; Roberts and others, 2004).

Watershed-scale land-use changes can have important indirect effects on karst-depression wetlands through localized hydrologic alteration. Because these wetlands commonly receive surface-water inputs as runoff from surrounding upland areas, land-use changes that alter the imperviousness of the watershed or divert the flow of runoff can have profound effects on the hydrologic regime of karst-depression wetlands (Roberts and others, 2004). In some cases, these changes can be modeled and predicted. Using a soil-plant-atmospherewater model to simulate biological responses to altered 
hydrology under different land-management scenarios, Hill (2007) predicted an overall decrease in species diversity in the Algood wetland on the Highland Rim in Tennessee under scenarios of increased conversion of watershed area to impervious surfaces.

In addition, threats from anthropogenic hydrologic alteration can be associated with groundwater changes. Because some types of karst-depression wetlands, such as compound sinks, are closely connected to groundwater, localized groundwater extraction that results in changes to the local water table has the potential to seriously alter wetland hydrologic regimes (Wolfe, 1996b). Because patterns of inundation and saturation largely determine the soil biogeochemistry of karst-depression wetlands based on seasonal patterns of oxic and anoxic conditions, anthropogenic hydrologic alteration (whether from land-use change or groundwater extraction) can produce a cascade of secondary consequences in terms of nutrient cycling, the sequestration of metals and carbon, and plant and animal community dynamics (Roberts and others, 2004).

Certain vegetation community types - such as cypress savannas and grass-sedge marshes within karst-depression wetlands of the Dougherty Plain - appear to be heavily dependent on disturbance from fire (Kirkman and others, 2000). For these communities, anthropogenic fire suppression commonly results in hardwood establishment, and thus the diminution of herbaceous habitat and the degradation of herbaceous biodiversity (Kirkman and others, 2012). Once a threshold of woody dominance is surpassed, the accumulation of fire-resistant litter can allow clusters of hardwoods to persist even after the reintroduction of historical fire regimes (Martin and Kirkman, 2009).

A range of other emerging threats may affect karstdepression wetland ecosystems. Although some invasive exotic plant species of the surrounding uplands are excluded from karst-depression wetlands due to soil saturation, certain stress-tolerant invasives have the potential to destabilize communities in karst-depression wetlands, including Ligustrum vulgare, Lonicera japonica, and Microstegium vimineum (Roberts and others, 2004). Exotic insect species have also been noted in karst-depression wetlands (Vlach and others, 2010). Contamination may also threaten some biota. For example, Fleming and others (1984) reported unusually high levels of polychlorinated biphenyls in a great blue heron egg from a colony at Sinking Pond on the Eastern Highland Rim. The effects on water chemistry from acid precipitation have also been mentioned as a possible threat to amphibians and invertebrates breeding in Shenandoah Valley sinkhole ponds (Buhlmann and others, 1999; Downey and others, 1999). Additionally, land-use changes of the upland areas surrounding karst-depression wetlands can also affect wildlife through habitat fragmentation, a process known to affect species diversity and population genetic diversity with disproportionate effects on species with highly specialized habitat requirements (Roberts and others, 2004).

\section{Conservation Strategies}

A number of karst-depression wetlands are being monitored by conservation agencies and are on publicly protected land. Protected or publicly owned sites in the Interior Low Plateaus include Arnold Air Force Base in the Eastern Highland Rim of Tennessee (the location of two National Natural Landmarks: Goose Pond and Sinking Pond), Chaney Lake in Warren County, Kentucky, and Cedar Hill Swamp in Robertson County, Tennessee (Wolfe, 1996b; Baskin and others, 1997; Haugh, 2006; Wiggins and others, 2007). In the Shenandoah Valley, the Loves Run Pond Complex and the Maple Flats Pond Complex are managed by the U.S. Forest Service (Buhlmann and others, 1999). On the Dougherty Plain, a dense concentration of karst wetlands and associated longleaf pine and wiregrass are protected within Ichauway, an approximately 29,200-acre (11,800-hectare) private reserve in Baker County, Georgia (Drew and others, 1998; Kirkman and others, 2000; Smith and others, 2006). These important sites notwithstanding, researchers of karst-depression wetlands have argued that current national wetland policy is inadequate to protect these ecosystems because of their small geographic size and relative isolation from surface-water networks (Sutter and Kral, 1994; Kirkman and others, 1999; Kirkman and others, 2012).

Effective conservation of karst-depression wetlands and the biological communities they support requires consideration of landscape-level processes and interactions with the surrounding terrestrial environment. Inadequate protection of terrestrial habitat for wetland-breeding amphibians is predicted to reduce amphibian biodiversity and to result in localized extinction for vulnerable species (Harper and others, 2008). As is the case with other geographically isolated wetlands, conservation of amphibian species that use karst-depression wetlands to complete their life cycle requires conservation of the entire species habitat, which includes terrestrial zones necessary for feeding, nesting, and overwintering. Herpetologists have argued that conservation of upland terrestrial habitat should be driven by an understanding of individual species' biological requirements and the maximization of connectivity between wetlands, rather than simply based on buffer strips of an arbitrary distance (Semlitsch, 1998; Buhlmann and others, 1999; Semlitsch and Jensen, 2001; Semlitsch and Bodie, 2003).

Additionally, biodiversity conservation in karstdepression wetlands requires preservation of the diversity of habitat types provided by these wetlands because wetlands of varying hydroperiod and vegetation physiognomy have been demonstrated to support different assemblages of plant and animal life (Buhlmann and others, 1999;Battle and Golladay, 2001; Liner and others, 2008). For disturbancemaintained communities, prescribed burns (and in some cases canopy removal) may be required to preserve herbaceous habitat (Martin, 2006; Martin and Kirkman, 2009). 


\section{Knowledge Gaps}

Effective management and conservation require additional research to fill knowledge gaps about karst-depression wetlands as landforms and as ecosystems. In contrast to larger and more geographically continuous coastal and alluvial wetlands, the small size and scattered distribution of karst-depression wetlands have limited research on the hydrology and biology of these ecosystems (Sutter and Kral, 1994). Regional inventories of karst-depression wetlands are still incomplete and require hydrogeomorphic and ecological assessments in order to fully characterize the diversity of existing karst-depression wetlands (Kirkman and others, 1999).

Hydrologic regimes vary widely among karst-depression wetlands, and the interactions between geomorphology, hydrologic regime, and community structures remain poorly understood (Kirkman and others, 1999). Although the ecological importance of these hydrologic regimes is generally accepted, current understanding of ecohydrology in karst-depression wetlands is based on a small number of studies clustered in a few areas, with little consistency regarding objectives, methods, or approaches and with a tendency toward description and speculation rather than quantitative evaluation of hypotheses. For example, Hendricks and Goodwin (1952) reported weekly surface-water and groundwater levels along with relative abundance of plant species for 13 ponds within the Dougherty Plain of southwest Georgia, but did not connect spatial patterns in vegetation to hydrologic observations.

In particular, the dynamics of hydrologic connectivity to surface water and groundwater require further study in karstdepression wetlands (Kirkman and others, 2012). Baseline characterization of these dynamics is required in order to assess possible future alterations due to climate change or land-use change. The interaction of these dynamics with evapotranspiration and their combined effects on key components of the hydrologic regime (such as hydroperiod, inundation depth, and depth to groundwater during dry periods) require further study in order to predict and evaluate possible hydrologic changes. Conservation strategies require an understanding of these interacting factors. For example, while traditional conservation approaches that are focused on the wetland and a surrounding buffer area may be acceptable for wetlands with primarily surface-water connections, conservation of wetlands with extensive groundwater connection likely requires strategies encompassing entire aquifers (Sutter and Kral, 1994). Because hydrologic regime strongly regulates vegetation communities in karst-depression wetlands, long-term directional changes to key components of the hydrologic regime have the potential to destabilize community dynamics, emphasizing the importance of quantifying hydrologic indicators and their ecological consequences (Wolfe and others, 2004).

Additionally, gaps in knowledge about the community ecology of these ecosystems need to be addressed. For example, the dynamics of disjunct species in karst-depression wetlands, and particularly the direction and ecological controls on succession, have not been well studied (Wolfe, 1996b). Historical fire regimes and the role of seed banks in rare plant communities are not fully understood in these ecosystems (Sutter and Kral, 1994). Quantification is needed for invasive exotic species, as well as improved understanding of the conditions facilitating invasions (Kirkman and others, 1999). Restoration of degraded karst-depression wetlands requires the identification of reference sites and the determination of restoration endpoints, both of which can be difficult in regions where anthropogenic alteration of wetlands has been widespread (Kirkman and others, 1999; Kirkman and others, 2000; Martin, 2006).

Conservation of rare and vulnerable species within karst-depression wetlands requires improved understanding of the particular life cycles and habitat requirements of each species (Semlitsch and Bodie, 2003). For example, the stresstolerance thresholds of narrowly endemic plant species require further study to enable effective conservation (Knox, 1997). Identification of source and sink populations of key amphibians within karst wetland complexes, as well as quantification of upland buffer habitat requirements, is required to inform conservation approaches for karst wetland fauna (Sutter and Kral, 1994; Buhlmann and others, 1999). Additional taxa that are dependent upon karst-depression wetland habitatespecially invertebrates, algae, and fungi-are likely waiting to be discovered (Kirkman and others, 1999).

\section{Possible Ecological Effects from Climate Change}

Global climate change has the potential to substantially alter karst-depression wetlands, especially through its effects on precipitation and evapotranspiration patterns and through consequent effects on groundwater levels. Wolfe (1996b) argued that internal relief and interaction with the groundwater system are likely to affect the sensitivity to environmental change of karst-depression wetlands. Broad, shallow, perched systems may be relatively resilient because water depths and internal drainage are respectively constrained by topography and impermeable substrate. Conversely, narrow, deep depressions that are closely coupled to the groundwater system may be vulnerable to prolonged, deep ponding should groundwater levels increase or to wetland degradation through hydroperiod reduction should groundwater levels decrease (Wolfe, 1996b).

Such ecohydrologic vulnerability is exemplified by the effects of climate change on tree regeneration and mortality in Sinking Pond, an 87-acre (approximately 35-hectare) Highland Rim compound sink with a depth of approximately 11.5 feet (about 3.5 meters). In a study of the population dynamics of Quercus lyrata in Sinking Pond, McCarthy and Evans (2000) and Wolfe and others (2004) provided evidence that these changes may already be underway. This research demonstrated a suppression of recruitment possibly constituting regeneration failure: Q. lyrata saplings and young adults were found to be generally absent in areas of ponding depth greater than about 
1.5 feet (roughly 0.5 meter), despite concentrations of seedlings and mature trees in these areas, and were instead confined to a small area of relatively shallow ponding depth. Dendrochronological analysis showed a marked suppression of recruitment in moderately to deeply flooded areas after 1970, corresponding to an increase in ponding durations across ponding-depth classes and to increased regional and local precipitation after 1970. Wolfe and others (2004) evaluated the hypothesis that these hydrologic and ecologic changes were linked to localized human activities within the Sinking Pond basin, such as direct modifications to drainage, land-use changes within the basin, or impoundment of surrounding catchments (see appendix B in Wolfe and others, 2004); however, evidence was lacking to support any of these explanations. Thus, the observed recruitment failure was attributed to an increase in ponding duration over time resulting from increased regional precipitation. This adverse effect from climate change will likely affect not only the population of Q. lyrata in Sinking Pond but also other members of the pond's globally rare community.

\section{References}

Baskin, J., Chester, E., and Baskin, C., 1997, Special paperForest vegetation of the Kentucky karst plain (Kentucky and Tennessee)-Review and synthesis: Journal of the Torrey Botanical Society, v. 124, no. 4, p. 322-335.

Battle, J. and Golladay, S., 2001, Water quality and macroinvertebrate assemblages in three types of seasonally inundated limesink wetlands in southwest Georgia: Journal of Freshwater Ecology, v. 16, no. 2, p. 189-207.

Beck, B., and Arden, D., 1984, Karst hydrogeology and geomorphology of the Dougherty Plain, southwest Georgia, guidebook number 26: Tallahassee, Fla., Southeastern Geological Society, 63 p.

Brahana, J., and Bradley, M., 1986, Preliminary delineation and description of the regional aquifers of TennesseeHighland Rim aquifer system: U.S. Geological Survey Water-Resources Investigations Report 82-4054, 38 p.

Buhlmann, K., Mitchell, J., and Smith, L., 1999, Descriptive ecology of the Shenandoah Valley sinkhole pond system in Virginia: Banisteria, v. 13, p. 23-51.

Chester, E., and Ellis, W., 1989, Plant communities of northwestern Middle Tennessee: Journal of the Tennessee Academy of Science, v. 64, no. 3, p. 75-78.

Cowardin, L., Carter, V., Golet, F., and LaRoe, E., 1979, Classification of wetlands and deepwater habitats of the United States: U.S. Department of the Interior, Fish and Wildlife Service, FWS/OBS-79/31.

Cranfill, R., 1991, Flora of Hardin County, Kentucky: Castanea, v. 56, no. 4, p. 228-267.
Delcourt, H., 1979, Late quaternary vegetation history of the eastern Highland Rim and adjacent Cumberland Plateau of Tennessee: Ecological Monographs, v. 49, no. 3, p. 255-280.

DeSelm, H., 1973, Six potential National Natural Landmarks in Tennessee-Report prepared for the U.S. National Park Service, Southeast Region, Atlanta, Ga.: Knoxville, Tenn., University of Tennessee, NPS--CS5000 31582.

DeSelm, H., 1990, Flora and vegetation of some barrens of the eastern Highland Rim of Tennessee: Castanea, v. 55, no. 3, p. 187-206.

Downey, D.M., Wirtz, S., Kruer, K.R., and Douglas, S.P., 1999, Water chemistry assessment of the Shenandoah Valley sinkhole ponds in Virginia: Banisteria, no. 13, p. 53-65.

Drew, M.B., Kirkman, L.K., and Gholson, A.K., 1998, The vascular flora of Ichauway, Baker County, GeorgiaA remnant longleaf pine/wiregrass ecosystem: Castanea, v. 63 , no. 1, p. 1-24.

Edwards, A., and Weakley, A., 2001, Population biology and management of rare plants in depression wetlands of the southeastern Coastal Plain, USA: Natural Areas Journal, v. 21 , no. 1, p. $12-35$.

Ellis, W., and Chester, E., 1989, Upland swamps of the Highland Rim of Tennessee: Journal of the Tennessee Academy of Science, v. 64, no. 3, p. 97-101.

Fenneman, N., 1938, Physiography of the eastern United States: New York, McGraw-Hill, 714 p.

Fenneman, N., and Johnson, D., 1946, Physical divisions of the United States: U.S. Geological Survey map prepared in cooperation with the Physiographic Commission, scale $1: 7,000,000$.

Fleming, G., and Patterson, K., 2012, Natural communities of Virginia-Ecological groups and community types: Richmond, Va., Virginia Department of Conservation and Recreation, Division of Natural Heritage, $36 \mathrm{p}$.

Fleming, G., Patterson, K., Taverna, K., and Couling, P., 2012, The natural communities of Virginia - Classification of ecological community groups, second approximation, version 2.5: Richmond, Va., Virginia Department of Conservation and Recreation, Division of Natural Heritage.

Fleming, W., Pullin, B., and Swineford, D., 1984, Population trends and environmental contaminants in herons in the Tennessee Valley, 1980-81: Colonial Waterbirds, v. 7, p. 63-73.

Fleming, G., and Van Alstine, N., 1999, Plant communities and floristic features of sinkhole ponds and seepage wetlands in southeastern Augusta County, Virginia: Banisteria, v. 13, p. 67-94. 
Folkerts, G., 1997, Citronelle ponds-Little-known wetlands of the central Gulf Coastal Plain, USA: Natural Areas Journal, v. 17, p. 6-16.

Ford, D., and Williams, P., 1989, Karst geomorphology and hydrology: London, Unwin Hyman, Ltd., 601 p.

Franklin, M.A., and Finnegan, J.T., 2006, Natural Heritage Program list of rare plant species of North Carolina 2006: Raleigh, N.C., North Carolina Natural Heritage Program, Office of Conservation and Community.

Golladay, S., Entrekin, S., and Taylor, B., 1999, Forested limesink wetlands of southwest Georgia - Invertebrate habitat and hydrologic variation, in Batzer, D., Rader, R., and Wissinger, S., eds., Invertebrates in freshwater wetlands of North America: John Wiley \& Sons, p. 197-216.

Golladay, S.W., Taylor, B.W., and Palik, B.J., 1997, Invertebrate communities of forested limesink wetlands in southwest Georgia, USA - Habitat use and influence of extended inundation: Wetlands, v. 17, no. 3, p. 383-393.

Grant, J., Mayor, A., Lambdin, P., and Wiggins, G., 2003, New species records and incidence of bark beetles and ambrosia beetles (Coleoptera: Scolytidae) from the barrens of middle Tennessee, USA: Natural Areas Journal, v. 22, p. 278-283.

Greear, P., 1967, Composition, diversity, and structure of the vegetation of some natural ponds in northwest Georgia: University of Georgia, Ph.D. dissertation.

Hannan, R., and Lassetter, J., 1982, The vascular flora of the Brodhead Swamp Forest, Rockcastle County, Kentucky: Transactions of the Kentucky Academy of Sciences, v. 43, no. 1-2, p. 43-49.

Harper, E.B., Rittenhouse, T.A.G., and Semlitsch, R.D., 2008, Demographic consequences of terrestrial habitat loss for pool-breeding amphibians-Predicting extinction risks associated with inadequate size of buffer zones: Conservation Biology, v. 22, no. 5, p. 1205-1215.

Haugh, C.J., 2006, Hydrogeology and simulation of groundwater flow at Arnold Air Force Base, Coffee and Franklin Counties, Tennessee-2002 update: U.S. Geological Survey Scientific Investigations Report 2006-5157, 16 p.

Hendricks, E., and Goodwin, M., 1952, Water-level fluctuations in limestone sinks in southwestern Georgia: Washington, D.C., U.S. Department of the Interior, Geological Survey Water-Supply Paper 1110-E.

Hess, J., Wells, S., Quinlan, J., and White, W., 1989, Hydrogeology of the south-central Kentucky karst: Karst Hydrology, p. 15-63.
Hicks, D., Krause, R., and Clarke, J., 1981, Geohydrology of the Albany area, Georgia: Atlanta, Ga., Georgia Department of Natural Resources, Environmental Protection Division, Georgia Geologic Survey.

Hill, A., 2007, Monitoring and modeling the hydrology of a forested sinkhole wetland on the Tennessee Highland Rim: Tennessee Technological University, Ph.D. dissertation, $212 \mathrm{p}$.

Hill, A., and Neary, V., 2007, Estimating evapotranspiration and seepage for a sinkhole wetland from diurnal surface water cycles: Journal of the American Water Resources Association, v. 43, no. 6, p. 1373-1382.

Hill, A., and Neary, V., 2012, Annual water budgets for a seasonally inundated sinkhole wetland: Wetlands, v. 32, no. 5, p. 963-974.

Hill, A., Neary, V., and Morgan, K., 2006, Hydrologic modeling as a development tool for HGM functional assessment models: Wetlands, v. 26, no. 1, p. 161-180.

Hinkle, K.R., and Sterrett, R.M., 1976, Rockingham County groundwater-Present conditions and prospects: Richmond, Va., Commonwealth of Virginia State Water Control Board, Bureau of Water Control Management.

Hinkle, K.R., and Sterrett, R.M., 1978, Groundwater resources of Augusta County, Virginia: Richmond, Va., Commonwealth of Virginia State Water Control Board.

Hollyday, E.F., and Hileman, G.E., 1996, Hydrogeologic terranes and potential yield of water to wells in the Valley and Ridge Physiographic Province in the eastern and southeastern United States: U.S. Geological Survey Professional Paper 1422-C, 38 p.

Homoya, M., and Hedge, C., 1985, The upland sinkhole swamps and ponds of Harrison County, Indiana: Proceedings of the Indiana Academy of Science, v. 92, p. 383-388.

Johnson, G., Zimmerman, T., Lindsey, B., and Gross, E., 2011, Factors affecting groundwater quality in the Valley and Ridge aquifers, eastern United States, 1993-2002: U.S. Geological Survey Scientific Investigations Report 2011-5115, 70 p.

Karl, T.R., and Knight, R.W., 1998, Secular trends of precipitation amount, frequency, and intensity in the United States: Bulletin of the American Meteorological Society, v. 79, no. 2, p. 231-241.

Kirkman, L.K., Goebel, P.C., West, L., Drew, M.B., and Palik, B.J., 2000, Depressional wetland vegetation typesA question of plant community development: Wetlands, v. 20 , no. 2 , p. $373-385$. 
Kirkman, L., Golladay, S., Laclaire, L., and Sutter, R., 1999, Biodiversity in southeastern, seasonally ponded, isolated wetlands-Management and policy perspectives for research and conservation: Journal of the North American Benthological Society, v. 18, no. 4, p. 553-562.

Kirkman, L., Smith, L., and Golladay, S., 2012, Southeastern depressional wetlands, in Batzer, D., and Baldwin, A., eds., Wetland habitats of North America-Ecology and conservation concerns: Berkeley, Calif., University of California Press, p. 203-215.

Knox, J., 1997, A nine year demographic study of Helenium virginicum (Asteraceae), a narrow endemic seasonal wetland plant: Journal of the Torrey Botanical Society, v. 124 , no. 3 , p. 236-245.

Liner, A.E., Smith, L.L., Golladay, S.W., Castleberry, S.B., and Gibbons, J.W., 2008, Amphibian distributions within three types of isolated wetlands in southwest Georgia: The American Midland Naturalist, v. 160, no. 1, p. 69-81.

Love, T., Williams, L., Proffitt, W., Epley, I., and Elder, J., 1956, Soil survey of Coffee County, Tennessee: U.S. Department of Agriculture, Soil Conservation Service, Series 1956, no. 5.

Martin, K., 2006, Restoration of fire-dependent depression wetlands: University of Georgia, Masters thesis.

Martin, K., and Kirkman, L., 2009, Management of ecological thresholds to re-establish disturbance-maintained herbaceous wetlands of the south-eastern USA: Journal of Applied Ecology, v. 46, no. 4, p. 906-914.

McCabe, G.J., and Wolock, D., 2002, A step increase in streamflow in the conterminous United States: Geophysical Research Letters, v. 29, no. 24, p. 2185.

McCarthy, S., and Evans, J., 2000, Population dynamics of overcup oak (Quercus lyrata) in a seasonally flooded karst depression: Journal of the Torrey Botanical Society, v. 127, no. 1, p. 9-18.

McKinney, L., 1989, Vegetation of the Eastern Highland Rim of Tennessee: Journal of the Tennessee Academy of Science, v. 64, no. 3, p. 145-147.

Miller, B., 1995, An investigation and assessment of rare, threatened, and endangered fauna and their habitats on Arnold Air Force Base, Coffee and Franklin Counties, Tennessee-Amphibian and reptile survey: Murfreesboro, Tenn., Middle Tennessee State University.

Miller, B.T., Lamb, J.W., and Miller, J.L., 2005, The herpetofauna of Arnold Air Force Base in the Barrens of southcentral Tennessee: Southeastern Naturalist, v. 4, no. 1, p. 51-62.
Miller, J., 1986, Hydrogeologic framework of the Floridan aquifer system in Florida and in parts of Georgia, Alabama, and South Carolina: U.S. Geological Survey Professional Paper 1403-B, 91 p.

Moler, P., and Franz, R., 1987, Wildlife values of small, isolated wetlands in the southeastern Coastal Plain, in Proceedings of the Third Southeastern Nongame and Endangered Wildlife Symposium: Atlanta, Ga., Georgia Department of Natural Resources, p. 234-241.

NatureServe, 2015, NatureServe Explorer-An online encyclopedia of life [web application], ver. 7.1, accessed October 7, 2015, at http://www.natureserve.org/explorer.

Niemiller, M., 2005, The herpetofauna of the upper Duck River watershed in Coffee County, Tennessee: Journal of the Tennessee Academy of Science, v. 80, no. 1, p. 6-12.

Nuttle, W., 1997, Measurement of wetland hydroperiod using harmonic analysis: Wetlands, v. 17, no. 1, p. 82-89.

O’Driscoll, M.A., and Parizek, R.R., 2003, The hydrologic catchment area of a chain of karst wetlands in central Pennsylvania, USA: Wetlands, v. 23, no. 1, p. 171-179.

O’Driscoll, M.A., and Parizek, R.R., 2008, Geological controls on seasonal-pool hydroperiod in a karst setting: Wetlands, v. 28, no. 4, p. 1004-1017.

Opsahl, S.P., 2005, Organic carbon composition and oxygen metabolism across a gradient of seasonally inundated limesink and riparian wetlands in the southeast Coastal Plain, USA: Biogeochemistry, v. 76, no. 1, p. 47-68.

Palik, B.J., Goebel, P.C., Kirkman, L.K., and West, L., 2000, Using landscape hierarchies to guide restoration of disturbed ecosystems: Ecological Applications, v. 10, no. 1, p. 189-202.

Patterson, W., 1989, Vegetation and soils of the Sinking Pond area, Coffee County, Tennessee. University of Tennessee, Thesis.

Pullin, P., 1990, Size and trends of wading bird populations in Tennessee during 1977-1988: The Migrant, v. 61, no. 4, p. 95-104.

Reed, J., Bryant, B., and Hack, J., 1963, Origin of some intermittent ponds on quartzite ridges in western North Carolina: The Geological Society of America Bulletin, v. 74, no. 9, p. 1183-1188.

Roberts, T., Morgan, K., Hill, A., Cripps, R., and Neary, V., 2004, Hydrogeomorphic classification and assessment of depression and flat wetlands on the Tennessee Highland Rim: Nashville, Tenn., State of Tennessee Department of Transportation. 
Ryder, R.T., 1987, Oil and gas resources of the Cincinnati Arch, Ohio, Indiana, Kentucky, and Tennessee: U.S. Geological Survey Open-File Report 87-450Y, 30 p.

Semlitsch, R., 1998, Biological delineation of terrestrial buffer zones for pond breeding salamanders: Conservation Biology, v. 12, no. 5, p. 1113-1119.

Semlitsch, R.D., and Bodie, J.R., 2003, Biological criteria for buffer zones around wetlands and riparian habitats for amphibians and reptiles: Conservation Biology, v. 17, no. 5, p. 1219-1228.

Semlitsch, R.D., and Jensen, J.B., 2001, Core habitat, not buffer zone: National Wetlands Newsletter, v. 23, no. 4, p. 4-6.

Smith, L.L., Steen, D.A., Stober, J.M., Freeman, M.C., Steve, W., Conner, L.M., and Cochrane, J., 2006, The vertebrate fauna of Ichauway, Baker County, GA: Southeastern Naturalist, v. 5, no. 4, p. 599-620.

Sorrie, B., 2012, Identification, distribution, and habitat of needle-leaved Hypericum (Hypericaceae) in the southeastern United States: Phytoneuron, v. 76, p. 1-14.

Sorrie, B., and Weakley, A., 2001, Coastal Plain vascular plant endemics_-Phytogeographic patterns: Castanea, v. 66 , no. 1, p. $50-82$.

Sutter, R., and Kral, R., 1994, The ecology, status, and conservation of two non-alluvial wetland communities in the south Atlantic and eastern Gulf Coastal Plain, USA: Biological Conservation, v. 68, p. 235-243.

Torak, L., Davis, G., Strain, G., and Herndon, J., 1993, Geohydrology and evaluation of water-resource potential of the Upper Floridan Aquifer in the Albany area, southwestern Georgia: U.S. Geological Survey Water-Supply Paper 2391, 59 p.

Townsend, J., 2015, Natural heritage resources of VirginiaRare plants: Richmond, Va., Virginia Department of Conservation and Recreation, Division of Natural Heritage, Natural Heritage Technical Report 15-10, 60 p.

Unterreiner, G., 2006, Hydrogeology of Harrison County, Indiana: Indianapolis, Ind., State of Indiana Department of Natural Resources, Division of Water, Bulletin 40.

U.S. Environmental Protection Agency, 2013, Level III and IV ecoregions of the continental United States: U.S. Environmental Protection Agency, National Health and Environmental Effects Research Laboratory, scale 1:3,000,000, accessed October 28, 2015, at http://www.epa.gov/wed/ pages/ecoregions/level_iii_iv.htm.
Vlach, J., 1999, An assessment of arthropod diversity using nine collection methods at Sinking Pond-A registered natural landmark in Coffee County, Tennessee: The University of Tennessee, Masters Thesis, $120 \mathrm{p}$.

Vlach, J., Lambdin, P., Dilling, C., and Grant, J., 2010, Diversity of the insect fauna within the unique sinking pond habitat in Middle Tennessee: Journal of the Tennessee Academy of Science, v. 85, no. 3, p. 62-86.

White, W.B., 1988, Geomorphology and hydrology of karst terrains: New York, Oxford University Press, 464 p.

Whittecar, G.R., and Lawrence, J.R., 1999, Hydrology and geomorphology of Green Pond-A high-elevation depressional wetland in the Blue Ridge of Virginia: Banisteria, v. 13, p. 149-159.

Wiggins, G., and Etnier, D., 2001, New Tennessee records for Wormaldia shawnee, Oligostomis ocelligera, Oligostomis pardalis, and Pycnopsyche rossi (Trichoptera): Entomological News, v. 112, no. 3, p. 187-190.

Wiggins, G.J., Grant, J.F., and Lambdin, P.L., 2007, Diversity of darkling beetles (Coleoptera: Tenebrionidae) from Arnold Air Force Base in the Barrens of the Eastern Highland Rim, Tennessee: Natural Areas Journal, v. 27, no. 1, p. 66-71.

Wolfe, W.J., 1996a, Hydrology and tree-distribution patterns of karst wetlands at Arnold Engineering Development Center, Tennessee: U.S. Geological Survey Water-Resouces Investigations Report 96-4277, 46 p.

Wolfe, W.J., 1996b, Karst wetlands of the BarrensGeomorphic control of wetland hydrology and plant distribution on the Highland Rim of Tennessee: Clark University, Ph.D. Dissertation, 147 p.

Wolfe, W.J., Evans, J., McCarthy, S., Gain, W., and Bryan, B., 2004, Tree-regeneration and mortality patterns and hydrologic change in a forested karst wetland - Sinking Pond, Arnold Air Force Base, Tennessee: U.S. Geological Survey Water-Resources Investigations Report 03-4217, 62 p.

Wolfe, W.J., Haugh, C.J., Webbers, A., and Diehl, T.H., 1997, Preliminary conceptual models of the occurrence, fate, and transport of chlorinated solvents in karst regions of Tennessee: U.S. Geological Survey Water-Resources Investigations Report 97-4097, 80 p. 


\section{Chapter I. Riverscour Ecosystems}

\section{Introduction}

Riverscour ecosystems are a subset of a larger category of riparian corridors, an ecosystem category known to support unusually high biodiversity, especially for vascular plants, in many different environmental contexts and on several continents (Naiman and others, 1993). The high biodiversity of riparian corridors is maintained in part through disturbance regimes - which can include floods, fire, landslides, channel migration and torrents of debris - as well as by micro-scale heterogeneity of habitat characteristics such as topographic position, microclimate, and soil moisture levels (Naiman and others, 1993; Bailey and Coe, 2001; Rood and others, 2007). Riverscour ecosystems generally form within or near the channel shelf along high-gradient sections of medium- to large-order streams (fig. I-1). Riverscour ecosystems contain a number of diverse community types. Community composition is generally determined by the dynamic integration of factors such as biogeographic location, stream channel morphology, stream hydrology, gradient, sediment transport patterns, substrate chemistry, and habitat requirements of individual species (Hupp, 1983). The primary trait uniting the diverse communities in riverscour contexts is that ecological integrity is maintained largely by disturbance regimes based on periodic flood scouring. Following storm events, high-energy, sediment-laden flow redistributes stream sediments and physically damages riparian vegetation through mechanical abrasion (Ogle, 1992; Bailey and Coe, 2001; Murdock and others, 2007; Vanderhorst and others, 2007; Wolfe and others, 2007). This disturbance regime effectively excludes scourintolerant upland vegetation and thus maintains habitat for scour-adapted plants.

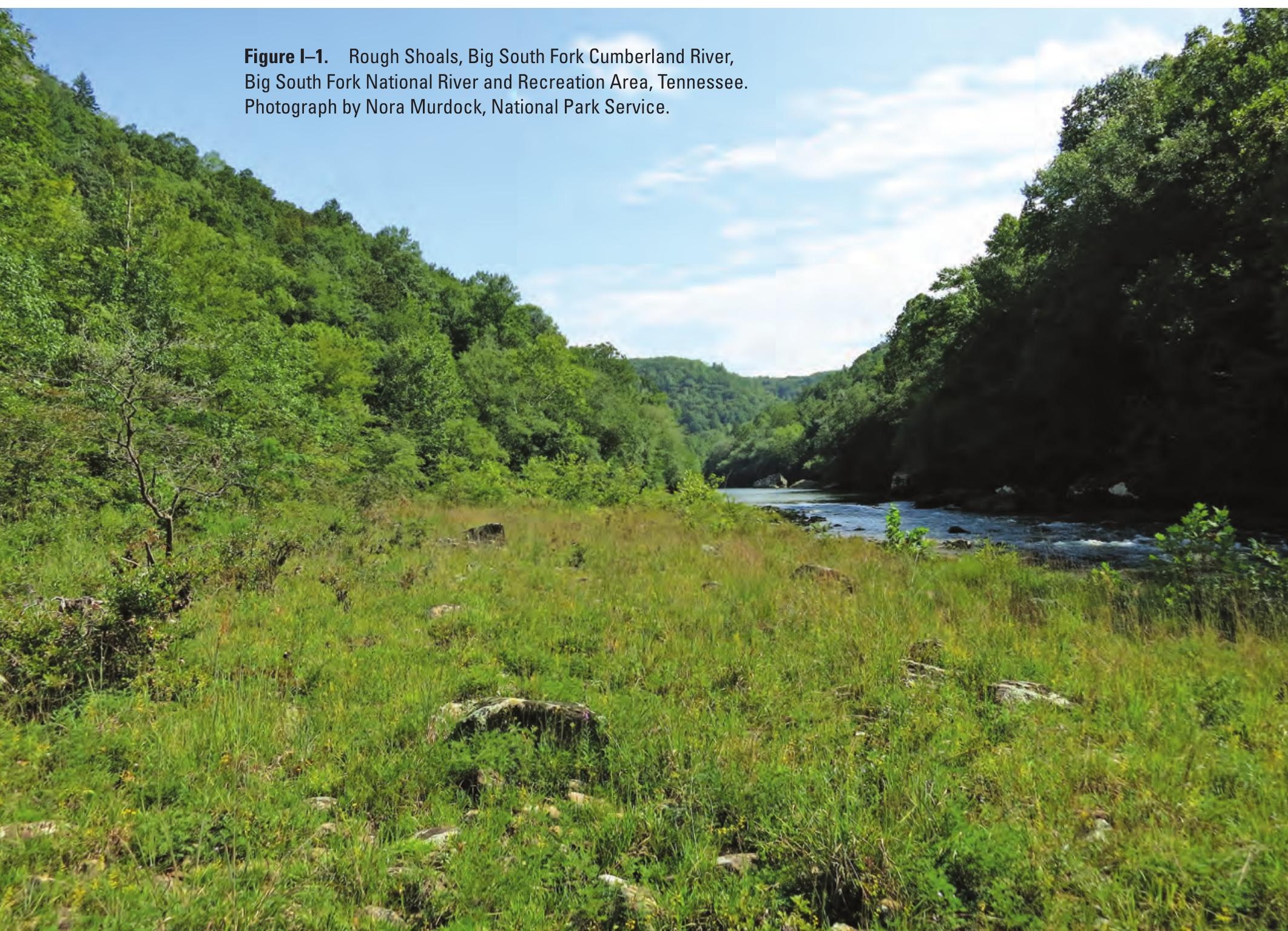




\section{Geographic Range}

Riverscour ecosystems are present in many geographic areas of the United States. Within the southeastern United States, various types of riverscour ecosystems have been described in several physiographic provinces (Fenneman and Johnson, 1946), including the Appalachian Plateaus, the Blue Ridge, the Interior Low Plateaus, the Valley and Ridge, and the Piedmont (Ogle, 1992; Vanderhorst and others, 2007, 2010). Riverscour habitats have been characterized and endemic species have been documented along several dozen streams (table I-1). Prominent research sites in riverscour ecosystems and their locations along streams are shown in figure I-2. Outside the southeastern United States, riverscour ecosystems have been described in a number of other locations in North America, including New England, the northern midAtlantic States, Alaska, and the Rocky Mountains (Westervelt and others, 2006; Rood and others, 2007; Mouw, 2009).

\section{Physical Geography}

Riverscour ecosystems may occupy discrete sites and (or) continuous linear zones along high-gradient sections of second- and higher-order streams (Ogle, 1992; Vanderhorst and others, 2007; Wolfe and others, 2007). Ecosystem development can occur on a variety of substrates, including bedrock (often partially exposed, with areas of thin soil or sediment) and aggregations of alluvial substrates ranging in size from boulders and cobble to gravel and sand. These rock particles may enter stream channels via mass wasting from cliffs that form the walls of river gorges or via debris flows down steep tributaries (Wolfe and others, 2007). Accretion of alluvial substrates into shoals or bars typically takes place in relatively stable positions where sediment-laden flow loses power, such as channel bends, major confluences, and zones of deflected flow from obstructions such as large non-alluvial boulders (Wolfe and others, 2007). Once alluvial bars begin

Table I-1. Selected streams supporting riverscour ecosystems within the southeastern United States.

[Stream names indicate rivers unless specified as creeks]

\begin{tabular}{|c|c|c|c|c|}
\hline State & & Streams & & References \\
\hline West Virginia & $\begin{array}{l}\text { Bluestone } \\
\text { Gauley } \\
\text { Monongahela } \\
\text { Shenandoah }\end{array}$ & $\begin{array}{l}\text { Buckhannon } \\
\text { Greenbrier } \\
\text { New } \\
\text { Tygart Valley }\end{array}$ & $\begin{array}{l}\text { Cheat } \\
\text { Meadow } \\
\text { Potomac }\end{array}$ & $\begin{array}{l}\text { Ogle (1991), Suiter and Evans (1999), } \\
\text { Mitchem (2004), Byers and others } \\
\text { (2007), Vanderhorst and others (2007, } \\
\text { 2010), Wells (2012) }\end{array}$ \\
\hline Pennsylvania & Delaware & Youghiogheny & & $\begin{array}{l}\text { Ogle (1991), Grund and Zimmerman } \\
\text { (2009), Zimmerman (2011) }\end{array}$ \\
\hline Virginia & $\begin{array}{l}\text { Guest } \\
\text { New } \\
\text { Pound } \\
\text { Russell Fork }\end{array}$ & $\begin{array}{l}\text { James } \\
\text { Passage Creek } \\
\text { Rappahannock } \\
\text { Shenandoah }\end{array}$ & $\begin{array}{l}\text { Maury } \\
\text { Potomac } \\
\text { Roanoke }\end{array}$ & $\begin{array}{l}\text { Hupp (1983), Ogle (1991), Belden and } \\
\text { others (2003), Steury and others } \\
\text { (2008), Fleming and Patterson (2012) }\end{array}$ \\
\hline Maryland & Monocacy & Potomac & & $\begin{array}{l}\text { Lea (2000), Vanderhorst and others } \\
\text { (2007), Wells (2012) }\end{array}$ \\
\hline North Carolina & $\begin{array}{l}\text { Cane } \\
\text { Little Tennessee } \\
\text { Roanoke }\end{array}$ & $\begin{array}{l}\text { Cheoah } \\
\text { New } \\
\text { South Toe }\end{array}$ & $\begin{array}{l}\text { Hominy Creek } \\
\text { Nolichucky } \\
\text { Yadkin }\end{array}$ & $\begin{array}{l}\text { Ogle (1991), Hutchens and others (2009), } \\
\text { Schafale (2012) }\end{array}$ \\
\hline Tennessee & $\begin{array}{l}\text { Abrams Creek } \\
\text { Clear Fork } \\
\text { Daddys Creek } \\
\text { Little } \\
\text { Obed }\end{array}$ & $\begin{array}{l}\text { Cane Creek } \\
\text { Clifty Creek } \\
\text { Duck } \\
\text { Little Tennessee } \\
\text { Ocoee }\end{array}$ & $\begin{array}{l}\text { Clear Creek } \\
\text { Cumberland } \\
\text { Hiwassee } \\
\text { Nolichucky } \\
\text { White Oak Creek }\end{array}$ & $\begin{array}{l}\text { Schmalzer (1989), Ogle (1991), Pyne } \\
\text { and Withers (1996), Major and others } \\
\text { (1999), Bailey and Coe (2001), Wolfe } \\
\text { and others (2007), U.S. Fish and Wild- } \\
\text { life Service (2011), Floden (2012) }\end{array}$ \\
\hline Kentucky & $\begin{array}{l}\text { Clear Fork } \\
\text { Kentucky } \\
\text { Red }\end{array}$ & $\begin{array}{l}\text { Cumberland } \\
\text { Kinniconick Creek } \\
\text { Rockcastle }\end{array}$ & $\begin{array}{l}\text { Green } \\
\text { New } \\
\text { Sinking Creek }\end{array}$ & $\begin{array}{l}\text { Meijer (1976), Medley and Wofford } \\
\text { (1980), Ogle (1991, 1992) Pyne } \\
\text { and Withers (1996), Bailey and Coe } \\
\text { (2001), Reed (2003), Taylor (2003) }\end{array}$ \\
\hline Georgia & Chattahoochee & Bear Creek & Rock Creek & Ogle (1991) \\
\hline Alabama & $\begin{array}{l}\text { Little } \\
\text { Cahaba Creek }\end{array}$ & $\begin{array}{l}\text { Black Warrior } \\
\text { (Locust Fork) } \\
\text { Cypress Creek }\end{array}$ & $\begin{array}{l}\text { Black Warrior } \\
\text { (Mulberry Fork) }\end{array}$ & Ogle (1991), Rinehart (2008) \\
\hline
\end{tabular}


to form, their structural stability may be enhanced by the imbricated (diagonally stacked) arrangement of larger boulders and by the protection from scouring provided by these boulders to interstitial deposits of cobbles, gravel, sand, and silt (Vanderhorst and others, 2007; Wolfe and others, 2007).
Once vegetation begins to colonize sites of alluvial deposition, a positive feedback loop can begin whereby plant roots stabilize the substrate and plant shoots filter and trap sediment, promoting further deposition of fine-grained suspended particles (Mouw, 2009).

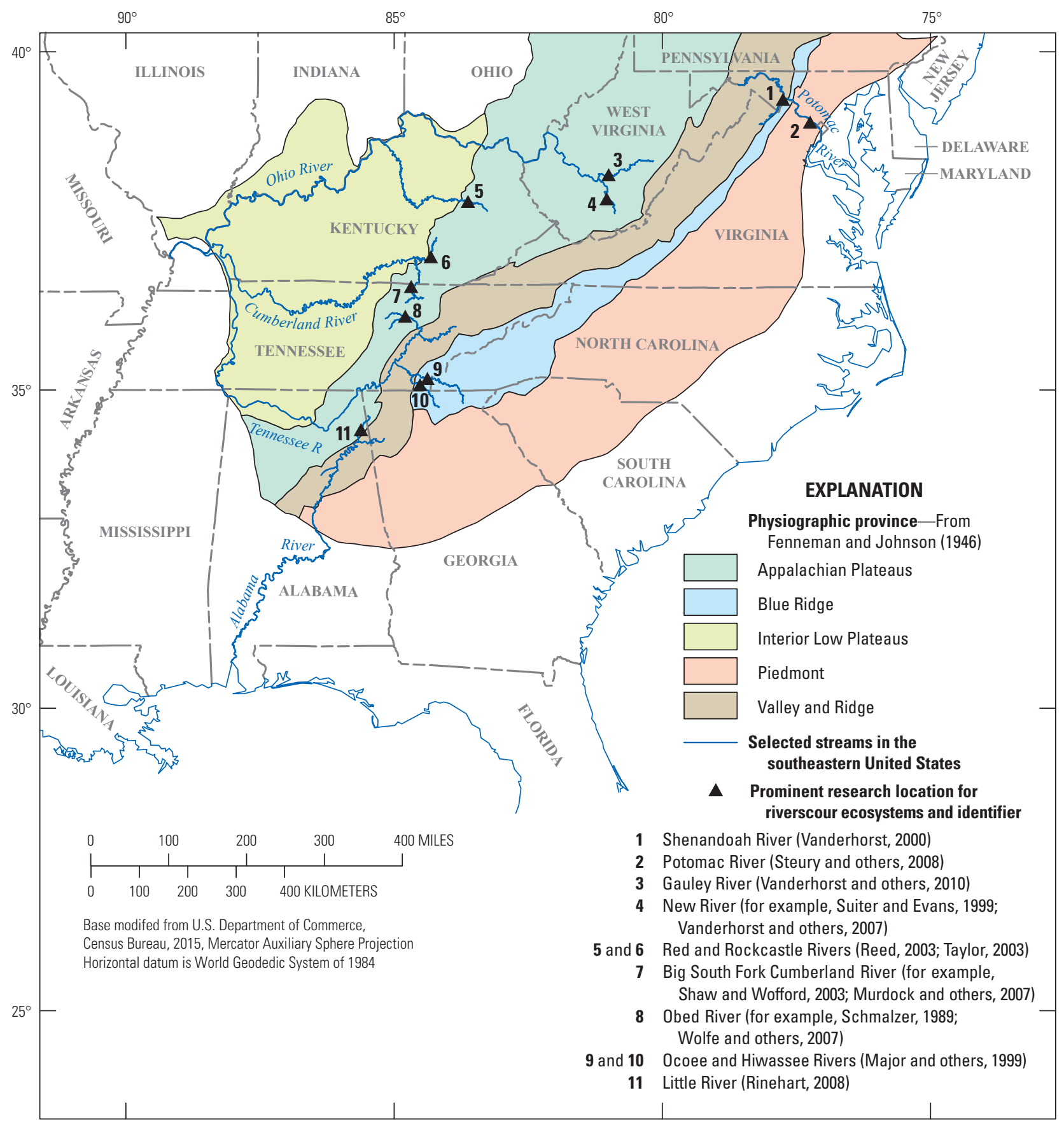

Figure I-2. Selected locations of riverscour ecosystems in the southeastern United States. 


\section{Stress and Disturbance Regimes}

The primary component of the abiotic stress regime for riverscour ecosystems is disturbance, namely the mechanical scouring from periodic high-energy floods (Vanderhorst and others, 2007; Wolfe and others, 2007). Depending on factors such as topography and basin substrate permeability, streamflow can respond rapidly to storm events in some cases. For example, in the Obed River and in the Big South Fork Cumberland River, flow has been documented to increase from 100 cubic feet per second (about 3 cubic meters per second) to 6,000 cubic feet per second (about 170 cubic meters per second) in a matter of hours following storm events, creating powerful flood-scouring effects on the entire riparian corridor (Murdock and others, 2007). High-energy flow of this type can be powerful enough to redistribute boulders and finer materials within the channel. For example, along some sections of the Obed River in Tennessee, hydraulic forces sufficient to transport 3-foot (approximately 1-meter) boulders along channel beds probably occur every few years (Wolfe and others, 2007).

Different magnitudes and intensities of floods produce different types of disturbances that affect riverscour communities. Medium-intensity floods may uproot individual trees but leave most other vegetation relatively intact, whereas high-intensity floods are capable of removing entire patches of vegetation and substantially restructuring alluvial substrates, resulting in the periodic redistribution of sediment and reconfigurations of channel morphology (Naiman and others, 1993; Bailey and Coe, 2001; Vanderhorst and others, 2007). The magnitude of the effects of disturbance regime on riverscour communities (frequency and depth of inundation, frequency and intensity of scouring) is generally proportional to proximity to the active channel, such that disturbance forms a gradient from the channel interior to the riparian forest edge (Hupp, 1983). Topographic variation within channels also affects scouring intensity. For example, island heads are generally more exposed to scouring, whereas areas immediately downstream of large boulders and other obstacles are more sheltered from the action of high-energy flows (Wolfe and others, 2007). At higher latitudes and elevations, winter ice scouring can be an additional disturbance factor (Westervelt and others, 2006; Byers and others, 2007; Rood and others, 2007; Mouw, 2009).

Disturbance from periodic scouring creates stress on vegetation in several ways. Direct effects include uprooting and damage to aboveground parts of plants. Scouring may also remove accumulated soil or sediment, resulting in thin soils. Soil shallowness in turn can limit soil water and nutrient availability, a set of factors that can be considered secondary components of the stress regime (Mitchem, 2004). Other stress factors include prolonged saturation and inundation for some microhabitats and, for others, xeric soil conditions caused by excessive drainage of coarse-textured substrates combined with moderate to full insolation from lack of canopy coverage (Vanderhorst and others, 2007; Wolfe and others, 2007).
Soil water availability can be highly variable spatially and temporally, such as in zones that are seasonally inundated in winter and spring and xeric in summer except for occasional flash floods (Bailey and Coe, 2001). Figure I-3 shows an example of riverscour habitat containing zones of exposed bedrock and standing water within topographic depressions. The combination of thin to absent soil, widely fluctuating hydrologic conditions, and high insolation is a set of stress regime components that some riverscour ecosystems share with other glade and outcrop ecosystems (Mitchem, 2004).

To maintain viable populations under the stress and disturbance regimes of the most heavily scoured zones of river channels, plant species commonly display specialized adaptations. These adaptations include the ability to recolonize rapidly following disturbance events, as well as dispersal methods that allow periodic scouring to spread seeds and vegetative propagules downstream (Bartgis, 1997; Bailey and Coe, 2001; Reed, 2003; Taylor, 2003; Wells, 2012). Tolerance of drought and (or) inundation are common adaptations, as are deep and strong anchor roots to minimize dislocation during floods (Ogle, 1991; Bailey and Coe, 2001). One interesting example is Podostemum ceratophyllum, a member of a family of tropical waterfall plants, which occupies riverscour habitats on the Red River, Little Tennessee River, and Big South Fork Cumberland River and other streams. This species uses specially adapted thalli to attach to rock surfaces with suction discs and glue (Meijer, 1976; Hutchens and others, 2009). A number of other riverscour-adapted plants die back in the fall and persist through the seasons with greatest flood likelihood (winter and early spring) as perennating rootstocks (Hupp, 1983).

This disturbance regime from flood scouring and the associated abiotic stress regime effectively excludes most mesic upland species, especially large trees (Vanderhorst and others, 2007; Wolfe and others, 2007). For riverscour-adapted plant taxa, tolerance of this stress and disturbance regime provides a competitive advantage over upland species as long as the disturbance regime remains active; without such a regime, these species, including many rare and endemic species, would likely be displaced by mesic competitors as part of the succession process (Schmalzer, 1989; Bailey and Coe, 2001; Wolfe and others, 2007). Because some riverscour species are shade-intolerant (Vanderhorst, 2000; Vanderhorst and others, 2007), overshading may be an important mechanism by which competitive displacement would occur in the absence of the flood-scour regime. Thus, a disturbance regime predicated on periodic inundation and flood scouring, which maintains a state of disequilibrium in riverscour ecosystems such that climatic or edaphic climax is rarely or never achieved, is critical for the maintenance of ecosystem integrity (Hupp, 1983).

The disturbance regime of riverscour ecosystems illustrates a broader concept linking high biodiversity with nonequilibrium situations where stochastic events periodically reduce populations and slow the process of competitive 


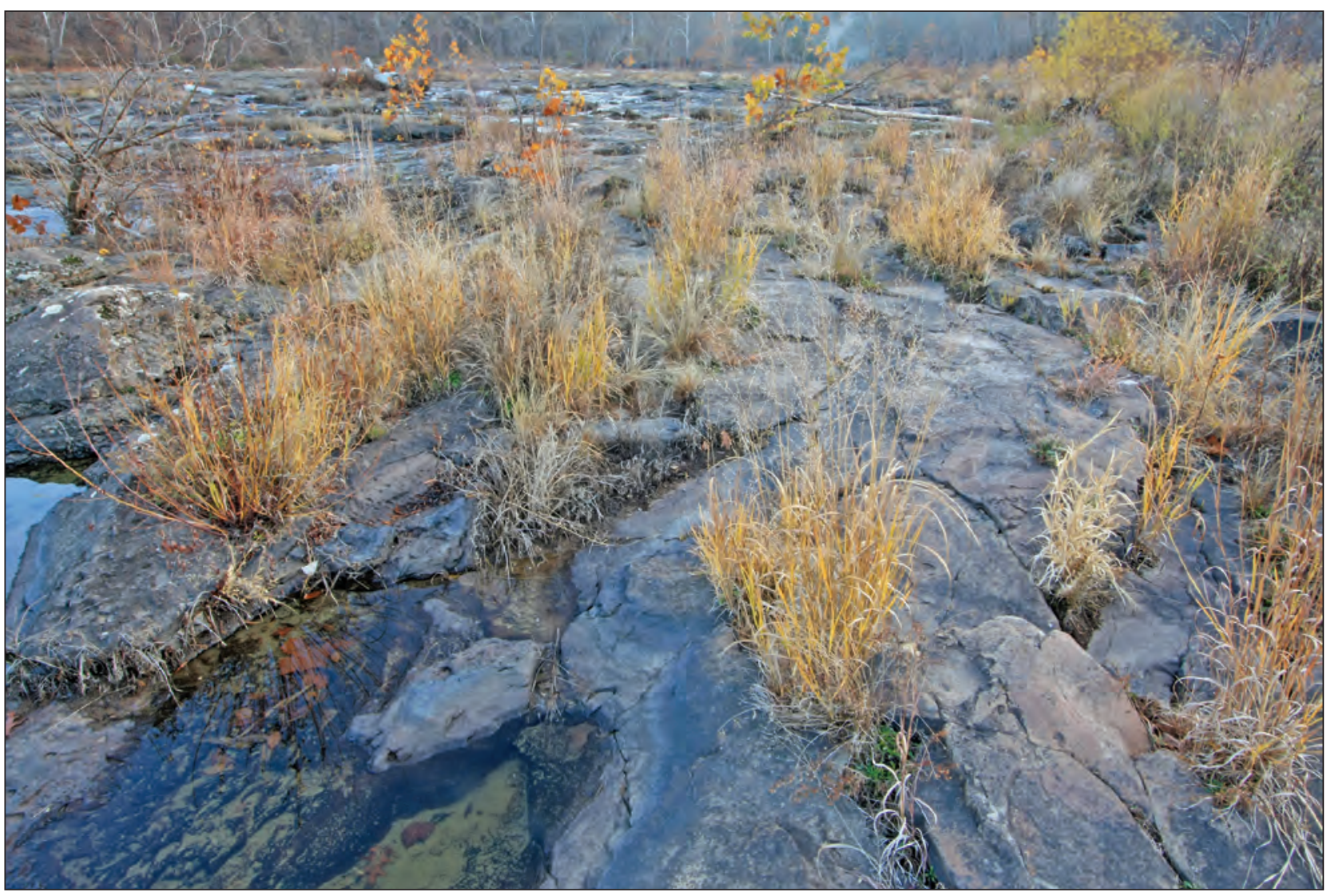

Figure I-3. Appalachian Riverside Flatrock Community, Sandstone Falls, New River, New River Gorge National River, Raleigh County, West Virginia. Photograph by Alan M. Cressler, U.S. Geological Survey.

exclusion (Huston, 1979; Naiman and others, 1993). Floristic studies have been conducted in areas containing riverscour habitat — as well as other riparian and upland ecosystems that are not subject to the scour-based disturbance regime - and have demonstrated the exceptional floristic richness and density of rare taxa supported by riverscour habitat. Examples include streams and adjacent land in the Big South Fork National River and Recreation Area (Bailey and Coe, 2001), the Obed Wild and Scenic River (Schmalzer and others, 1985), and the New River Gorge National River (Grafton and Grafton, 1980).

\section{Community Types and Vegetation Dynamics}

Within the broad category of riverscour ecosystems, a number of community types can be differentiated, varying in their topographic positions, soil moisture conditions (with micro-scale heterogeneity from xeric to saturated), substrate types, levels of canopy coverage (from a nearly closed canopy to the near absence of trees), herbaceous vegetation, levels of species diversity, and in the frequency and intensity of flood disturbance, among other factors (Schmalzer, 1989). The general gradient of disturbance along the channel cross section is hypothesized to account for observed gradients in community composition, from herbaceous vegetation nearest the active channel to woody shrubs and trees along the forest edge (Hupp, 1983). Often, community types form linear zoneseither continuous or, more often, patchily distributedparallel to the active channel (Hupp, 1983).

Considerable variability exists across riverscour community types in terms of scale and levels of geographic restriction. Some community types are relatively widespread, with distributions along multiple streams within a region, while others are known from only one stream or even from only one site. Levels of species diversity are also highly variable across riverscour community types. Some riverscour communities support high levels of plant-species richness, but others are largely dominated by a single species (for example Carex torta and Justicia americana), which may approximate monocultures (Vanderhorst and others, 2007). The community classification below uses colloquial names from the U.S. National Vegetation Classification (Jennings and others, 2009; Franklin and others, 2012) unless otherwise noted. 


\section{Appalachian/Northern Piedmont Riverside Outcrop Woodland}

This woodland community, termed the riverside flat rock plant community by Mitchem (2004) and riverside bedrock terrace woodland by Fleming and Patterson (2012), is ranked G1 and is ranked S1 in both Virginia and West Virginia (Vanderhorst and others, 2007; Fleming and Patterson, 2012). This community has been documented at two sandstone bedrock outcrop exposures along the New River (fig. I-4) near two major waterfalls, with soils that are shallow (average of 0.7 inch, or about 1.8 centimeters at one site), acidic ( $\mathrm{pH}$ approximately 3.9), highly organic, and nutrient-limited sands and sandy loams over bedrock (Suiter and Evans, 1999; Mitchem, 2004; Vanderhorst and others, 2007). Similar thinsoil communities on dolomite, calcareous shale, charnockite, and acidic schists and gneisses have been documented along high-gradient rivers in Virginia, including the Potomac, Shenandoah, and James Rivers (Belden and others, 2003; Fleming and Patterson, 2012). Soils are well drained, creating a relatively dry moisture regime. The mostly open canopy is dominated by Juniperus virginiana and Pinus virginiana with a diverse understory shrub and herb layer and a substantial component of mosses and lichens (Mitchem, 2004; Vanderhorst and others, 2007). Herbaceous species of this flatrock woodland community include Asplenium platyneuron, Juncus tenuis, and Hypericum gentianoides (Suiter and Evans, 1999). Within the New River Gorge National River, formation of this community is believed to have occurred following catastrophic flooding in the late 1800 s by primary succession on scoured bedrock; however, flooding is now rare, and the flood regime has been altered by construction of the Bluestone Dam in 1949 (Vanderhorst and others, 2007). The consequences of this flooding regime alteration, in terms of the successional dynamics and ultimate fate of this rare community, are unclear.

\section{Appalachian/Cumberland Sycamore-Birch Riverscour Woodland}

This woodland community is dominated by Platanus occidentalis, Betula nigra and Salix spp., is classified as a temporarily flooded woodland, and is ranked G3 and S3 in West Virginia (Belden and others, 2003; Vanderhorst and others, 2007). Similar, related community types include the Piedmont/Central Appalachian Sycamore-River Birch Scour Woodland and the Central Appalachian/Piedmont Bedrock Floodplain Woodland (Fleming and Patterson, 2012; Schafale, 2012). Sites of these related communities have been documented along the New River in West Virginia and the James, Potomac, and Maury Rivers in Virginia (Suiter and Evans, 1999; Belden and others, 2003; Vanderhorst and others, 2007; Steury and others, 2008). This community occupies zones that are subjected to frequent high-energy flooding sufficient to damage and remove most trees, resulting in the maintenance

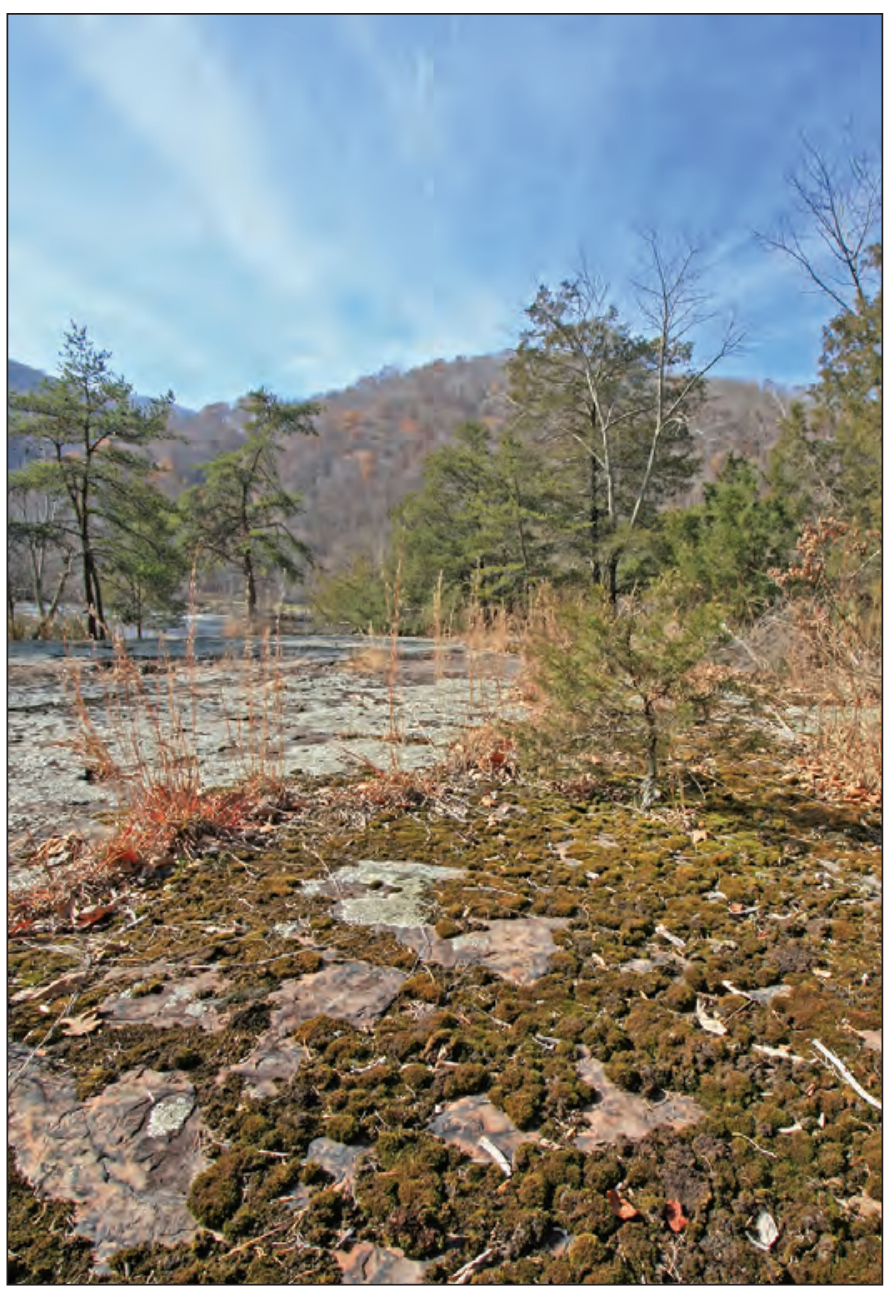

Figure I-4. Bedrock outcrop exposures along the New River at Camp Brookside, New River Gorge National River, Summers County, West Virginia. Photograph by Alan M. Cressler, U.S. Geological Survey.

of an open canopy (Belden and others, 2003; Vanderhorst and others, 2007). Trees are typically short and flood-battered, with the tallest trees often being the youngest, which have not yet been exposed to extreme flooding. The substrate is a mixture of cobbles and boulders with deposition of gravel and sand but little true soil development. The moisture regime is heterogeneous, with contrasting microsites of well-drained, coarse-textured alluvium and poorly drained areas of standing water caused by proximity to the water table and fluvial topography. Along sycamore-birch riverscour woodland areas are narrow, linear zones dominated by herbaceous annuals such as Eragrostis hypnoides, Lindernia dubia, Cyperus squarrosus, Acalypha rhomboidea, Chamaesyce humistrata, Fimbristylis autumnalis, and Panicum dichotomiflorum but which may also include herbaceous perennials such as Ludwigia palustris (Vanderhorst and others, 2007). Ecologically and spatially along the New River in West Virginia, the sycamore-birch riverscour woodland is intermediate between the riverscour prairie community, which is subjected to more frequent and intense scouring, and the sycamore-ash 
floodplain forest community, which is less affected by scouring (Vanderhorst and others, 2007). The shrub and herb layers are composed of flood-tolerant warm-season grasses and forbs with a large component of woody vines.

\section{Riverscour Prairie}

Riverscour prairie communities, such as those of the Appalachian and Interior Riverscour Barrens and Prairie Group, occupy the active channels of major rivers in zones intermediate between the low-water level and the bankfull level and are subjected to frequent, high-energy flooding and scouring (Vanderhorst and others, 2007). Unlike conditions in related riverscour woodland communities, the frequency and intensity of scouring in riverscour prairies are so high that most trees and other woody vegetation are either excluded entirely or they never reach mature stature (Vanderhorst, 2000; Vanderhorst and others, 2007). Soils are thin psamments composed of cobble and sand and are commonly restricted to small fissures in exposed bedrock or to narrow pockets between closely spaced boulders, with vegetation generally restricted to these limited areas of soil accumulation (Belden and others, 2003; Vanderhorst and others, 2007). Some microsites are excessively drained and xeric, whereas others are poorly drained due to their locations relative to the water table or to small depressions in bedrock (potholes) created by scouring. Because riverscour prairies are exposed to frequent, high-intensity flooding, dramatic restructuring of substrates (in the case of boulders and cobble) or complete scouring (in the case of bedrock) is possible, such that some instances of these communities are considered ephemeral. Riverscour prairie vegetation is primarily tall, warm-season grasses (Andropogon gerardii, Panicum virgatum, and Sorghastrum nutans) and prairie-associated forbs with a limited shrub component and low-growing vines (Vanderhorst, 2000; Belden and others, 2003; Vanderhorst and others, 2007). Riverscour prairie communities along the New River are ranked G3 and S1 in West Virginia (Vanderhorst and others, 2007). A riverscour prairie community type along the Cheat River in the Allegheny Mountains of West Virginia, dominated by Marshallia grandiflora, Rhododendron arborescens, Triantha glutinosa, and Platanthera flava var. herbiola, was classified as the Monongahela Barbara's-buttons Riverscour Prairie and ranked G1 and S1 by Byers and others (2007). In Virginia, riverscour prairies, termed "riverside prairies" by Belden and others (2003) and Fleming and Patterson (2012), are State-rare, and the few known instances are confined to the Potomac River Gorge west of Washington, D.C., and to sites along the James, Shenandoah, and Maury Rivers. Globally and State-rare subtypes of riverside prairies in Virginia include the Piedmont/Central Appalachian Riverside Outcrop Prairie (G1, S1), the Piedmont/Central Appalachian Bedrock Floodplain Prairie (G3, S2) and the Ridge and Valley Gravel-Wash Riverside Prairie (G2, S2). These associations were delineated based on substrate type, relative elevation, and moisture regime (Fleming and Patterson, 2012). Although the exact number of riverscour prairie association occurrences is not known, depending upon the specifics of community classification and occurrence delineation, riverscour prairies are probably limited to fewer than 100 occurrences in the southeastern United States (Vanderhorst and others, 2007).

\section{Twisted-Sedge Rocky Creekbed}

The twisted-sedge rocky creekbed community, also known as the Rocky Bar and Shore (Twisted Sedge Type), typically occupies boulder, cobble, and gravel bars within the channel shelves of high-gradient rivers and streams. This community consists of small patches of herbaceous vegetation strongly dominated by Carex torta, typically partially shaded by an open canopy of variable composition (Belden and others, 2003; Vanderhorst and others, 2007). The dominant community members, like Carex torta, are tough-rooted herbaceous perennials that are tolerant of high insolation and frequent inundation and scouring (Vanderhorst and others, 2007; Schafale, 2012). Along rivers in the Delaware Estuary, Westervelt and others (2006) describe a "willow river-bar shrubland" community type dominated by Carex torta along with Salix nigra and other willow saplings.

\section{American Water-Willow Cobble Bar (Justicia americana Herbaceous Vegetation)}

The American water-willow cobble bar community typically occupies the heads and tails of islands or deposition bars and in other positions within the stream channel with substrates including bedrock, boulders, cobble, gravel, and sand (Belden and others, 2003; Vanderhorst and others, 2007; Schafale, 2012). Except during periods of low flow, these locations are saturated or partially inundated; during high-flow periods, they are completely submerged (Steury and others, 2008). The vegetation is dominated by Justicia americana, an emergent aquatic herbaceous species. In more scour-prone sites, $J$. americana may form nearly homogenous stands. In more sheltered sites, other herbs such as Saururus cernuus and Schoenoplectus pungens may be present, along with scattered, flood-suppressed trees such as Acer saccharinum, Betula nigra, Fraxinus pennsylvanica, and Platanus occidentalis (Vanderhorst and others, 2007).

\section{Riverbank Annuals}

The riverbank annuals community occupies positions within the active channel shelf that are submerged for long periods and highly exposed to scouring, such as the lower parts of alluvial bars and eroded banks, with substrates of sand or silty sand (Vanderhorst and others, 2007). Because of the intensity of the disturbance regime, this community can be highly ephemeral and is dominated by fast-growing annuals 
and short-lived perennials such as Eragrostis hypnoides, Ludwigia palustris, Lindernia dubia, Eupatorium serotinum, and Cyperus squarrosus (Vanderhorst and others, 2007; Steury and others, 2008). The vegetation is almost exclusively herbaceous plants less than about 1.5 feet (roughly 0.5 meter) in height, and vegetation development is greatest in areas that are fully insolated and may only become exposed during the low-flow period from early summer to early autumn (Vanderhorst and others, 2007; Steury and others, 2008).

\section{Piedmont Riverscour Shrubland}

As described by Steury and others (2008), the Piedmont riverscour shrubland community is geographically restricted to the Piedmont region of Maryland and Virginia and specifically to sites along the high-gradient sections of the Potomac and Rappahannock Rivers that are relatively protected from scouring floods. This is primarily a woody shrub community, dominated by Carpinus caroliniana, Quercus rubra, Toxicodendron radicans, Nyssa sylvatica, Ulmus americana, Physocarpus opulifolius, Rhododendron periclymenoides, and Ilex decidua, with a sparse component of herbaceous graminoids and forbs (Steury and others, 2008).

\section{Potomac Gorge Riverside Outcrop Barren}

The Potomac Gorge riverside outcrop barren community type is believed to be endemic only to the Potomac River Gorge adjacent to the Potomac River in Virginia and Maryland. The community is found on massive, exposed outcrops of schist, migmatitic metagraywacke, and granodiorite bedrock (Steury and others, 2008). The sites where this community is present, typically at around 10 to 50 feet (about 3 to 15 meters) above mean river level, are only rarely scoured by catastrophic floods. Vascular vegetation is sparse and limited to microhabitats in crevices and depressions that accumulate fine gravel and organic matter. This community type supports some State-rare riverscouradapted species also found in other related riverscour habitats such as Baptisia australis and Solidago simplex var. racemosa (Steury and others, 2008).

\section{Scoured Riverine Bluff Prairie/Duck River Scour Prairie}

The scoured riverine bluff prairie community type, described by Pyne and Withers (1996), is apparently restricted to upstream-facing scoured limestone bluffs and bedrock shelves on the Duck River in the Central Basin of Tennessee and to related contexts on the Green and Kentucky Rivers in the Interior Low Plateaus of Kentucky.
The dominant vegetation consists of robust grasses such as Andropogon gerardii, Sorghastrum nutans, and Chasmanthium latifolium, with woody vines and shrubs such as Cornus amomum ssp. obliqua, Hypericum prolificum, and Toxicodendron radicans (Pyne and Withers, 1996).

\section{Hiwassee/Ocoee River Boulder Scour Vegetation}

The Hiwassee/Ocoee River boulder scour community, described by Major and others (1999), is apparently restricted to the Hiwassee and Ocoee Rivers within the Blue Ridge Physiographic Province of extreme southeastern Tennessee. Its herbaceous community is floristically similar to other riverscour prairie community types because it is dominated by perennial grasses and forbs such as Schizachyrium scoparium, Andropogon ternarius, Liatris microcephala, Coreopsis tripteris, Panicum species, Solidago species, and Agalinis species. This community is distinct, however, in that it supports the only known occurrences of Pityopsis ruthii, a G1-ranked and federally listed endangered species (Major and others, 1999; Thomson and Schwartz, 2006). A related community type, the Hiwassee/Ocoee River bedrock scour community, is composed of vegetation confined to crevices in scoured bedrock outcrops and is dominated by Schizachyrium scoparium, Schoenoplectus americanus, Juncus marginatus, Eupatorium serotinum, and a sparse assemblage of woody plants (Major and others, 1999). Both communities are ranked G2.

\section{Yadkin Falls Bedrock Scour Community}

The Yadkin Falls bedrock scour community is extremely limited geographically and is ranked G1 because it is apparently restricted to a limited section of the Yadkin River in the eastern Piedmont of North Carolina, where it transects mafic meta-volcanic bedrock (Schafale, 2012). This community type occupies exposed bedrock outcrops and is dominated by herbaceous species such as Schizachyrium scoparium. This community is distinct from all other riverscour communities in its particular geology, extreme geographic restriction (to one river), and by the occurrence of Solidago plumosa, a G1-ranked species that had been a candidate for endangered species status until its removal in 2013 (Schafale, 2012).

\section{Contributions to Regional Biodiversity}

Riparian corridors are highly dynamic ecosystems that can provide an exceptional diversity of habitats and ecological processes (Naiman and others, 1993). In the southeastern United States, riverscour communities contribute to regional biodiversity by supporting rare plant species, including several that are federally listed as endangered or threatened (fig. I-5). 


\section{Endemic and Biogeographically Disjunct Taxa}

Among riparian ecosystems, riverscour communities commonly support unusually high numbers of rare species. For example, in floristic studies within the Big South Fork National River and Recreation Area and in the Obed Wild and Scenic River, both on the Cumberland Plateau of Tennessee, Bailey and Coe (2001) found that 75 percent and 56 percent, respectively, of all rare plant species in riparian zones were restricted to scour-prone boulder and cobble bars. Many of these rare species constituted new additions to the flora of the counties in which they were found. In another floristic survey of the Big South Fork National River and Recreation Area, which included upland areas as well as riparian zones, Shaw and Wofford (2003) determined that nearly all of the species of conservation concern were found in "unique habitats," including riverscour areas. In addition to the many rare plant taxa supported by riverscour ecosystems, evidence supports their importance as habitat for rare animal species. For example, some American water-willow cobble bars provide habitat for globally rare dragonflies (Vanderhorst and others, 2007).
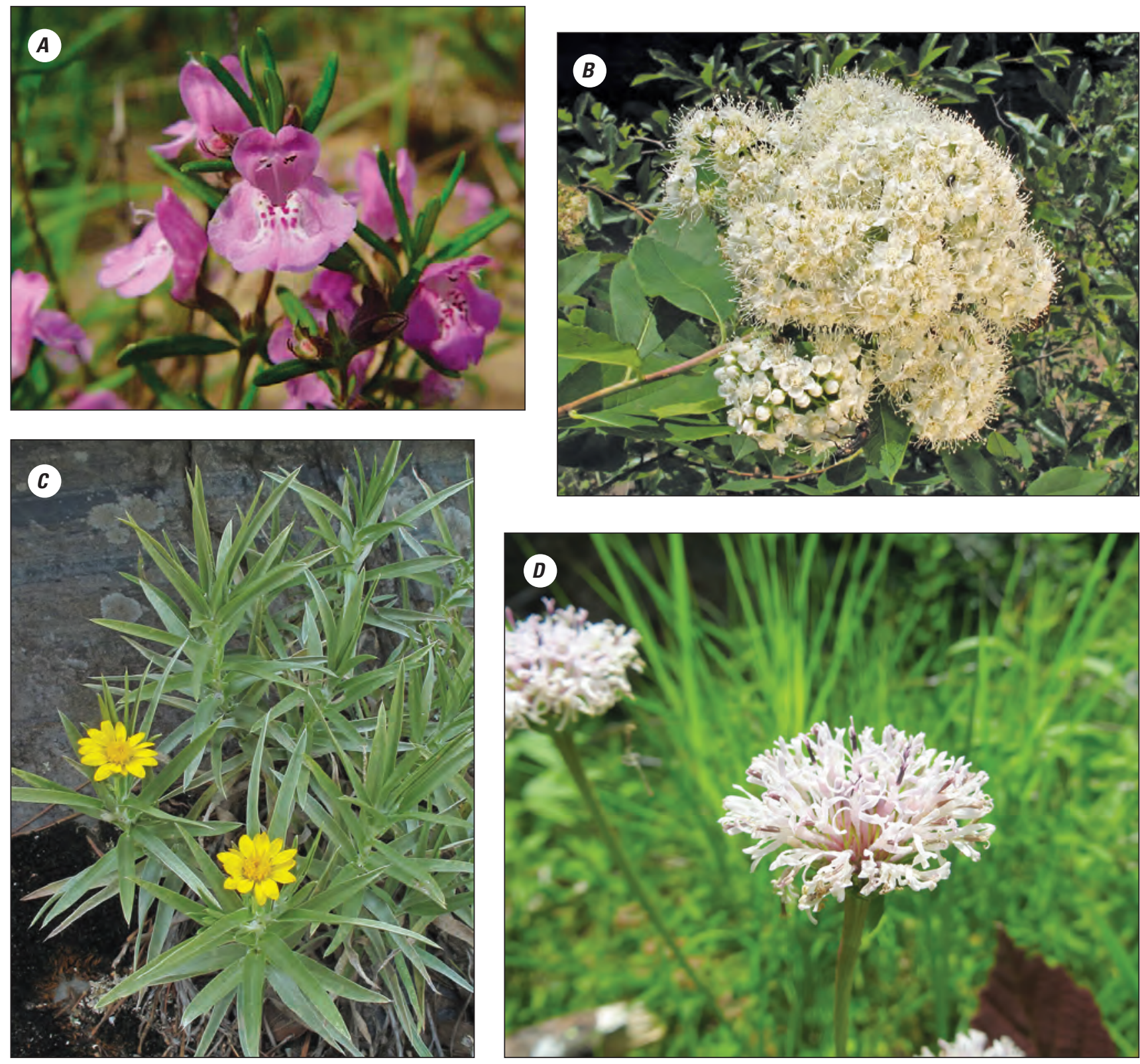

Figure I-5. Rare taxa associated with riverscour habitat in the southeastern United States: $A$, Conradina verticillata, Big South Fork National River and Recreation Area, Tennessee; B, Spiraea virginiana, Walker County, Georgia; $C$, Pityopsis ruthii, Cherokee National Forest, Polk County, Tennessee; D, Marshallia grandiflora, Daddys Creek, Cumberland County, Tennessee. Photograph $A$ by Nora Murdock, National Park Service; photographs $B$ and $C$ by Alan M. Cressler, U.S. Geological Survey; photograph $D$ by Devin Rodgers, Austin Peay State University. 
Some of the rare vascular plant species supported by riverscour ecosystems are apparently endemic to these systems, meaning that their habitat is restricted to floodscoured riparian contexts. Conradina verticillata (fig. I-5A) is a federally listed threatened species and is considered to be a narrow endemic to riverscour ecosystems on the Cumberland Plateau, with populations consisting of small, geographically isolated, clonally reproducing colonies (Albrecht and Penagos, 2012). C. verticillata belongs to a genus that contains only three other species, all of which are endemic to the Gulf Coast region of Alabama and Florida (Nicholson, 1986). Populations of $C$. verticillata have so far been documented only from nine major streams of the Cumberland Plateau. Characteristic habitat has little canopy coverage, includes crevices with moderately deep, sandy, well-drained soils with low organic matter, and is subjected to periodic flood scouring (U.S. Fish and Wildlife Service, 2011). Scouring not only maintains open habitat for $C$. verticillata but also helps propagate it by spreading dislodged plant sections downstream where they can root and establish new populations (Reed, 2003; Taylor, 2003).

Spiraea virginiana (fig. I-5B) is a federally listed threatened species and is a narrow endemic to riverscour ecosystems of the Appalachian Plateaus and Blue Ridge Physiographic Provinces (Ogle, 1991). S. virginiana is a shrub with a modular growth pattern, capable of sexual reproduction but more often reproducing clonally, that is anchored by a heavy lateral rhizome and a fine, fibrous root mass (Ogle, 1991). Flood scouring is believed to be essential to the survival of $S$. virginiana by eliminating arboreal competition. Although much of the above-ground parts of $S$. virginiana may be destroyed in flood events, the belowground part is typically capable of regenerating a clone after disturbance (Ogle, 1991).

Calamovilfa arcuata is a G2-ranked grass with scattered occurrences from Tennessee to Oklahoma, such as in cobble and gravel bars along the Obed River, Daddys Creek, and the Emory River (Schmalzer, 1989; Wolfe and others, 2007) as well as the Caney Fork, Big South Fork Cumberland, and Clear Fork Rivers (Bailey and Coe, 2001). Solidago arenicola is a G2-ranked species inhabiting sandy alluvium in scourprone riparian areas. This goldenrod was originally described from a single population along the Locust Fork River in Alabama, but depending on taxonomic classification, may also be present along rivers in Tennessee such as the Obed (Floden, 2012).

In some cases, riverscour habitats appear to support taxa that are endemic not only to the ecosystem type but also to particular streams. For example, Pityopsis ruthii (fig. I-5C), a federally listed endangered species, is a shade-intolerant herbaceous perennial known only from occurrences in scoured habitat along the Hiwassee and Ocoee Rivers in Polk County, Tennessee, with a total population of around 10,000 individuals (Major and others, 1999; Thomson and Schwartz, 2006). Solidago plumosa is known from only a single population on scoured mafic bedrock along the Yadkin River in North Carolina, and is related to other rare goldenrods found in riverscour contexts, including Solidago arenicola (Peirson and others, 2012; Schafale, 2012). Eurybia saxicastellii is riverscour-endemic aster that is apparently limited to the Rockcastle River in southeastern Kentucky (Campbell and Medley, 1989), the Big South Fork Cumberland River, and the New River in the Big South Fork drainage in Scott County, Tennessee (Bailey and Coe, 2001; Taylor, 2003). These three species are all ranked G1.

Some taxa, such as Phyllanthopsis phyllanthoides ${ }^{12}$ and Cerastium arvense var. velutinum, which have adapted to conditions in barrens and other disturbance-maintained, nonforested environments, can also occupy riverscour habitats (Weakley, 2012). Certain disturbance-adapted or stress-adapted species might be considered "near-endemics" if they are restricted to riverscour systems and related ecosystems. Ptilimnium nodosum, for example, is a federally listed endangered species occupying riverscour sites including cobble and gravel bars and bedrock outcrops that are seasonally flooded but are above water during low-flow periods (Bartgis, 1997). This short-lived semiaquatic species reproduces sexually and asexually and forms meta-populations as ramets and seeds are dispersed by flowing water to form new populations at downstream sites (Bartgis, 1997; Wells, 2012). Populations have been documented along tributaries to the Potomac River in western Maryland and northeastern West Virginia and in several other sites in Alabama, Georgia, North and South Carolina, Virginia, and Arkansas (Wells, 2012). Two ecotypes of the species are essentially riverscour endemics; however, a third ecotype is found in pond habitat (Marcinko, 2007), such that the species as a taxonomic unit may be considered a near-endemic. Marshallia grandiflora (fig. I-5D) is a G2-ranked forb, generally considered endemic to the Appalachian Mountains and the Cumberland Plateau, with occurrences along rivers such as the Clear Fork (Bailey and Coe, 2001), the Big South Fork Cumberland (Medley and Wofford, 1980), the Obed River and its tributaries (Schmalzer and others, 1985), and along rivers such as the Gauley in the Allegheny Mountains of West Virginia (Byers and others, 2007; Vanderhorst and others, 2010). Although this species is primarily riverscour-associated, its historical range has also included bog occurrences in North Carolina (Franklin and Finnegan, 2006), and thus it may be more appropriately categorized as a near-endemic.

Riverscour communities also support plant taxa that are rare at the state or regional level, even if they are globally secure and are not riverscour endemics. For example, riverscour communities within the New River Gorge National River support populations of Aristida purpurascens var. purpurascens, Carex woodii, Commelina erecta var. angustifolia, Coreopsis pubescens var. robusta, Galactia volubilis, Hypericum virgatum, Melica mutica, and Piptochaetium avenaceum, all of which are State-rare in West Virginia (Vanderhorst and others, 2007).

\footnotetext{
${ }^{12}$ Species name according to the Integrated Taxonomic Information System (2015).
} 
In some cases, regionally rare plants in riverscour communities may be biogeographically disjunct from home ranges in other regions or may represent substantial range expansions. For example, Packera paupercula, disjunct from the species main range in the northern United States and Canada, occupies riverscour habitats of the Daniel Boone National Forest (Taylor, 2003). The Cheat River in West Virginia supports populations of Triantha glutinosa, a northern species reaching the southern end of its range at this site (Byers and others, 2007). Rare and threatened species associated with riverscour communities in the Obed Wild and Scenic River in Tennessee include Helenium brevifolium, Polygonella americana, Leucothoe racemosa, and Sporobolus junceus, which are disjunct from the Coastal Plain (Schmalzer, 1989; Shaw and Wofford, 2003; Wolfe and others, 2007).

\section{Conservation Considerations}

As explained in this section, conservation of riverscour ecosystems necessarily involves assessment and evaluation beyond the immediate vicinity of riverscour habitat occurrence. In particular, anthropogenic threats, conservation strategies, and scientific investigations commonly encompass large portions of watersheds. Because riparian ecosystems are influenced by human and natural dynamics at a range of scales, their conservation commonly requires landscape-level analysis in addition to localized hydrologic assessment.

\section{Threats to Ecosystem Integrity}

Riverscour ecosystems are relatively rare throughout their range in the southeastern United States, primarily because they are confined to geographically small corridors along only relatively large-order streams (Bailey and Coe, 2001). Within the Cumberland Plateau, fewer than 500 acres (about 200 hectares) of riverscour habitats are estimated to be in existence (Murdock and others, 2007; U.S. Fish and Wildlife Service, 2011). Even for riverscour sites on protected public land, an array of threats to ecosystem integrity has been identified.

A primary threat to riverscour ecosystems is hydrologic alteration and the associated effects on sediment dynamics. Construction activities that generate sediment from erosion and infrastructure projects such as upstream impoundments that change sediment transport dynamics have the potential to adversely affect riverscour ecosystems by interfering with natural patterns of substrate accumulation and removal (Meijer, 1976; Ogle, 1992; Wolfe and others, 2007). Because the fundamental integrity of these ecosystems depends on particular flood-scouring disturbance regimes, anthropogenic flow alteration - especially flood control - has the potential to facilitate succession toward large woody species, resulting in displacement of certain rare herbaceous riverscour communities (Westervelt and others, 2006). Impoundments also can interfere with the dispersal of some rare riverscour endemic plant species by blocking the effective downstream transport of seeds and clonal fragments (Ogle, 1992).

Impoundments and resulting changes in flooding regime are believed to have harmed some globally rare riverscour communities, including the Hiwassee/Ocoee River boulder scour community (Major and others, 1999). Individual populations of some rare riverscour-endemic species, including Conradina verticillata and Spiraea virginiana, are believed to have been destroyed by the construction of dams (Nicholson, 1986; Ogle, 1991). Forest succession, resulting from a disruption in the flood-scouring disturbance regime because of dam construction, has been identified as a primary threat to the Eastern Red-cedar-Virginia Pine flatrock woodland community of the New River Gorge National River (Mitchem, 2004; Vanderhorst and others, 2007). Managers have recognized road and trail construction within Daniel Boone National Forest on the Cumberland Plateau of Kentucky as a potential threat to riverscour ecosystems due to the potential for altering flow regimes and sediment transport and deposition dynamics (Taylor, 2003). Erosion-produced sedimentation from development within watersheds has also been identified as a threat to riverscour ecosystems on the Big South Fork Cumberland River and the Obed River (Murdock and others, 2007).

In addition to direct hydrologic alteration from impoundments, land-use changes over entire stream basins have the potential to result in more indirect forms of hydrologic alteration, for example by changing the relative permeability of the land surface. Also, regional water-use activities such as upstream water withdrawals and wastewater releases have the potential to affect flow regimes in ways that could threaten the ecological integrity of riverscour communities (Murdock and others, 2007; Wolfe and others, 2007). Basin-level hydrologic alteration-leading to changes in flood and scouring regimeis suspected to have played a role in observed declines of some populations of C. verticillata; however, neither the degree of alteration nor the link to vegetation dynamics has been conclusively established (U.S. Fish and Wildlife Service, 2011).

Invasive exotic species are also frequently cited as a potential threat to riverscour communities; however, the patterns of invasion and the particular species responsible appear to vary based on geographic region and riverscour community type. The Eastern Red-cedar-Virginia Pine flatrock woodland community of the New River Gorge National River is currently threatened with encroachment by exotic species including Lonicera japonica and Rosa multiflora (Mitchem, 2004; Vanderhorst and others, 2007). At two sites within the New River Gorge National River (Camp Brookside and Keeneys Creek), the exotics Sedum sarmentosum, Lespedeza cuneata, and L. bicolor have formed well-established colonies capable of trapping sediment and thus altering the successional dynamics of the ecosystem (Vanderhorst and others, 2007). Riverscour woodland communities can be threatened by the invasive species Lythrum salicaria, Polygonum cuspidatum, and Sorghum halepense, which disperse widely and can 
become established in high-energy riparian corridors (Belden and others, 2003; Westervelt and others, 2006). Invasive species in twisted-sedge rocky creekbed communities include Microstegium vimineum and Polygonum caespitosum var. longisetum (Vanderhorst and others, 2007). Riverscour prairie communities are threatened by the exotics Sorghum halepense, Centaurea biebersteinii, and Lythrum salicaria (Westervelt and others, 2006; Vanderhorst and others, 2007). Within the Big South Fork National River and Recreation Area, Ailanthus altissima, Albizia julibrissin, Spiraea japonica, Ligustrum sinense, Polygonum cuspidatum, Lythrum salicaria, Alliaria petiolata, and Microstegium vimineum have been identified as problematic invasive species in riparian habitats and have been targeted for control by the National Park Service (U.S. Fish and Wildlife Service, 2011). Invasive species in the Obed Wild and Scenic River in Tennessee include Lespedeza cuneata, Elaeagnus umbellata, Albizia julibrissin, Coronilla varia, and Rosa multiflora (Wolfe and others, 2007).

In some cases, invasive exotic species have been named as threats to individual riverscour-adapted species. For example, competition from the exotic species Rosa multiflora, Spiraea japonica, and Polygonum cuspidatum has been implicated in limiting population sizes of the rare riverscour-endemic Spiraea virginiana (Ogle, 1991). Woody encroachment (by both native and exotic species) into riverscour habitat is also believed to be a threat to the rare endemic Conradina verticillata on the Cumberland Plateau (U.S. Fish and Wildlife Service, 2011).

Riverscour communities are also commonly threatened by direct mechanical destruction related to recreational activities such as fishing, hiking, camping, horseback riding, and boating. Sites on publicly protected land are not immune from damage, and such problems have been identified within the New River Gorge National River, the Gauley River National Recreation Area, the Big South Fork National River and Recreation Area, and the Obed Wild and Scenic River (Vanderhorst and others, 2007; U.S. Fish and Wildlife Service, 2011). Trampling is a substantial problem in some riverscour habitats such as cobble bars because the dry, open nature of these sites makes them attractive locations for canoeists looking to rest or camp (Nicholson, 1986).

Because riverscour communities maintain such close contact with regional surface water, contamination may also be a threat in some areas. Urban runoff and sewage releases discharged into rivers, for example, often contain elevated levels of nutrients and contaminants (Wolfe and others, 2007). Water contamination can also result from mining activities within watersheds, especially acidic drainage and siltation from coal mines (Meijer, 1976; Murdock and others, 2007).

\section{Conservation Strategies}

Riverscour ecosystems currently exist on a number of sites on protected public land (table I-2). In recognition of the ecological importance of riverscour ecosystems and the suite of potential threats facing them, a number of agencies have undertaken conservation and management efforts. The Appalachian Highlands Network, an inventory and monitoring network of the National Park Service, has been actively monitoring riverscour habitats and mapping populations of rare or endemic plants within the Big South Fork National River and Recreation Area (fig. I-6) and the Obed Wild and Scenic River since 2005 (Murdock and others, 2007; U.S. Fish and Wildlife Service, 2011) and along the New River since 2013.

\section{Knowledge Gaps}

Although many important contributions have been made toward an understanding of riverscour ecosystems, they are still relatively poorly studied and several key knowledge gaps exist. For example, although it is generally understood that riverscour endemic species require specific disturbance regimes, the tolerance thresholds of flood scouring (intensity, frequency) are generally not known. Research opportunities exist to compare streamflow data with population demographic data for these endemic species to investigate the effects of changing disturbance regimes on species distribution (Ogle, 1992). Also, relatively few studies have been published on the fauna associated with riverscour vegetation. Hutchens and others (2009) found that in the Little Tennessee River in North Carolina, mats of Podostemum ceratophyllum provided important faunal habitat because they were associated with high abundance and biomass of benthic macroinvertebrates. A bee species, Anthidiellum notatum, previously unknown from Virginia, was discovered in a riverside outcrop prairie adjacent to the Potomac River in 2006, prompting the suggestion that "other rare bees might inhabit this globally rare plant community type" (Steury and others, 2009). More information on the fauna associated with other riverscour-adapted species could be helpful to elucidate larger ecosystem dynamics, such as trophic interactions and water-quality influences, in which these species may play important roles.

\section{Possible Ecological Effects from Climate Change}

Explicit discussions of climate change and its possible effects on riverscour ecosystems are limited in the literature. Even when climate change has been mentioned as a potential threat to these ecosystems, statements have typically included little elaboration or presentation of empirical evidence (for example, Byers and others, 2007). Rare plant species associated with riverscour habitat have been mentioned in association with several studies seeking to assess climatechange vulnerability for species of conservation concern at the state level. In West Virginia, for example, Byers and Norris (2011) assessed the climate-change vulnerability of Ptilimnium nodosum to be high and that of Spiraea virginiana and Marshallia grandiflora to be moderate. In Alabama, Davenport (2007) suggested that P. nodosum "will need to shift with shifting climates and water sources" and "will be adversely affected if drier conditions prevail." 
Table I-2. Selected occurrences of riverscour ecosystems on protected public land.

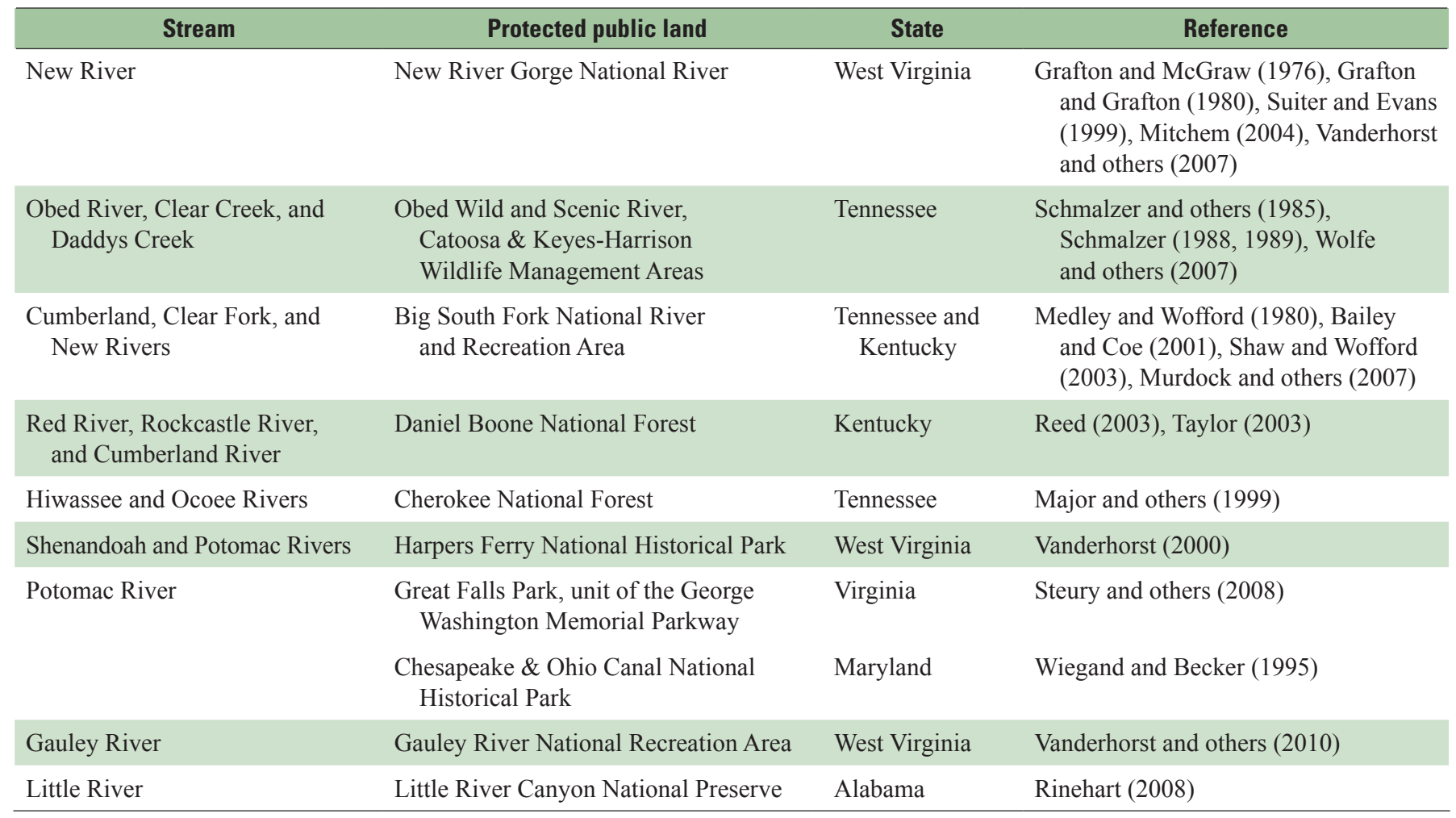

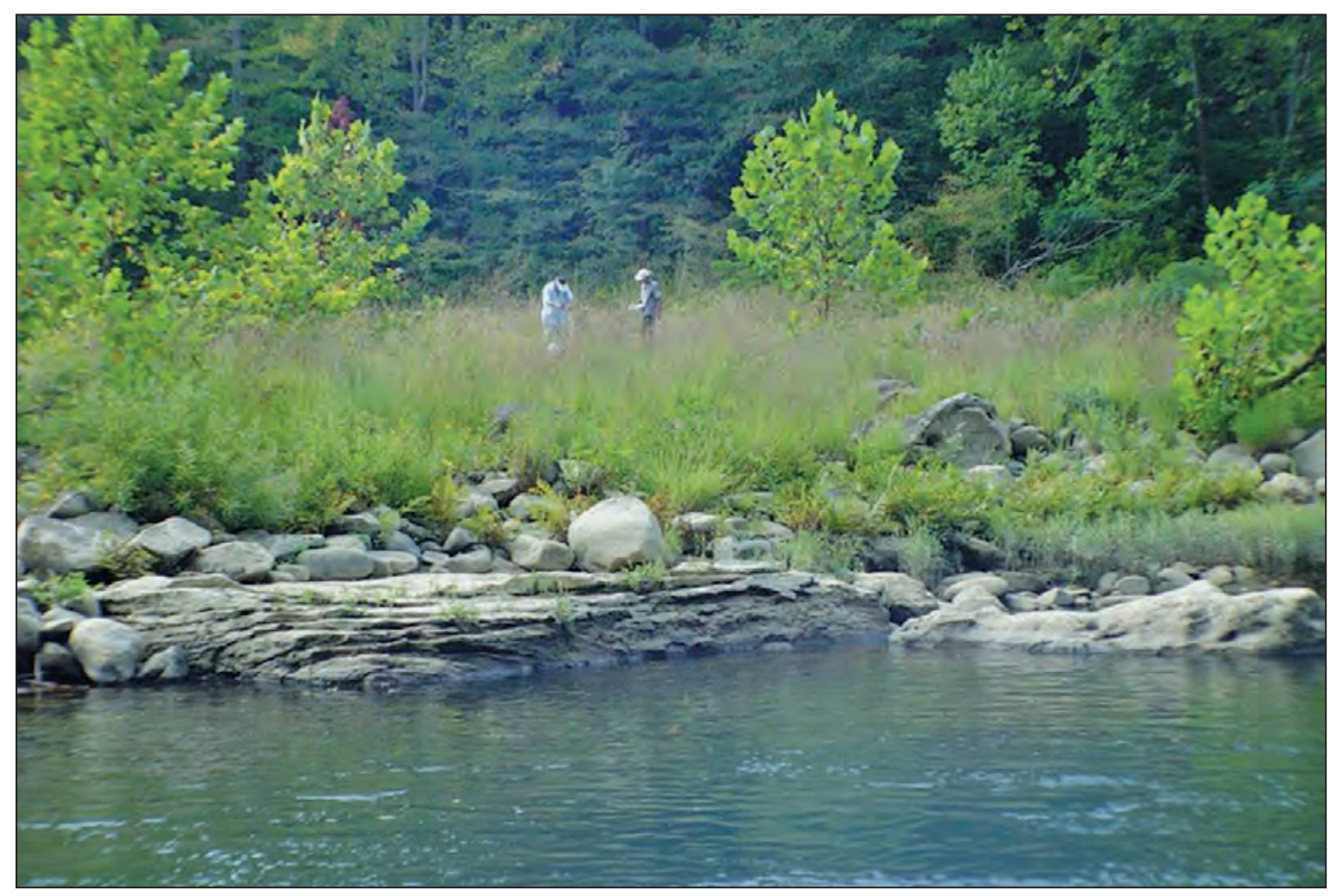

Figure I-6. Habitat monitoring at Leatherwood Ford cobble bar, Big South Fork Cumberland River, Big South Fork National River and Recreation Area, Tennessee. Photograph by Nora Murdock, National Park Service. 
These predictions, however, were made at the level of individual species rather than of plant assemblages or whole communities. Furthermore, these predictions did not include any detailed discussion of the mechanisms by which climate change would affect these species nor did they present new empirical evidence linking species population demographics to changes in habitat indicators.

In the absence of ecosystem-level empirical research concerning climate-change effects on riverscour communities, knowledge of the factors governing ecosystem integrity may be useful to generate hypotheses. Because riverscour ecosystems are largely maintained by flood-scour disturbance regimes, flow-regime alteration could be a key pathway by which changes in regional precipitation patterns might affect riverscour systems. Climate-change effects might be highly variable, however, from stream to stream and even among various riverscour habitats along the same stream. In many cases, natural flow regimes have already been substantially altered by upstream impoundments and by municipal water withdrawals and wastewater releases (Nicholson, 1986; Ogle, 1991; Major and others, 1999; Murdock and others, 2007), such that it is unclear whether or how climate change might further affect flow regimes. Even for streams with relatively few direct forms of hydrologic alteration, any flow-regime changes resulting from shifts in regional precipitation patterns would likely have complex interactive effects with other sources of hydrologic alteration such as watershed-scale land-use change.

Theoretically, if climate change altered the flood-scour disturbance regime such that scour events become less frequent and (or) less intense, then the effects on scourmaintained communities might include woody encroachment by upland species, mirroring the effects produced by flood control from upstream impoundments. Conversely, an alteration of the scouring regime such that scour events become more frequent or more intense might elevate levels of stress beyond the tolerance thresholds of even riverscour-adapted endemic species. Even if the timing and intensity of flood scouring is not affected by climate change, alteration of low-flow conditions might moderate existing stress regimes in riverscour habitat. Seasonally xeric conditions, for example, are an important stress regime component for certain riverscour community types. An increase in summer base flow could theoretically expose such sites to invasion by drought-intolerant competitor species from surrounding upland forests (Wolfe and others, 2007). Additionally, because exotic species invasions can be substantially influenced by climate-change effects (Hellmann and others, 2008), regional changes in temperature or precipitation patterns could theoretically facilitate or exacerbate the expansion of exotic species into riverscour habitats. Evaluation of the likelihood of such scenarios would require research focused on linkages between changing climate conditions, flow regimes, population demographics of scour-adapted taxa, and ecological processes such as succession.

\section{References}

Albrecht, M., and Penagos, J., 2012, Seed germination ecology of three imperiled plants of rock outcrops in the southeastern United States: The Journal of the Torrey Botanical Society, v. 139, no. 1, p. 86-95.

Bailey, C., and Coe, F., 2001, The vascular flora of the riparian zones of the Clear Fork River and the New River in the Big South Fork National River and Recreation Area (BSFNRRA): Castanea, v. 66, no. 3, p. 252-274.

Bartgis, R., 1997, The distribution of the endangered plant Ptilimnium nodosum (Rose) Mathias (Apiaceae) in the Potomac River drainage: Castanea, v. 62, no. 1, p. 55-59.

Belden, A., Chazal, A., and Hobson, C., 2003, A natural heritage inventory of fourteen headwater sites in the Dragon Run Watershed: Richmond, Va., Virginia Department of Conservation and Recreation.

Byers, E., and Norris, S., 2011, Climate change vulnerability assessment of species of concern in West Virginia: Elkins, W. Va., West Virginia Divison of Natural Resources, 69 p.

Byers, E., Vanderhorst, J., and Streets, B., 2007, Classification and conservation assessment of high elevation wetland communities in the Allegheny Mountains of West Virginia: Elkins, W. Va., West Virginia Natural Heritage Program.

Campbell, J., and Medley, M., 1989, Aster saxicastellii (Asteraceae), a new species from the Rockcastle River bars in southeastern Kentucky: Sida, v. 13, no. 3, p. 277-284.

Davenport, L., 2007, Climate change and its potential effects on Alabama's plant life: Birmingham, Ala., Samford University, Vulcan Materials Center for Environmental Stewardship and Education.

Fenneman, N., and Johnson, D., 1946, Physical divisions of the United States: U.S. Geological Survey map prepared in cooperation with the Physiographic Commission, scale 1:7,000,000.

Fleming, G., and Patterson, K., 2012, Natural communities of Virginia-Ecological groups and community types: Richmond, Va., Virginia Department of Conservation and Recreation, Division of Natural Heritage, 36 p.

Floden, A., 2012, Notes on two rare Solidago (Asteraceae) in Tennessee-S. Arenicola and S. simplex: Phytoneuron, v. 63, p. $1-4$.

Franklin, M.A., and Finnegan, J.T., 2006, Natural Heritage Program list of rare plant species of North Carolina 2006: Raleigh, N.C., North Carolina Natural Heritage Program, Office of Conservation and Community. 
Franklin, S., Faber-Langendoen, D., Jennings, M., Keeler-Wolf, T., Loucks, O., Peet, R., Roberts, D., and McKerrow, A., 2012, Building the United States National Vegetation Classification: Annali di Botanica, v. 2, p. 1-9.

Grafton, W., and Grafton, E., 1980, Literature review of geology/soils, plants and animal information pertinent to the New River Gorge National River, West Virginia, unpublished report submitted to staff at the New River Gorge National River.

Grafton, W., and McGraw, C., 1976, The vascular flora of New River Gorge, West Virginia: Beckley, West Virginia, Center for Extension and Continuing Education, West Virginia University, $19 \mathrm{p}$.

Grund, S., and Zimmerman, E., 2009, Youghiogheny River scour-An unusual place for unlikely plants: Keystone WILD! Notes, Pennsylvania Department of Conservation and Natural Resources, p. 15-17.

Hellmann, J.J., Byers, J.E., Bierwagen, B.G., and Dukes, J.S., 2008, Five potential consequences of climate change for invasive species: Conservation Biology, v. 22, no. 3, p. 534-543.

Hupp, C., 1983, Vegetation pattern on channel features in the Passage Creek Gorge, Virginia: Castanea, v. 48, no. 2, p. $62-72$.

Huston, M., 1979, A general hypothesis of species diversity: American Naturalist, v. 113, no. 1, p. 81-101.

Hutchens, J., Wallace, J., and Romaniszyn, E., 2009, Role of Podostemum ceratophyllum Michx. in structuring benthic macroinvertebrate assemblages in a southern Appalachian river: Journal of the North American Benthological Society, v. 23 , no. 4 , p. $713-727$.

Integrated Taxonomic Information System, 2015, The Integrated Taxonomic Information System, accessed October 5, 2015, at http://www.itis.gov.

Jennings, M., Faber-Langendoen, D., Loucks, O., Peet, R., and Roberts, D., 2009, Standards for associations and alliances of the U.S. National Vegetation Classification: Ecological Monographs, v. 79, no. 2, p. 173-199.

Lea, C., 2000, Plant communities of the Potomac Gorge and their relationship to fluvial factors: Fairfax, Virginia, George Mason University, Masters Thesis, 219 p.

Major, C., Bailey, C., Donaldson, J., McCoy, R., Nordman, C., Williams, M., and Withers, D., 1999, An ecological inventory of selected sites in the Cherokee National Forest: Tennessee Department of Environment and Conservation, Tennessee Division of Natural Heritage.
Marcinko, S., 2007, Pattern and process in rare plant conservation-An assessment of the southeastern U.S.: Chapel Hill, North Carolina, University of North Carolina, Masters Thesis, $88 \mathrm{p}$.

Medley, M., and Wofford, B., 1980, Thuja occidentalis L. and other noteworthy collections from the Big South Fork of the Cumberland River in McCreary County, Kentucky: Castanea, v. 45, no. 3, p. 213-215.

Meijer, W., 1976, A note on Podostemum ceratophyllum Michx., as an indicator of clean streams in and around the Appalachian Mountains: Castanea, v. 41, no. 4, p. 319-324.

Mitchem, D., 2004, Characterization of the vegetation and soil of the forest communities at Camp Brookside in Summers County, West Virginia: Blacksburg, Va., Virginia Polytechnic Institute, Masters Thesis, $51 \mathrm{p}$.

Mouw, J., 2009, Influences of flooding and hyporheic exchange on floodplain plant richness and productivity: River Research and Applications, v. 25, p. 929-945.

Murdock, N., Hughes, J., and Emmott, R., 2007, Understanding hydrologic links between "river prairies" and other threatened riparian resources of the Cumberland Plateau, in Selleck, J., ed., Natural resource year in review-2006: Denver, Colo., National Park Service, Natural Resource Program Center, publication D-1859, p. 45-46.

Naiman, R., Decamps, H., and Pollock, M., 1993, The role of riparian corridors in maintaining regional biodiversity: Ecological Applications, v. 3, no. 2, p. 209-212.

Nicholson, R., 1986, To the arks with rabbitbane-Plant conservation at the Arnold Arboretum: Arnoldia, v. 46, no. 3, p. 23-25.

Ogle, D., 1991, Spiraea virginiana Britton-II. Ecology and species biology: Castanea, v. 56, no. 4, p. 297-303.

Ogle, D., 1992, Virginia spiraea (Spiraea virginiana Britton) recovery plan: Newton Corner, Mass., U.S. Fish and Wildlife Service, $39 \mathrm{p}$.

Peirson, J., Reznicek, A., and Semple, J., 2012, Polyploidy, infraspecific cytotype variation, and speciation in goldenrods - The cytogeography of Solidago subsect. Humiles (Asteraceae) in North America: Taxon, v. 61, no. 1, p. 197-210.

Pyne, M., and Withers, D., 1996, Terrestrial and subterranean natural heritage survey of TVA Columbia Project lands: Tennessee Department of Conservation, Division of Natural Heritage, Report No. 96-001.

Reed, T., 2003, Viability assessment report for general forest habitat association, Daniel Boone National Forest, unpublished report submitted to the National Forest Service, U.S. Department of Agriculture, 24 . 
Rinehart, N., 2008, Watershed condition assessment for Little River Canyon National Preserve, Alabama: Bowling Green, Kentucky, Western Kentucky University, Masters Thesis, $166 \mathrm{p}$.

Rood, S.B., Goater, L., Mahoney, J.M., Pearce, C.M., and Smith, D.G., 2007, Floods, fire, and ice-Disturbance ecology of riparian cottonwoods: Canadian Journal of Botany, v. 85, no. 11, p. 1019-1032.

Schafale, M., 2012, Guide to the natural communities of North Carolina, fourth approximation: Raleigh, N.C., North Carolina Natural Heritage Program, 208 p.

Schmalzer, P., 1988, Vegetation of the Obed River Gorge System, Cumberland Plateau, Tennessee: Castanea, v. 53, no. 1, p. 1-32.

Schmalzer, P., 1989, Vegetation and flora of the Obed River gorge system, Cumberland Plateau, Tennessee: Journal of the Tennessee Academy of Science, v. 64, no. 3, p. 161-168.

Schmalzer, P., Patrick, T., and DeSelm, H., 1985, Vascular flora of the Obed Wild and Scenic River, Tennessee: Castanea, v. 50, no. 2, p. 71-88.

Shaw, J., and Wofford, B., 2003, Woody plants of Big South Fork National River and Recreation Area, Tennessee and Kentucky and floristic comparison of selected Southern Appalachian woody: Castanea, v. 68, no. 2, p. 119-134.

Steury, B., Droege, S., and Oberg, E., 2009, Bees (Hymenoptera: Anthophila) of a riverside outcrop prairie in Fairfax County, Virginia: Banisteria, v. 34, p. 17-24.

Steury, B., Fleming, G., and Strong, M., 2008, An emendation of the vascular flora of Great Falls Park, Fairfax County, Virginia: Castanea, v. 73, no. 2, p. 123-149.

Suiter, D., and Evans, D., 1999, Vascular flora and rare species of New River Gorge National River, West Virginia: Castanea, v. 64, no. 1, p. 23-49.

Taylor, D., 2003, Viability assessment report for riparian habitat association, Daniel Boone National Forest, unpublished report submitted to the National Forest Service, U.S. Department of Agriculture, $19 \mathrm{p}$.

Thomson, D.M., and Schwartz, M.W., 2006, Using population count data to assess the effects of changing river flow on an endangered riparian plant: Conservation Biology, v. 20, no. 4, p. 1132-1142.
U.S. Fish and Wildlife Service, 2011, Cumberland rosemary (Conradina verticillata) 5-year review-Summary and evaluation: Cookeville, Tenn., U.S. Fish and Wildlife Service, $14 \mathrm{p}$.

Vanderhorst, J., 2000, Plant communities of Harper's Ferry National Historical Park-Analysis, characterization, and mapping: Elkins, W. Va., West Virginia Division of Natural Resources, West Virginia Natural Heritage Program, 30 p.

Vanderhorst, J.P., Jeuck, J., and Gawler, S.C., 2007, Vegetation classification and mapping of New River Gorge National River, West Virginia: Philadelphia, Pa., U.S. National Park Service, technical report NPS/NER/NRTR_-2007/092, $396 \mathrm{p}$.

Vanderhorst, J., Streets, B., Arcaro, Z., and Gawler, S., 2010, Vegetation classification and mapping of Gauley River National Recreation Area, West Virginia,: Philadelphia, Pa., U.S. National Park Service, technical report NPS/NER/ NRTR—2010/148, 288 p.

Weakley, A., 2012, Flora of the southern and mid-Atlantic States: Chapel Hill, N.C., University of North Carolina Herbarium, 377 p.

Wells, E.F., 2012, Seed germination and reproductive strategies in federally endangered Harperella (Harperella nodosum Rose, Apiaceae): Castanea, v. 77, no. 3, p. 218-223.

Westervelt, K., Largay, E., Coxe, R., McAvoy, W., Perles, S., Podniesinski, G., Sneddon, L., and Walz, K., 2006, A guide to the natural communities of the Delaware Estuary, Version I: Arlington, Va., NatureServe, 371 p.

Wiegand, R., and Becker, P., 1995, Rare plant survey along the C\&O Canal National Historical Park and Potomac River: Maryland Department of Natural Resources, Annapolis, Maryland.

Wolfe, W.J., Fitch, K.C., and Ladd, D.E., 2007, Alluvial bars of the Obed Wild and Scenic River, Tennessee: U.S. Geological Survey Scientific Investigations Map 2007-2972, 6 p.

Zimmerman, E., 2011, Floodplain scour community factsheet, terrestrial and palustrine plant communities of Pennsylvania, Pennsylvania Natural Heritage Program, accessed November 14, 2015, at http://www.naturalheritage. state.pa.us/Community.aspx?=16011. 


\section{Chapter J. Conclusions and Implications}

Each of the ecosystems reviewed in the preceding chapters exists as an "archipelago" of spatially discrete habitat occurrences (islands) embedded within a matrix of contrasting ecosystems. Although these outcrops, grasslands, wetlands, and riparian zones are diverse in their geography, geomorphology, physical environments, and ecological processes, several unifying themes are common to all of them:

1. The contributions of these ecosystems to regional and global biodiversity - in terms of rare, endemic, and biogeographically disjunct plant and animal taxa - are substantial and likely disproportionate to their limited geographic areas;

2. Complex interactions of abiotic stress and disturbance factors help maintain ecological integrity in these ecosystems, with community composition commonly reflecting the interactive effects of multiple forms of stress and disturbance;

3. Each of these ecosystems has a history of anthropogenic damage, with common threats including land-use change, hydrologic alteration, invasive exotic species, and human disruption of historical disturbance regimes;

4. Despite decades of botanical and ecological research on these ecosystems, fundamental knowledge gaps persist concerning key determinants of ecosystem function; and in particular
5. Climate-change effects have been poorly studied in these ecosystems, and empirically derived predictions of climate-change effects are exceedingly rare.

These conclusions have a number of implications for nature conservation in the southeastern United States and beyond. A primary implication is that preservation of the rare habitats provided by insular ecosystems is an important component of regional and global biodiversity conservation. The concentrations of rare, endemic, and disjunct taxa in insular ecosystems arguably qualify them as "biodiversity hotspots" (Myers and others, 2000) at a regional scale. Indeed, recent discoveries of new plants and animals - for example by DeBiase and Taylor (1997), Rogers and others (2004), Kral and Moffett (2009), and Hill (2010) - suggest that the full complement of biodiversity has yet to be described in these ecosystems. Furthermore, it should be noted that the total biodiversity supported by insular ecosystems is considerably greater than the limited subset described in this report. Within the southeastern United States, a number of additional insular ecosystems (ecosystems meeting the definitional criteria itemized in chapter A) are also noteworthy for their strong contributions to regional and global biodiversity (table $\mathrm{J}-1$ ). Similar to the ecosystems discussed in the chapters of this report, these islands of distinct habitat tend to support rare, endemic, and disjunct plant taxa. Also common to these ecosystems are general trends of geographic rarity combined with threats from human activities.

Table J-1. Examples of additional insular ecosystems in the southeastern United States.

\begin{tabular}{ll}
\multicolumn{1}{c}{ Ecosystem description } & \multicolumn{1}{c}{ Reference } \\
\hline $\begin{array}{l}\text { Ice ponds at cliff bases in the Blue Ridge of South Carolina } \\
\text { Ephemeral ponds of the Cumberland Plateau }\end{array}$ & Hill (1999) \\
Spray cliffs of the Chattooga Basin & Scheffers and others (2006) \\
Cliffs in river gorges of the Cumberland Plateau & Zartman and Pittillo (1998) \\
Bayhead swamps of interior Louisiana & Nepal (2010), Boggess (2013) \\
Chalk bluffs and outcrops near the Black Prairie region in Mississippi & Smith (1996) \\
Sandstone outcrops on the Cumberland Plateau, in the Atahama Grit region & Morris and others (1993) \\
of Georgia, and along the Fall Line in South Carolina & Quarterman and others (1993) \\
Sandstone rockhouses of the Appalachian and Interior Low Plateaus & Walck and others (1996) \\
Serpentine barrens of the eastern Appalachians and the Piedmont & Tyndall and Hull (1999) \\
Southern Appalachian peat bogs & Steward and Nilsen (1993) \\
Georgia Eocene chalk prairies & Echols and Zomlefer (2010) \\
Cypress domes of peninsular Florida & Kurz and Wagner (1953) \\
Sandhill vegetation patches of peninsular Florida & Laessle (1958) \\
\hline
\end{tabular}


Of course, insular ecosystems are by no means limited to the southeastern United States and in fact are probably a global phenomenon (table J-2). Across several continents, insular ecosystems (of which the examples presented here are illustrative but by no means fully representative) provide important contributions to regional and global biodiversity and are generally under threat from anthropogenic forces.

A second implication of these conclusions is that no single management approach is likely to be sufficient for conserving biodiversity across all insular ecosystems. As described in previous chapters, many ecosystems have been subjected to such degrees of qualitative degradation and quantitative destruction that they can be conceived of as "endangered ecosystems," a term applied by Noss and others (1995) to several insular ecosystems including limestone cedar glades, pocosins, Carolina (Delmarva) bays, Appalachian bogs, and upland wetlands of the Tennessee Highland Rim. Some anthropogenic threats, such as development and conversion to agriculture, may be effectively mitigated by traditional conservation approaches, such as public land ownership and habitat conservation plans for rare taxa. Mitigating threats from larger-scale processes, such as regional hydrologic alteration, invasive species, and contamination of air and water, will likely require additional conservation measures and the coordination of diverse groups of stakeholders. Because many ecosystem occurrences have been severely degraded but not destroyed, restoration efforts offer some promise for expanding and improving habitat for rare taxa (Vandevender, 2006; Duncan and others, 2008; De Steven and others, 2010). As was discussed for several ecosystems in previous chapters, these restoration efforts commonly require holistic assessment of landscape-scale as well as site-specific environmental conditions and ecological processes (Pavlovic, 1994; Bruland and others, 2003; VanZandt and others, 2005; Vepraskas and others, 2007). In cases where suitable but unoccupied habitat exists for rare taxa, management options may include reintroduction efforts to establish new populations (Johnson, 1996; Kutner and Morse, 1996; Morse, 1996; Wiser and others, 1998; Nordman, 2004; Albrecht and McCue, 2010).
A third and related implication is that best management practices for insular ecosystems may differ from those for geographically continuous and widespread ecosystems. By definition, insular ecosystems provide naturally fragmented habitat to their constituent organisms. As a result, some taxa of conservation concern may be subject to the commonly observed effects of small and isolated populations, including barriers to gene flow, reduced population genetic diversity, and increased vulnerability to localized extinctions (Godt and others, 1996). Where these factors are at work, effective protection of biodiversity in insular ecosystems (metaphorical archipelagos) may require the preservation of discrete habitat occurrences (islands) ranging across the full spectrum of areal size, geographic range, and environmental conditions. The need to preserve habitat diversity within any given category of insular ecosystem - rather than simply conserving a few large "representative" examples - stems from two primary observations. First, evidence suggests that communities in small islands are not simply representative subsets of those in larger islands because of differences in ecologically relevant environmental conditions that are associated with island size (Snodgrass and others, 2000; Sharitz, 2003). Indeed, small islands such as "dry-end wetlands" in geographically isolated upland depressions likely serve essential ecological functions that are not redundant to their larger counterparts (Whigham, 1999). Second, small islands may be essential as "stepping stones" to facilitate gene flow between larger islands, especially for plant taxa incapable of long-distance dispersal (Mann and others, 1999; Leibowitz, 2003; Tiner, 2003; Cofer and others, 2008). Thus, effective management of insular ecosystems may necessitate "portfolio diversification" in terms of the individual habitat occurrences that are targeted for protection.

All of the conclusions above highlight the need for ongoing ecological research in insular ecosystems. Investigations of the factors and processes that regulate biodiversity in these ecosystems - including stress and disturbance regimes, successional dynamics, relationships across trophic levels, and human influences - have the potential to contribute substantially toward the emerging field of conservation biogeography

Table J-2. Examples of insular ecosystems outside the southeastern United States.

\begin{tabular}{ll}
\multicolumn{1}{c}{ Ecosystem description } & \multicolumn{1}{c}{ Reference } \\
\hline Athabasca sand dunes in Saskatchewan, Canada & Purdy and others (1994), (Hill, 1999) \\
Ironstone outcrops in Brazil & Jacobi and others (2007) \\
Rupestrian fields in Brazil & Ribeiro and Fernandes (2000) \\
Chalk barrens and riparian canyons in the Pikes Peak region of Colorado, USA & Kelso and others (2001) \\
Serpentine barrens in California, USA & Harrison and others (2006) \\
Calcareous alvars in several European regions & Pärtel and others (2001) \\
$\begin{array}{l}\text { Vernal pools occurring globally in regions with Mediterranean climate } \\
\text { Granitic and gneissic inselbergs in several African countries, in Brazil, and in } \\
\quad \text { western Australia }\end{array}$ & Keeley and Zedler (1998), Zedler (2003) \\
Quartzite and dolomite outcrops and grasslands in the Transvaal Escarpment, & Matthews and others (1993) \\
South Africa &
\end{tabular}


(Whittaker and others, 2005; Ladle and Whittaker, 2011). Likewise, a fusion of investigative approaches from the fields of biogeography and conservation biology may help elucidate the determinants of community structure within islands and of distribution patterns for rare taxa across archipelagos. Identification of these determinants and improved understanding of their dynamic interactions may prove critical to conserving insular ecosystems as regional climatic conditions change.

Profound and well-documented ecological effects of climate change at a global level (Parmesan and Yohe, 2003; Parmesan, 2006; Walther, 2010) suggest that more vigorous and focused efforts are needed to anticipate such changes in insular ecosystems and to recognize them as they occur. In particular, hypothesis-driven studies are needed that mechanistically link long-term demographic trends of sensitive populations to changing environmental conditions; for example, see McCarthy and Evans (2000) and Wolfe and others (2004). Also important are efforts to discern and interpret differences in community structure along climatic gradients; for example, see Wiser (1998). For some ecosystems, the stress and disturbance factors described in the previous chapters may represent reasonable starting points for hypothesis generation and testing. For example, community structure is strongly linked to hydrologic conditions in a variety of insular ecosystems such as depression wetlands and rock outcrops. Soil surface temperatures and (or) temperature-dependent evapotranspiration dynamics are important in some cases, as are weather-related disturbances such as storms, fires, and droughts. All of these factors - as well as their interactive effects - may be affected by climate change over the coming decades (Easterling and Evans, 2000; Hanson and Weltzin, 2000; Trenberth and others, 2013; Mitchell and others, 2014).

The process of linking changing climatic conditions to ecological outcomes will necessarily be complex and subject to multiple sources of uncertainty. A fundamental source of uncertainty concerns the magnitude, velocity, and nature of regional climate change (Chen and others, 2003; Monier and others, 2014). Uncertainty is compounded at each of several additional levels of analysis and interpretation that are required for prediction of ecological outcomes. Changes in regional climate may produce shifts in localized microclimatic conditions that vary across microhabitats (Kutner and Morse, 1996; Ashcroft, 2010; Storlie and others, 2014). Interactive effects between multiple types of abiotic change (for example, increased soil surface temperature combined with increased drought frequency) may shift localized stress regimes in ways that could not be predicted by examining each abiotic change independently. Based on idiosyncratic stress-tolerance capacities, different plant taxa may respond differently to changing stress regimes (Ahmad and Prasad, 2011; Panda and others, 2013), with consequences for interspecific interactions that may be difficult to predict. At a global level, cases have been documented in which phenophase change occurred at different rates between taxa linked by mutualistic relationships such as pollination, leading to a breakdown of interspecific interactions known as phenological mismatch (Parmesan, 2006; Fabina and others, 2010; Walther, 2010; Thackeray and others, 2010). Evaluating the potential for such situations in insular ecosystems requires detailed knowledge concerning interspecific interactions and the abiotic conditions that regulate them. All of these sources of uncertainty highlight the need for increased scientific investigation of insular ecosystems and the webs of interactions that regulate their ecological function.

\section{References}

Ahmad, P., and Prasad, M., eds., 2011, Environmental adaptations and stress tolerance of plants in the era of climate change: New York, Springer.

Albrecht, M., and McCue, K., 2010, Changes in demographic processes over long time scales reveal the challenge of restoring an endangered plant: Restoration Ecology, v. 18, no. S2, p. 235-243.

Ashcroft, M.B., 2010, Identifying refugia from climate change: Journal of Biogeography, v. 37, p. 1407-1413.

Boggess, L., 2013, Cliff ecology of the Big South Fork National River and Recreation Area: Appalachian State University, Masters Thesis.

Bruland, G., Hanchey, M., and Richardson, C., 2003, Effects of agriculture and wetland restoration on hydrology, soils, and water quality of a Carolina bay complex: Wetlands Ecology and Management, v. 11, p. 141-156.

Chen, M., Pollard, D., and Barron, E., 2003, Comparison of future climate change over North America simulated by two regional models: Journal of Geophysical Research, v. 108, no. D12, p. ACL 3-1-ACL 3-19.

Cofer, M., Walck, J., and Hidayati, S., 2008, Species richness and exotic species invasion in Middle Tennessee cedar glades in relation to abiotic and biotic factors: The Journal of the Torrey Botanical Society, v. 135, no. 4, p. 540-553.

DeBiase, A., and Taylor, B., 1997, Aglaodiaptomus atomicus, a new species (Crustacea: Copepoda: Calanoida: Diaptomidae) from freshwater wetland ponds in South Carolina, USA, and a redescription of $A$. saskatchewanensis (Wilson 1958): Proceedings of the Biological Society of Washington, v. 110, no. 4, p. 569-580.

De Steven, D., Sharitz, R., and Barton, C., 2010, Ecological outcomes and evaluation of success in passively restored southeastern depressional wetlands: Wetlands, v. 30, no. 6, p. $1129-1140$.

Duncan, R., Anderson, C., Sellers, H., and Robbins, E., 2008, The effect of fire reintroduction on endemic and rare plants of a southeastern glade ecosystem: Restoration Ecology, v. 16 , no. 1 , p. 39-49. 
Easterling, D., and Evans, J., 2000, Observed variability and trends in extreme climate events-A brief review: Bulletin of the American Meteorological Society, v. 81, no. 3, p. $417-425$.

Echols, S., and Zomlefer, W., 2010, Vascular plant flora of the remnant blackland prairies in Oaky Woods Wildlife Management Area, Houston County, Georgia: Castanea, v. 75 , no. 1, p. $78-100$.

Fabina, N.S., Abbott, K.C., and Gilman, R.T., 2010, Sensitivity of plant-pollinator-herbivore communities to changes in phenology: Ecological Modelling, v. 221, no. 3 , p. $453-458$.

Godt, M., Johnson, B., and Hamrick, J., 1996, Genetic diversity and population size in four rare southern Appalachian plant species: Conservation Biology, v. 10, no. 3, p. 796-805.

Hanson, P.J., and Weltzin, J.F., 2000, Drought disturbance from climate change-Response of United States forests: The Science of the Total Environment, v. 262, p. 205-220.

Harrison, S., Safford, H., and Grace, J., 2006, Regional and local species richness in an insular environmentSerpentine plants in California: Ecological Monographs, v. 76 , no. 1, p. $41-56$.

Hill, J., 2010, A new species of Melanoplus (Orthoptera: Acrididae: Melanoplinae) from the cedar glades of Tennessee, USA: Journal of Orthoptera Research, v. 19, no. 2 , p. 341-345.

Hill, S., 1999, The relict flora of ice ponds in South Carolina: Castanea, v. 64, no. 1, p. 14-22.

Jacobi, C.M., Carmo, F.F., Vincent, R.C., and Stehmann, J.R., 2007, Plant communities on ironstone outcrops - A diverse and endangered Brazilian ecosystem: Biodiversity and Conservation, v. 16 , no. 7 , p. 2185-2200.

Johnson, B., 1996, Southern Appalachian rare plant reintroductions on granite outcrops, in Faulk, D., Miller, C., and Olwell, M., eds., Restoring diversity-Strategies for reintroduction of endangered plants: Washington, D.C., Island Press, p. 433-444.

Keeley, J., and Zedler, P., 1998, Characterization and global distribution of vernal pools, in Witham, C., Bauder, E., Belk, D., Ferren, W., and Ornduff, R., eds., Ecology, Conservation, and Management of Vernal Pool Ecosystems-Proceedings from a 1996 Conference of the California Native Plant Society, Sacramento, California, p. 1-14.

Kelso, S., Hall, C., and Maentz, G., 2001, The role of landscape anomalies in regional plant conservation, in Southwestern Rare and Endangered Plants, Proceedings of the Third Conference: Flagstaff, Arizona, p. 13-19.
Kral, R., and Moffett, J., 2009, Xyris spathifolia (Xyridaceae), a new xyrid from the Ketona dolomite-limestone glades of Alabama: Journal of the Botanical Research Institute of Texas, v. 3, no. 2, p. 469-478.

Kurz, H., and Wagner, K., 1953, Factors in cypress dome development: Ecology, v. 34, no. 1, p. 157-164.

Kutner, L., and Morse, L., 1996, Reintroduction in a changing climate, in Faulk, D., Miller, C., and Olwell, M., eds., Restoring diversity - Strategies for reintroduction of endangered plants: Washington, D.C., Island Press, p. 23-48.

Ladle, R., and Whittaker, R., eds., 2011, Conservation biogeography: Oxford, United Kingdom, Blackwell, 320 p.

Laessle, A., 1958, The origin and successional relationship of sandhill vegetation and sand-pine scrub: Ecological Monographs, v. 28, no. 4, p. 361-387.

Leibowitz, S., 2003, Isolated wetlands and their functionsAn ecological perspective: Wetlands, v. 23, no. 3, p. $517-531$

Mann, L., King, A., Dale, V., Hargrove, W., Washington-Allen, R., Pounds, L., and Ashwood, T., 1999, The role of soil classification in geographic information system modeling of habitat pattern - Threatened calcareous ecosystems: Ecosystems, v. 2, p. 524-538.

Matthews, W.S., van Wyk, A.E., and Bredenkamp, G.J., 1993, Endemic flora of the north-eastern Transvaal Escarpment, South Africa: Biological Conservation, v. 63 , no. 1, p. 83-94.

McCarthy, S., and Evans, J., 2000, Population dynamics of overcup oak (Quercus lyrata) in a seasonally flooded karst depression: Journal of the Torrey Botanical Society, v. 127, no. 1, p. 9-18.

Mitchell, R.J., Liu, Y., O’Brien, J.J., Elliott, K.J., Starr, G., Miniat, C.F., and Hiers, J.K., 2014, Future climate and fire interactions in the southeastern region of the United States: Forest Ecology and Management, v. 327, p. 316-326.

Monier, E., Gao, X., Scott, J.R., Sokolov, A.P., and Schlosser, C.A., 2014, A framework for modeling uncertainty in regional climate change: Climatic Change, v. 131 , no. 1, p. $51-66$.

Morris, M., Bryson, C., and Warren, R., 1993, Rare vascular plants and associate plant communities from the Sand Creek Chalk Bluffs, Oktibbeha County, Mississippi: Castanea, v. 58 , no. 4 , p. $250-259$.

Morse, L., 1996, Plant rarity and endangerment in North America, in Faulk, D., Miller, C., and Olwell, M., eds., Restoring diversity - Strategies for reintroduction of endangered plants: Washington, D.C., Island Press, p. 7-22. 
Myers, N., Mittermeier, R.A., Mittermeier, C.G., Fonseca, G.A.B., and Kent, J., 2000, Biodiversity hotspots for conservation priorities: Nature, v. 403, p. 853-858.

Nepal, B., 2010, Characterization of the vegetational communities associated with ancient Juniperus virginiana $\mathrm{L}$. stands in the Obed Wild and Scenic River Gorge: Appalachian State University, Masters Thesis.

Nordman, C., 2004, Vascular plant community classification for Stones River National Battlefield: Durham, N.C., NatureServe.

Noss, R., LaRoe, E., and Scott, J., 1995, Endangered ecosystems of the United States-A preliminary assessment of loss and degradation: Washington, D.C., U.S. Department of the Interior.

Panda, B.B., Achary, V.M.M., Mahanty, S., and Panda, K.K., 2013, Plant adaptation to abiotic and genotoxic stressRelevance to climate change and evolution, in Tuteja, N., and Gill, S.S., eds., Climate change and plant abiotic stress tolerance: Weinheim, Germany, Wiley-VCH Verlag GmbH \& Co. KGaA.

Parmesan, C., 2006, Ecological and evolutionary responses to recent climate change: Annual Review of Ecology, Evolution, and Systematics, v. 37, no. 2006, p. 637-669.

Parmesan, C., and Yohe, G., 2003, A globally coherent fingerprint of climate change impacts across natural systems: Nature, v. 421, no. 6918 , p. 37-42.

Pärtel, M., Moora, M., and Zobel, M., 2001, Variation in species richness within and between calcareous (alvar) grassland stands - The role of core and satellite species: Plant Ecology, v. 157, p. 203-211.

Pavlovic, N., 1994, Disturbance-dependent persistence of rare plants-Anthropogenic impacts and restoration implications, in Bowles, M., and Whelan, C., eds., Restoration of endangered species - Conceptual issues, planning and implementation: Melbourne, Australia, Cambridge University Press, p. 159-193.

Porembski, S., and Barthlott, W., 2000, Granitic and gneissic outcrops (inselbergs) as centers of diversity for desiccationtolerant vascular plants: Plant Ecology, v. 151, no. 1, p. 19-28.

Purdy, B., Bayer, R., and Macdonald, S., 1994, Variation, breeding system evolution, and conservation of the narrow sand dune endemic Stellaria arenicola and the widespread S. longipes (Caryophyllaceae): American Journal of Botany, v. 81, no. 7, p. 904-911.
Quarterman, E., Burbanck, M., and Shure, D., 1993, Rock outcrop communities - Limestone, sandstone, and granite, in Martin, W., Boyce, S., and Echternacht, A., eds., Biodiversity of the southeastern United States-Upland terrestrial communities: New York, John Wiley and Sons, Inc., p. 35-86.

Ribeiro, K., and Fernandes, G., 2000, Patterns of abundance of a narrow endemic species in a tropical and infertile montane habitat: Plant Ecology, v. 147, p. 205-218.

Rogers, D., Jensen, J., and Floyd, T., 2004, Eubranchipus stegosus n. sp. (Crustacea: Anostraca), a bizarre new species of fairy shrimp from the southeastern United States: Hydrobiologia, v. 528, p. 201-207.

Scheffers, B.R., Berton, J., Harris, C., and Haskell, D.G., 2006, Avifauna associated with ephemeral ponds on the Cumberland Plateau: Journal of Field Ornithology, v. 77, no. 2 , p. 178-183.

Sharitz, R., 2003, Carolina bay wetlands-Unique habitats of the southeastern United States: Wetlands, v. 23, no. 3, p. 550-562.

Smith, L., 1996, The rare and sensitive natural wetland plant communities of interior Louisiana: Baton Rouge, La., Louisiana Natural Heritage Program, Department of Wildlife and Fisheries, $40 \mathrm{p}$.

Snodgrass, J., Komoroski, M., Bryan, A., and Burger, J., 2000, Relationships among isolated wetland size, hydroperiod, and amphibian species richness - Implications for wetland regulations: Conservation Biology, v. 14, no. 2, p. 414-419.

Steward, C., and Nilsen, E., 1993, Association of edaphic factors and vegetation in several isolated Appalachian peat bogs: Bulletin of the Torrey Botanical Club, v. 120, no. 2, p. $128-135$.

Storlie, C., Merino-Viteri, A., Phillips, B., VanDerWal, J., Welbergen, J., and Williams, S., 2014, Stepping inside the niche-Microclimate data are critical for accurate assessment of species' vulnerability to climate change: Biology Letters, v. 10, no. 9, 4 p.

Thackeray, S.J., Sparks, T.H., Frederiksen, M., Burthe, S., Bacon, P.J., Bell, J.R., Botham, M.S., Brereton, T.M., Bright, P.W., Carvalho, L., Clutton-Brock, T., Dawson, A., Edwards, M., Elliott, J.M., and others, 2010, Trophic level asynchrony in rates of phenological change for marine, freshwater and terrestrial environments: Global Change Biology, v. 16, no. 12, p. 3304-3313.

Tiner, R.W., 2003, Geographically isolated wetlands of the United States: Wetlands, v. 23, no. 3, p. 494-516. 
Trenberth, K.E., Dai, A., van der Schrier, G., Jones, P.D., Barichivich, J., Briffa, K.R., and Sheffield, J., 2013, Global warming and changes in drought: Nature Climate Change, v. 4 , no. 1 , p. 17-22.

Tyndall, R., and Hull, J., 1999, Vegetation, flora, and plant physiological ecology of serpentine barrens of eastern North America, in Anderson, R., Fralish, J., and Baskin, J., eds., Savannas, barrens, and rock outcrop plant communities of North America: New York, Cambridge University Press, p. 67-82.

Vandevender, J., 2006, Native plant restoration at Stones River National Battlefield, in People, Places and Parks, Proceedings of the 2005 George Wright Society Conference on Parks, Protected Areas and Cultural Sites: The George Wright Society, Inc., p. 146-148.

VanZandt, P., Collins, E., Losos, J., and Chase, J., 2005, Implications of food web interactions for restoration of Missouri Ozark glade habitats: Restoration Ecology, v. 13, no. 2, p. 312-317.

Vepraskas, M., White, J., Amoozegar, A., Hesterberg, D., Huffman, R., Skaggs, R., Gregory, J., Broome, S., Caldwell, P., Davis, K., Abit, S., Smith, H., Zelasko, A., and Brownfield, C., 2007, Methodology to assess soil, hydrologic, and site parameters that affect wetland restoration, phase 2: Raleigh, North Carolina, North Carolina State University, 241 p.

Walck, J., Baskin, J., Baskin, C., and Francis, S., 1996, Sandstone rockhouses of the eastern United States, with particular reference to the ecology and evolution of the endemic plant taxa: The Botanical Review, v. 62, no. 4, p. 311-362.
Walther, G., 2010, Community and ecosystem responses to recent climate change: Philosophical Transactions of the Royal Society, v. 365, p. 2019-2024.

Whigham, D., 1999, Ecological issues related to wetland preservation, restoration, creation and assessment: Science of the Total Environment, v. 240, p. 31-40.

Whittaker, R.J., Araújo, M.B., Jepson, P., Ladle, R.J., Watson, J.E.M., and Willis, K.J., 2005, Conservation biogeography-Assessment and prospect: Diversity and Distributions, v. 11, p. 3-24.

Wiser, S., 1998, Comparison of southern Appalachian highelevation outcrop plant communities with their northern Appalachian counterparts: Journal of Biogeography, v. 25, no. 3, p. 501-513.

Wiser, S., Peet, R., and White, P., 1998, Prediction of rareplant occurrence-A southern Appalachian example: Ecological Applications, v. 8, no. 4, p. 909-920.

Wolfe, W.J., Evans, J.P., McCarthy, S., Gain, W.S., and Bryan, B.A., 2004, Tree-regeneration and mortality patterns and hydrologic change in a forested karst wetland-Sinking Pond, Arnold Air Force Base, Tennessee: U.S. Geological Survey Water-Resources Investigations Report 03-4217, 62 p.

Zartman, C., and Pittillo, J., 1998, Spray cliff communities of the Chattooga Basin: Castanea, v. 63, no. 3, p. 217-240.

Zedler, P.H., 2003, Vernal pools and the concept of "isolated wetlands": Wetlands, v. 23, no. 3, p. 597-607. 


\section{Glossary}

Allelopathy The process by which one plant inhibits the growth or germination of another by releasing chemicals into the environment.

Autecology The study of the ecological relationships between an individual species and its environment.

C3 photosynthesis The most common metabolic pathway for carbon fixation by plants, common in mesic environments.

C4 photosynthesis A metabolic pathway for carbon fixation by plants, most commonly found in environments characterized by high insolation, high temperatures, and low moisture availability.

CAM photosynthesis The Crassulacean acid metabolism pathway for carbon fixation by plants, most commonly found in environments characterized by high insolation, high temperatures, and low moisture availability.

Calcareous Characterized by the presence of calcium carbonate derived from sedimentary carbonate rocks such as limestone and dolomite.

Climax The final stage of succession attainable by a plant community based on the environmental conditions in a particular place at a particular time.

Cryptogam A plant that reproduces by spores without flowers or seeds, including ferns and mosses.

Community A group consisting of populations of two or more different species inhabiting the same geographic area at the same time.

Congener An organism belonging to the same taxonomic group as another.

Disjunct An isolated population of plants or animals far from their typical geographic range.

Dispersal The movement of individual organisms or their reproductive structures from one geographic area to another.
Distribution The spatial arrangement of a biological taxon.

Disturbance An event or episodic series of events, such as fires and floods, producing intense environmental stress over a relatively short period of time.

Ecotone A transitional zone between ecological communities with different environmental conditions.

Edaphic Related to soil.

Endemic Primarily restricted to a particular ecosystem.

G1 Conservation status ranking indicating that an association or taxonomic unit is critically imperiled globally and at very high risk of extinction.

G2 Conservation status ranking indicating that an association or taxonomic unit is imperiled globally and at high risk of extinction.

G3 Conservation status ranking indicating that an association or taxonomic unit is vulnerable globally and at moderate risk of extinction.

Geographic range The geographic area occupied by a species, also known as the species range.

Hemicryptophyte A perennial plant with reproductive structures located at the soil surface.

Hydroperiod The amount of time a wetland is covered by or saturated with water.

Hydrophytic Vegetation that thrives in saturated or inundated conditions.

Insular ecosystem An ecosystem characterized by (1) geographic discreteness, (2) narrow geographic distribution tied to geology, elevation, or similar environmental factors, (3) biogeographic endemism or disjunction, (4) high levels of abiotic stress factors, and (5) steep environmental and ecological boundaries. 
Life-form spectra Plant classifications based on position of perennating tissue relative to the ground surface.

Life history The sequence of events related to an organism's survival and reproduction.

Mesic Environmental conditions characterized by moderate amounts of moisture, as well as species adapted to those environmental conditions.

Obligate heliophyte A plant that requires high levels of light and is susceptible to reduced fitness in shaded conditions.

Phenophase An observable phase in the annual life cycle of an organism or species.

Phenology The seasonal cycle of phenophases and their relationships with environmental conditions.

Population A group of individuals of the same species inhabiting the same geographic area at the same time.

Richness The number of distinct species in an ecological community.

S1 Conservation status ranking indicating that an association or taxonomic unit is critically imperiled at the state level.

S2 Conservation status ranking indicating that an association or taxonomic unit is imperiled at the state level.
S3 Conservation status ranking indicating that an association or taxonomic unit is vulnerable at the state level.

Saturation A hydrologic condition whereby soil pore space is completely filled by water.

Seepage The slow discharge of groundwater at the land surface.

Seral stage An intermediate community as an ecosystem progresses toward climax in the process of succession.

Stress regime The patterns of variation and interaction of abiotic stress factors influencing ecological processes such as competition and succession.

Succession The evolution over time of ecosystem structure and composition.

Taxa Taxonomic groups of any rank, such as varieties, sub-species, species, genera, families, or classes.

Therophyte An annual plant that survives unfavorable seasons in the form of seeds only.

Woody encroachment The process by which woody plants such as shrubs and trees colonize areas previously occupied by herbaceous plants.

Xeric Environmental conditions characterized by lack of soil moisture. 


\section{Appendix 1. Ecological System Names According to the International Terrestrial Ecological Systems Classification}

The International Terrestrial Ecological Systems Classification (ITESC) is a system used for the classification and mapping of terrestrial ecosystems (NatureServe, 2003). The ecosystem categories described in the preceding chapters all generally correspond to one or more ecological systems according to the ITESC (table 1-1). In some cases, lists of ITESC systems are not exhaustive because of imperfect correspondence between ITESC system classification and ecosystem conceptualization by previous studies. In some cases, only a certain subset of vegetation communities associated with a particular ITESC system are associated with the ecological system described in this report. Detailed descriptions of ITESC systems are available in NatureServe Explorer (NatureServe, 2015).

Table 1-1. Selected insular ecosystems of the southeastern United States, with selected corresponding ecological system names according to the International Terrestrial Ecological Systems Classification (ITESC).

\begin{tabular}{|c|c|c|}
\hline Ecological system & ITESC ecological system name(s) & ITESC identifier \\
\hline Piedmont granite outcrops & Southern Piedmont Granite Flatrock and Outcrop & CES202.329 \\
\hline Limestone cedar glades & Nashville Basin Limestone Glade and Woodland & CES202.334 \\
\hline \multirow[t]{7}{*}{ Xeric limestone prairies } & Ozark Prairie and Woodland (subset) & CES202.326 \\
\hline & Western Highland Rim Prairie and Barrens (subset) & CES202.352 \\
\hline & Eastern Highland Rim Prairie and Barrens (subset) & CES202.354 \\
\hline & Pennyroyal Karst Plain Prairie and Barrens (subset) & CES202.355 \\
\hline & Central Interior Highlands Calcareous Glade and Barrens (subset) & CES202.691 \\
\hline & Southern Ridge and Valley Calcareous Glade and Woodland (subset) & CES202.024 \\
\hline & Alabama Ketona Glade and Woodland & CES202.338 \\
\hline Mid-Appalachian shale barrens & Appalachian Shale Barrens & CES202.598 \\
\hline \multirow[t]{3}{*}{ High-elevation outcrops and balds } & Southern Appalachian Grass and Shrub Bald & CES202.294 \\
\hline & Southern Appalachian Granitic Dome (subset) & CES202.297 \\
\hline & Southern Appalachian Rocky Summit (subset) & CES202.327 \\
\hline \multirow[t]{2}{*}{ Carolina bays } & Atlantic Coastal Plain Clay-Based Carolina Bay Wetland & CES203.245 \\
\hline & Atlantic Coastal Plain Peatland Pocosin and Canebrake (subset) & CES203.267 \\
\hline \multirow[t]{3}{*}{ Karst-depression wetlands } & Central Interior Highlands and Appalachian Sinkhole and Depression Pond & CES202.018 \\
\hline & East Gulf Coastal Plain Depression Pond (subset) & CES203.558 \\
\hline & Southern Atlantic Coastal Plain Depression Pond (subset) & CES203.262 \\
\hline \multirow[t]{7}{*}{ Riverscour ecosystems } & Cumberland Riverscour & CES202.036 \\
\hline & Southern Piedmont Small Floodplain and Riparian Forest (subset) & CES202.323 \\
\hline & Southern Piedmont Large Floodplain Forest (subset) & CES202.324 \\
\hline & Central Appalachian River Floodplain (subset) & CES202.608 \\
\hline & Central Appalachian Stream and Riparian (subset) & CES202.609 \\
\hline & South-Central Interior Large Floodplain Forest (subset) & CES202.705 \\
\hline & South-Central Interior Small Stream and Riparian (subset) & CES202.706 \\
\hline
\end{tabular}




\section{Appendix 2. Component Associations According to the International Terrestrial Ecological Systems Classification}

Ecological systems are coarse-level categories under the International Terrestrial Ecological Systems Classification (ITESC). For each ecological system, component plant associations are finer-scale categories (NatureServe, 2003). For each of the ecosystem categories described in the preceding chapters, table $2-1$ lists selected plant associations of conservation concern based on the ITESC. Component associations are included if they are ranked as critically imperiled globally (G1), imperiled globally (G2), or vulnerable globally (G3), according to NatureServe (2015).

Table 2-1. Selected plant associations of conservation concern in insular ecosystems of the southeastern United States, with association names and identifiers from the International Terrestrial Ecological Systems Classification (ITESC).

[G1, critically imperiled globally; G2, imperiled globally; G3, vulnerable globally; all rankings G1-G3 are based on NatureServe (2015)]

\begin{tabular}{cll}
\hline \multicolumn{1}{c|}{ Ecological system } & \multicolumn{1}{c}{ ITESC association name } & ITESC ID \\
\hline Piedmont granite outcrops & Virginia Piedmont Granitic Flatrock Glade (G2) & CEGL003857 \\
& Pine/Granitic Flatrock Border Woodland (G3) & CEGL003993 \\
& Granite Flatrock Complex, Perennial Zone (G3) & CEGL004298 \\
& Piedmont Granitic Flatrock Glade, Seasonal Pool (G1) & CEGL004342 \\
& Piedmont Granitic Flatrock Glade, Annual Succulent Zone (G3) & CEGL004344 \\
\hline Limestone cedar glades & Nashville Basin Post Oak Woodland (G2) & CEGL003712 \\
& Red-cedar-Blue Ash Limestone Woodland (G3) & CEGL003754 \\
& Southern Limestone Glade Margin Shrubland (G3) & CEGL003938 \\
& Limestone Seep Glade (G2) & CEGL004169 \\
& Limestone Glade Streamside Meadow (G2) & CEGL004292 \\
& Limestone Annual Grass Glade (G3) & CEGL004340 \\
& Interior Low Plateaus Limestone Glade Ephemeral Pool (G3) & CEGL004346 \\
& Kentucky Glade Seep (G3) & CEGL004669 \\
& Central Limestone Glade (G2) & CEGL005131 \\
& Outer Bluegrass Dolomite Glade (G1) & CEGL007772 \\
& Chinkapin Oak-Ash/Little Bluestem Woodland (G3) & CEGL002143 \\
& Ozark Limestone Glade (G2) & CEGL002251 \\
& Ozark Dolomite Glade (G3) & CEGL002398 \\
Dry Coosa Valley Barrens (G1) & CEGL004045 \\
Highland Rim Dry-Mesic Prairie (G1) & CEGL004063 \\
& Post Oak-White Oak Dry-Mesic Barrens (G1) & CEGL004217 \\
& Southern Ridge and Valley Annual Grass Glade (G2) & CEGL004339 \\
& Interior Low Plateaus Limestone Glade Ephemeral Pool (G3) & CEGL004346
\end{tabular}


Table 2-1. Selected plant associations of conservation concern in insular ecosystems of the southeastern United States, with association names and identifiers from the International Terrestrial Ecological Systems Classification (ITESC).-Continued

[G1, critically imperiled globally; G2, imperiled globally; G3, vulnerable globally; all rankings G1-G3 are based on NatureServe (2015)]

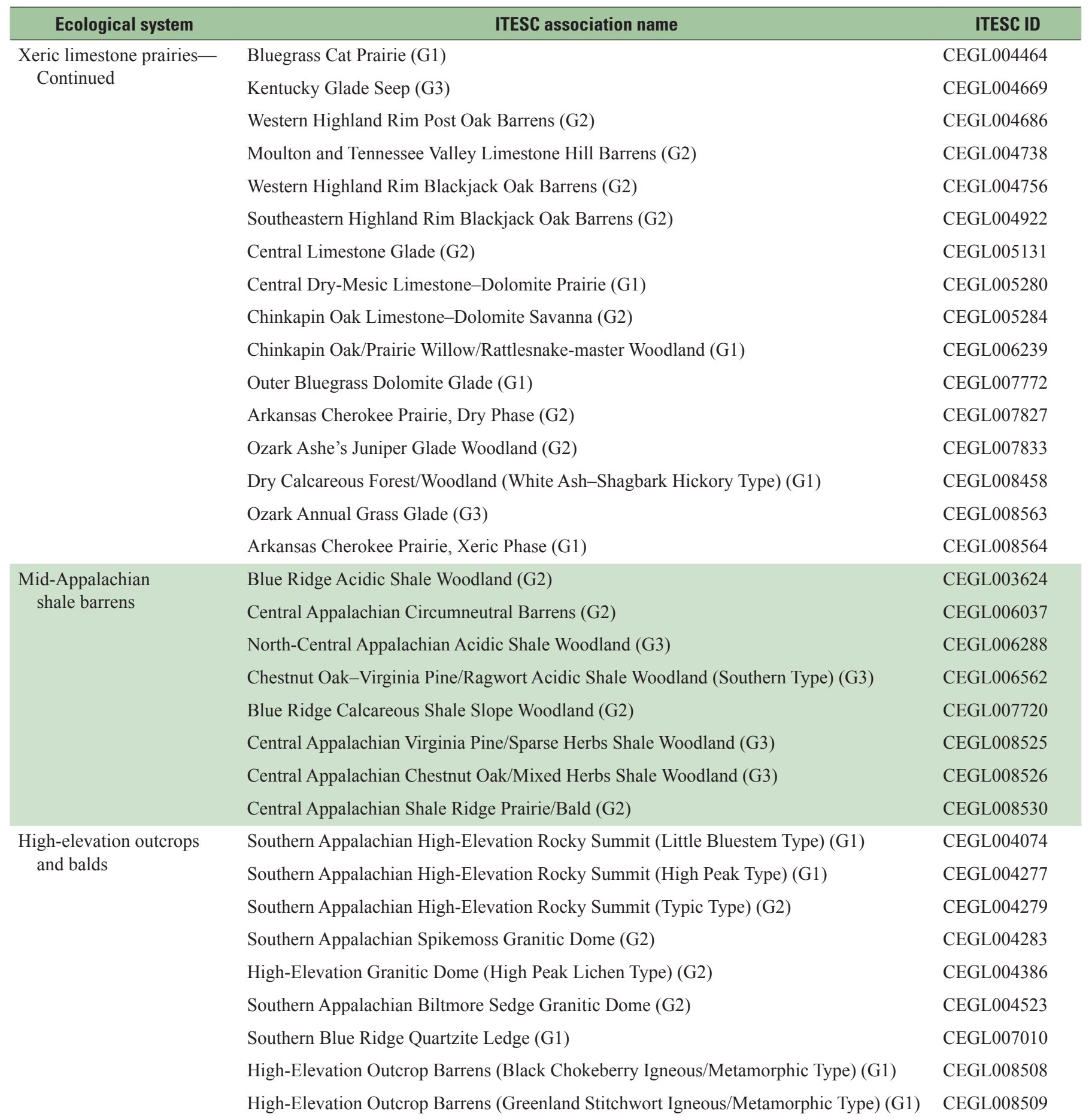


Table 2-1. Selected plant associations of conservation concern in insular ecosystems of the southeastern United States, with association names and identifiers from the International Terrestrial Ecological Systems Classification (ITESC).-C Continued

[G1, critically imperiled globally; G2, imperiled globally; G3, vulnerable globally; all rankings G1-G3 are based on NatureServe (2015)]

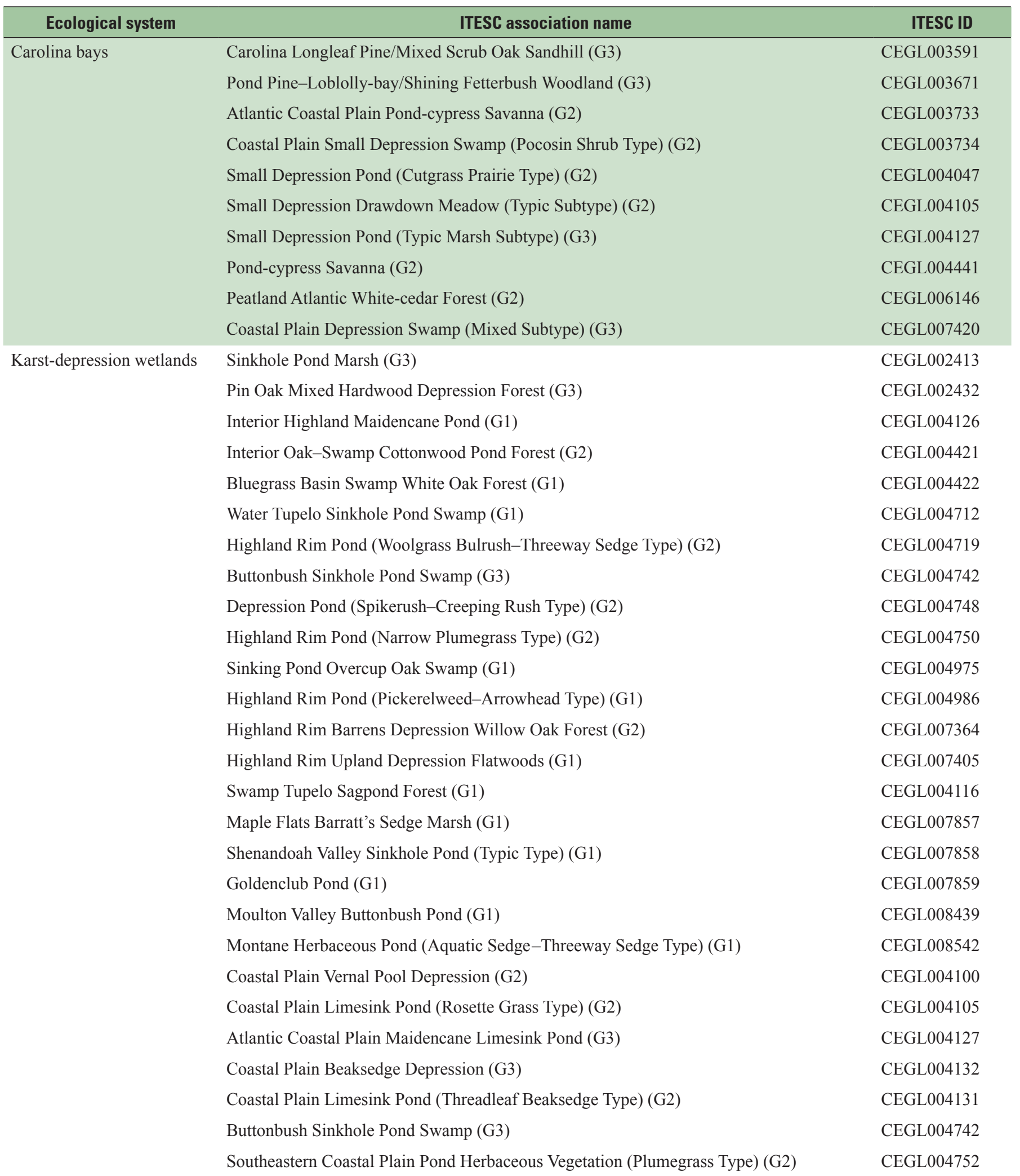


Table 2-1. Selected plant associations of conservation concern in insular ecosystems of the southeastern United States, with association names and identifiers from the International Terrestrial Ecological Systems Classification (ITESC).—Continued

[G1, critically imperiled globally; G2, imperiled globally; G3, vulnerable globally; all rankings G1-G3 are based on NatureServe (2015)]

\begin{tabular}{|c|c|c|}
\hline Ecological system & ITESC association name & ITESC ID \\
\hline \multirow{26}{*}{ Riverscour ecosystems } & Appalachian/Cumberland Sycamore-Birch Riverscour Woodland (G3) & CEGL003725 \\
\hline & Rocky Bar and Shore (Alder-Yellowroot Type) (G3) & CEGL003895 \\
\hline & Riverside Rock Outcrop and Prairie Complex (G3) & CEGL004033 \\
\hline & Rocky Bar and Shore (Twisted Sedge Type) (G3) & CEGL004103 \\
\hline & Cahaba Riverwash Prairie (G1) & CEGL004149 \\
\hline & Rocky-shoal Spiderlily-American Water-willow Herbaceous Vegetation (G1) & CEGL004285 \\
\hline & Eel-grass River Channel (G3) & CEGL004333 \\
\hline & Yadkin River Mafic Scour Prairie (G1) & CEGL004459 \\
\hline & Duck River Scour Prairie (G2) & CEGL004739 \\
\hline & Midwestern Brush Prairie Gravel Wash (G2) & CEGL005175 \\
\hline & River Birch Low Floodplain Forest (G3) & CEGL006184 \\
\hline & Piedmont/Central Appalachian River-Scour Woodland (G1) & CEGL006218 \\
\hline & Fall-line Riverwash Bedrock Prairie (G3) & CEGL006283 \\
\hline & Central Appalachian/Piedmont Bedrock Floodplain Woodland (G2) & CEGL006476 \\
\hline & Ridge and Valley Gravel-Wash Prairie (G2) & CEGL006477 \\
\hline & Piedmont/Central Appalachian Riverside Outcrop Prairie (G1) & CEGL006478 \\
\hline & Piedmont Riverscour Shrubland (G1) & CEGL006484 \\
\hline & Potomac Gorge Riverside Outcrop Barrens (G2) & CEGL006491 \\
\hline & Acidic Sandstone Appalachian Rivershore Prairie (G2) & CEGL006623 \\
\hline & Appalachian/Northern Piedmont Riverside Outcrop Woodland (G1) & CEGL008449 \\
\hline & Hiwassee/Ocoee River Boulder Scour Vegetation (G2) & CEGL008455 \\
\hline & Cumberland Riverside Scour Prairie (G2) & CEGL008471 \\
\hline & $\begin{array}{l}\text { Bushy St. John's-wort-Hazel Alder/Alabama Warbonnet-Tennessee } \\
\text { Yellow-eyed-grass Shrubland (G1) }\end{array}$ & CEGL008494 \\
\hline & Alabama St. John's-wort-Alder Shrubland (G1) & CEGL008495 \\
\hline & Hiwassee/Ocoee Bedrock Scour Vegetation (G2) & CEGL008496 \\
\hline & Barbara's-buttons Riverscour Prairie (G1) & CEGL006598 \\
\hline
\end{tabular}




\section{Appendix 3. Selected Plant Taxa of Conservation Concern in Insular Ecosystems of the Southeastern United States}

Tables 3-1 through 3-8 list selected globally rare plant taxa that have been documented in the insular ecosystems described in the preceding chapters. Scientific names are in accordance with those used by NatureServe (2015). Naming revisions, reclassifications, synonyms, and basionyms are available in the International Plant Names Index (2015), the Integrated Taxonomic Information System (2015), and Natural Resources Conservation Service (2015).

As discussed in the preceding chapters, consensus lists of endemic and biogeographically disjunct taxa are generally lacking for these ecosystems. Thus, notations of endemic and disjunct taxa in these tables are based on a preponderance of evidence from the cited publications. Conservation status information is based on global rankings by NatureServe (2015). For details on methodology for conservation status ranking assignments, see Faber-Langendoen and others (2012). In cases where conservation status ranks were uncertain or straddled two rankings (for example, a G3/G2 listed species), the more conservative (lower numbered) status ranking was used (G2 in this example).

Table 3-1. Selected plant taxa of conservation concern in Piedmont granite outcrops.

[All global rankings are based on NatureServe (2015). Species names denoted by * indicate recent reclassifications (Mason Brock, Austin Peay State University, written commun., 2015). Reference: 1, Shure (1999); 2, Burbanck and Platt (1964); 3, McVaugh (1943); 4, Belden and others (2003); 5, Baskin and Baskin (1988); 6, Wyatt and Fowler (1977); 7, Spaulding (2013); 8, Quarterman and others (1993); 9, Matthews and Murdy (1969). Endemic/disjunct: D, biogeographic disjunctionindicating that occurrences within this ecosystem are disjunct from primary ranges in other regions or represent substantial range expansions (see Brown and others,1996); E, endemic taxa primarily restricted to the ecosystem (see Estill and Cruzan, 2001); NE, near-endemic (primarily restricted to this ecosystem and to related ecosystems in similar contexts); —, not endemic or disjunct. Conservation status: G1, critically imperiled globally; G2, imperiled globally; G3, vulnerable globally; LE, listed as endangered under the U.S. Endangered Species Act; LT, listed as threatened under the U.S. Endangered Species Act]

\begin{tabular}{llll}
\hline \multicolumn{1}{c}{ Species name } & \multicolumn{1}{c}{ Reference } & Endemic/disjunct & Conservation status \\
\hline Amphianthus pusillus* & $1,2,3,8$ & $\mathrm{E}$ & $\mathrm{G} 2, \mathrm{LT}$ \\
Cuscuta harperi & 7 & $\mathrm{NE}$ & $\mathrm{G} 2$ \\
Cyperus granitophilus & $1,2,3,4,5,8$ & $\mathrm{E}$ & $\mathrm{G} 3$ \\
Draba aprica* & 8 & $\mathrm{D}$ & $\mathrm{G} 3$ \\
Isoetes melanospora & $1,3,6,8,9$ & $\mathrm{E}$ & $\mathrm{G} 1, \mathrm{LE}$ \\
Isoetes tegetiformans & $1,8,9$ & $\mathrm{E}$ & $\mathrm{G} 1, \mathrm{LE}$ \\
Portulaca smallii & $1,2,3,4,6,8$ & $\mathrm{E}$ & $\mathrm{G} 3$ \\
Pycnanthemum curvipes & & - & $\mathrm{G} 3$ \\
Quercus georgiana & $1,3,8$ & $\mathrm{E}$ & $\mathrm{G} 3$ \\
Rhus michauxii & & - & $\mathrm{G} 2, \mathrm{LE}$ \\
Rhynchospora saxicola & 1,3 & $\mathrm{NE}$ & $\mathrm{G} 3$ \\
Sedum pusillum & $1,3,6,8$ & $\mathrm{E}$ & $\mathrm{G} 3$ \\
Talinum mengesii & 5 & $\mathrm{NE}$ & $\mathrm{G} 3$ \\
\hline
\end{tabular}


Table 3-2. Selected plant taxa of conservation concern in limestone cedar glades.

[All global rankings are based on NatureServe (2015). Sub-species or variety; names denoted by * indicate recent reclassifications (Mason Brock, Austin Peay State University, written commun., 2015). Reference: 1, Quarterman (1950); 2, Baskin and others (1968); 3, Baskin and Baskin (1989); 4, Baskin and Baskin (1999); 5, Quarterman and others (1993); 6, Baskin and Baskin (2003). Endemic disjunct: E, endemic taxa primarily restricted to the ecosystem (see Estill and Cruzan, 2001); NE, near-endemic (primarily restricted to this ecosystem and to related ecosystems in similar contexts); NE (LG/XLP), near endemic (primarily restricted to limestone cedar glades and xeric limestone prairies); - , not endemic or disjunct. Conservation status: G1, critically imperiled globally; G2, imperiled globally; G3, vulnerable globally; LE, listed as endangered under the U.S. Endangered Species Act; LT, listed as threatened under the U.S. Endangered Species Act; PE, proposed endangered under the U.S. Endangered Species Act; PT, proposed threatened under the U.S. Endangered Species Act; T1, critically imperiled sub-species or variety; T3, vulnerable]

\begin{tabular}{llll}
\hline \multicolumn{1}{c}{ Species name } & Reference & Endemic/disjunct & Conservation status \\
\hline Astragalus bibullatus & $3,4,6$ & $\mathrm{E}$ & $\mathrm{G} 1$, LE \\
Astragalus tennesseensis & $2,3,4,5,6$ & $\mathrm{NE}$ & $\mathrm{G} 3$ \\
Dalea foliosa & $1,2,3,4,6$ & $\mathrm{NE}$ & $\mathrm{G} 2$, LE \\
Dalea gattingeri & $1,2,3,4,5,6$ & $\mathrm{NE}$ (LG/XLP) & $\mathrm{G} 3$ \\
Delphinium alabamicum & 4,6 & $\mathrm{E}$ & $\mathrm{G} 2$ \\
Echinacea tennesseensis & $2,3,4,5,6$ & $\mathrm{NE}$ (LG/XLP) & $\mathrm{G} 2$ \\
Leavenworthia alabamica & $2,4,5,6$ & $\mathrm{NE}$ (LG/XLP) & $\mathrm{G} 2$ \\
Leavenworthia crassa & $2,4,5,6$ & $\mathrm{NE}$ & $\mathrm{G} 2$, PE \\
Leavenworthia exigua var. exigua & $2,3,4,5,6$ & $\mathrm{NE}$ (LG/XLP) & $\mathrm{T} 3$ \\
Leavenworthia exigua var. laciniata & $2,4,5,6$ & $\mathrm{NE}$ (LG/XLP) & $\mathrm{T} 1, \mathrm{PT}$ \\
Leavenworthia exigua var. lutea & $2,3,4,5,6$ & $\mathrm{NE}$ (LG/XLP) & $\mathrm{T} 1$ \\
Lesquerella lyrata* & $2,4,6$ & $\mathrm{NE}$ & $\mathrm{G} 1, \mathrm{LT}$ \\
Onosmodium molle ssp. molle* & $2,3,4,5,6$ & $\mathrm{NE}$ (LG/XLP) & $\mathrm{T} 3$ \\
Phacelia dubia var. interior & $2,3,4,6$ & $\mathrm{E}$ & $\mathrm{T} 3$ \\
Phlox bifida ssp. stellaria & 5,6 & - & $\mathrm{T} 3$ \\
Solidago gattingeri & 3,6 & - & $\mathrm{G} 3$ \\
Talinum calcaricum* & $2,3,4,5,6$ & $\mathrm{NE}$ & $\mathrm{G} 3$ \\
Trifolium calcaricum & 4,6 & $\mathrm{NE}$ (LG/XLP) & $\mathrm{G} 1$ \\
\hline
\end{tabular}


Table 3-3. Selected plant taxa of conservation concern in xeric limestone prairies.

[S1l global rankings are based on NatureServe (2015). Species names denoted by * indicate recent reclassifications (Mason Brock, Austin Peay State University, written commun., 2015). Reference: 1, Lawless and others (2006); 2, Allison and Stevens (2001); 3, Nelson and others (2013); 4, Collins and Wieboldt (1992); 5, Webb and others (1997). Endemic/disjunct: E (KDG), endemic to the Ketona dolomite glades of Bibb County, Alabama; NE, near-endemic (primarily restricted to this ecosystem and to related ecosystems in similar contexts); NE (KDG), near-endemic to the Ketona dolomite glades of Bibb County, Alabama; NE (LG/XLP), near endemic (primarily restricted to limestone cedar glades and xeric limestone prairies); - , not endemic or disjunct. Conservation status: C, candidate for listing under the U.S. Endangered Species Act; G1, critically imperiled globally; G2, imperiled globally; G3, vulnerable globally; LE, listed as endangered under the U.S. Endangered Species Act; LT, listed as threatened under the U.S. Endangered Species Act; PT, proposed threatened under the U.S. Endangered Species Act; T1, critically imperiled sub-species or variety; T2, imperiled sub-species or variety; T3, vulnerable sub-species or variety]

\begin{tabular}{|c|c|c|c|}
\hline Species name & Reference & Endemic/disjunct & Conservation status \\
\hline Agalinis auriculata & 3 & - & G3 \\
\hline Arabis georgiana & 2 & - & G1, PT \\
\hline Astragalus tennesseensis & 2 & $\mathrm{NE}$ & G3 \\
\hline Carex juniperorum & 1,3 & - & G3 \\
\hline Castilleja kraliana & 1,2 & $\mathrm{E}(\mathrm{KDG})$ & G2 \\
\hline Coreopsis grandiflora var. inclinata & 1,2 & $\mathrm{E}(\mathrm{KDG})$ & $\mathrm{T} 2$ \\
\hline Croton alabamensis & 2 & - & G3 \\
\hline Dalea cahaba & 1,2 & $\mathrm{E}(\mathrm{KDG})$ & G2 \\
\hline Dalea gattingeri & 3,5 & NE (LG/XLP) & G3 \\
\hline Delphinium treleasei & 1,3 & - & G3 \\
\hline Echinacea paradoxa var. paradoxa & 1,3 & - & G2 \\
\hline Echinacea tennesseensis & 3 & NE (LG/XLP) & G2 \\
\hline Erigeron strigosus var. dolomiticola & 1,2 & $\mathrm{E}(\mathrm{KDG})$ & $\mathrm{T} 2$ \\
\hline Helianthus eggertii & 3 & - & G3 \\
\hline Helianthus smithii & 2 & - & G2 \\
\hline Leavenworthia alabamica & 3,5 & NE (LG/XLP) & G2 \\
\hline Leavenworthia exigua var. exigua & 2,3 & $\mathrm{NE}(\mathrm{LG} / \mathrm{XLP})$ & $\mathrm{T} 3$ \\
\hline Leavenworthia exigua var. laciniata & 3 & NE (LG/XLP) & $\mathrm{T} 1, \mathrm{PT}$ \\
\hline Leavenworthia exigua var. lutea & 3 & NE (LG/XLP) & $\mathrm{T} 1$ \\
\hline Liatris oligocephala & 1,2 & $\mathrm{E}(\mathrm{KDG})$ & G1 \\
\hline Marshallia mohrii & 2 & - & G3, LT \\
\hline Onosmodium decipiens $*$ & 1,2 & $\mathrm{E}(\mathrm{KDG})$ & G2 \\
\hline Onosmodium molle ssp. molle* & $1,3,5$ & NE (LG/XLP) & $\mathrm{T} 3$ \\
\hline Phlox pulchra & 2 & - & $\mathrm{G} 2$ \\
\hline Prenanthes barbata & 3 & - & G3 \\
\hline Scutellaria alabamensis & 2 & NE (KDG) & $\mathrm{G} 2$ \\
\hline Sedum nevii & 2 & - & G3 \\
\hline Silene regia & 2 & - & G3 \\
\hline Silphium glutinosum & 1,2 & $\mathrm{E}(\mathrm{KDG})$ & G2 \\
\hline Silphium pinnatifidum & 3,5 & - & G3 \\
\hline Solanum carolinense var. hirsutum & 2 & - & $\mathrm{T} 1$ \\
\hline Solidago gattingeri & 1,3 & - & G3 \\
\hline Spigelia gentianoides & 1,2 & $\mathrm{E}(\mathrm{KDG})$ & G1, LE \\
\hline Symphyotrichum georgianum & 2 & - & $\mathrm{G} 3, \mathrm{C}$ \\
\hline Talinum calcaricum & 1,3 & $\mathrm{NE}$ & G3 \\
\hline Trifolium calcaricum & 4 & NE (LG/XLP) & G1 \\
\hline
\end{tabular}


Table 3-4. Selected plant taxa of conservation concern in mid-Appalachian shale barrens.

[All global rankings are based on NatureServe (2015). Species names denoted by * indicate recent reclassifications (Mason Brock, Austin Peay State University, written commun., 2015). Reference: 1, Platt (1951); 2, Keener (1983); 3, Artz (1948); 4, Braunschweig and others (1999); 5, Clarkson (1966); 6, U.S. Forest Service (2011). Endemic/disjunct: E, endemic taxa primarily restricted to the ecosystem (see Estill and Cruzan, 2001); NE, near-endemic (primarily restricted to this ecosystem and to related ecosystems in similar contexts). Conservation status: G1, critically imperiled globally; G2, imperiled globally; G3, vulnerable globally; LE, listed as endangered under the U.S. Endangered Species Act]

\begin{tabular}{llcc}
\hline \multicolumn{1}{c}{ Species name } & Reference & Endemic/disjunct & Conservation status \\
\hline Allium oxyphilum & $1,2,4,6$ & $\mathrm{NE}$ & $\mathrm{G} 2$ \\
Arabis serotina* & $1,2,4,5,6$ & $\mathrm{E}$ & $\mathrm{G} 2, \mathrm{LE}$ \\
Clematis coactilis & $1,2,4,6$ & $\mathrm{NE}$ & $\mathrm{G} 3$ \\
Clematis viticaulis & $1,2,3,4,6$ & $\mathrm{E}$ & $\mathrm{G} 1$ \\
Oenothera argillicola & $1,2,3,4,5,6$ & $\mathrm{E}$ & $\mathrm{G} 3$ \\
Phlox buckleyi & $1,2,4,5,6$ & $\mathrm{NE}$ & $\mathrm{G} 2$ \\
Taenidia montana & $1,2,5,6$ & $\mathrm{NE}$ & $\mathrm{G} 3$ \\
Trifolium virginicum & $1,2,3,4,5,6$ & $\mathrm{NE}$ & $\mathrm{G} 3$ \\
\hline
\end{tabular}

Table 3-5. Selected plant taxa of conservation concern in high-elevation outcrops and balds.

[All global rankings are based on NatureServe (2015). Species names denoted by * indicate recent reclassifications (Mason Brock, Austin Peay State University, written commun., 2015). Reference: 1, Wiser (1994); 2, White and Sutter (1999); 3, Wiser and White (1999). Endemic/disjunct: E, endemic taxa primarily restricted to the ecosystem (see Estill and Cruzan, 2001); NE, near-endemic (primarily restricted to this ecosystem and to related ecosystems in similar contexts); 一, not endemic or disjunct. Conservation status: G1, critically imperiled globally; G2, imperiled globally; G3, vulnerable globally LE, listed as endangered under the U.S. Endangered Species Act; LT, listed as threatened under the U.S. Endangered Species Act]

\begin{tabular}{llcl}
\hline \multicolumn{1}{c}{ Species name } & Reference & Endemic/disjunct & Conservation status \\
\hline Abies fraseri & 3 & - & $\mathrm{G} 2$ \\
Calamagrostis cainii & 3 & $\mathrm{E}$ & $\mathrm{G} 1$ \\
Carex biltmoreana & 1,3 & $\mathrm{NE}$ & $\mathrm{G} 3$ \\
Carex misera & $1,2,3$ & $\mathrm{E}$ & $\mathrm{G} 3$ \\
Carex ruthii & 2,3 & - & $\mathrm{G} 3$ \\
Delphinium exaltatum & 2 & - & $\mathrm{G} 3$ \\
Geum geniculatum & 2 & $\mathrm{E}$ & $\mathrm{G} 1$ \\
Geum radiatum & $1,2,3$ & $\mathrm{E}$ & $\mathrm{G} 2, \mathrm{LE}$ \\
Glyceria nubigena & 2,3 & - & $\mathrm{G} 2$ \\
Houstonia purpurea var. montana & $1,2,3$ & $\mathrm{E}$ & $\mathrm{T} 2, \mathrm{LE}$ \\
Hypericum buckleii & 1,3 & $\mathrm{E}$ & $\mathrm{G} 3$ \\
Hypericum graveolens & 2,3 & - & $\mathrm{G} 3$ \\
Hypericum mitchellianum & 2,3 & - & $\mathrm{G} 3$ \\
Krigia montana & $1,2,3$ & $\mathrm{NE}$ & $\mathrm{G} 3$ \\
Liatris helleri & 1,3 & $\mathrm{NE}$ & $\mathrm{G} 2, \mathrm{LT}$ \\
Lilium grayi & 2 & - & $\mathrm{G} 3$ \\
Prenanthes roanensis* & 2,3 & - & $\mathrm{G} 3$ \\
Rhododendron vaseyi & 2,3 & - & $\mathrm{G} 3$ \\
Rugelia nudicaulis & 2,3 & $\mathrm{NE}$ & $\mathrm{G} 3$ \\
Selaginella tortipila* & 1,3 & - & $\mathrm{G} 3$ \\
Packera millefolia $*$ & 1,3 & $\mathrm{E}$ & $\mathrm{G} 2$ \\
Solidago spithamaea & 1,3 & $\mathrm{E}$ & $\mathrm{G} 2, \mathrm{LT}$ \\
Stachys clingmanii & 2 & & $\mathrm{G} 2$ \\
\hline
\end{tabular}


Table 3-6. Selected plant taxa of conservation concern in Carolina bays.

[All global rankings are based on NatureServe (2015). Species names denoted by * indicate recent reclassifications (Mason Brock, Austin Peay State University, written commun., 2015). Reference: 1, De Steven and Toner (1997); 2, South Carolina Department of Natural Resources (1999); 3, NatureServe Explorer Ecological System Comprehensive Report for CES203.245: Atlantic Coastal Plain Clay-Based Carolina Bay Wetland (NatureServe, 2015); 4, Bennett and Nelson (1991). Endemic/disjunct: NE, near-endemic (primarily restricted to this ecosystem and to related ecosystems in similar contexts); - , not endemic or disjunct. Conservation status: C, candidate for listing under the U.S. Endangered Species Act; G1, critically imperiled globally; G2, imperiled globally; G3, vulnerable globally; LE, listed as endangered under the U.S. Endangered Species Act;]

\begin{tabular}{llcc}
\hline \multicolumn{1}{c}{ Species name } & Reference & Endemic/disjunct & Conservation status \\
\hline Coreopsis rosea & $1,2,3$ & - & $\mathrm{G} 3$ \\
Croton elliottii & 1,3 & - & $\mathrm{G} 2$ \\
Dichanthelium hirstii & 3 & - & $\mathrm{G} 1, \mathrm{C}$ \\
Dionaea muscipula & 2,4 & - & $\mathrm{G} 3$ \\
Echinodorus parvulus & $2,3,4$ & - & $\mathrm{G} 3$ \\
Eupatorium paludicola & 3 & - & $\mathrm{G} 2$ \\
Hypericum harperi & $2,3,4$ & - & $\mathrm{G} 3$ \\
Lindera melissifolia & 3 & - & $\mathrm{G} 2, \mathrm{LE}$ \\
Litsea aestivalis & $2,3,4$ & - & $\mathrm{G} 3$ \\
Lobelia boykinii & $2,3,4$ & - & $\mathrm{G} 2$ \\
Ludwigia spathulata & $1,3,4$ & - & $\mathrm{G} 2$ \\
Myriophyllum laxum & 3 & - & $\mathrm{G} 3$ \\
Oxypolis canbyi & $1,2,3,4$ & $\mathrm{NE}$ & $\mathrm{G} 2, \mathrm{LE}$ \\
Peltandra sagittifolia & $2,3,4$ & - & $\mathrm{G} 3$ \\
Polygonum hirsutum & 3 & - & $\mathrm{G} 3$ \\
Rhexia aristosa & $1,2,3,4$ & - & $\mathrm{G} 3$ \\
\hline
\end{tabular}


Table 3-7. Selected plant taxa of conservation concern in karst-depression wetlands of the Interior Low Plateaus, Shenandoah Valley region of the Valley and Ridge, and the Dougherty Plain.

[All global rankings are based on NatureServe (2015). Reference: 1, Homoya and Hedge (1985). Reference: 2, Fleming and Van Alstine (1999); 3, Buhlmann and others (1999); 4, Sutter and Kral (1994). Region: DP, Dougherty Plain; ILP, Interior Low Plateaus; VR, Shenandoah Valley region of the Valley and Ridge. Endemic/disjunct: D, occurrences within this ecosystem are disjunct from primary ranges in other regions or represent substantial range expansions (see Brown and others, 1996); E, endemic taxa primarily restricted to the ecosystem (see Estill and Cruzan, 2001); NE, near-endemic (primarily restricted to this ecosystem and to related ecosystems in similar contexts); - , not endemic or disjunct. Conservation status: G1, critically imperiled globally; G2, imperiled globally; G3, vulnerable globally; LT, listed as threatened under the U.S. Endangered Species Act]

\begin{tabular}{lcccc}
\hline \multicolumn{1}{c}{ Species name } & Reference & Region & Endemic/disjunct & Conservation status \\
\hline Carex decomposita & 1 & ILP & D & G3 \\
Helenium virginicum & 2,3 & VR & D & G3, LT \\
Helonias bullata & 2,3 & VR & D & G3, LT \\
Hypericum lissophloeus & 4 & DP & E & G2 \\
Isoetes virginica & 2 & VR & NE & G1 \\
Rhexia salicifolia & 4 & DP & NE & G2 \\
Xyris longisepala & 4 & DP & NE & G2 \\
Xyris scabrifolia & 4 & DP & - & G3 \\
\hline
\end{tabular}

Table 3-8. Selected plant taxa of conservation concern in riverscour ecosystems.

[All global rankings are based on NatureServe (2015). Reference: 1, Vanderhorst and others (2007); 2, Vanderhorst and others (2010); 3, Schmalzer (1989); 4, Shaw and Wofford (2003); 5, Taylor (2003); 6, Byers and others (2007); 7, Major and others (1999); 8 , Floden (2012); 9, Campbell and Medley (1989); 10, Schafale (2012); 11, Bailey and Coe (2001); 12, Ogle (1991); 13, Bartgis (1997); 14, Wells (2012). Endemic/disjunct: E, endemic taxa primarily restricted to the ecosystem (see Estill and Cruzan, 2001); NE, nearendemic (primarily restricted to this ecosystem and to related ecosystems in similar contexts); - , not endemic or disjunct. Conservation status: G1, critically imperiled globally; G2, imperiled globally; G3, vulnerable globally; LE, listed as endangered under the U.S. Endangered Species Act; LT, listed as threatened under the U.S. Endangered Species Act]

\begin{tabular}{llcl}
\hline \multicolumn{1}{c}{ Species name } & Reference & Endemic/disjunct & Conservation status \\
\hline Berberis canadensis & 3,4 & - & $\mathrm{G} 3$ \\
Calamovilfa arcuata & $3,4,11$ & $\mathrm{E}$ & $\mathrm{G} 2$ \\
Conradina verticillata & $3,4,5,11$ & $\mathrm{E}$ & $\mathrm{G} 3, \mathrm{LT}$ \\
Eurybia saxicastellii & $5,9,11$ & $\mathrm{E}$ & $\mathrm{G} 1$ \\
Fothergilla major & 4 & - & $\mathrm{G} 3$ \\
Marshallia grandiflora & $2,3,4,5,6,11$ & $\mathrm{NE}$ & $\mathrm{G} 2$ \\
Pityopsis ruthii & 7 & $\mathrm{E}$ & $\mathrm{G} 1, \mathrm{LE}$ \\
Ptilimnium nodosum & 13,14 & $\mathrm{NE}$ & $\mathrm{G} 2, \mathrm{LE}$ \\
Pycnanthemum torrei & 1 & - & $\mathrm{G} 2$ \\
Solidago arenicola & 8 & $\mathrm{E}$ & $\mathrm{G} 2$ \\
Solidago plumosa & 10 & $\mathrm{E}$ & $\mathrm{G} 1$ \\
Spiraea virginiana & $2,3,4,5,11,12$ & $\mathrm{E}$ & $\mathrm{G} 2, \mathrm{LT}$ \\
Vitis rupestris & 1 & $\mathrm{NE}$ & $\mathrm{G} 3$ \\
\hline
\end{tabular}




\section{References Cited in Appendixes}

Allison, J., and Stevens, T., 2001, Vascular flora of Ketona dolomite outcrops in Bibb County, Alabama: Castanea, v. 66 , no. 1, p. $154-205$.

Artz, L., 1948, Plants of the shale barrens of the tributaries of the James River in Virginia: Castanea, v. 13, no. 4, p. 141-145.

Bailey, C., and Coe, F., 2001, The vascular flora of the riparian zones of the Clear Fork River and the New River in the Big South Fork National River and Recreation Area (BSFNRRA): Castanea, v. 66, no. 3, p. 252-274.

Bartgis, R., 1997, The distribution of the endangered plant Ptilimnium nodosum (Rose) Mathias (Apiaceae) in the Potomac River drainage: Castanea, v. 62, no. 1, p. 55-59.

Baskin, J., and Baskin, C., 1988, Endemism in rock outcrop plant communities of unglaciated eastern United StatesAn evaluation of the roles of the edaphic, genetic and light factors: Journal of Biogeography, v. 15, no. 5, p. 829-840.

Baskin, J., and Baskin, C., 1989, Cedar glade endemics in Tennessee, and a review of their autecology: Journal of the Tennessee Academy of Science, v. 64, no. 3, p. 63-74.

Baskin, J., and Baskin, C., 1999, Cedar glades of the southeastern United States, in Anderson, R., Fralish, J., and Baskin, J., eds., Savannas, barrens, and rock outcrop plant communities of North America: New York, Cambridge University Press, p. 206-219.

Baskin, J., and Baskin, C., 2003, The vascular flora of cedar glades of the southeastern United States and its phytogeographical relationships: Journal of the Torrey Botanical Society, v. 130, no. 2, p. 101-118.

Baskin, J., Quarterman, E., and Caudle, C., 1968, Preliminary check-list of the herbaceous vascular plants of cedar glades: Journal of the Tennessee Academy of Science, v. 43, no. 3, p. 65-71.

Belden, A., Chazal, A., and Hobson, C., 2003, A natural heritage inventory of fourteen headwater sites in the Dragon Run Watershed: Richmond, Va., Virginia Department of Conservation and Recreation.

Bennett, S., and Nelson, J., 1991, Distribution and status of Carolina bays in South Carolina: Columbia, S.C., South Carolina Wildlife and Marine Resources Department, Nongame and Heritage Trust Publications, $98 \mathrm{p}$.

Braunschweig, S., Nilson, E., and Wieboldt, T., 1999, The mid-Appalachian shale barrens, in Anderson, R., Fralish, J., and Baskin, J.M., eds., Savannas, barrens, and rock outcrop plant communities of North America: New York, Cambridge University Press, p. 83-98.
Brown, J., Stevens, G., and Kaufman, D., 1996, The geographic range - Size, shape, boundaries, and internal structure: Annual Review of Ecology and Systematics, v. 27 , no. 1996 , p. 597-623.

Buhlmann, K., Mitchell, J., and Smith, L., 1999, Descriptive ecology of the Shenandoah Valley sinkhole pond system in Virginia: Banisteria, v. 13, p. 23-51.

Burbanck, M., and Phillips, D., 1983, Evidence of plant succession on granite outcrops of the Georgia Piedmont: American Midland Naturalist, v. 109, no. 1, p. 94-104.

Burbanck, M., and Platt, R., 1964, Granite outcrop communities of the Piedmont Plateau in Georgia: Ecology, v. 45, no. 2, p. 292-306.

Byers, E., Vanderhorst, J., and Streets, B., 2007, Classification and conservation assessment of high elevation wetland communities in the Allegheny Mountains of West Virginia: Elkins, W. Va., West Virginia Natural Heritage Program.

Campbell, J., and Medley, M., 1989, Aster saxicastellii (Asteraceae), a new species from the Rockcastle River bars in southeastern Kentucky: Sida, v. 13, no. 3, p. 277-284.

Clarkson, R., 1966, The vascular flora of the Monongahela national forest, West Virginia: Castanea, v. 31, no. 1, p. $1-119$.

Collins, J., and Wieboldt, T., 1992, Trifolium calcaricum (Fabaceae), a new clover from limestone barrens of eastern United States: Castanea, v. 57, no. 4, p. 282-286.

De Steven, D., and Toner, M., 1997, Gradient analysis and classification of Carolina bay vegetation - A framework for bay wetlands conservation and restoration: New Ellenton, S.C., U.S. Forest Service, Savannah River Forest Station, $62 \mathrm{p}$.

Estill, J., and Cruzan, M., 2001, Phytogeography of rare plant species endemic to the southeastern United States: Castanea, v. 66, no. 1, p. 3-23.

Faber-Langendoen, D., Nichols, J., Master, L., Snow, K., Tomaino, A., Bittman, R., Hammerson, G., Heidel, B., Ramsay, L., Teucher, A., and Young, B., 2012, NatureServe conservation status assessments-Methodology for assigning ranks: Arlington, Va., NatureServe.

Fleming, G., and Van Alstine, N., 1999, Plant communities and floristic features of sinkhole ponds and seepage wetlands in southeastern Augusta County, Virginia: Banisteria, v. 13 , p. $67-94$.

Floden, A., 2012, Notes on two rare Solidago (Asteraceae) in Tennessee-S. Arenicola and S. simplex: Phytoneuron, v. 63, p. $1-4$. 
Homoya, M., and Hedge, C., 1985, The upland sinkhole swamps and ponds of Harrison County, Indiana: Proceedings of the Indiana Academy of Science, v. 92, p. 383-388.

International Plant Names Index, 2015, The international plant names index, accessed October 5, 2015, at http://www.ipni.org.

Integrated Taxonomic Information System, 2015, The Integrated Taxonomic Information System, accessed October 5, 2015, at http://www.itis.gov.

Keener, C., 1983, Distribution and biohistory of the endemic flora of the mid-Appalachian shale barrens: The Botanical Review, v. 49, no. 1, p. 65-115.

Lawless, P., Baskin, J., and Baskin, C., 2006, Xeric limestone prairies of eastern United States-Review and synthesis: The Botanical Review, v. 72, no. 3, p. 235-272.

Major, C., Bailey, C., Donaldson, J., McCoy, R., Nordman, C., Williams, M., and Withers, D., 1999, An ecological inventory of selected sites in the Cherokee National Forest: Tennessee Department of Environment and Conservation, Tennessee Division of Natural Heritage.

Matthews, J., and Murdy, W., 1969, A study of Isoetes common to the granite outcrops of the southeastern Piedmont, United States: Botanical Gazette, v. 130, no. 1, p. 53-61.

McVaugh, R., 1943, The vegetation of the granitic flat-rocks of the southeastern United States: Ecological Monographs, v. 13 , no. 2, p. 119-166.

Natural Resources Conservation Service, 2015, The USDA plants database: Greensboro, N.C., U.S. Department of Agriculture, Natural Resources Conservation Service, National Plant Data Team, accessed September 25, 2015, at http://plants.usda.gov.

NatureServe, 2003, A working classification of terrestrial ecological systems in the conterminous United StatesInternational terrestrial ecological systems classification: Arlington, Va., NatureServe.

NatureServe, 2015, NatureServe Explorer-An online encyclopedia of life [web application], ver. 7.1, accessed October 7, 2015, at http://www.natureserve.org/explorer.

Nelson, P., Fitzgerald, J., Larson, K., McCoy, R., Schotz, A., Taft, J., Witsell, T., and Yahn, B., 2013, Central hardwoods joint venture glade conservation assessment for the Interior Highlands and Interior Low Plateaus of the central hardwoods region: Central Hardwoods Joint Venture.

Ogle, D., 1991, Spiraea virginiana Britton-II. Ecology and species biology: Castanea, v. 56, no. 4, p. 297-303.

Platt, R., 1951, An ecological study of the mid-Appalachian shale barrens and of the plants endemic to them: Ecological Monographs, v. 21, no. 4, p. 269-300.
Quarterman, E., 1950, Ecology of cedar glades-I. Distribution of glade flora in Tennessee: Bulletin of the Torrey Botanical Club, v. 77, no. 1, p. 1-9.

Quarterman, E., Burbanck, M., and Shure, D., 1993, Rock outcrop communities - Limestone, sandstone, and granite, in Martin, W., Boyce, S., and Echternacht, A., eds., Biodiversity of the southeastern United States-Upland terrestrial communities: New York, John Wiley and Sons, Inc., p. 35-86.

Schafale, M., 2012, Guide to the natural communities of North Carolina, fourth approximation: Raleigh, N.C., North Carolina Natural Heritage Program, 208 p.

Schmalzer, P., 1989, Vegetation and flora of the Obed River gorge system, Cumberland Plateau, Tennessee: Journal of the Tennessee Academy of Science, v. 64, no. 3, p. 161-168.

Shaw, J., and Wofford, B., 2003, Woody plants of Big South Fork National River and Recreation Area, Tennessee and Kentucky and floristic comparison of selected Southern Appalachian woody: Castanea, v. 68, no. 2, p. 119-134.

Shure, D., 1999, Granite outcrops of the southeastern United States., in Anderson, R., Fralish, J., and Baskin, J., eds., Savannas, barrens, and rock outcrop plant communities of North America: New York, Cambridge University Press, p. 99-118.

South Carolina Department of Natural Resources, 1999, Advance identification of Carolina bays for South Carolina wetlands protection: Columbia, S.C., South Carolina Department of Natural Resources, Land, Water and Conservation Division, $46 \mathrm{p}$.

Spaulding, D., 2013, Key to the dodders (Cuscuta, Convolvulaceae) of Alabama and adjacent States: Phytoneuron, v. 74, p. 1-15.

Sutter, R., and Kral, R., 1994, The ecology, status, and conservation of two non-alluvial wetland communities in the south Atlantic and eastern Gulf coastal plain, USA: Biological Conservation, v. 68, p. 235-243.

Taylor, D., 2003, Viability assessment report for riparian habitat association, Daniel Boone National Forest, unpublished report submitted to the National Forest Service, U.S. Department of Agriculture, $19 \mathrm{p}$.

U.S. Forest Service, 2011, Draft environmental impact statement for the revised land and resource management plan, George Washington National Forest: Roanoake, Va., U.S. Department of Agriculture, Forest Service.

Vanderhorst, J.P., Jeuck, J., and Gawler, S.C., 2007, Vegetation classification and mapping of New River Gorge National River, West Virginia: Philadelphia, Pa., U.S. National Park Service, technical report NPS/NER/NRTR—2007/092, $396 \mathrm{p}$. 
Vanderhorst, J., Streets, B., Arcaro, Z., and Gawler, S., 2010, Vegetation classification and mapping of Gauley River National Recreation Area, West Virginia,: Philadelphia, Pa., U.S. National Park Service, technical report NPS/NER/ NRTR—2010/148, 288 p.

Webb, D., DeSelm, H., and Dennis, W., 1997, Studies of prairie barrens of northwestern Alabama: Castanea, v. 62, no. 3 , p. $173-184$.

Wells, E.F., 2012, Seed germination and reproductive strategies in federally endangered Harperella (Harperella nodosum Rose, Apiaceae): Castanea, v. 77, no. 3, p. 218-223.

White, P., and Sutter, R., 1999, Managing biodiversity in historic habitats - Case history of the southern Appalachian grassy balds, in Peine, J., ed., Ecosystem management for sustainability - Principles and practices illustrated by a regional biosphere reserve cooperative: Washington, D.C., Lewis Publishers, p. 375-395.
Wiser, S., 1994, High-elevation cliffs and outcrops of the southern Appalachians - Vascular plants and biogeography: Castanea, v. 59, no. 2, p. 85-116.

Wiser, S., and White, P., 1999, High elevation outcrops and barrens of the southern Appalachian mountains, in Anderson, R., Fralish, J., and Baskin, J., eds., Savannas, barrens, and rock outcrop plant communities of North America: New York, Cambridge University Press, p. 119-132.

Wyatt, R., and Fowler, N., 1977, The vascular flora and vegetation of the North Carolina granite outcrops: Bulletin of the Torrey Botanical Club, v. 104, no. 3, p. 245-253. 
Manuscript approved May 20, 2016

Prepared by the USGS Science Publishing Network Edited by Kimberly A. Waltenbaugh Lafayette Publishing Service Center Illustrations and layout by Caryl J. Wipperfurth Reston Publishing Service Center

For more information concerning this report, please contact:

Director, Lower Mississippi-Gulf Water Science Center U.S. Geological Survey

640 Grassmere Park, Suite 100

Nashville, TN 37211 
